IBOLYA CSENGEL-PLANK*

\title{
BUDAÖRS AIRPORT AND ITS PHOTOMONTAGE - SYMBOLS OF MODERNISM ${ }^{1}$
}

\begin{abstract}
Budaörs Airport is a work of modern architecture built in 1937 in a country that was fundamentally conservative in its political outlook, and was the first public airport in Hungary that met European standards. It was designed by the architects Virgil Bierbauer and László Králik. The airport architecture made use of the lessons learned, both positive and negative, from countless airports in other countries. In this regard it successfully overcame the technical and other problems faced by designers in European countries, which had made it necessary to redesign the airports in these countries in the midthirties. The building was simultaneously modern and pragmatic. Its overhead view, with the side wings attached to the circular passenger hall, clearly shows the purpose of the building. Budaörs Airport was built as a transit airport: it was intended to have an important geopolitical role in connecting air passengers from Central Europe with other countries and continents in the world. In the 1920s, countless airports had been constructed in Europe to deal with air traffic between the different countries and between Europe and their colonies. Hungary, however, had long been excluded from this development, due to the terms of the peace treaties that concluded the First World War. It was not until the mid-1930s that the country had the chance to break free from these restrictions. Budaörs Airport became a symbol both of this newfound liberty and of the start of modern civil aviation, while its creation was also closely linked to the changing lifestyle of the 1920s and 1930s.

The interior of the airport was also designed to meet the expectations of the modern human with an interest in all the new things of the world. The interior decoration of the passenger hall was quite innovative: bearing in mind the philosophical background underlying modern movements in art, it combined the compositional approach of painting (aeropittura, Expressionism) with the techniques of photomontage and murals. This composition, known by the title of "The Experience of Flight," aimed to fill the room with a vision of flight, based partly on realistic and partly on imaginary images, to inspire passengers arriving in the passenger hall, as well as whoever accompanied them. Running all the way around the upstairs balustrade, the enormous photomontage - photofrieze, photomural - was the result of collaboration between the architect Virgil Bierbauer and the painter and photographer Ada Ackermann (Mrs Elemér Marsovszky), and was made using aerial photographs from Hungary and Europe.

By presenting Budaörs Airport in detail, this study is intended as a contribution to investigations into the unique modern architectural world of airport architecture and to the evaluation of the decorative and propagandistic role played by photography.

Keywords: Budapest, Budaörs Airport, airport architecture, waiting room, air traffic, photomontage, photofresco, cyclorama, aerial photography, modernism, modern architecture, modern photography, the architecture periodical Tér és Forma, Virgil Bierbauer (Borbíró), László Králik, Ada Ackermann (Mrs Elemér Marsovszky)
\end{abstract}

\section{INTRODUCTION}

In Hungary, almost at the same time as developments in the rest of Europe, the conditions for constructing a competitive and contemporary civil airport fell

\footnotetext{
* Ibolya Csengel-Plank PhD, photo-historian, Budapest;
} e-mail: icsengelplank@gmail.com into place in the second half of the 1930s. The public airport in Budaörs was fully in line with this period of European airport architecture, and from its official opening - on 20 June 1937 (Fig. 43) - it became a symbol of the return of Hungarian aviation. This was augmented by the modern architectural style of the 


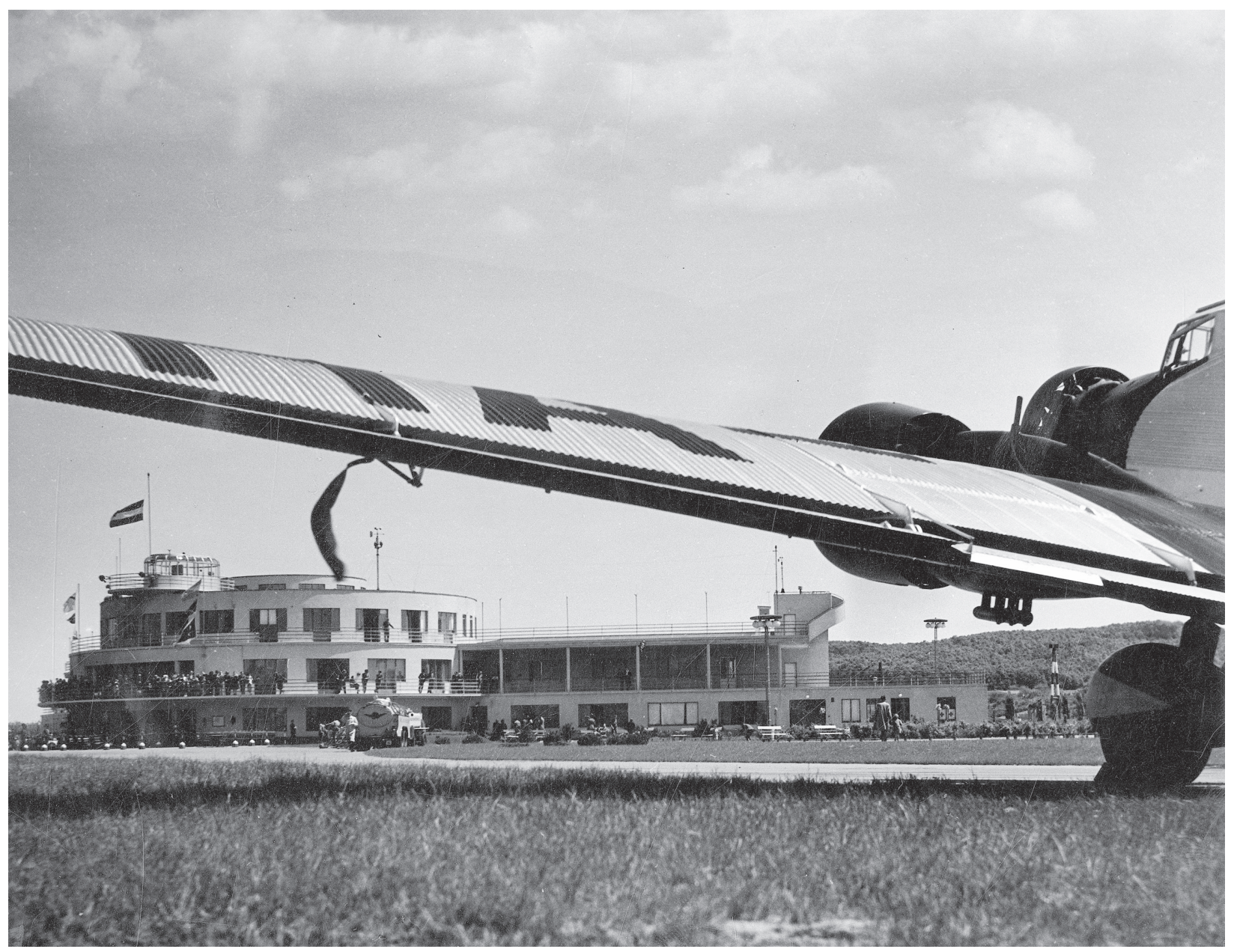

Fig. 1. Budaörs Airport, architects: Virgil Bierbauer and László Králik, 1937 (photo: Rudolf Járay around 1940; FSZEK Budapest Gyüjtemény 030743)

building, its logical internal structure, and its exceptional interior decoration (Figs. 1-3). As far as the latter is concerned, the architects who designed the airport, Virgil Bierbauer (1893-1956) and László Králik (1897-?), made efforts from the very outset to create a unique and spectacular waiting room. The creation of this photographic composition, which is exceptional even by international comparisons, and the way it came about, are as enlightening as the work itself. Its creators were determined to make use of the latest mass media technologies, and the most up-to-date photographic techniques of monumental decoration, in situ photofresco. Having concluded their experiments at the end of 1936, the architects opted for photomontage to perform the role of a mural. Eventually, the balustrade above the top-lit central waiting room was covered with a 44-metre-long cycloramic photomontage. The commission for making the composition, titled "The Experience of Flight" (In Hungarian: "A repülés élménye"), was given to the photographer
Ada Ackermann (Mrs Elemér Marsovszky) (1895-?). Her iconography was based on aerial photographs of cities and landscapes, which were linked together using details from images of heavenly bodies, clouds and a variety of aircraft. The choice of technique also facilitated a certain cinematographic effect, for the interconnections and rhythms of the different components of the cyclorama, arising from the nature of montage, shared affinities with the world of moving pictures. This dramaturgy was necessary because the main objective of the cyclorama was for its imagery to conjure up associations and memories that would take viewers on an internal journey, even before they left the ground. Overall, anyone visiting the airport would have been able to participate in a rarely seen visual experience that was still missing from the everyday emotions of life.

A whole series of mutual effects and contradictions can be discovered in the history of Budaörs Airport and its photomontage. One of the most exciting questions 


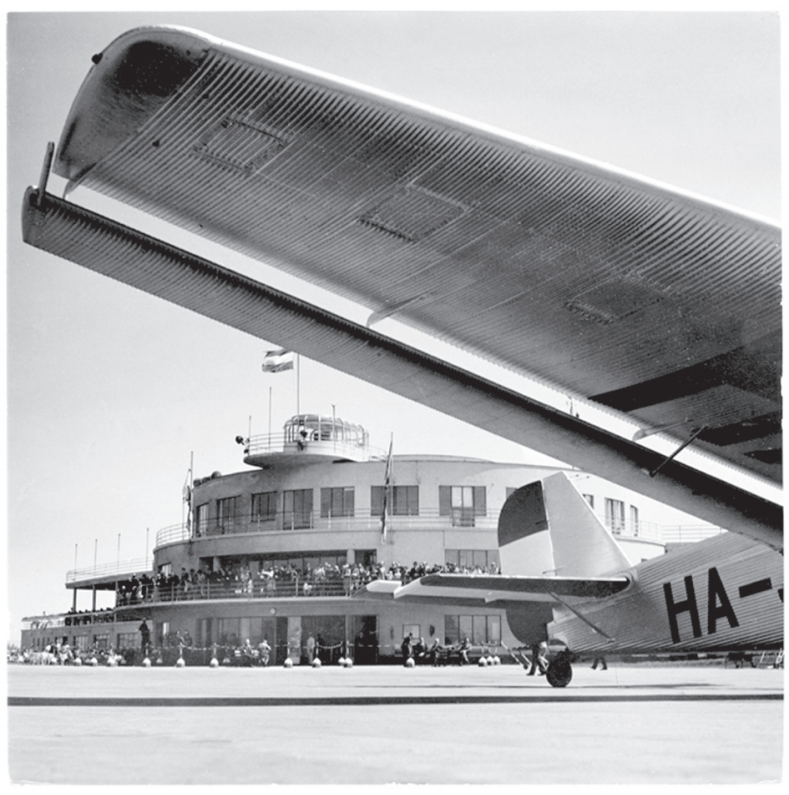

Fig. 2. Budaörs Airport

(photo: Rudolf Járay around 1940;

FSZEK Budapest Gyújtemény) concerned the factors that may have led to the creation of such a modern, avant-garde inspired work of photographic art, whose technique and media were so far away from the traditional artistic forms of national representation. Alongside numerous other factors, it is possible to detect the modern phenomenon of flying in such a close interweaving of architecture and photographic art, as well as creative bravery in elevating the photomontage to equal rank with the architectural space. It was at this time that modern stylistic hallmarks became a common presence in this branch of the arts, and the use of such hallmarks - together with functionalistic thinking - soon proved to have greater strength than national character and manifestations of tried-and-tested patterns. The fact that Hungary could only catch up with international aviation if the architecture also took international trends into consideration was perfectly clear to the people who commissioned Budaörs Airport. In the 1930s in Hungarian society there was a noticeable change in people's attitudes towards modern architecture. Part of this

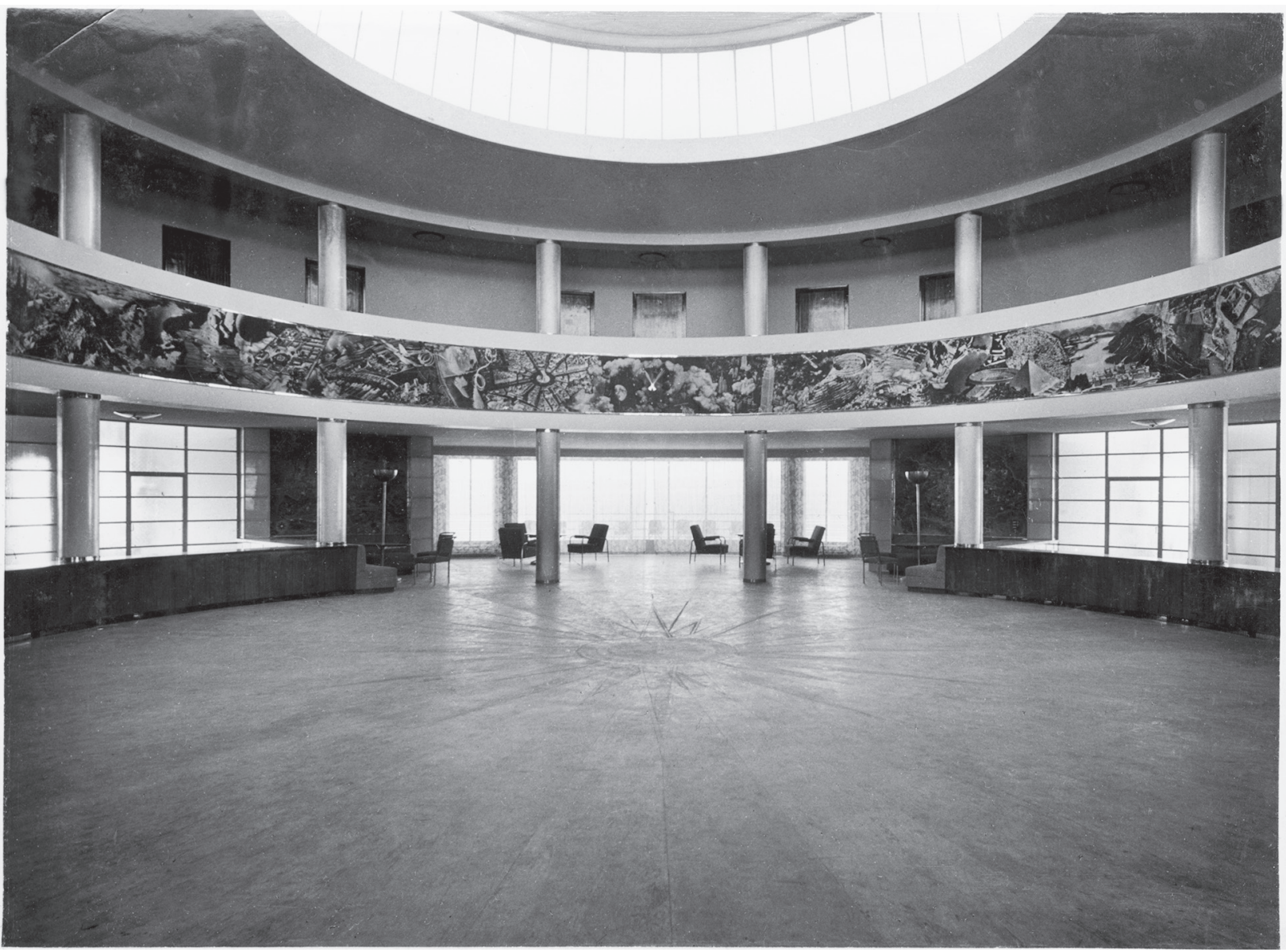

Fig. 3. The waiting room of Budaörs Airport's terminal building, from left to right with the sections XI-XII-I-II-III of the cyclorama "The Experience of Flight"

(photo: Mrs Elemér Marsovszky, Belvárosi Fotómúhely, 1937; MÉM Borbíró-hagyaték GYN: 659. 21. doboz) 
stemmed from the consequences of the global economic depression, which not only intensified social tensions in Hungary, but also broke the monopoly over Hungarian art that had previously been enjoyed by conservatism based on the official Christian nationalist ideology. It was no coincidence that this period first saw the general acceptance in Hungary of modern architecture, advertising design and photography. The first modern shops, department stores and cin- emas were built during these years, and their contemporary forms soon spread to apartment blocks, villas and detached houses. Modern architecture of this kind remained popular in Hungary until 1943. The decorativeness of Budaörs Airport - its flowing shape and ornate interior - demonstrates that, by the time it was built, modern architecture was beginning to move forward from the "muteness" of abstraction and the selfreferential nature of functionalism.

\section{THE DESIGN PROCESS AND ITS ANTECEDENTS}

After 1935, in the area of transport policy, the Hungarian government decided to give priority support to aviation and to tourism. ${ }^{2}$ Despite the fact that, at the time Budapest's new civil airport was built, certain examples and experiences of European airport construction were well known, the negative consequences of the political situation that developed in the wake of the First World War meant that Hungarian air traffic and its facilities were placed at a serious and long-lasting disadvantage. Under the terms of the peace treaty with Hungary (1920) to end the war, the Hungarian air force was dismantled and its entire infrastructure - aircraft, engines, hangars, airports, landing strips was destroyed, together with the entire system of air transport institutions. ${ }^{3}$ Moreover, limits were imposed on the number of airports and hangars that could be maintained for civil air traffic, with just 7-9 airports allowed to operate in the entire country. Of the three airports in Budapest, only those in Aszód and Mátyásföld were allowed to continue operations, and the one in Albertfalva had to close. The first Hungarian air transport company (Magyar Aeroforgalmi Rt., or MAFEORT) was founded in spring 1920. The company was soon wound up by the international inspection committee, after it was discovered that the Hungarian authorities had actually established it as a front organisation for a secret air force whose aim was to save what it could from before. The situation settled somewhat in 1922 when several airlines applied for permits to start flights from Mátyásföld (Figs. 4-5). Among them were two newly established Hungarian airlines, MALERT $^{4}$ and AEROEXPRESZ, ${ }^{5}$ as well as the foreign airlines Imperial Airways, KLM and Deutsch Lufthansa AG. ${ }^{6}$ Although there were many debates about where in the capital it would be located, and implementation seemed to be a problem for the distant future, the idea of building a new international airport to meet the needs of civilian air traffic was soon on the agenda. ${ }^{7}$
The first architectural plans were drawn up in 1924 by the Aviation Authority, for redevelopment of the military training base in Rákos. The global financial crisis, however, meant that the plan was postponed until after 1928. ${ }^{8}$ The opportunities for Hungarian development were also heavily influenced by the position laid out for it in European air transport, because airlines that ran international flights saw Budapest more as a "technical landing site" or simply as a destination than as any kind of "air traffic hub."" This placed Hungary in an especially difficult situation, for in 1933 there were hardly any home-based flights out of the country, and most of these went only to Austria or, with transfer, to Italy. ${ }^{10}$ There was also a lack of international flight paths passing through Budapest in a north-south direction (towards Poland and the Adriatic), and routes further east (to Bucharest) had also still not been established. ${ }^{11}$ The only way out of these problems was to come up with a new geopolitical strategy to influence air traffic development, and rapid improvements in infrastructure to catch up with modern Europe. ${ }^{12}$ One of the greatest dilemmas for Budaörs Airport was that it needed to surpass the level of development that had already been achieved in Western European countries while expressing and implementing everything that had been learnt in its first new building.

When Hungarian aviation began to find its feet again in the interwar period, the aim was to make use of the regional advantages that arose out of the country's central location in Europe, and the new airport was to be given a central role in this. However, behind the strategy to develop civil aviation there was probably also a secret military agenda right from the start. Grounds for thinking this lie in the fact that the years in which the airport was designed and built - 1935-1937 - coincided with the period when revisionist diplomatic preparations were being made. This was when it became clear that, in the ring of "little 


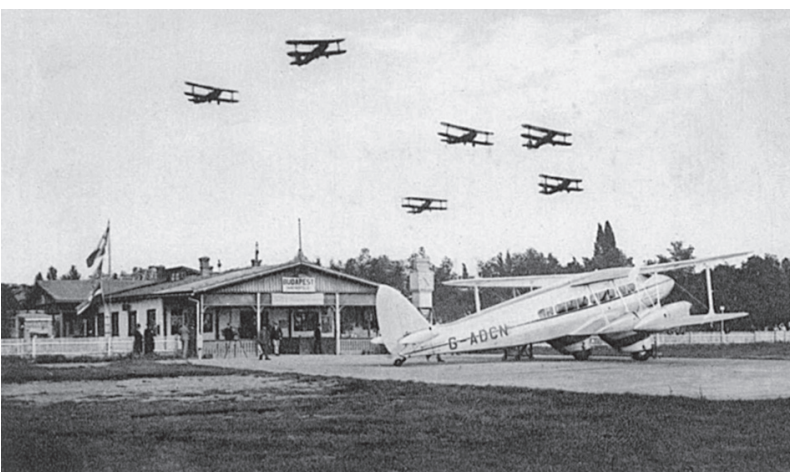

Fig. 4. Mátyásföld Airport in the 1920s (postcard; KHGy, Budapest XVI)

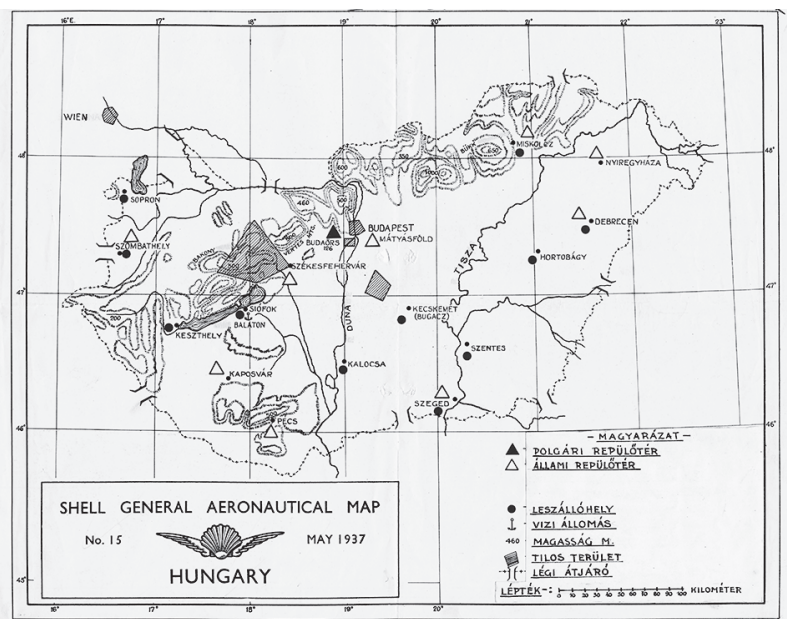

Fig. 5. A map of Hungary's airports. Shell General Aeronautical Map, May 1937, Hungary (A supplement to Shell Aviation News Number 76. October 1937)

entente" countries surrounding Hungary, the nation would only be able to achieve its revisionist aims concerning the territories lost in the First World War if it could count on the support of Italy and Germany. The programmes of military and civil aviation were only separated from one another after the Bled Conference of 23 August 1938, which finally ended the internationally illegal nature of Hungarian aviation. ${ }^{13}$

Seen from the historical perspective of the postTrianon period, for a country that had lost almost two thirds of its pre-war territory, any achievement that was capable in any way or form of serving state representation or national ideology, whether directly or indirectly, could be regarded as a question of status and prestige. Creating an international airport in the capital of Hungary that could be developed into a European air transport hub thanks to its geographical and regional characteristics became an important part of the national ideology (Fig. 6). Géza Bornemisza, minister of trade and transport, wrote the following lines on the subject in 1937: "In order to maintain and fulfil this historical role in the sphere of air transport, it was indispensable to replace the airport in Mátyásföld, the scene of the first attempts to take flight, with a new airport that in every respect complies with modern technical requirements, which will attract air traffic from every point of the compass...". ${ }^{14}$ Besides the transport policy aspects, the construction of Budaörs Airport also represented an enormous architectural challenge: all over the world, the construction of modern airports was a new task for architects to grapple with, and after a period of searching and experimentation in the 1920s, airport architecture finally broke away from international style trends and architectural precedents that recalled railway termini and headed in its own new direction.

Within a short time, the elegant and modern hallmarks of international airports, recognisable from afar, had been established, and these complexes, created out of a diversity of interests and demands, were transformed into transit stations that offered a wealth of visual experiences and entertainment opportunities. The need to popularise the idea of flying was satisfied in the design of elegant observation areas, terraces, and glasslined waiting rooms, from where visitors had pleasant views over the runways and the surrounding scenery. Murals, mosaics and other artworks were designed not only as decoration, but also as propaganda, raising interest in air travel, and abstractly helping to assuage people's fears about flying.

This period also promised tremendous opportunities for foreign travel and air tourism, and the reconstruction and modernisation of Le Bourget airport next to Paris, redesigned by the architect Georges Labro, took place to coincide with the Exposition Universelle of 1937.

\subsection{The call for architectural designs}

After 1929 Hungarian aviation circles turned their attention ever more intensively to questions concerning airport construction, and from the publications released by those who participated in foreign study trips it was already possible to piece together the technical regulations and standards that were coming into being when foreign airports were built. ${ }^{15}$ Some experts also made comparisons between different types of passenger areas and dealt with the modern aesthetics of airports. In 1931, the importance of flight was underlined to the Hungarian general public and its 
politicians by the first successful transatlantic flight by Hungarian pilots, on board a plane called "Justice for Hungary"16 (Fig. 6), and the arrival in Budapest of the airship Graf Zeppelin (Fig. 7). The scandal surrounding the visit by the airship also gave new motivation to the question of a new airport, because in the absence of a suitable landing site, the airship was forced to land in the private airfield of the Manfréd Weiss factory in Csepel (Csepeli Weiss Manfréd Gyár).

The location of Budaörs Airport was only decided after lengthy debates and complex negotiations. The final decision was made by politicians, but it was shaped not only by involving military and aviation experts, but also by consulting public opinion via the press. As the old airport in Mátyásföld was in such an unsuitable condition - unattractive main building, complete lack of comfort, difficult to access ${ }^{17}-$, the government decided in 1934 that a new airport should be built. Several locations were proposed, ${ }^{18}$ and in March 1935 the final choice was an ideally placed, empty plot of land near Budaörs, just west of Budapest (the present-day address is: Budapest, 11th district, Kőérberki Way 36). ${ }^{19}$

When the location was finally chosen, the call for architectural designs for Budaörs Airport could be issued. The first call for theoretical designs was announced in 1934 by the Hungarian Union of Engineers and Architects, ${ }^{20}$ and after the site in Budaörs was finalised, the Ministry of Industry issued an open invitation for designs on 12 February $1936 .{ }^{21}$ Thirtyfive designs were received by the deadline of 31 March, and the joint ministerial committee in charge of assessing the bids ${ }^{22}$ voted by simple majority on the ranking of the four best applicants: László Czakó (1861-?), László Králik, István Bándy (?-?) and János Wanner (1906-1988). A further eleven submissions were singled out for merit, and offers were made to purchase four of them. ${ }^{23}$ The ministers in the end commissioned Virgil Bierbauer and László Králik to execute the planning permission drawings by combining their concepts as one. The body announcing the call for designs laid out three principles for designing the airport: the terminal building must meet contemporary requirements, the budget must be low, and it must in every respect be "original and Hungarian." 24 Implementing the "original and Hungarian" character, clearly a question of style, was perhaps the hardest of the principles to tackle. The experiences amassed from the foreign study trips that preceded the call for designs showed that a modern airport could only be successful if it was built in accordance with international trends, using all

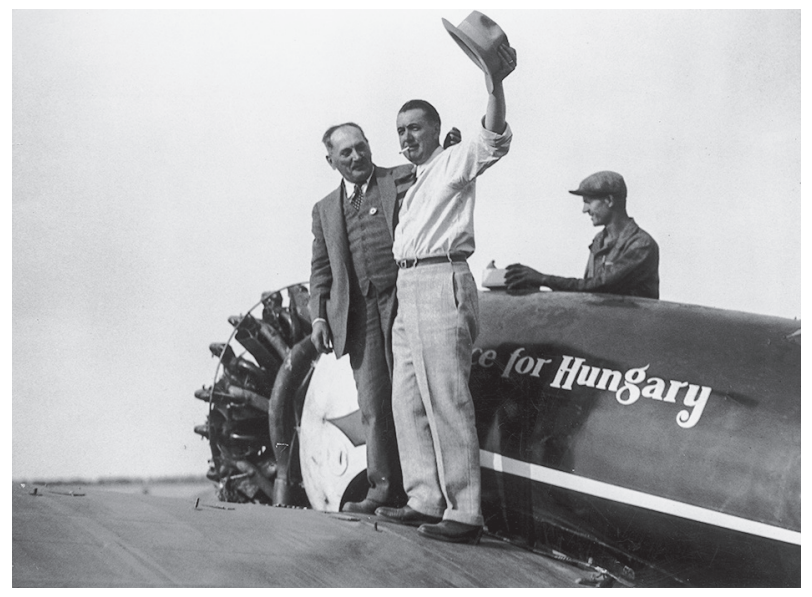

Fig. 6. The aeroplane of the first Hungarian transatlantic flyers named "Justice for Hungary" at its landing on 16 July 1931 (photo: BTM F.72.1802.35)

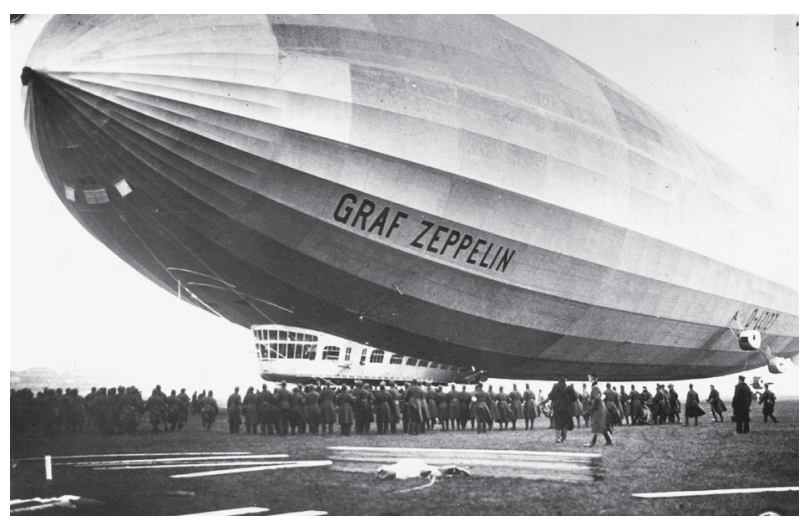

Fig. 7. The arrival of the airship Graf Zeppelin at the private airfield of the Manfred Weiss Works in Csepel on 29 March 1931 (photo: Fortepan 41712)

the technical knowledge and organising principles that had been developed thus far. This implied that a national style would not necessarily be compatible with these requirements. As Bierbauer wrote, "If there is one type of building which was conceived solely out of the needs of the present day, and which can only assume the image of our times, then it is definitely the airport building. [...] Just as aviation exploded into our lives without any ancestry, and is the same age as we are, the buildings associated with aviation can only grow from our own world, our own view of the world and our architectural knowledge." 25 Dominika Vámos classifies Budaörs airport - together with some other industrial or technical constructions - among the buildings in Hungary that reflect the Italian influence, primarily due to the elegant solutions that are incorporated into functional requirements. ${ }^{26}$ The problem of reconciling the traditional national style with modernity was not confined to Hungary, however, and Bierbauer also found the solution abroad. Research carried 


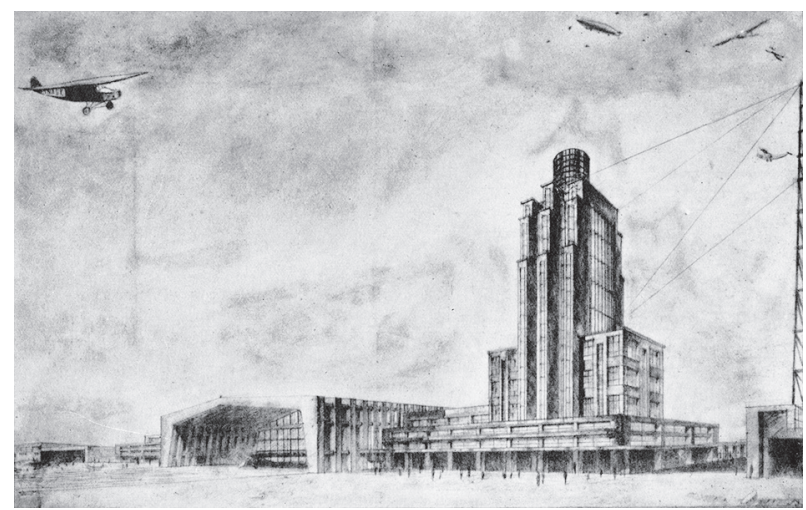

Fig. 8. Jenó Faludi's plan for the Rome Airport, 1927 (Tér és Forma 1. 1928. 2. 153

out by Zsuzsa Ordasi shows that Bierbauer took his lead from contemporary Italian architecture, which provided him with the answer of how to make a work of architecture that preserved national traditions while being simultaneously European and modern. ${ }^{27}$

One characteristic example of how these problems were dealt with can be seen in the design for the airport in Rome produced in 1927 by Eugenio (originally Jenô) Faludi (Fig. 8), the Hungarian-born leader of the Italian architectural group, Gruppo Urbanisti Romani. His design was first presented at the $4^{\text {th }}$ International Conference on Aerial Navigation, ${ }^{28}$ and was subsequently published in the Hungarian architectural periodical Tér és Forma ("Space and Form"), in 1928. ${ }^{29}$ Judging from the illustrations, Faludi placed ground-floor wing buildings on two sides of the central hangar, for the public and for offices; ${ }^{30}$ above one of them he conceived a twelve-storey tower, forty metres in height, with a divided façade. At night, this would serve both as a lighthouse and as an astronomical observatory, while it would also be a radio and observation station, and certain units would be there to cater for passengers. For the public there was a hall, a buffet, a waiting room, an information centre and a ticket office, as well as hotel rooms for transfer passengers. The central tower building, representing modernity, recalled the appearance of skyscrapers, which was more a reflection of luxury than serving actual functional needs. Despite the fact that Faludi's design ranked ahead of the buildings for Tempelhof and Le Bourget (1), in terms of both size and technical equipment, his ideas were never built.

Italy also provides us with an interesting parallel for the connection between politics and architecture. Whereas Mussolini's fascist cultural policy, which favoured Italian rationalist architecture, officially supported modern monumental trends in architecture, ${ }^{31}$ in Hungary at the same time modern architecture received no state support at all, and did not even feature in state policy. In the absence of state commissions, the social programme of modern architects virtually disappeared, and it is partly for this reason that the majority of people in Hungary who commissioned villas and other buildings in a modern style came from the upper middle classes. ${ }^{32}$ After 1948, as the communist regime took hold of Hungary, monumental art was elevated to the rank of state art and architecture, both in the formation of interiors and in the decoration of buildings. Trends in architectural decoration after 1948 followed two directions. On the one hand, attempts were made to move away from the modern - "cosmopolitan," "formalist," "constructivist" - approach, but on the other hand, the public buildings erected in subsequent decades (cultural palaces, railway stations, institutions for health and education, ministry buildings), as well as other public spaces, were adorned with monumental murals and sculptures that symbolised the dawn of a new period of community art. ${ }^{33}$ The spread of extremely large artworks was connected to the political propaganda of the one-party system, of course, whose aim was to use all the tools available to support their ideology, similarly to the practice pursued by every dictatorial and autocratic regime of the twentieth century.

\section{VIRGIL BIERBAUER}

\subsection{Highlights from the career of Virgil Bierbauer}

Virgil Bierbauer (during World War II he changed his name to the more Hungarian-sounding Borbíró) (Nagyenyed [Aiud, Romania], 6 March 1893 - Budapest, 25 July 1956) came from a family of architects (Figs. 9-10). He began his engineering studies in Munich in 1911, ${ }^{34}$ graduating initially with a degree in architectural engineering in 1915,35 before earning an engineering PhD in $1920 .{ }^{36}$ At university he attended lectures by Heinrich Wölfflin, among others. His father, István Bierbauer, was head of the buildings directorate for the Hungarian Postal Service, while his elder sister, Clarisse Bierbauer (?-?), made a name for herself in modern movement art. Virgil Bierbauer was demobilised from the army in November 1918, after 


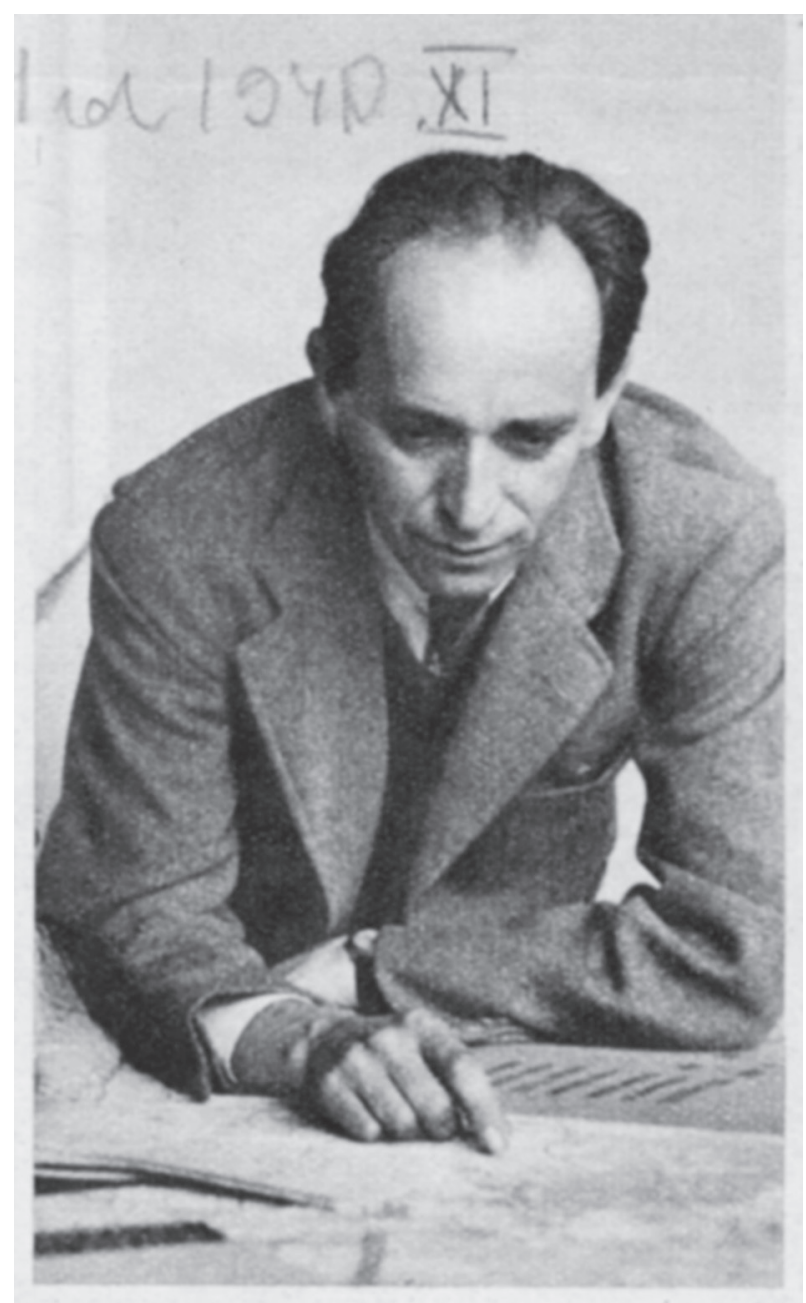

Fig. 9. Virgil Bierbauer's portrait

(photo from the 1930s: MÉM Borbíró-hagyaték GYN: 659)

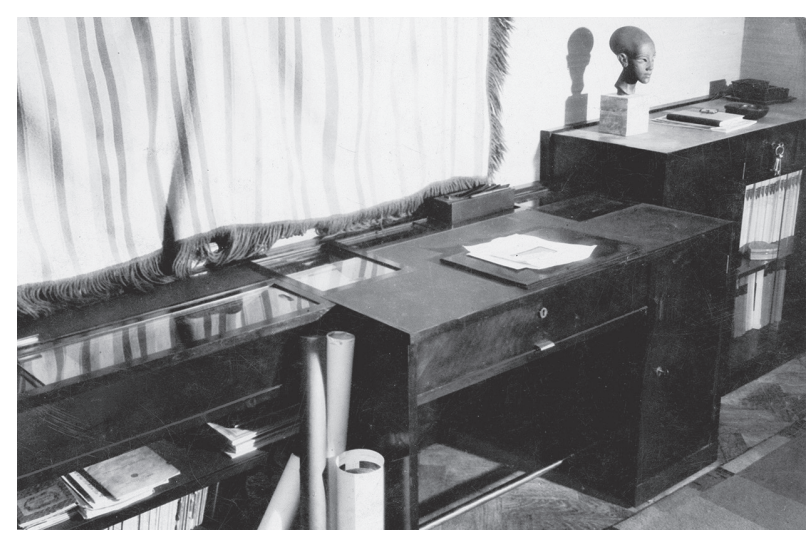

Fig. 10. Virgil Bierbauer's desk

(photo from the 1930s: MÉM Borbíró-hagyaték GYN: 659)

which he joined the National Ministerial Commission for Housing, although by 1922, when he designed the Grand Hotel in Tihany, he was no longer working for the state. He married Adrienn Graul (1896-1973), a certified art teacher, in 1920 (Fig. 11), and they had

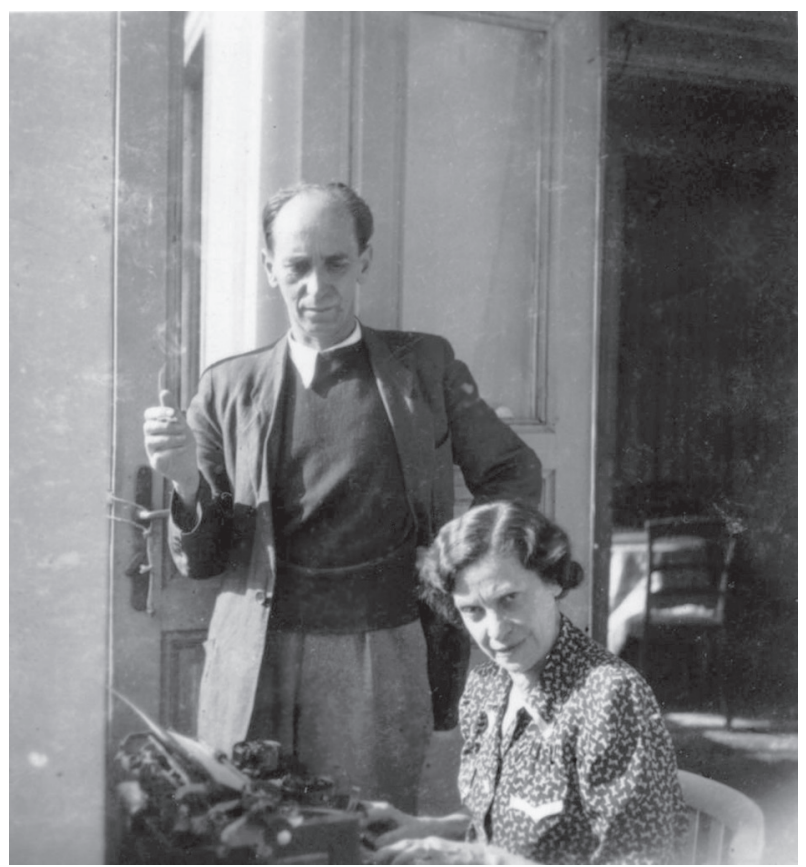

Fig. 11. Virgil Bierbauer and his wife Adrienn Graul (photo from the 1930s: MÉM Borbíró-hagyaték GYN: 659)

two sons. The family had a wide circle of friends from the fields of art and architecture. Virgil Bierbauer is best known for his expansion of the Municipal Electricity Works in Kelenföld (1925-1934; Fig. 12) and for the main building at Budaörs Airport (1936-1937; Figs. 2-3); his most successful exhibition building was the pavilion of the RimamuránySalgótarján Ironworks at the Budapest International Fair (1939-1941; Fig. 13). He worked in collaboration with fellow architects Pál Müller (?-?), Kálmán Reichl (1879-1926) and László Králik. His awareness of what was going on in Europe derived partly from the fact that he had opportunities to see many Western examples of functionalist architecture at first hand in the 1920s. In 1927 he visited Germany and the Netherlands, and while attending the Fifth International Congress of Architects, ${ }^{37}$ he also familiarised himself with the experimental housing estate in Stuttgart, which later served as an analogy for the model estate on Napraforgó Street in the Budapest suburb of Pasarét. In 1928 he travelled to Italy and France, where he made the acquaintance of Le Corbusier and his partner, Pierre Jeanneret. ${ }^{38}$ His later foreign study tours were connected with housing, and in autumn 1929 he attended the Twelfth International Housing and Town Planning Congress in Rome; two years later, he was responsible for organising the Hungarian room at the Housing Exhibition in Berlin. ${ }^{39} 1930$ was a particularly important year in his career, for he was 


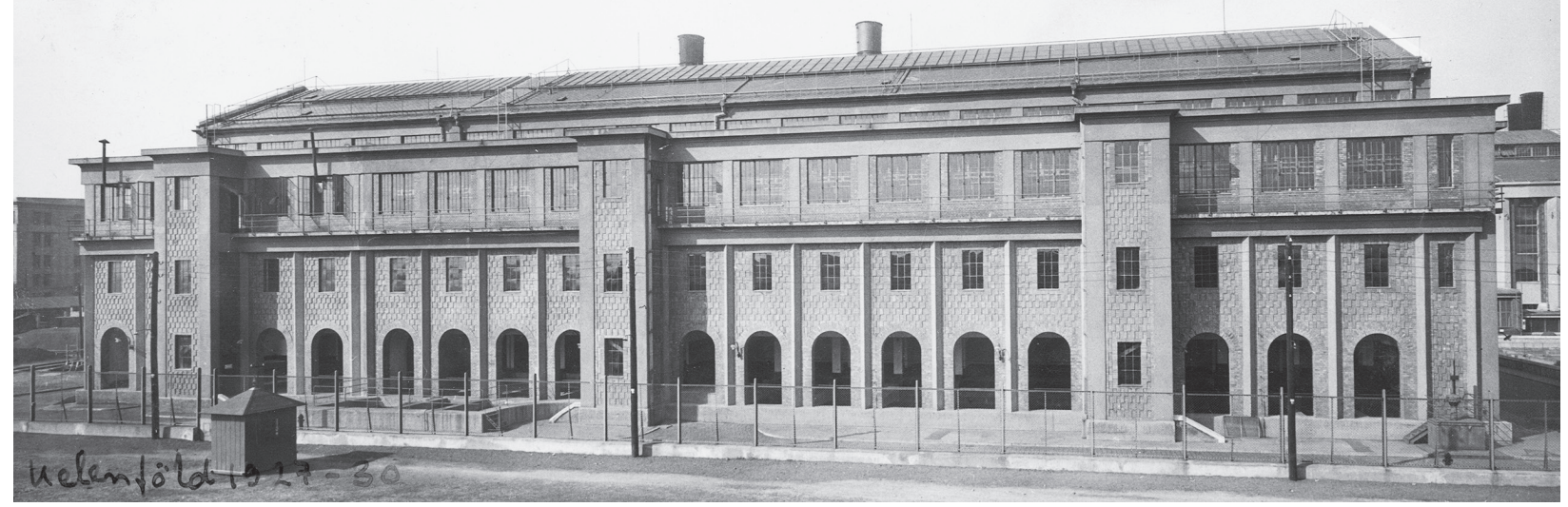

Fig. 12. Power Station in Kelenföld (52 Budafoki Street, 1lth district, Budapest):

the Danube façade of the $30 \mathrm{kV}$ switch center, 1913/1927-1933, architects: Kálmán Reichl and Virgil Bierbauer (photo from 1932; MÉM Borbíró-hagyaték GYN: 659. 22. doboz)

elected an honorary member of the Royal Institute of British Architects (RIBA), in recognition of his work organising the afore-mentioned congress. He maintained links with the Royal Institute, which kept him informed about developments in the world of archi- tecture, and in 1935 it was through the RIBA that he first got in touch with Wells Coates, whose photomural decoration for Embassy Court, a luxury apartment building in Brighton, had caught Bierbauer's eye in a 1931 issue of Architectural Review magazine. ${ }^{40}$

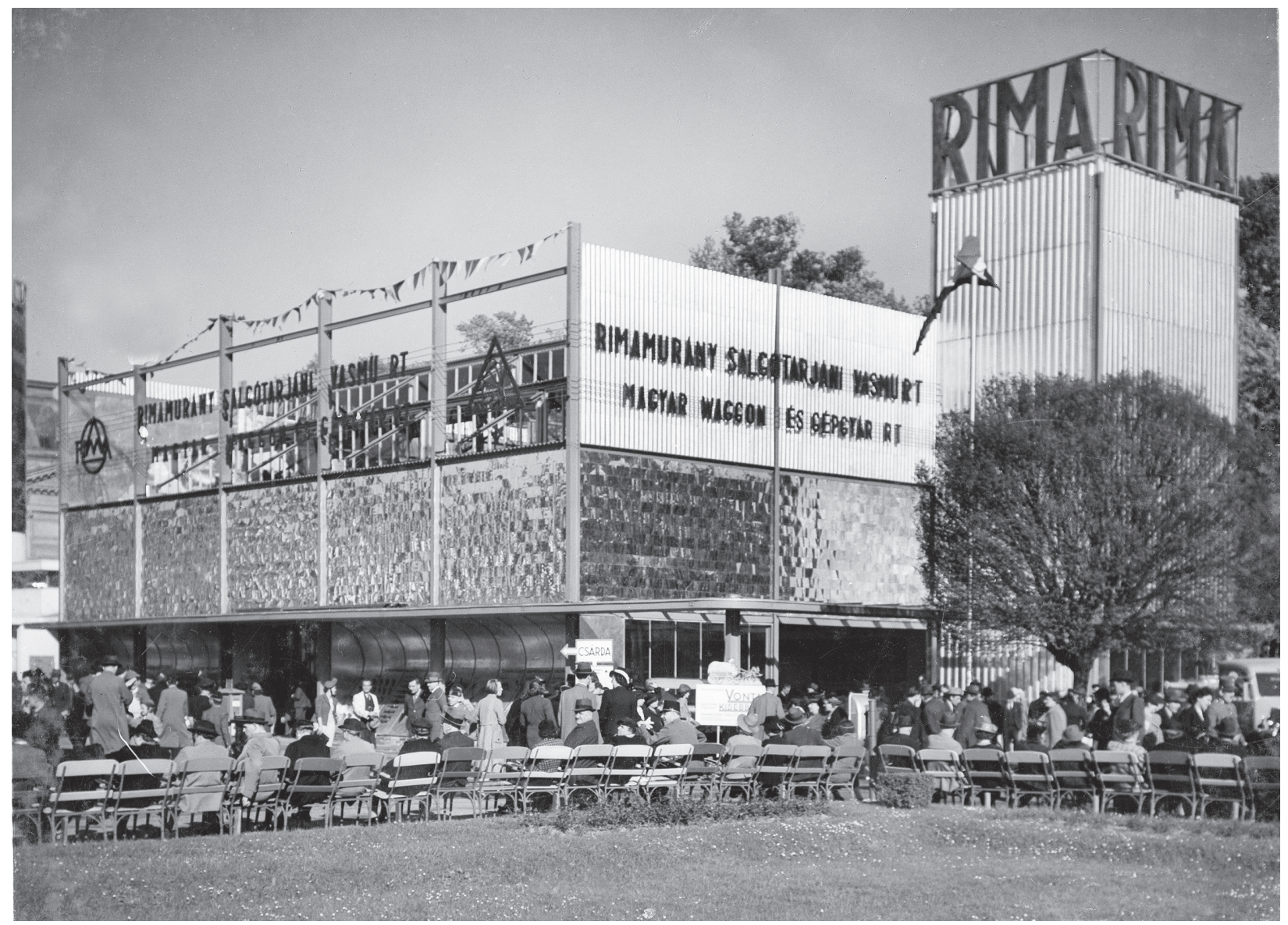

Fig. 13. Pavilion of the Rimamurány-Salgótarján Ironworks at the Budapest International Fair, architect: Virgil Bierbauer, 1939-1941; on the façades montages by Mrs Elemér Marsovszky, 1939 (MÉM Borbíró-hagyaték GYN: 659. 22. doboz) 


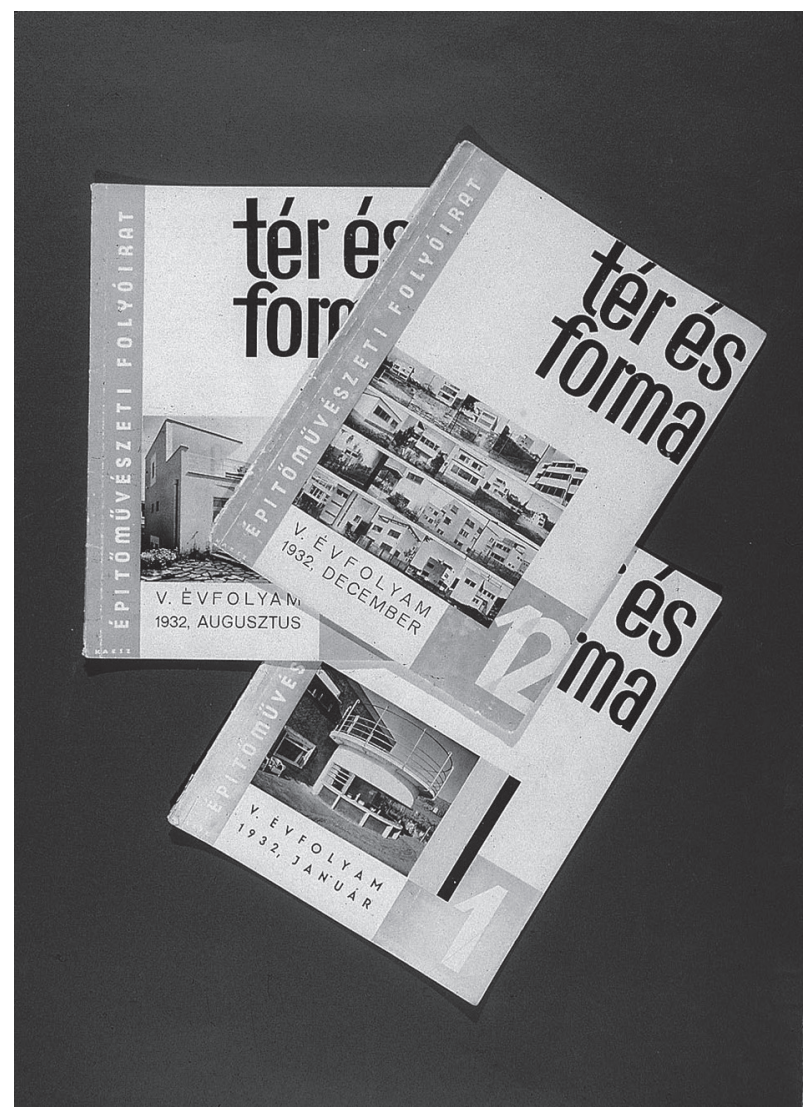

Fig. 14. The architectural journal Tér és Forma, edited by Virgil Bierbauer

At this time Bierbauer was already working on the experimental housing estate in Budapest and on the Electricity Works; he also organised, together with the architect László Nyíri (1902-1955), a travelling architecture exhibition titled "How to Build" ("Hogyan építsünk"). ${ }^{41}$

In addition to his work as an organiser, he also published articles and books on architecture, and as editor-in-chief of a periodical and as a curator of exhibitions, he was constantly on the look-out for new pictures and illustrations. In the field of photography, he published an article on the birth of the photomural, ${ }^{42}$ uniquely in Hungary, where this modern genre had previously been ignored by the press. While he occasionally dabbled in photography himself, he was not alone among architects in entrusting the work of taking on-site photographs to the experts. This was the procedure he followed as editor of the architectural magazine Tér és Forma, which was filled with pictures taken by professional photographers (Fig. 14). Kelenföld Power Station was the only design project of his for which his written study was illustrated with a selection of his own snapshots.

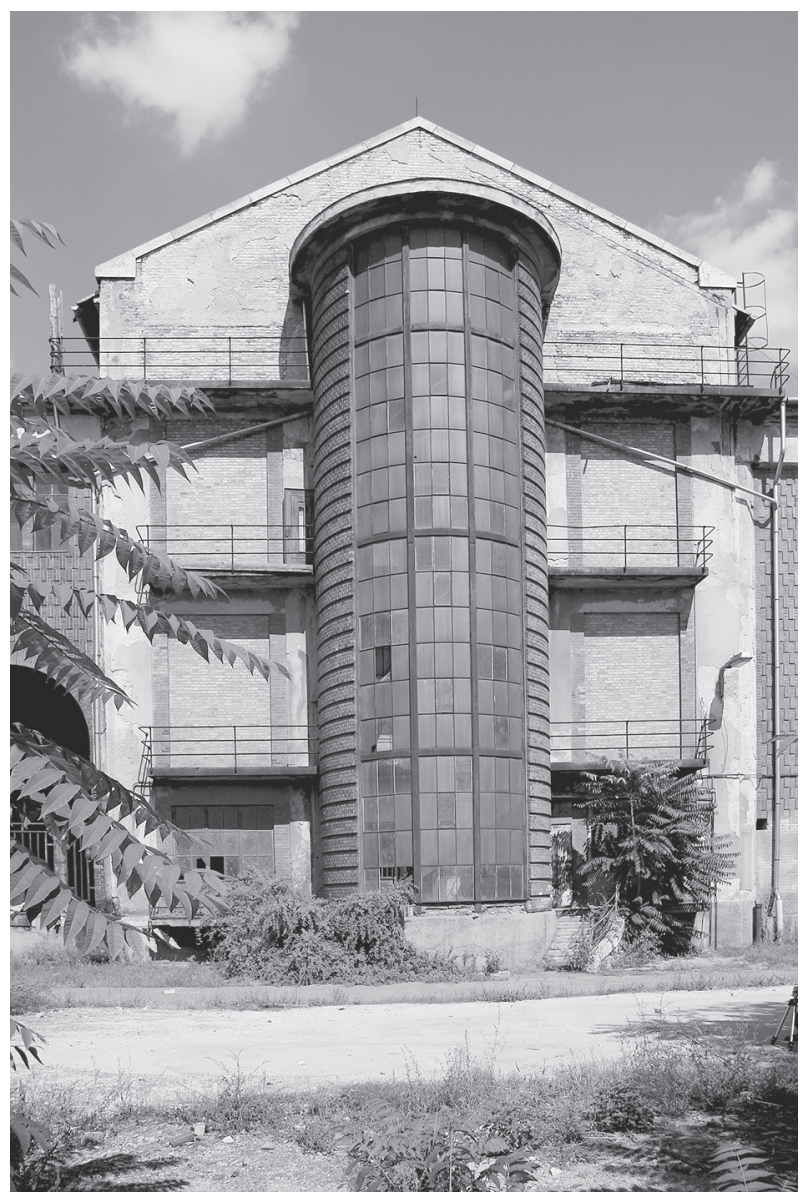

Fig. 15. Kelenföld Power Station, the façade of the $30 \mathrm{kV}$ switch room facing the Danube, architects:

Kálmán Reichl and Virgil Bierbauer, 1913/1927-1933 (photo: Galacánu Efstatia, 2008)

By the 1930s, Bierbauer's name had become synonymous with the editorship of Tér és Forma, which, between 1928 and 1948, was practically the only journal in Hungary that dealt with modern architecture. A significant part of his entire career consisted of raising awareness about architectural matters, and besides his writings on modern architecture, he also dealt with the architecture of homesteads in Hungary and with questions of urban planning. ${ }^{43}$ Between 1945 and 1954 he worked for the Government Commission for Reconstruction, the Ministry of Construction and the Institute for Housing Design.${ }^{44}$ Even after the war, when the communists took power, and throughout the theoretical debates that ensued, he remained true to his convictions regarding modern architecture. One exceptional document that demonstrates this is a manuscript, titled "Ten Letters about Architecture, 1948" ("Tíz levél az építészetrôl 1948"), written under his new Hungarianised name of Borbíró, in which he 


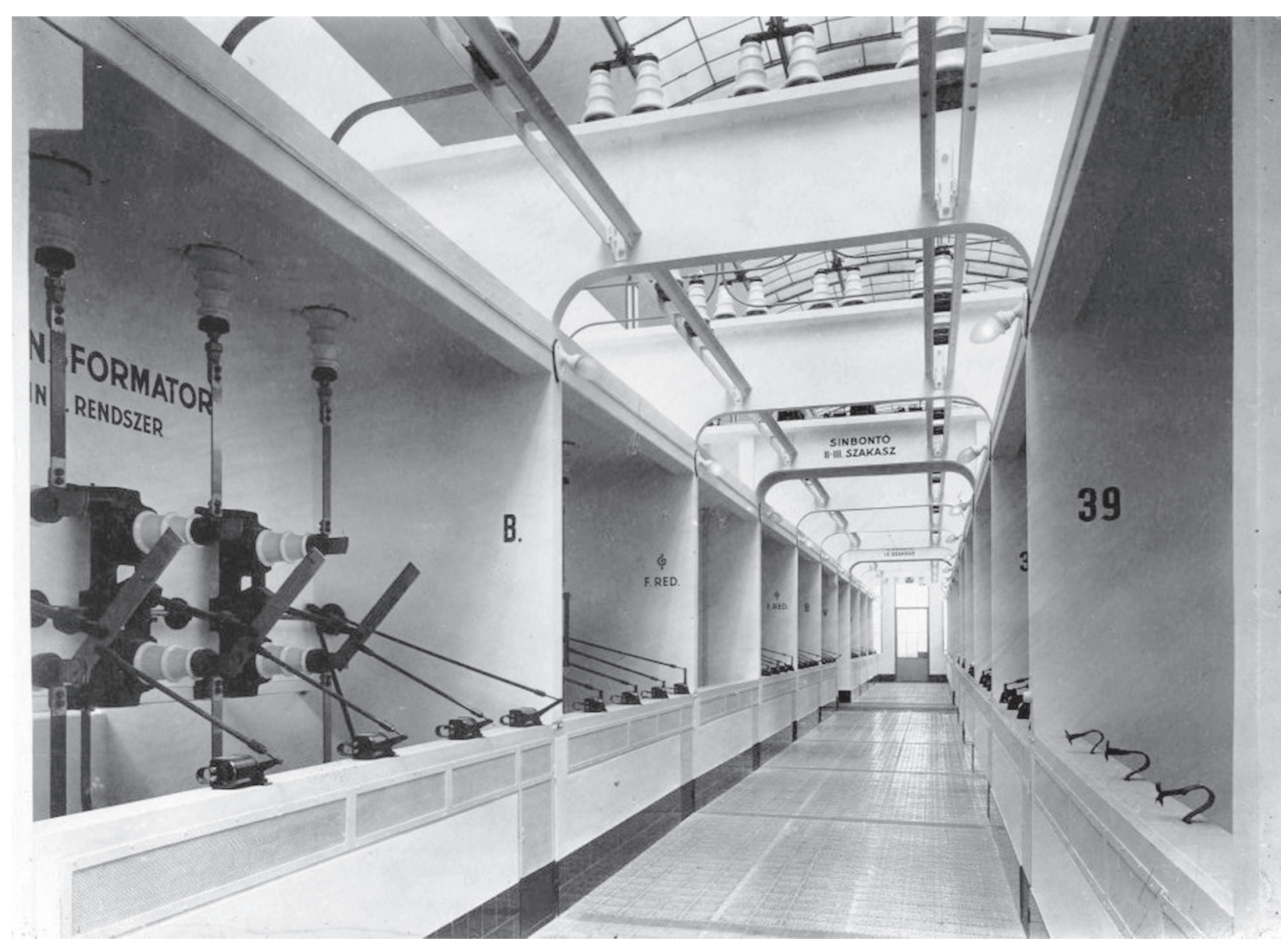

Fig. 16. The basement of Kelenföld Power Station, architects: Kálmán Reichl and Virgil Bierbauer, 1913/1927-1933 (photo: Ernő Bánó, 1933; IPM FLT 24468.4)

summarised his thoughts in the form of open letters to his contemporaries. ${ }^{45}$ In the fourth letter, titled "To a journalist" ("Egy újságíróhoz"), he expounded on the aesthetic opportunities in functionalist architecture using his own airport design as an example, making particular reference to the way rooms are arranged and grouped together. ${ }^{46}$

In 1972, the architect's widow, who was responsible for preserving his estate, completed her processing of her husband's papers, and a large proportion of them, together with the diaries of Mrs Borbíró, were submitted to what was then the Ministry of Food and Agriculture. ${ }^{47}$ The documents give a precise picture of Bierbauer's wide-ranging international contacts, who included Alvar Aalto, Richard Neutra, Marcel Breuer, Walter Gropius, Eliel Saarinen, Alberto Sartoris and Georges Labro. Whereas his foreign connections were made up of the exchange of letters and information, as well as study trips, his relations within Hungary were shaped by profession-related events and social programmes based around his family. The social occasions he attended were frequented by artists as well as architects, and it was partly through this aspect of his life that he became acquainted with the photographer Ada Ackermann (Mrs Elemér Marsovszky). It is our opinion that the idea and concept of the cyclorama played an important role in his career. Every aspect of its implementation was preceded by rigorous and wellconsidered reflection, including consultations with Ada Ackermann, and several design variations. It was no coincidence that Bierbauer - as we have already mentioned - wrote several articles on the history of the photofresco.

During the siege of Budapest in the Second World War, countless documents were lost or destroyed, and there are anecdotes stating that Bierbauer used his blueprints to cover broken windows and keep out the cold in 1945.

All that remains of the original materials used for the cyclorama, apart from the aerial photographs originating from foreign collections and from the Hungarian Institute of Cartography, is a set of 4 laminated photographic maquettes. ${ }^{48}$ 


\subsection{Kelenföld Power Station, built in the modern style}

The design for Kelenföld Power Station (Budapest), specifically boiler room number III, was Bierbauer's first industrial commission. It was here that he first developed his working method of systematically examining specific European precedents of modern industrial architecture before embarking on his own design, a method he would later also employ when preparing his airport design. Construction on the site in Kelenföld began in 1913 under the direction of Kálmán Reichl, and it was after his death in 1925 that Bierbauer joined in the work (Figs. 12, 15), about which his wife noted, "in some parts, the outside had to comply with what had been built in the 1910s, but the inside needed some completely new solutions (e.g. new structural plans, 30,000-volt switch room, etc.)."49 The building for boiler room number III was so filled with enormous boilers and other machines that there was originally space for neither light nor air inside, but Bierbauer placed great emphasis on allowing natural light into both the larger spaces and the corridors ${ }^{50}$
(Fig. 16). He discussed these aspects in a presentation he delivered years later: "The form of the switch room was determined mainly by the need for clarity, good natural light and safety"51 (Figs. 17-18). He also designed other industrial buildings to have increased openness to the light. In Budapest, the switch rooms of the central electrical substation (in the courtyard of the City Hall) and the transformer station on Hungária Boulevard were designed using this approach, ${ }^{52}$ so that all the different displays, ammeters, voltmeters and other instruments would be clearly visible. In the case of Kelenföld Power Station, which supplied the capital with electricity, the building was given a glass dome, and the control room beneath it was fitted with a movable protective roof. In a sign of the tangible military tensions at the time, a small concrete bunker was constructed inside the control room; this was kept secret, and therefore did not feature in photographs of the inside of the building. On the film negatives, however, it is easy to pick out the retouched detail of the bunker as well as the delicate network of lines of the technical switches and panels that were subsequently

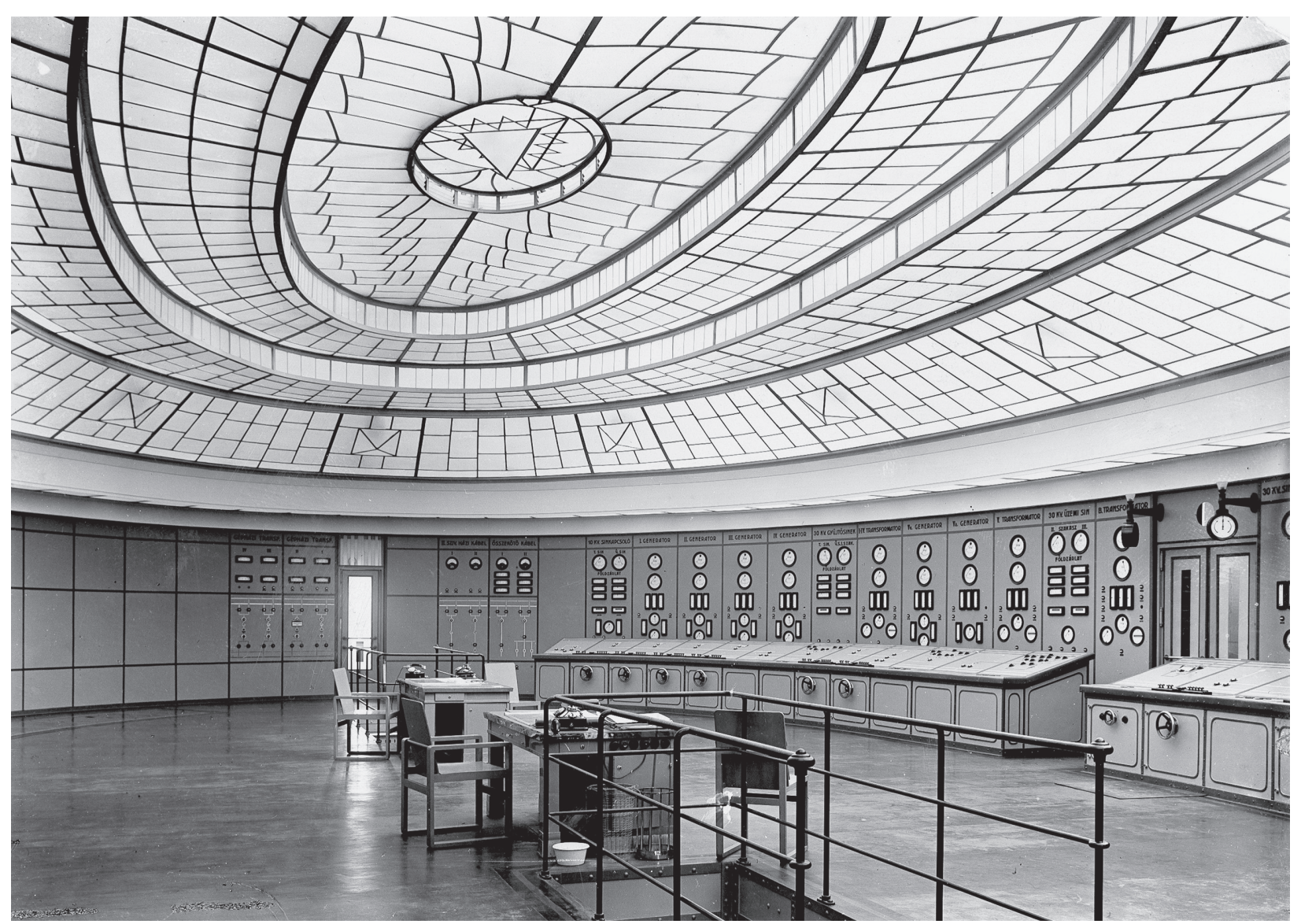

Fig. 17. The control room of Kelenföld Power Station, architect: Virgil Bierbauer, 1927-1933 (photo: Tivadar Kozelka; MÉM Borbíró-hagyaték GYN: 659. 22. doboz) 


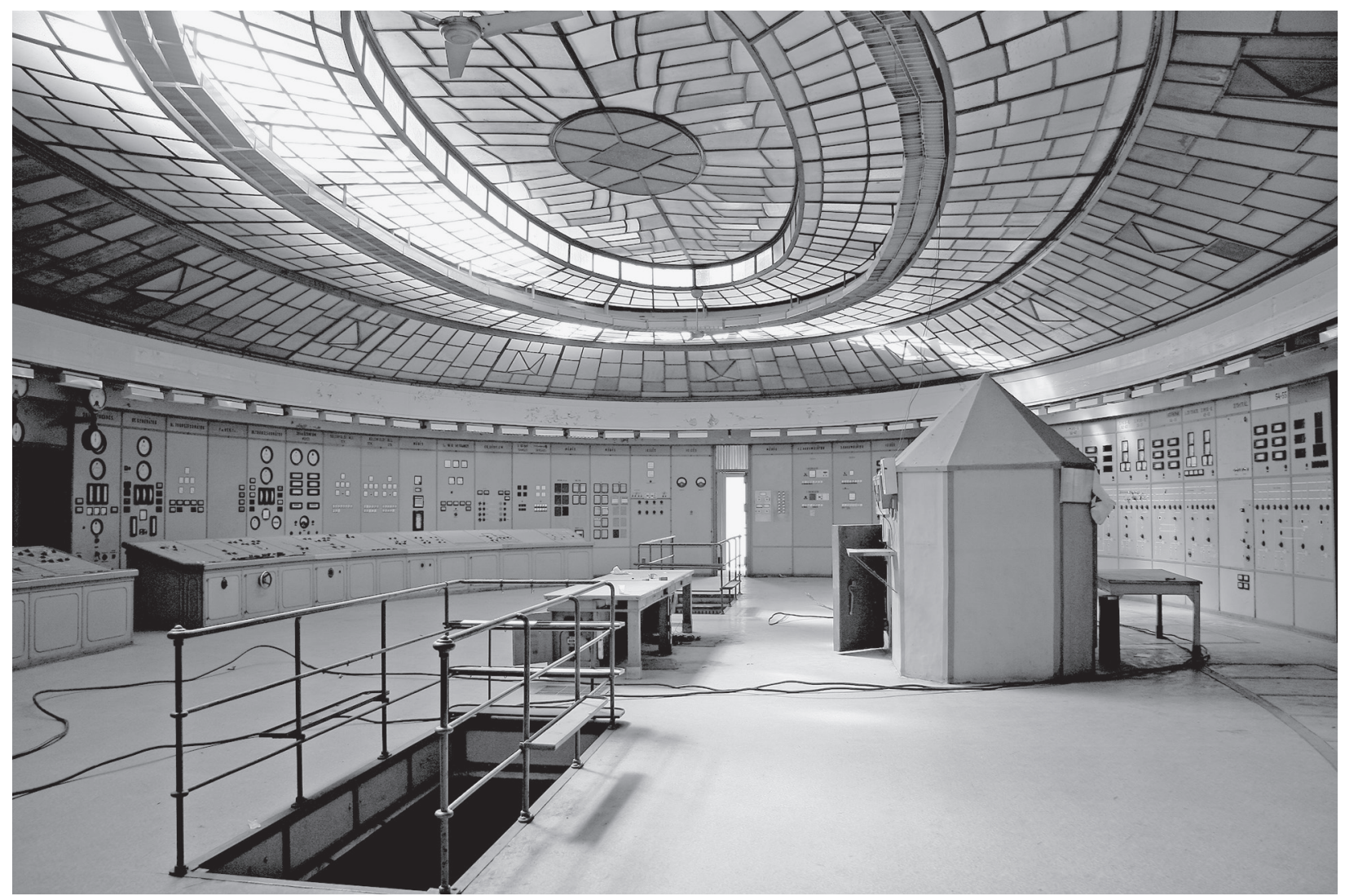

Fig. 18. The control room of Kelenföld Power Station (photo: Galacánu Efstatia, 2008)

drawn over it. As can be seen from the photographs taken of the generator facilities, the pictorial style of the New Objectivity (Neue Sachlichkeit) was perfect for showing industrial architecture that featured the latest technology. One of the reasons for this is the fact that modern architects firmly believed that industrial architecture, while keeping a close eye on functionality, had every right also to be artistic and to exert an overall artistic impression. The transparency of space and the open rooms that revealed different planes at the same time meant that such buildings bore direct comparisons with the landscapes of Cézanne and with Picasso's evocations of space. ${ }^{53}$ As Jenô Padányi Gulyás wrote about the control room of the power station, "A well-designed film scene is made reality before the observer's eyes, and alongside all the cinematographic impact, one can feel that nothing is there without a reason, and that everything has its own, properly considered place [...] Not only the switch room, with its oval glass roof, its soft green rubber flooring and its technical panels with illuminated switches, but the entire interior of simple, white-painted reinforced concrete, encompassing switching booths, choke coils, cable terminals and transformers, generates the aesthetic pleasure of order and purpose. ${ }^{" 54}$ Among the foreign

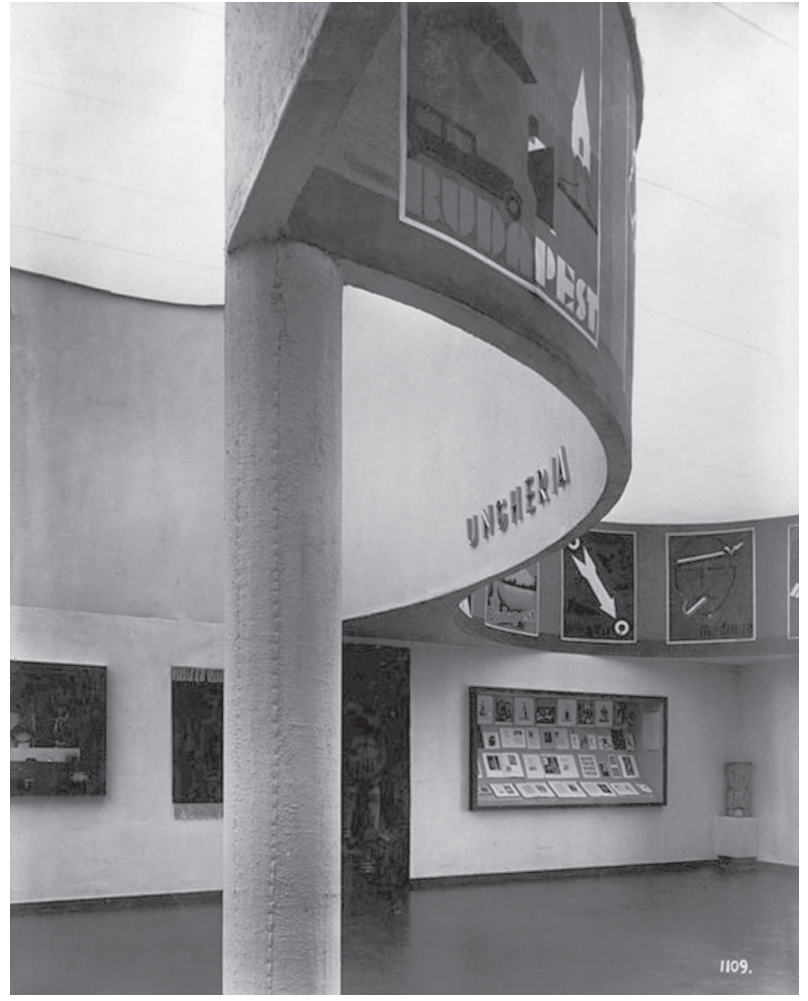

Fig. 19. Fifth Milan Triennale, 1933, the interior of the Exhibition of Hungarian Industrial Artists designed by Virgil Bierbauer and Gyula Kaesz (photo from 1933; IPM 24.551/1) 


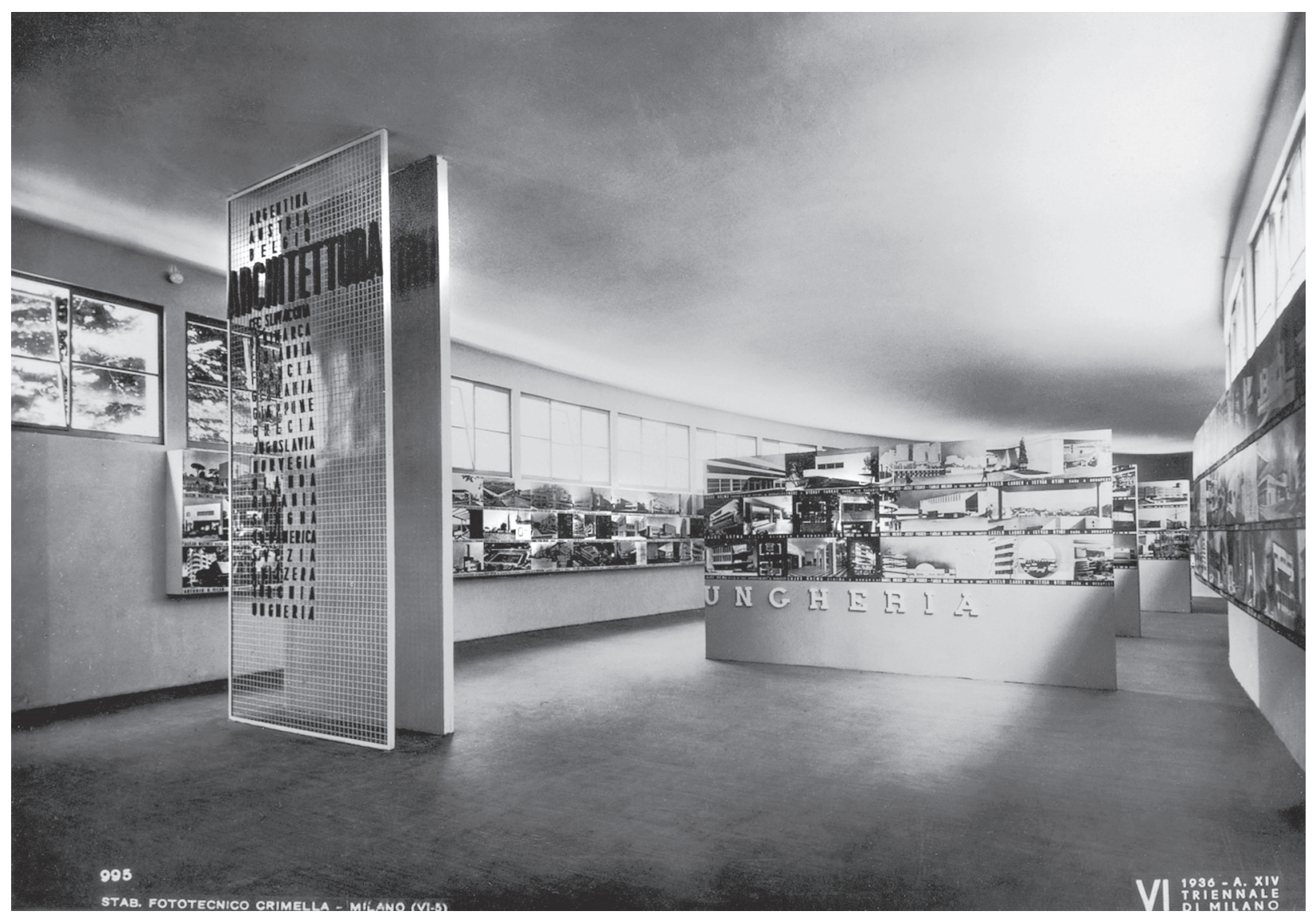

Fig. 20. Sixth Milan Triennale, 1936, Hungarian Architectural Exhibition (photo from 1936; MÉM Borbíró-hagyaték GYN: 659. 22. doboz)

analogies, Bierbauer regarded the power station in Rummelsburg (Germany) as the most direct precedent for his facility in Kelenföld. ${ }^{55}$ The next stage, however, was for Kelenföld to serve - in terms of design solutions - as the precedent for his airport, as can be seen with the help of architectural photographs taken of the two sites. The purpose of these photographs was to enable the internal architectural space and the accompanying modern equipment to be revealed optically in order to facilitate a kind of visual interpretation.

The main visual elements of the switch room in Kelenföld are the control panel, reflecting the most upto-date technology around at the time, and the enormous glass dome, providing natural light (Figs. 17-18); in Budaörs Airport too, the circular central space and its fittings form the main focus (Figs. 1-3, 28, 30, $32-36,90)$. One essential difference is that whereas the control room is open towards the sky, the airport waiting room is also open towards the sides. Perhaps the biggest difference, however, is that the airport terminal was brought alive by the passengers and visitors passing through, while the switch room - in accordance with its function - was private and closed off to visi- tors, and operated by just a few specialist members of staff. In November 1936, the writer Zsigmond Móricz expressed his thoughts on the power station as follows: "The hall, the most beautiful electrical facility in the world, gives a rather cold impression. A long line of cupboards stands in motionless serenity, like waxworks. What remains with me most strongly is the fact that the doors are all under lock and key, and that with so many machines, in a hall that is eighty metres long and forty metres wide, there is not a single person. The machines are functioning, and the staff who control them are themselves outside the locked doors, watching the work happen in front of their switching panels." 56 The power station, both aesthetically and formally, is an outstanding example of pure functionalism imbued with artistic taste; it was universally admired by its contemporaries, and some even accorded it a sort of abstract role. The abstract message appeared both in the unique spectacle of the facility and in the industrial-scale production of electricity and conversion of energy; after all, as metropolises continued to grow, the industrial buildings that provided them with electricity were necessarily large and impressive, in 
accordance with their importance. It is no coincidence that the subject was a source of inspiration for fine artists as well: the enormous mural by Raoul Dufy, titled The Electricity Fairy, was one of the most spectacular artworks on show at the Exposition Universelle in Paris in 1937. Of all the photographs taken of the control room inside the power station, the most impressive are those by Tivadar Kozelka (1885-1980), a specialist in architectural photography (Fig. 17).

\subsection{Exhibition architecture in the career of Virgil Bierbauer (1933-1936)}

Bierbauer took part in several architectural exhibitions in Italy, and he was also invited to collaborate in organising exhibitions on a couple of occasions. ${ }^{57}$ When it came to the art featured at modern exhibitions, ${ }^{58}$ he was particularly interested in the works of Italian designers who used simple devices - newspaper cuttings, photos, easy-to-move grids, ellipses and spirals - and limited materials to achieve outstanding visual effects. Because of the revolutionary solutions on display there, he was particularly enthralled by the exhibition held in Rome in 1932 to commemorate ten years since the beginning of fascist power, which the Italians themselves regarded as a gigantic symphony: "[...] visitors were not received in a capacious hall, but had to pass through tall and narrow corridors, like cliff crevices, to reach the first room, where the walls were covered with newspaper cuttings magnified to human dimensions, photographs blown up to several times lifesize, and immense photomontages [...], "wrote Bierbauer in 1935. ${ }^{59}$ The "Mostra della Rivoluzione Fascista" involved the participation of such artists as Mario Sironi, a major exponent of aeropittura, the architect Giuseppe Terragni, and the Futurist Enrico Prampolini. ${ }^{60}$ The periodical Tér és Forma did not report separately on this exhibition, but the following year (1936) it printed a photograph of a pavilion at the Budapest International Fair - designed by the architect György Kórody - whose tall façade, split into three axes and divided into vertical blocks, was virtually the reincarnation of the exhibition building in Rome. ${ }^{61}$ The aeronautical exhibition in Milan - "Mostra dell'Aeronautica Italiana," 1934 - was also featured in the periodical because of the modern message and approach of the event. ${ }^{62}$ Virgil Bierbauer was first assigned a role as coorganiser of the Hungarian section at the Fifth Triennial in Milan in 1933 (Fig. 19), but he was also a member of the Hungarian architecture team at the Sixth Trien-

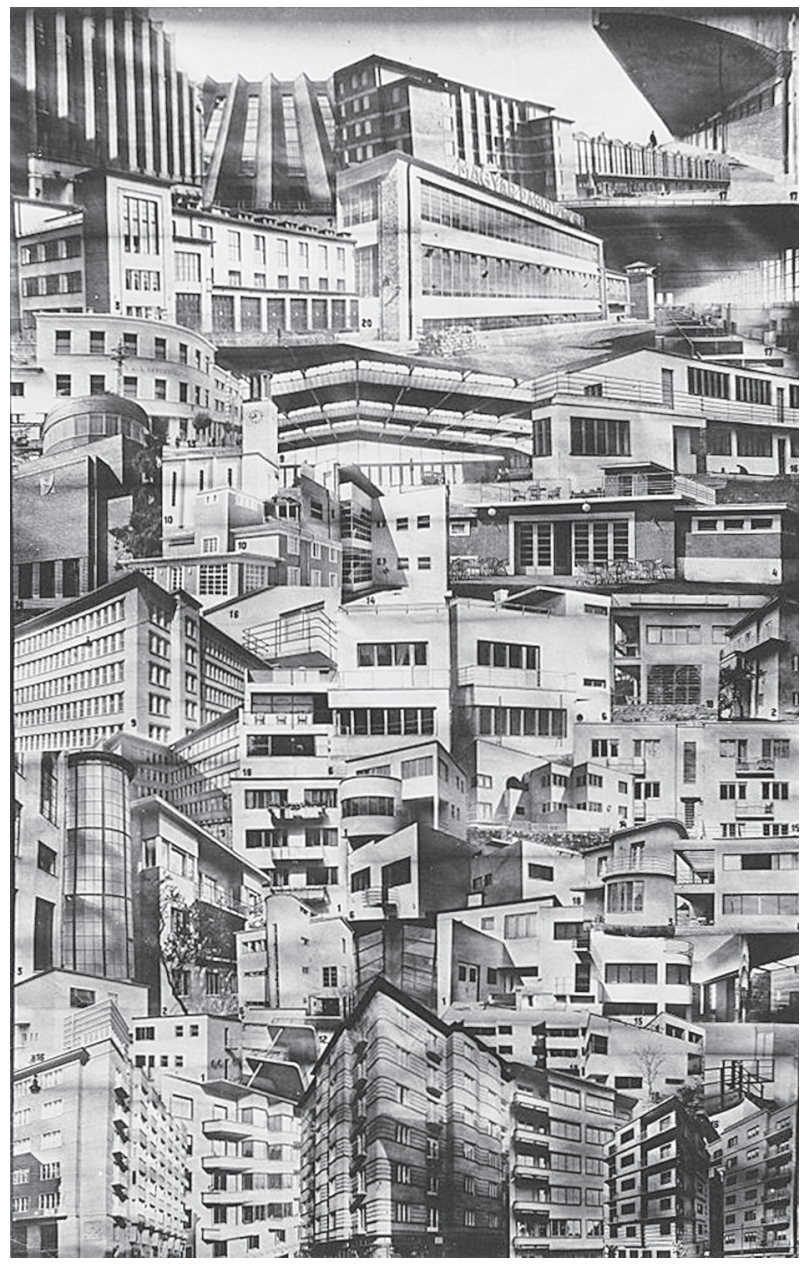

Fig. 21. Fifth Milan Triennale, 1933, a photomontage of the works of Hungarian architects by György Radó,

Ferenc Szántó and Virgil Bierbauer

(published in Tér és Forma 6. 1933. 99; IPM 24.544)

nial (Milan, 1936; Fig. 20). At the triennial exhibitions he had noticed the huge popularity enjoyed by the montage technique - known in Italian as fotomosaico ${ }^{63}$ -, and it may have been due to this that in 1933 he opted to present the achievements of Hungarian architecture in a similar mosaic form ${ }^{64}$ (Fig. 21). In an article he wrote in Tér és Forma looking back on its first five years, he wrote of the montage, "The path that we have forged may best be measured in the photomontage that appears on the front of this issue, which was made for the International Architecture Exhibition in Milan so as to give a visual summary, in compliance with the intentions of the organisers of the exhibition, of the direction and endeavours being pursued by the best in Hungarian architecture." ${ }^{165}$ In 1936, the Hungarian architectural materials at the Triennial were arranged by Agnoldomenico Pica in a modern style, with the customary elegance of Italian exhibition organisers. ${ }^{66}$ 
Inspired by the Italian example, Bierbauer often made use of the tools of combinatory and artistic imaging. An example of this can be seen in the aforementioned pavilion for the Rimamurány-Salgótarján Ironworks at the Budapest International Fair, which was one of his most successful commercial pavilions ${ }^{67}$ (Figs. 13, 22, 52). Fully aware of the fact that the exhibits themselves - tools, iron structures, metal parts and other factory products - would not be easy to present in an interesting way, he compensated in his design of the pavilion interior. The raw metal objects were not shown in installations, but displayed as they were, almost at random, while the spectacle was complemented by a montage composition that ran around the walls, which Bierbauer commissioned Mrs Elemér Marsovszky to design. By giving the composition an undulating arrangement, the exhibition space benefited from an additional sense of dynamism. The montage installation, mounted on large panels, showed scenes related to the products and activities of the ironworks.
3.4. Tér és Forma ("Space and Form"), the magazine of modern architecture, 1928-1948

Between the wars, illustrated magazines and the pictorial supplements distributed with daily newspapers played a major role in communicating the modern ideals of life and all the objects that went with it, and it was not long before this led to a significant increase in the demand for modern photography in the press dealing with architecture and its related fields. This was the golden age of such European and American press classics as Life, Vogue, and Magnum, and in Hungary these, together with locally produced periodicals, inundated readers with information about the latest technological innovations in American cities and the social and lifestyle mobility that came with the transport revolution. ${ }^{68}$ The first Hungarian architectural publication to deal with the new approach to living was a special supplement of Vállalkozók Lapja [literally: "The Entrepreneurs' Paper"], which bore the separate subtitle of "Tér és Forma" ("Space and Form"). ${ }^{69}$

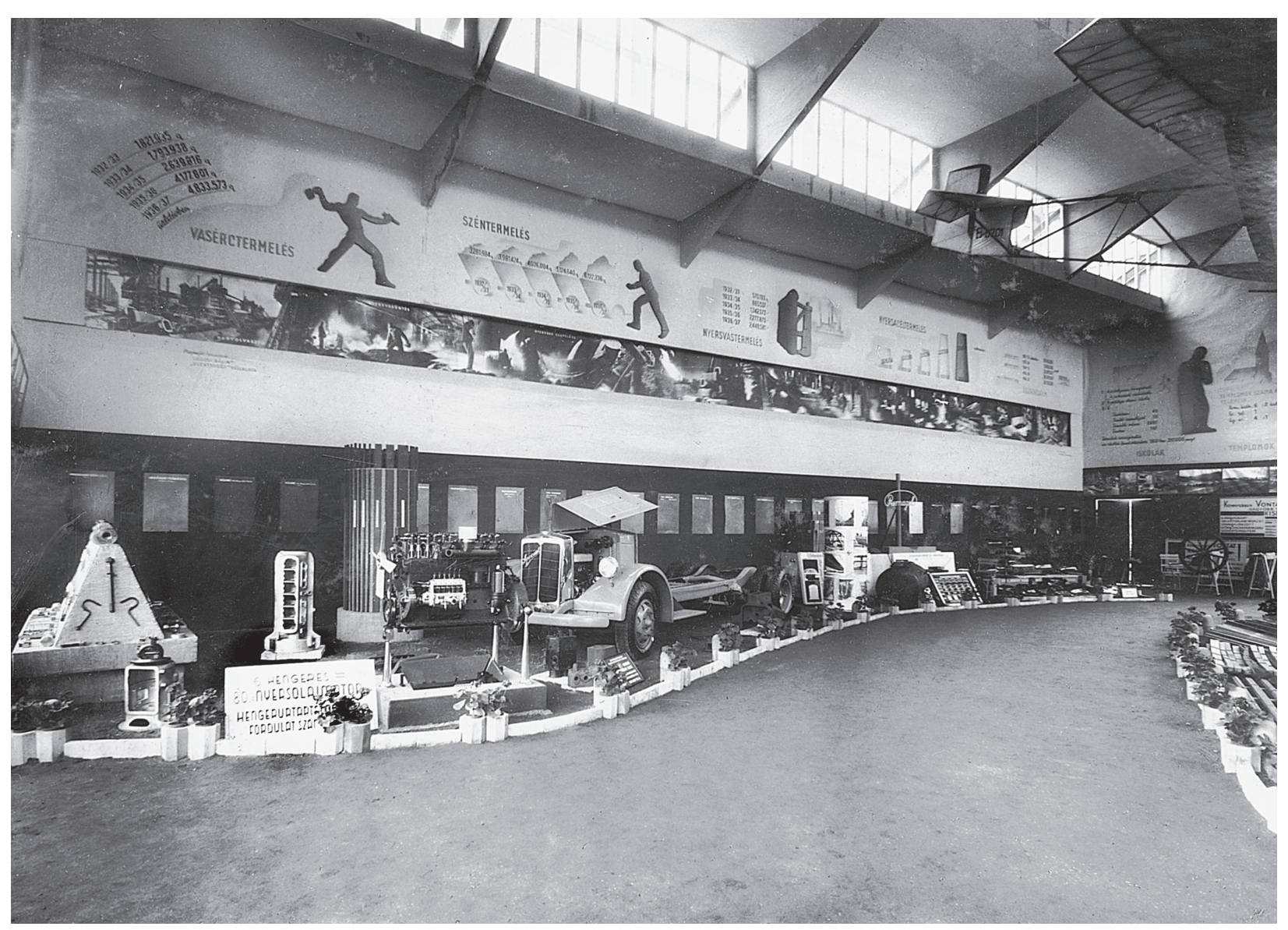

Fig. 22. Interior of the Pavilion of the Rimamurány-Salgótarján Ironworks at the Budapest International Fair, architect: Virgil Bierbauer, 1939; the montage decoration on the wall by Mrs Elemér Marsovszky (photo: MÉM Borbíró-hagyaték GYN: 659. 22. doboz) 
The publication filled a gap, because only a narrow cross-section of the latest achievements in architecture was known in Hungary, mostly through foreign periodicals. The philosophy of the periodical, which was published monthly in an art nouveau (Hungarian Secession) style, was at first not bound to any particular style of architecture, and this approach is reflected in the pictures it chose to include. Its first report on modern architecture was in the January 1927 issue, and it was accompanied by a few high-quality photographs, licensed from abroad, of the Werkbund exhibition in Stuttgart. By the end of 1927 it was clear that the architectural content had outgrown its original frames, and the publishers decided to relaunch the magazine as an independent specialist periodical, starting in 1928. Tér és Forma now placed its editorial focus on functionalist architecture, and the periodical was illustrated with quality photographs (Figs. 14, 23). The owners entrusted Bierbauer to lead the new periodical, and his editorship, which lasted until 1942, marked a defining period in the architect's career. ${ }^{70}$ One of the publishers' initial and long-lasting strategic elements

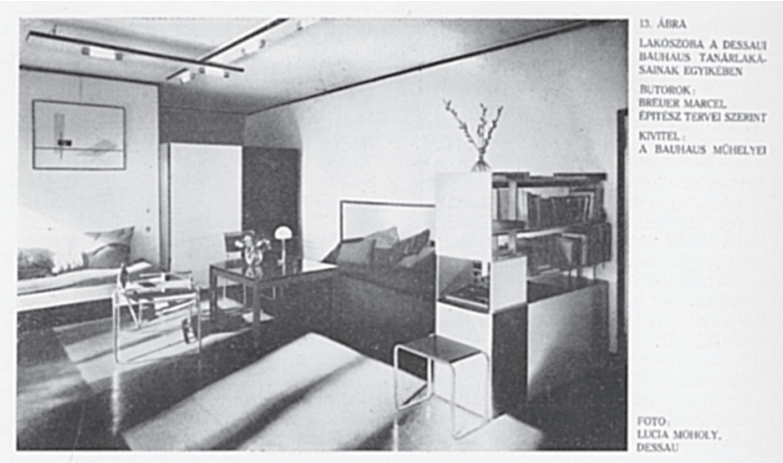

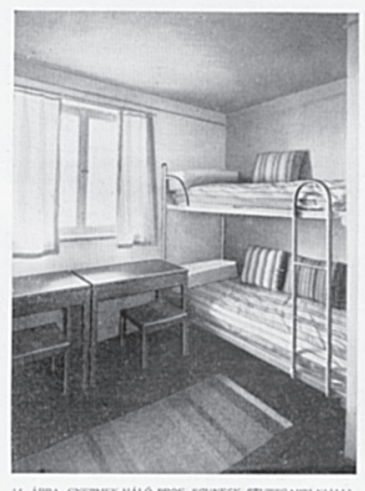

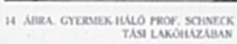

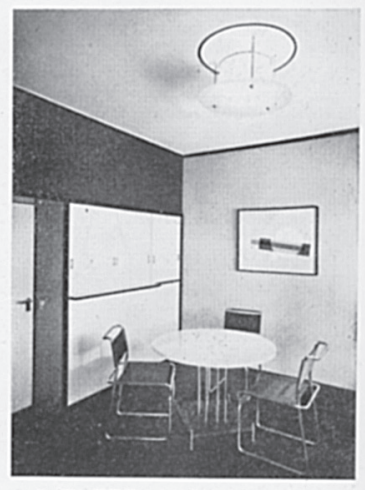

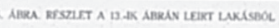

Fig. 23. An illustrated page in the first issue of Tér és Forma: Modern Interiors in Dessau and Stuttgart, with photos by Lucia Moholy (Tér és Forma 1. 1928. 41) was to promote the contemporary architectural group CIRPAC, who represented the progressive movements in the field. Thematic issues dealing specifically with works by members of the group were published in 1932 and 1934. In the first year, editions of the periodical also covered contemporary rational home architecture, mostly in reporting on solutions that had been devised to solve the lack of housing that has persisted since the end of the First World War. The architect Farkas Molnár (1897-1945) wrote, in one of his early articles, "Even in the smallest homes, by which we mean those being made for labourers, peasants and less wealthy people, there should be more than one room, [...]. It is essential to have a bathroom that lets in the sunlight, and separate bedrooms for the adults, for the boys and for the girls in the family, and it is also essential to have a terrace or roof garden for exercise and rest. The concept of a home with one room and a kitchen should be wiped forever from our vocabulary and replaced with a dwarf apartment that contains all of these rooms. Modern architects have promised to produce this hygienic type of dwarf apartment at a realistic price. ${ }^{" 11}$ Molnár's ideas were not borne out in the end, because the programme of modern architecture increasingly turned towards serving the needs of the upper middle class and the bourgeoisie. The periodical also published writings by, among others, the critic Ernô Kállai (1890-1954), the art writer Pál

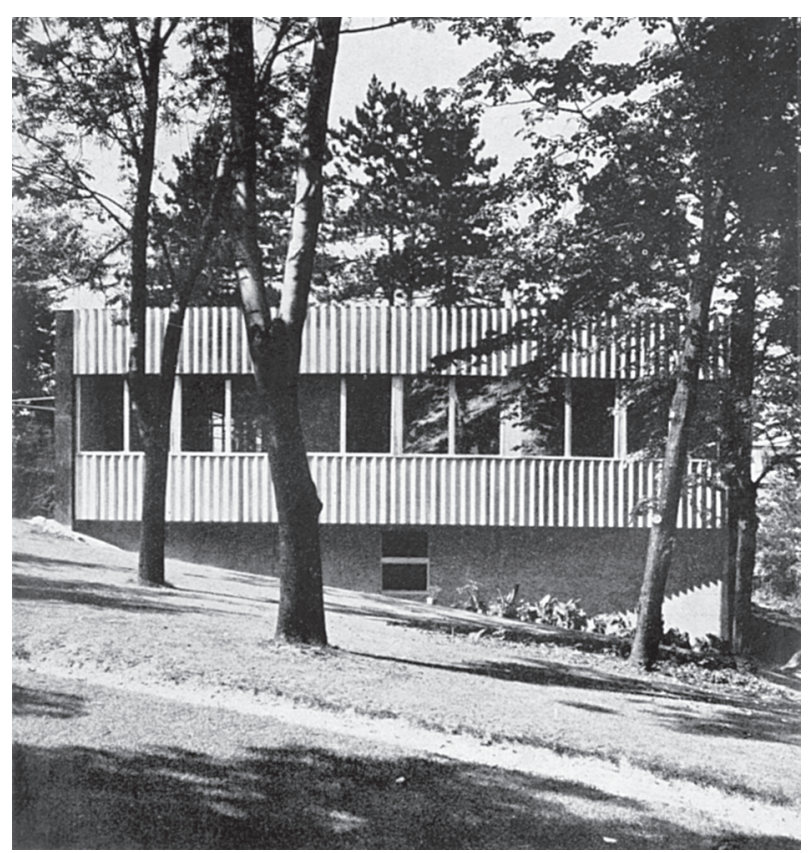

Fig. 24. Family house covered with eternit corrugated board in Budapest, architect: Farkas Molnár (photo: Mrs Elemér Marsovszky; published in Tér és Forma 10. 1937. 372) 
Nádai (1885-1945), the future dramatist Gyula Háy (1900-1975), the architect Lajos Kozma (1884-1948) and the painter Sándor Bortnyik (1893-1976). Among those who read the periodical was Walter Gropius, whose housing estate in Dessau was reported on by Molnár in 1928. The edition of Tér és Forma that featured the highest number of photographs, a hundred in total, was published in 1930 as a summary of Hungarian modern architectural achievements to coincide with the 12th International Architecture Congress, held in Budapest. The majority of the photographs were taken from previous issues. Thanks to the evergrowing international connections enjoyed by the editorship after 1928, the periodical became substantially richer in terms of its photographic material. A unified style and concept of photography was reflected in its pages, and this increasingly put the periodical on a par with its foreign counterparts.

Photos of Hungarian architecture were commissioned by the periodical from Tivadar Kozelka, Ernô

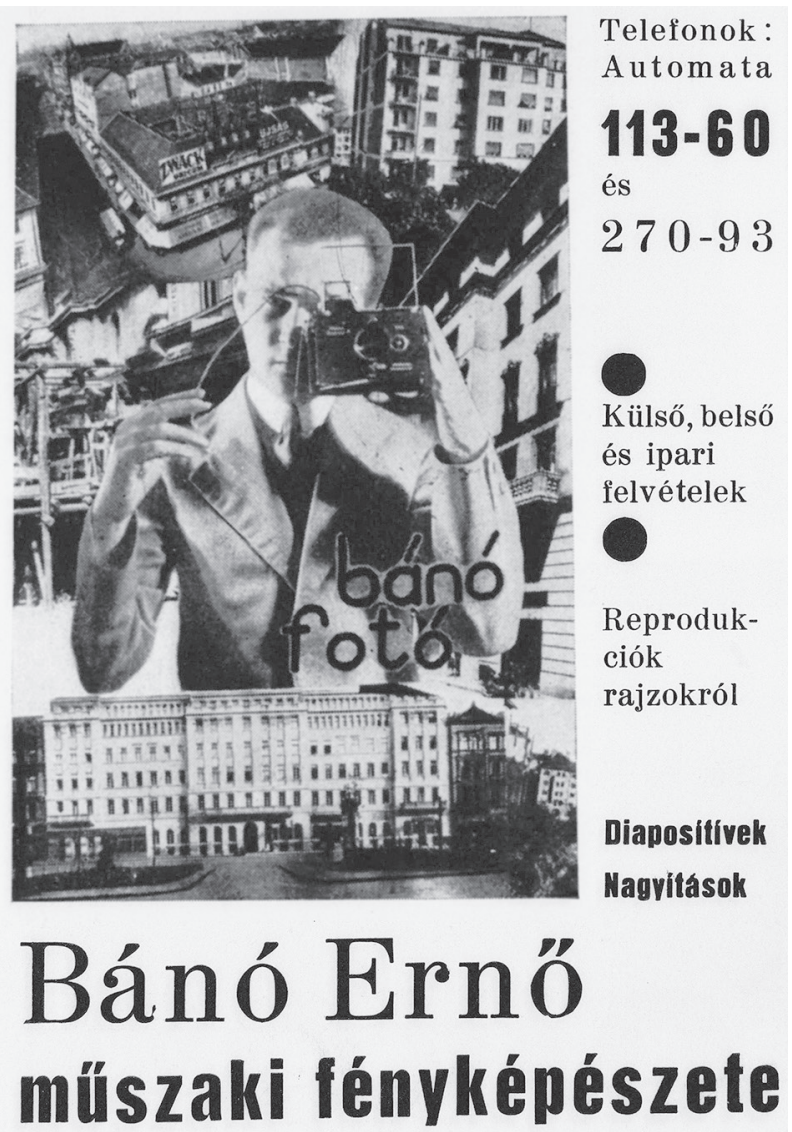

Budapest VI, Podmaniczky ucca 10 (Vilmos császár út mellett)

Fig. 25. Advertisement of architectural photographer Ernô Bánó (published in Tér és Forma 3. 1930. III.)
Bánó (1888-1941?), Zoltán Seidner (1896-1960)72, Olga Máté (1879-1965), József Pécsi (1889-1956), Ferenc Haár (1908-1997), Károly Escher (18901966), and, already mentioned on several occasions, Mrs Marsovszky (Fig. 24). Several of the photographers were autonomous artists in their own right (Fig. 25), who produced great works both in the field of architectural photography and in other areas of the arts. ${ }^{73}$ Bierbauer proposed an interesting role for photography by claiming that its ability to show buildings in such an effective manner was one of the reasons behind the emergence of formalism. The quote about this reads, "... our architects only saw these selected photographs and never went around the buildings, never checked if the interesting forms were correctly or falsely related to the purpose of the buildings, that is, if these forms were true and justified, or lies and formalities. The impressions remained, however, and diverted architects towards a certain path of form creation, which they considered modern - and when their tasks brought these designers to the drawing board, whether they knew it or not, subconsciously, or perhaps even consciously, they began to work under these influences. [...] Of course, sometimes it turned out that their solutions to spatial tasks were perfectly suitable [...] It was amid such circumstances and under such influences that an aesthetic codex of architecture developed that was deemed to be modern - and this could be deduced from a number of [Hungary's] newest buildings." ${ }^{74}$ It is not clear exactly which period of photographs the author of the text is referring to, nor is this helped by the context, which is equally critical of the faults of "modernesque" (only modern on

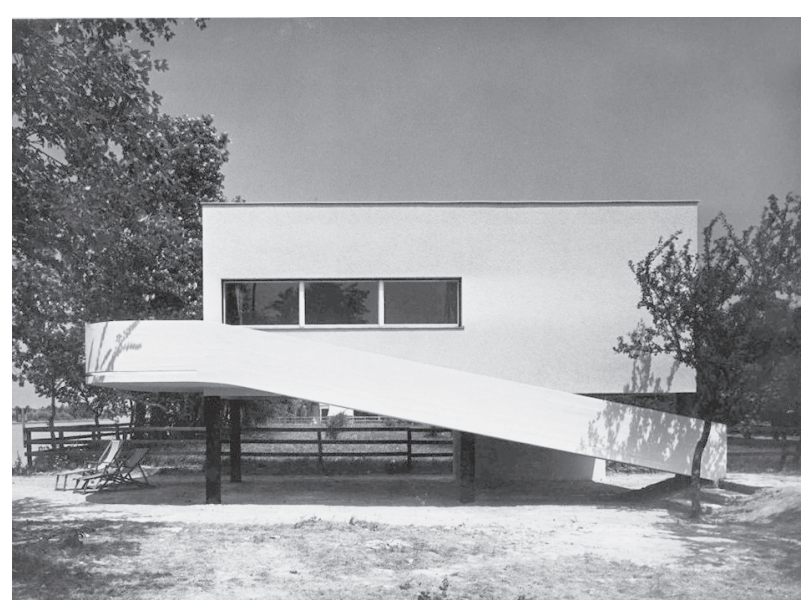

Fig. 26. Weekend house on the Danube, architects: György Farkas and Endre Farkas (photo: Zoltán Seidner; IPM 22.534/1-3; published in Tér és Forma 8. 1935. 361: "a holiday home in the Lupa island") 
the outside) apartment buildings erected before 1945 and of socialist buildings. Tér és Forma played a pioneering role in generating publicity for modern architecture, although in its early days it was a challenge to fill its pages with photographs of modern buildings. Eventually more and more people shifted from the moderately and progressively thinking camps to the group of modern architects, and throughout the 1930s there was not only an increase in the amount of photographs, but also an increasingly unified style of architectural photography, which gave the periodical a certain standing alongside foreign publications (Figs. 26-27). To maintain this position, Bierbauer published a large number of foreign architectural photos. In 1930 he wrote, "our aim is to provide a fresh and varied selection of the best foreign photographs, so that our architects can, where possible, survive without the foreign publications, which are far more expensive than Tér és Forma. It seems that this aim has largely been achieved, because in some cases we have reported on certain major foreign projects even before they appeared in famous magazines with decades of history behind them." 75 Some of the exceptionally high-quality photographs doing the rounds in the press became as symbolic as the buildings themselves. One example of this is the summer house on Lupa Island, designed by Lajos Kozma, which was made famous around the world by the iconic photo taken by Zoltán Seidner; the photographs of Budaörs Airport taken by Mrs Marsovszky are further examples, for they appeared all over the international press soon after the airport was opened. Financial difficulties began to emerge towards the end of the decade, and the size of the periodical was reduced from 28 pages in 1939 to just 16 pages in 1942. When József Fischer took over from Bierbauer as editor, he succeeded in reviving the periodical for a short while, but in 1948 only two editions were published, although they did feature a new cover and inscriptions in four languages. It was not this that brought the periodical to an end, however, but the seizure of power by the communists in 1948 .

Among Bierbauer's foreign colleagues, it is important to mention Alberto Sartoris, an Italian architect resident in Switzerland, who built up a similar network of professional contacts and over a period of twenty years built up a collection of over 6000 photographs on the theme of architecture. The volumes he edited became legends of their own time: the volumes of Gli elementi dell'architettura funzionale: Sintesi panoramica dell'architettura moderna, published in 1932, 1935 and 1941, contained 1135 illustrations; the three volumes

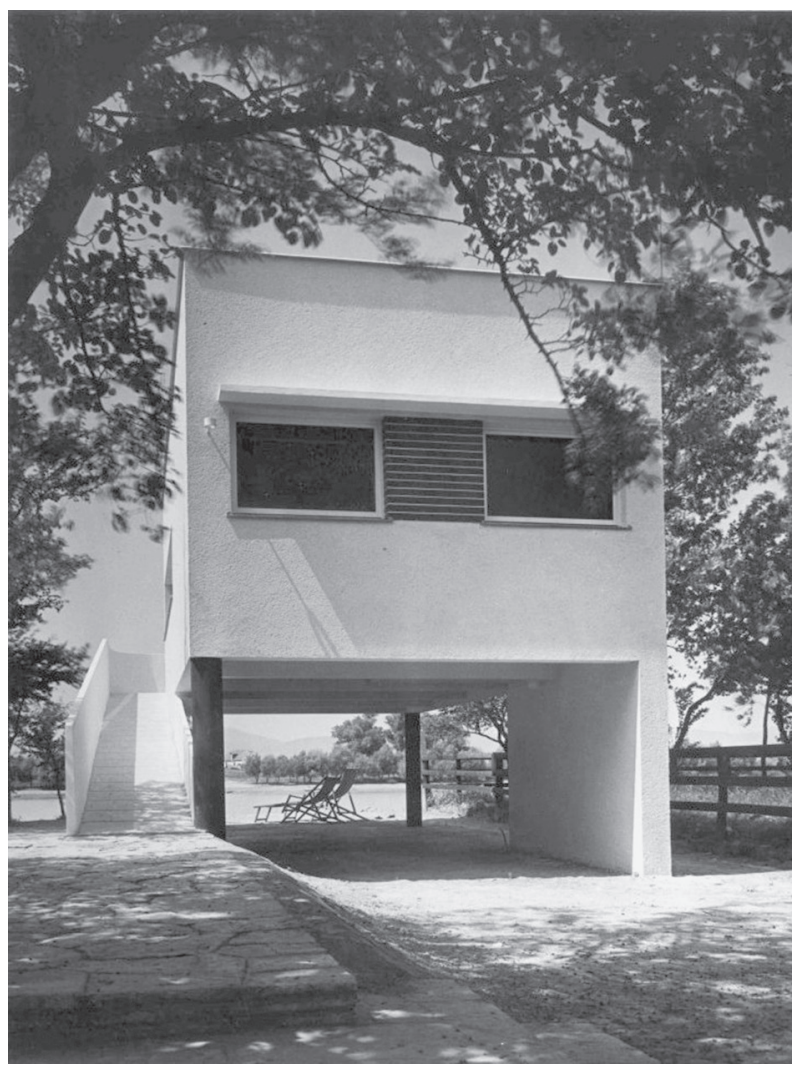

Fig. 27. Weekend house on the Danube, architects: György Farkas and Endre Farkas (photo: Zoltán Seidner; IPM 22.534/1-3; published in Tér és Forma 8. 1935. 361: "a holiday home in the Lupa island")

of L'Encyclopédie de l'architecture nouvelle included 2230 pictures, most of them photographs. These publications still embody the corpus of the modern movement, as emphasised by Antoine Baudin in his 2005 publication on the Sartoris archive. ${ }^{76}$ The vast majority of the 207 pictures in the volume that have something to do with Hungary are mostly of residential buildings, although the collection also contains a few pictures of Budaörs Airport (1937) as well as the Palatinus Baths on Margaret Island in Budapest, designed by István Janáky (1937). In some cases the authors of the photographs can be recognised from their signatures or marks (such as "Zoltán Seidner," "Magyar Film Iroda" [Hungarian Film Office], "Ernô Bánó," "Marsovszky" and "Escher"), while other photos are unmarked. The photographs of Budaörs Airport were published in volume III of Elementi (along with a small house by József Molnár (1902-1983) and a villa by János Wanner) and again in the first edition of the Encyclopédie (1948), which also featured works by Pál Ligeti (1885-1941) and József Molnár. In the latter work, Sartoris had the express intention of demonstrating how Le Corbusier had influenced Hungarian architecture..$^{77}$ Based on the 
Hungarian photographic material in the collection, Baudin concluded that Hungarian architectural photography did not make direct use of the perspectives employed by new experimental photography and by so-called "new architecture." ${ }^{\text {" }} 8$ Having reviewed the selected photographs for other countries, I am of the opinion that - while Hungary was admittedly not at the forefront in this regard - the view taken by Antoine Baudin is somewhat exaggerated, and there is therefore a need to modify this view in the literature on the history of photography, to the credit of Hungarian architectural photographers.

\section{DESIGNS AND THE COMPLETED BUILDING}

\subsection{Virgil Bierbauer's competition design}

"After so many failures of foreign origin, it was equally hard to create something original as to produce an airport that was in every respect Hungarian, for this was the first time we had faced this task here at home." (Elischer 1937)

Virgil Bierbauer and László Králik submitted separate designs for the airport competition. Králik's design has not survived, so we know nothing about its details, only that his concept for the terminal was based on a long, narrow floor plan, perhaps interrupted with an angle at some point along its length. Bierbauer's design, by contrast, had a fundamentally central arrangement, focused around a circular building. He summarised his concept as follows: "...I have formulated a solution based on depth, with corridors branching off the circular hall to the right and to the left, leading slowly down to the basement, with the inspection and luggage transportation facilities between them. These are bridged by the entrance leading to the mezzanine restaurant. The basement corridors would have led into the embarkation buildings placed along the concrete runways, where hydraulic elevators would have carried passengers up to the planes, or from the planes to the corridors. I located the services in the south wing, while the north contained accommodation for passengers and pilots, and at the very top, above the mezzanine restaurant, would have been the command and control rooms." The competition design - as can be discerned from the technical description - came up with a solution for smoothly carrying out the processes of movement in the passenger terminal building, as specified in the design programme: "The necessary sequencing of tasks related to departing and arriving passengers requires the premises serving these purposes to be arranged along an axis that is perpendicular to the path of vehicular traffic, as the main direction of flying." 79 The two architects received a commission from the evaluating committee to combine their winning designs and to draw up the planning permission and construction plans. Creating a whole out of the two opposing concepts would have been so complex, however, that Králik finally accepted Bierbauer's design, with only some necessary changes being implemented. As Bierbauer's wife noted in her diary, "The year 1936 was important for us because of the decision on the contest for Budaörs Airport, because the task of constructing it and working out the final plans was given jointly to V's [Virgil's] design and to that of László Králik. There is no question of the two diametrically opposed plans being brought together. But Králik was so preoccupied with his slaughterhouse projects, in which he is something of a specialist, that he completely agreed with a slightly rethought and simplified version of V's plan. [...] The call for designs stipulated the exact surface area and volume, plenty of offices, and the separation of passenger traffic from customs and departures from arrivals. In V's plan all this was solved creatively by playing with the levels in three dimensions." ${ }^{80}$ Four pages of the competition design are known, containing two floor plans, four cross-sectional drawings, and a freehand projection drawing of the front elevation, only the latter of which was not published at the time ${ }^{81}$ (Figs. 28-30). There is no known runway-facing elevation of the terminal building, nor an upstairs floor plan. The site drawings that survive from 1935 and 1936 offer an overview of where the airport buildings were to be located. ${ }^{82}$

\subsection{The competition design concept}

The design basically consisted of a bow-shaped main building connected to a circular terminal building located on the central axis above the entrance (Fig. 28). The main building and the terminal building were connected with corridors for departing and arriving passengers. The passenger-related tasks - customs, checks, passport control, offices of foreign airlines were carried out along the corridors, which were also connected to tunnels leading beneath the runway to 
hydraulic elevators. ${ }^{83}$ The other main route for passenger traffic was between the entrance and the restaurant. Passengers would have reached the restaurant, overlooking the runway, along a broad central corridor connecting the round building to the long wing; the semi-circular restaurant terrace can be regarded as the visual counterpoint to the circular building. The highcapacity restaurant and terrace, with its orientation towards the runway, followed the pattern of airports in Western Europe, where passengers, the people accompanying them, and casual visitors alike were entertained with the food and drink and with the spectacle of airplanes taking off and landing. In Bierbauer's competition design, the restaurant functioned as a communal area designed to accommodate a large number of people. The sequence of premises in the wings of the building proceeded along a single range on the runway side, connected to a side corridor running lengthways along the other side; the premises at the ends served auxiliary technical functions. Bierbauer paid attention to planes taking off and landing, to reducing the shadows cast by the wings of the building, and to ensuring that the view of the pilots was undisturbed by making the upright elements of the main building bend inwards away from the runway. To ensure safety, this solution was maintained in the final plan.

The projection drawing shows the concave façade of the main building and the round building projecting from the central axis, with its prominent main entrance and its elegant approach stairway (Fig. 30). The two-storey range of the central curved section of the main building, however, stands out slightly, while the side wings are shorter upstairs, ending with terraces. The front elevation is nevertheless dominated by the emphatically circular, cascade-fronted central building, whose key role is clear from the floor plan. In addition to their simple, unbroken, modern arrangement, the façades are also distinguished by the symmetrically proportioned windows. Due to the lack of plans there is no way of knowing if the upstairs levels of the runway-facing façade would have had balconies or not, but it is likely that terraces were only placed before the restaurant and above the ranges of rooms along the side wings. ${ }^{84}$ On the planning permission drawings, the round building and the modern façade of the main building have been simplified in many respects, and the open terraces on the roofs of the side wings have been moved to the galleries along the upstairs levels.

The competition design was also innovative in its use of materials: metal structures and glass surfaces. Bierbauer planned the underground sections to have a concrete structure and for the upright elements to have steel frames; in order for the entire groundfloor wall section to be covered with glass, he conceived that the runway-facing façade of the so-called "command cross-wing" would consist of consoles. Another important component of the modern design was the lighting, which was especially problematic in the subways. Here too his solution was to use glass, namely skylights measuring 1.2 metres in diameter, covered with cast glass panels, with watertight artificial lighting concealed in their lower sections. The competition design includes many similar solutions which were later used by Bierbauer in an unaltered or evolved form. The overall shape and configuration of the round building was also kept unchanged. The central organisational role of this building was further underlined by its central positioning. Bierbauer also kept some other, less fundamental characteristics of the building, including the metal-and-glass structure of the control tower, as indicated on the cross-section, and the internal spiral stairway leading up to it. ${ }^{85}$

One of the main differences between the original concept and the planning permission design is that the control tower was later relocated above the main building. They are connected by a wide corridor, and only become conjoined in the later design. The way in which the main building is divided up internally is also revealing. In the original design, Bierbauer had placed the command and technical staff in one wing and the pilots separately in the other; in the final version, the command headquarters were located alongside the control tower on the top floor of the central round building (which was now consequently taller), with the pilots and the staff housed in the side wings. The competition design therefore set a new standard for modern airport organisation by completely separating arriving and departing passenger traffic, service personnel and officials. The changes that were requested later, however, such as scrapping the tunnels, upset the original organisational order, forcing Bierbauer to rethink his ideas. As he had to abandon the tunnels, the side wings attached to the bow-shaped building no longer had a function (and were later removed from the design); instead, a new storey had to be incorporated, and the central circular building had to be redesigned to serve several new functions.

These forced changes resulted in a simpler, more elegant building than the one in the competition design, with more purified forms. The bow-shaped main building was transformed into self-standing side wings, while the central circular building also benefited from 
an increase in its physical prominence to match its extra functions. A number of inferences can be drawn from the internal spatial concept of the competition design, compared with the features used in the later, modified design. The reception area changed little, with the seg- ment on the left of the cylinder still housing the offices and (external) desks of the airlines, and the opposite side almost completely taken up by postal premises. The circular arrangement marked a complete break from the convention of long passenger halls placed per-

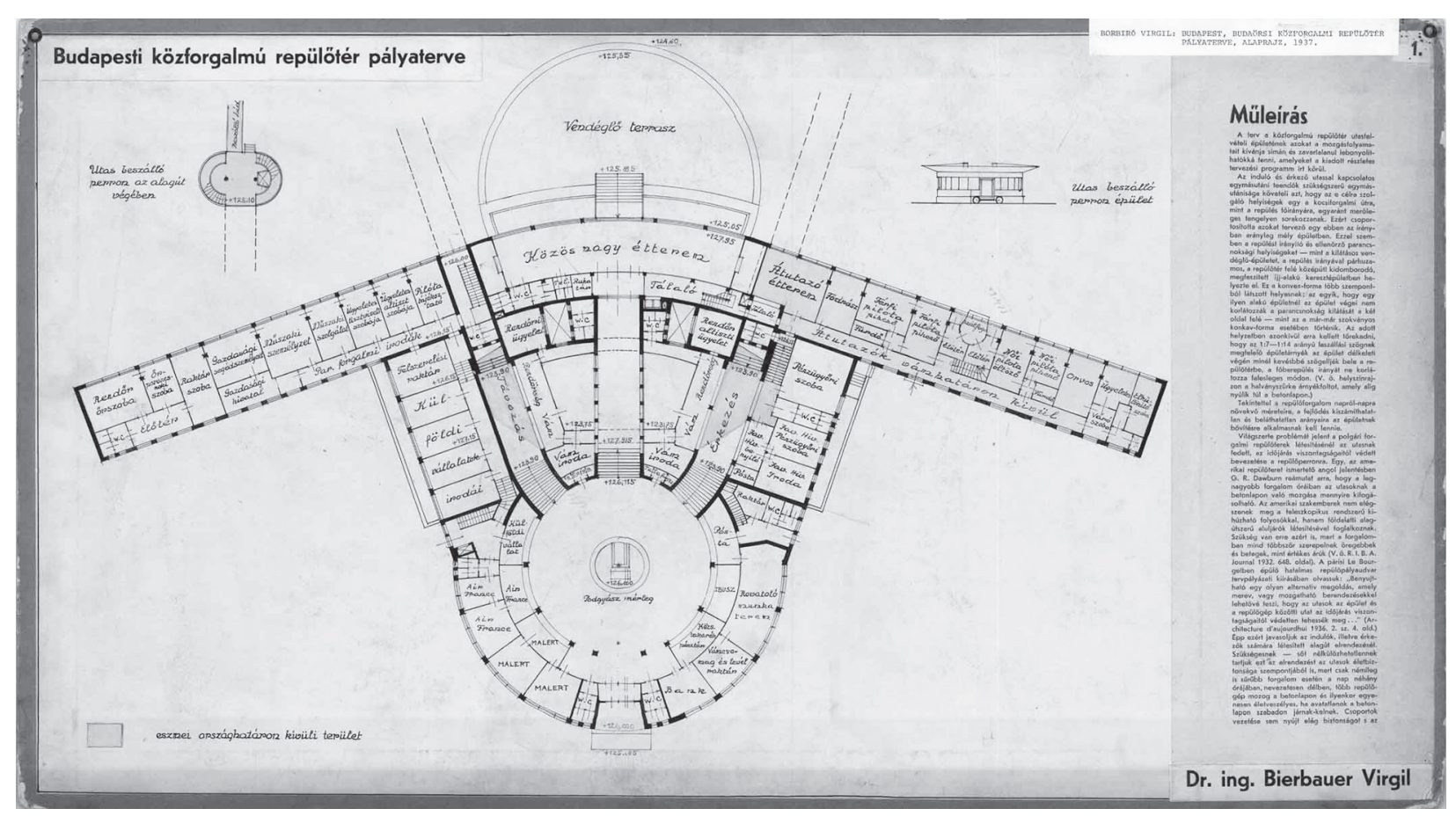

Fig. 28. Virgil Bierbauer: Competition entry for Budaörs Public Airport, Budapest, groundplan, 1937; cardboard, $40 \times 71 \mathrm{~cm}$ (MÉM 69.013.3.2)

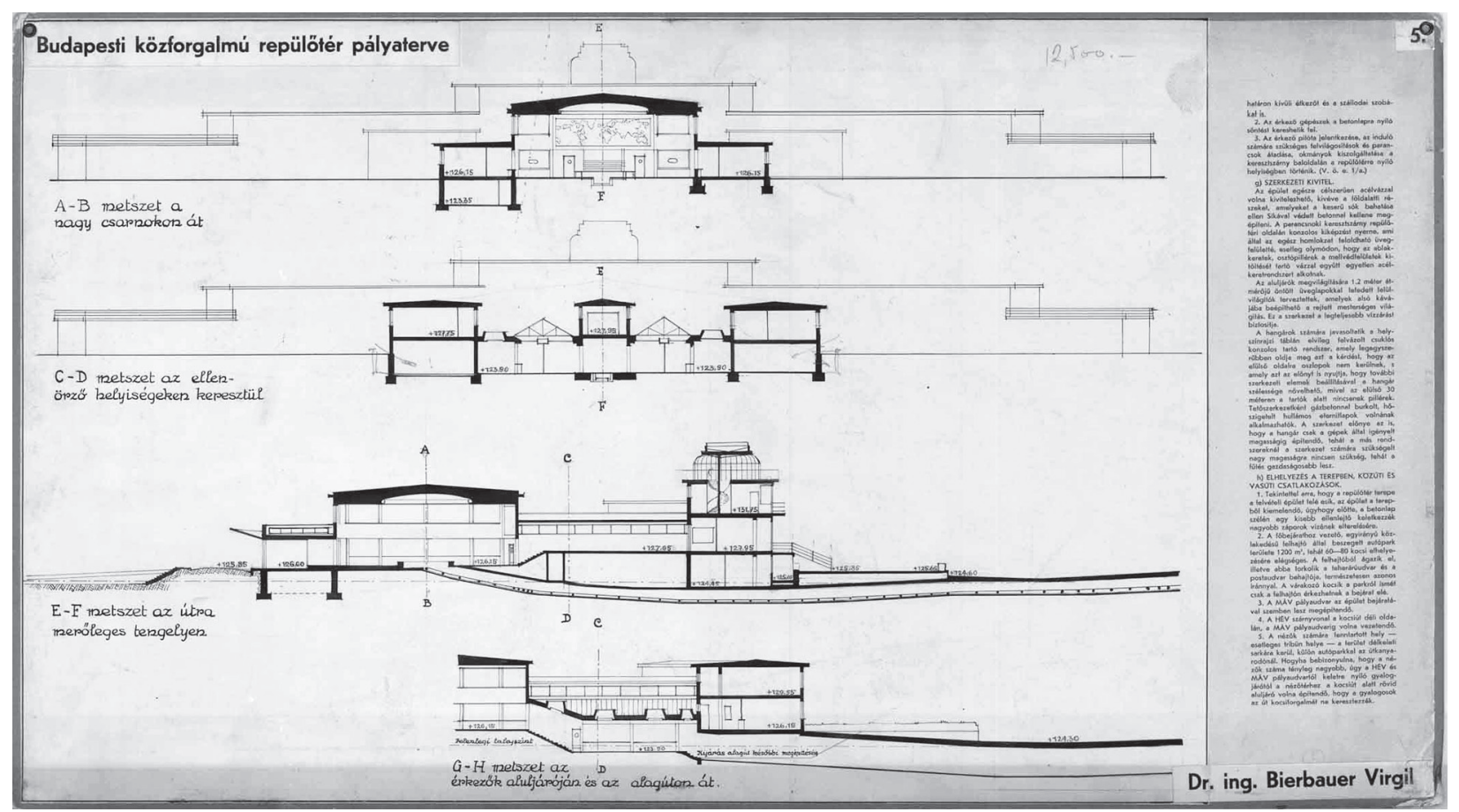

Fig. 29. Virgil Bierbauer: Competition entry for Budaörs Public Airport, Budapest, four cross-sectional drawings, 1937; cardboard, $40 \times 71 \mathrm{~cm}$ (MÉM 69.013.3.1.) 
pendicularly to the direction of traffic, a hangover from the railway termini of the nineteenth century. The most significant changes were in the reorganised functions of the main building: the pilots' accommodation was moved to the opposite side, and the service areas were shifted from the left to the upstairs level of the terminal building. The most substantial alteration concerned the restaurant, which was significantly reduced in size and relocated to a less focal location.

The reception area was not connected in any direct visual way to the runway, and served as a hub where people would simply arrive and move on, making it a variant of the first solutions in the West. (The three stairways leading to the circular vestibule concentrated all the passenger traffic in this area, so the possible problem of congestion remained unsolved.) The terrace and glass windows of the restaurant formed the visual link with the runway. We believe that the question of how to decorate the inside cylinder had not yet arisen, and would only become a concern after Bierbauer had reinterpreted the role and function of the reception vestibule.

\subsection{The planning permission (construction) drawings}

The first report on the finished Budaörs Airport (Fig. 36) and its main hangar (Fig. 31) was published in a special issue of Tér és Forma in 1937. The following year the construction plans for the airport were printed in the official bulletin of the Hungarian Union of Engineers and Architects (A Magyar Mérnök-és Épitész-Egylet Közlönye). ${ }^{86}$ The drawings for the technical documentation were hitherto mostly known from the photographs in these publications, but before the present research was concluded, a photocopy of the original architectural documentation turned up, together with several other plans, in the Military History Archives in Budapest (Figs. 32-34). The documentation not only contained the already published drawings, but also some previously unknown ones, including floor plans for each storey, elevations of the front and rear (roadand runway-facing) façades of the building, detailed drawings of the ground floor and upstairs of the side wing, showing the service areas of the restaurant and hotel, a site plan of the airport and its planned buildings, and cross-sections marked A-B and C-D. The title on the documentation reads: Construction of the Civil Airport in Budapest. The drawings are signed jointly by "Dr Virgil Bierbauer and László Králik, certified architects," and the dates (July and September 1936) are marked on the bottom line on the left of the sheets. The drawings were made to a scale of 1:100, and feature dimensions and the names of the premises. ${ }^{87}$

The plans have some interesting supplements in the Budapest City Archives, consisting of site plans,

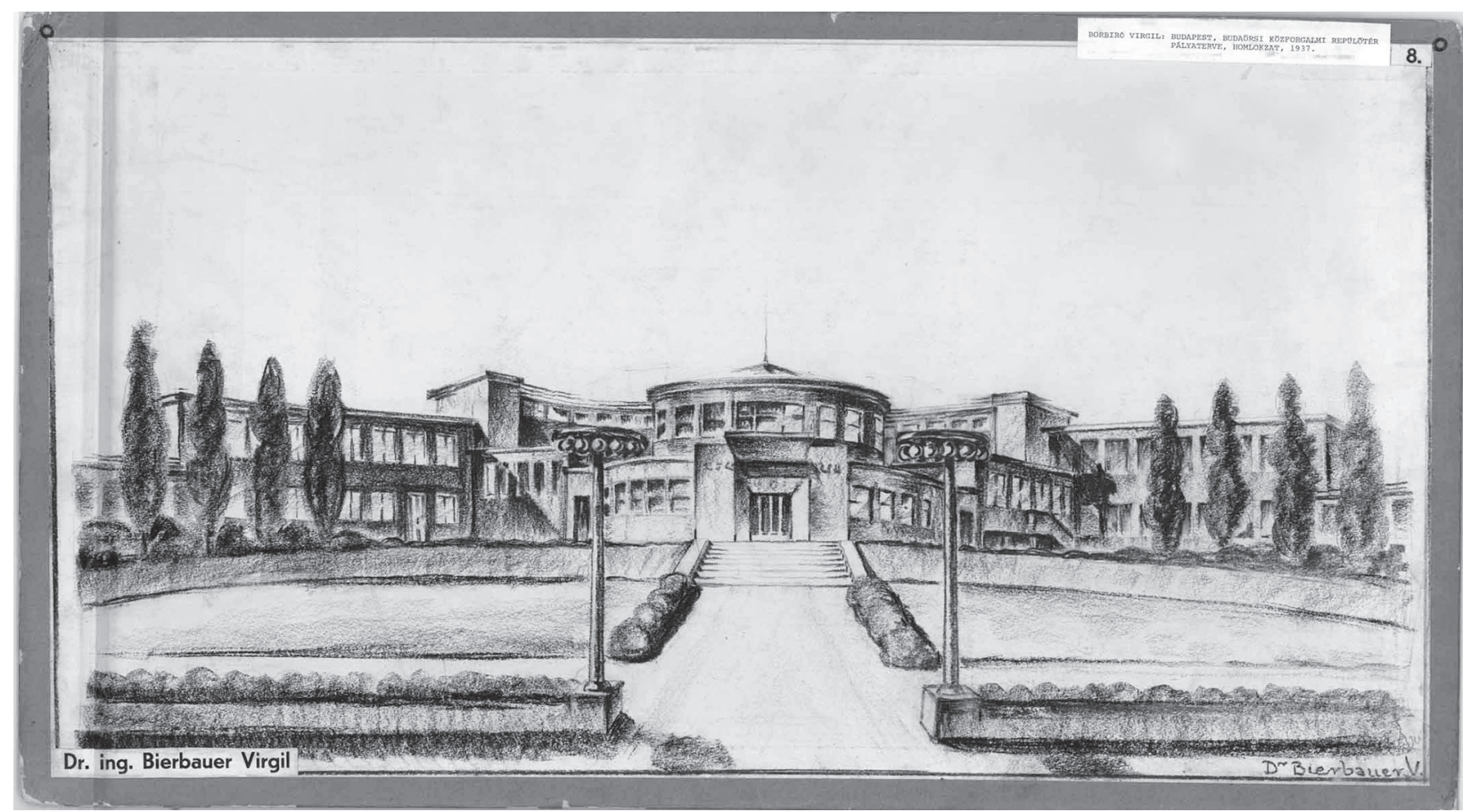

Fig. 30. Virgil Bierbauer: Competition entry for Budaörs Public Airport, Budapest, projection drawing of the front elevation, 1937; cardboard, charcoal, $39.5 \times 71.3$ cm (MÉM 69.013.2) 


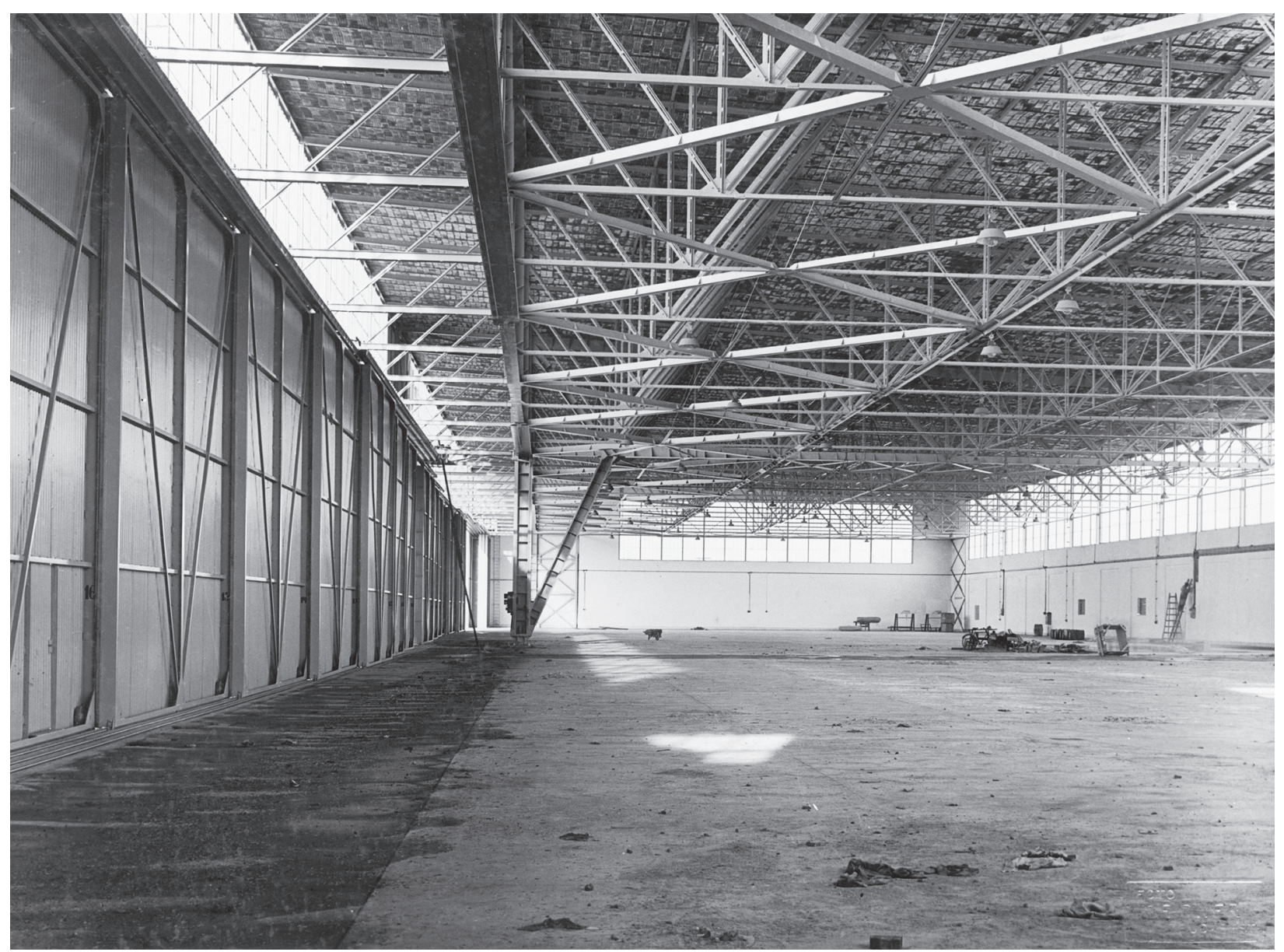

Fig. 31. The interior of Budaörs Airport's large hangar (photo: Zoltán Siedner, 1937; MÉM)

a map showing how the area was parcelled out, and designs for a sport association hotel planned in the vicinity [György Masirevich Jr (1905-1989)]. ${ }^{88}$ The latter was never built, but it is clear from the plans that the intention was to expand the existing airport complex with further auxiliary buildings. Connected at a right-angle to the outer axis of the modern, oblong, two-storey wing of the building was to be another wing, curved at the end and lit by windows all around, which, according to the inscription on the drawing, was intended as a lecture hall for pilot training. The site plans were made at different stages and to varying degrees of detail, and two of them present an overview of the entire area. All of them are related to the planning permission drawings. In addition to two large hangars and several small hangars, other airport buildings are also marked; the connections with the railway and road are also shown on a diagram that indicates the distance of the signalling equipment and the transport features, the height parameters, the outlines of the runways and the concrete apron (aircraft parking area), and the directions of take-off and landing
(Fig. 32). The third site plan is special in that it shows a proposal, not seen anywhere else, for how the area around the new building would be arranged. On one side of Köérberki Way, which forms the axis of symmetry on the drawing, can be seen the airport building, while on the other side is the floor plan of a similarly bow-shaped building (the officers' residence). Each building has a car park in front of it, maintaining the same symmetrical ratios. The drawing also shows the ramp leading up to the terminal building, necessary because of the height difference between its roadfacing and runway-facing sides, the twin stairways leading up from the car park, the walkway from the suburban railway station, other lines of steps, and a planned new road running perpendicularly to Kóérberki Way. The edges of the green, parkland areas are also marked, as are the planned directions of traffic, but not the runway, nor its associated buildings, nor the hangars.

The technical plans for the building show the solutions approved and agreed upon in detail by the architects, and also contain the changes requested 
by the client. The most important change was to get rid of the tunnels that Bierbauer had planned, leading from the side wings of the building to the aircraft, although the side wings and the central circular building remained the chief structural components of the overall design ${ }^{89}$ (Fig. 34).

By the time Bierbauer came to prepare the planning permission drawings, he had learnt some new information that he could now incorporate into his design. The main developments involved a cascade arrangement for certain upstairs levels, improvements to the way passenger traffic was organised, and innovations in the decoration of space. Bearing in mind the results of a system devised for large Western European airports, Bierbauer formulated a concept of passenger organisation whereby passengers passing through the reception vestibule would not cross the path of their luggage. What this meant in practice was that passengers would hand over their luggage to the baggage handlers immediately upon arrival, through a side entrance; after being weighed, the luggage would pass down a slide to the ground floor, where it would be transferred to the inspection rooms on the runwayside of the basement. In 1936, the architect wrote about the system of baggage and customs handling in the basement, taking place on a different floor from where the passengers were circulating: "With this solution, seen from the large waiting hall, passengers can grasp the entire airport in a single glance. Milan Airport is under construction in these months following the same principle, and the terminal building of the forthcoming second airport in Warsaw will be built under the influence of the plans for the new airport in Budapest, designed by myself in collaboration with László Králik."90

Bierbauer gave a lot of thought to relocating the restaurant, whose role was eventually much less prominent than the one planned for it in the competition entry. The service areas were located in the south wing, while the pilots' accommodation was in the north wing; above the restaurant was the command headquarters. As a result of the forced changes, the central building was raised by one extra storey: the basement was now devoted to everything to do with baggage handling, while the passenger traffic was now on the first floor. This allowed the circular shape of the central building to be maintained while liberating it from all the facilities that had originally cluttered it up (Fig. 35). In addition, the bow-shaped building was divided into two separate wings, which were now attached to the central round building. Internally, the straight line taken by passengers towards the runways stayed unchanged, but the restaurant was removed from its central position within the overall organisational structure.

When drafting his competition design, Bierbauer had taken the lessons of European precedents into consideration in particular when devising the crucial elements of the airport. Although he constantly monitored developments across Europe, he wrote that he only became aware of certain projects after he had already submitted his entry. Among them were Birmingham Airport, Le Bourget, and Milan Airport (he only saw the latter at the Sixth Triennial in Milan in 1936), as well as the designs for London Gatwick, which appeared later in the press. Consequently, as Bierbauer himself once wrote, he had to rely on what he had learnt on his study trips, and he modelled functional elements of the terminal building on the activities taking place there. He therefore determined four main units of the airport: passenger traffic; the restaurant and hotel section; the air mail area; and finally the commercial and technical management of air traffic. He drew up a functional schema based on his own structural model, showing the routes taken by the passengers and by those involved in other activities, which ideally had to avoid the former. The simplest route for the passengers, he decided, was a straight line from entrance to exit (and vice versa). He had seen the first European precedent for this at Croydon, but in order to be able to organise passenger traffic more efficiently, he imagined a space "with depth" - the central reception vestibule - in the shape of a circle, influenced by an imaginary centrifugal force associated with the circulation of passengers. Using this concept, he placed the waiting passengers in the middle of the central space, separating them from other activities (offices, baggage handling, etc.) with a single team of control and support staff; he also separated arriving passengers from departing passengers. Bierbauer pointed out the airports of Berlin Tempelhof, Munich and Hamburg as counterexamples, for the positioning of the passenger hall, perpendicular to the optimal straight line, resulted in substantial congestion and a "circulation vortex." Recognition of this fact led to the reconstruction of several European airports (Berlin, Cologne, Dresden, Birmingham) in the 1930s; the key question behind the reorganisation of airports was how to solve the needs of passenger traffic. Among the solutions Bierbauer mentioned was the use of underground tunnels leading to the aeroplanes, telescopic boarding corridors, and covered halls that 
the aircraft could taxi into. As an example of a combination of these solutions, he highlighted the concept of Francis Keally, who arranged the aeroplanes around a circular terminal building placed in the centre of the airport, bringing passengers to and from the building via underground passageways.

The construction of Gatwick Airport (Hoar, Marlow and Lovett, 1936) - a very close parallel to

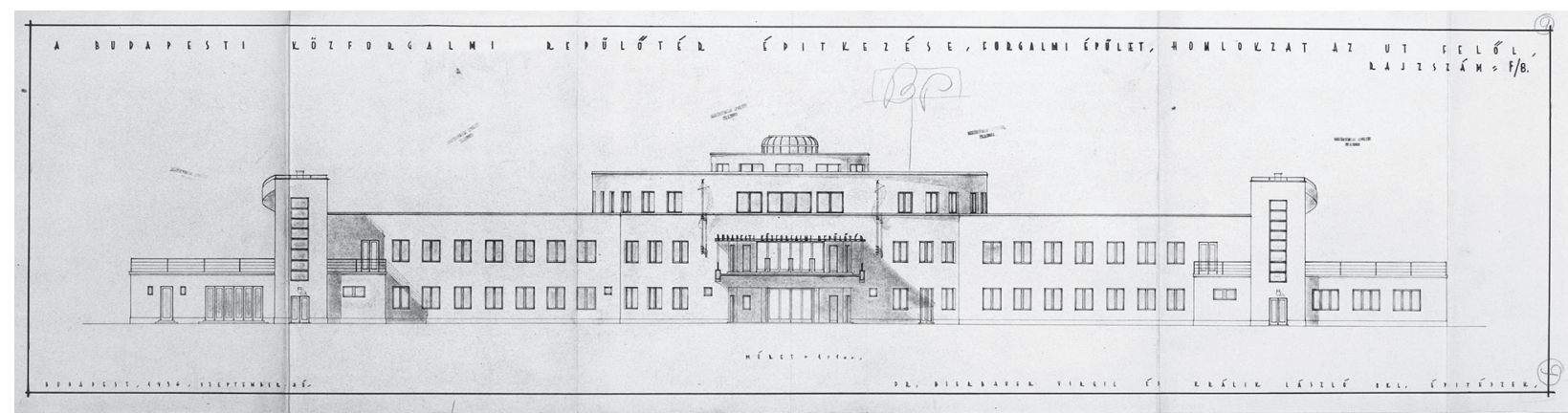

Fig. 32. Virgil Bierbauer and László Králik: Contract documents of Budaörs Public Airport, elevation facing the road, 1936 September (HIM Katonai objektumok építési anyaga: VII.244/20.doboz)

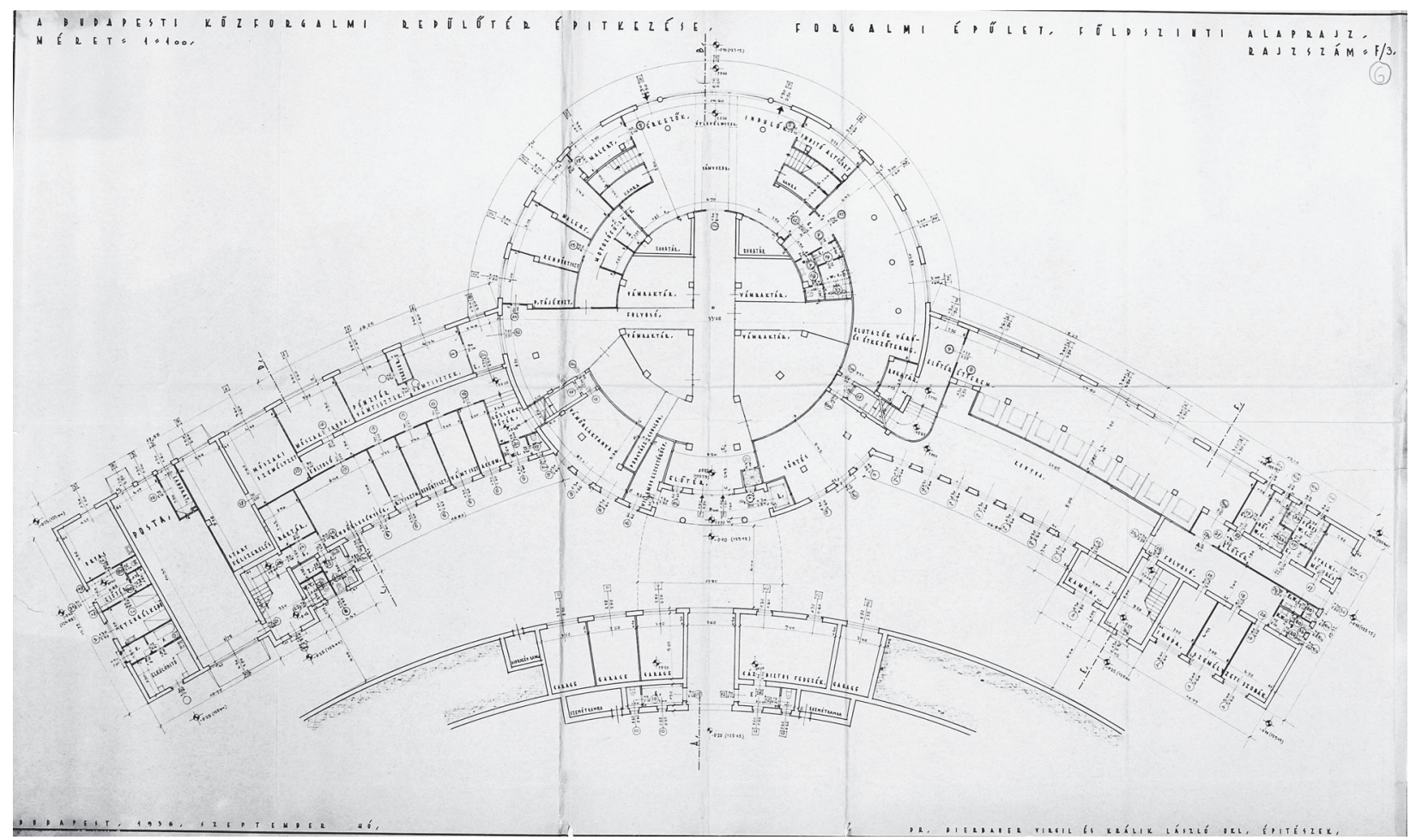

Fig. 33. Virgil Bierbauer and László Králik: Contract documents of Budaörs Public Airport, site plan / ground plan, 1936 July (HIM Katonai objektumok építési anyaga: VII.244/20.doboz)

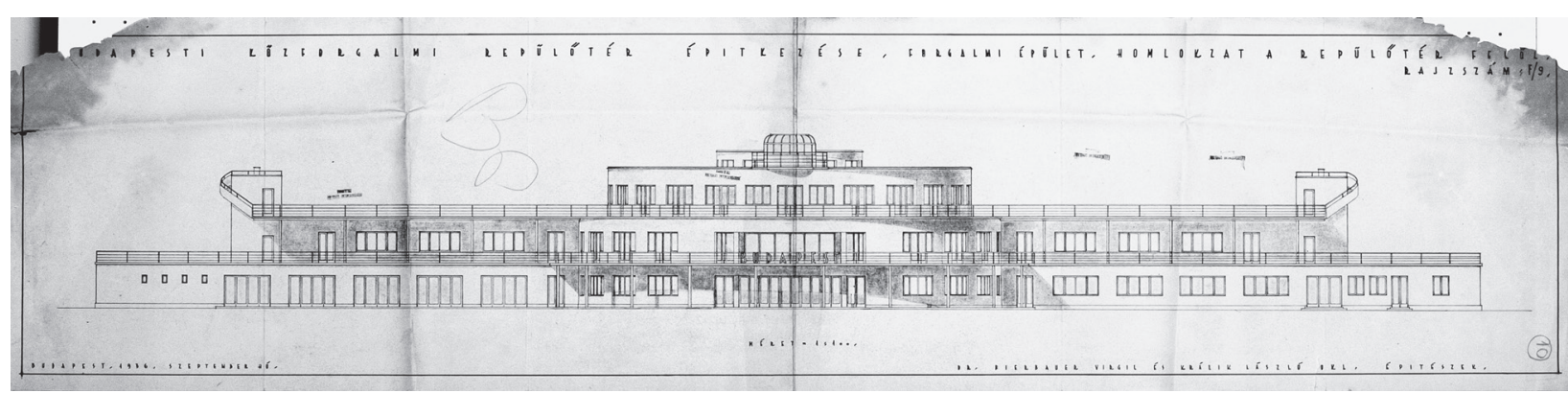

Fig. 34. Virgil Bierbauer and László Králik: Contract documents of Budaörs Public Airport, elevation facing the runway, 1936 July (HIM Katonai objektumok építési anyaga: VII.244 /20.doboz) 
Budaörs Airport - resulted in a similar solution. Here, the exit corridors towards the telescopic boarding arms led away from a circular corridor. When reworking his design for Budaörs Airport, Bierbauer used the English concept as a direct precedent because it was the closest parallel he could find for his own round central building. Arriving passengers passed through an underground entrance to reach the terminal building, the middle of which was occupied by shops. Around the outside of the corridor that encircled the shops were restaurants and offices, with the police and customs office behind them. Besides having a circular shape, the terminal at Gatwick also resembled the one at Budaörs in that it had overhead lighting, and the services (technical staff, weather and news services) and control functions (command headquarters, control tower) were located upstairs. There was a significant difference in that the flow of passenger traffic was arranged in accordance with a different logic and organisational principle. We can assume that Bierbauer's concept was influenced by both ideas.

\subsection{The finished building (Figs. 35-40)}

Work on constructing the new airport began when the instruction was issued by the Ministerial Council on 12 October 1935, ${ }^{91}$ and the architects' concept took shape more or less in line with their plans. The central, three-storey terminal building has a circular floor plan and a façade that is divided multiple times; attached to it at oblique angles on each side are two-storey wings, each bending slightly away from the runway, with open terraces (Fig. 37). In the right-hand wing were located the premises for passengers and visitors, the restaurant for transit passengers and the hotel, while the service rooms were located in the left-hand wing. The command headquarters and the offices for the radio and meteorological services remained in the main building, in the second-floor offices around the upstairs gallery overlooking the central vestibule. In 1948 Bierbauer (having meanwhile changed his name to Borbíró) wrote about the practical reasons for placing the side wings at an angle, away from the runway: "Bending the wings back from the airport-facing side was justified primarily by reasons of aviation, so that the shadow cast by the building would lie as far back as possible. We had to build ramps up to the first floor so that passengers arriving by motor vehicle could reach the entrance, while deliveries could be made beneath the ramps. The glass canopy above it served as the building's gesture for welcoming passengers. Beneath it, the broad glass doors allow a glimpse into the complex of interconnected and divided inner areas, illuminated by light streaming in from above and from the sides." 92 The façade of the round building cascades down towards the grass runway, while the upstairs levels have open terraces ringed with railings. The central segment has broad glass doorways on both the ground-floor and first-floor levels; on the first floor the doorway is placed back from the plane of the façade. On the ground floor the metal-and-glass doorway leads directly onto the concreted area in front of the runway. The regularity and symmetry of the windows, which mostly have four vertical panes, is broken on the second floor, where the office windows are closer together. The control tower located above the top storey was built entirely out of steel and glass (Fig. 38). An internal iron staircase led to the commander's station, which was surrounded by an observation station, protected with railings all around the outside, offering uninterrupted views in all directions. The observation station juts out from the façade of the topmost storey due to its base plate being placed slightly forward. The side wings are both two storeys in height, and their runway-facing façades have open terraces upstairs. The upstairs terrace is supported by circular columns.

The closed façade on the road-facing side of the building is quite the opposite of the runway-facing façade. The main entrance, with its canopy, is located along the central axis of the round building, and is connected to the road via a car ramp that curves down longer than the wings of the building on both sides. This means that the main entrance opens onto the first floor of the airport terminal, the same level as the central vestibule. Next to the ramp, close to the main entrance, are two stairways leading up from the car park. The side wings on this side of the building feature rows of symmetrically arranged double windows, and apart from three four-part windows above the broad entrance portal, this arrangement continues all around the surface of the cylinder. At the end of each side wing is a block-shaped stairwell with high windows piercing its central axis; these stairs lead up from the outside to the roof terraces, which are surrounded by parapet walls, and connected via a balcony that goes around the top floor of the circular building.

The ground-floor arc of the terminal building housed the inspection offices and partly the restaurant for transit passengers. The side wings each had two ranges of rooms, with the ones facing the runway 
opening directly onto the concrete apron. There were three places providing refreshments for passengers and visitors on the ground floor: a public establishment in the right-hand (north) wing, a transit room and saloon located in the right-hand lobe of the round building, and a large canteen beside the entrance. The opposite wing comprised the rooms for the officials and the technical staff, and those for the police and

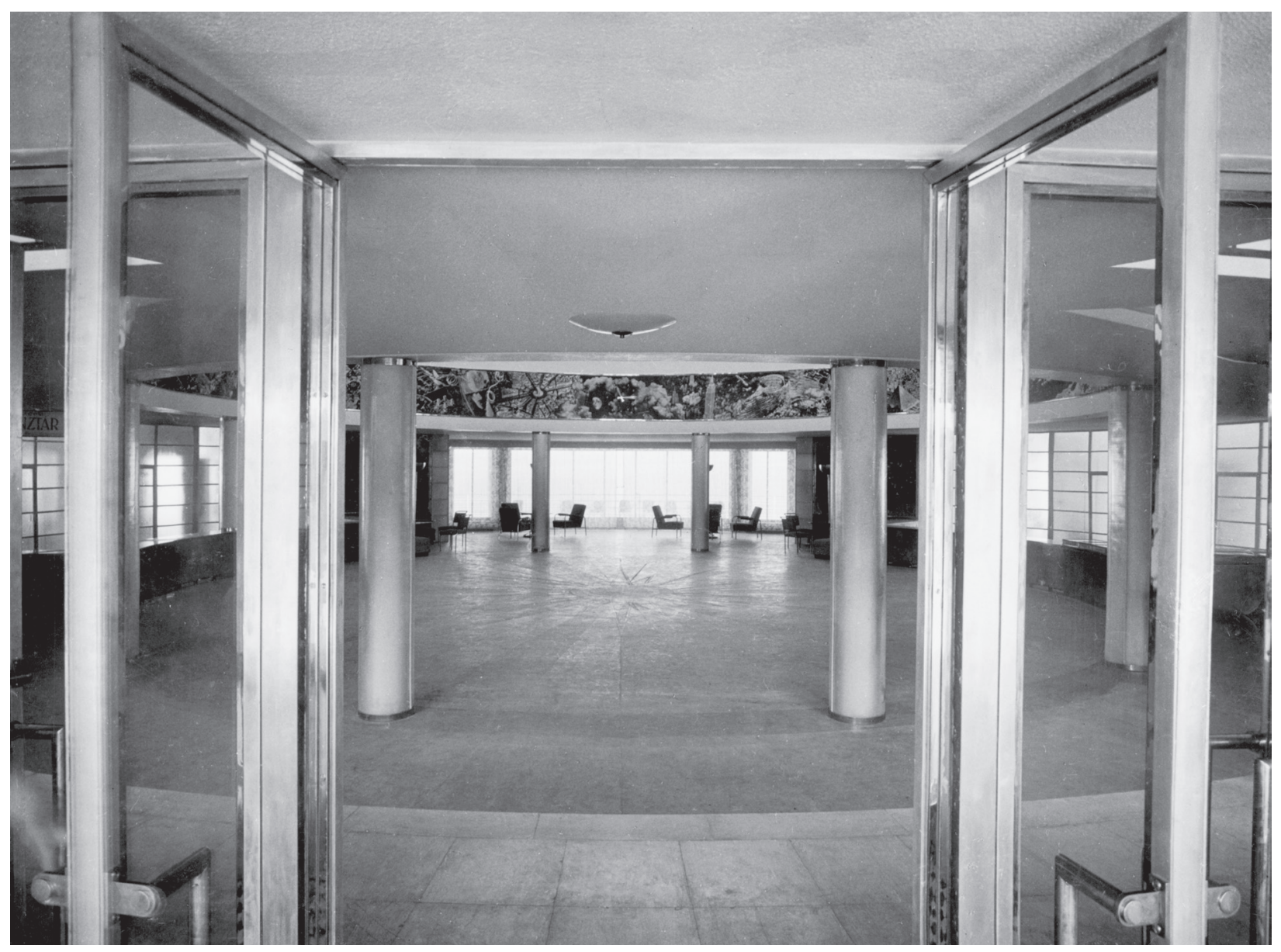

Fig. 35. The waiting room of Budaörs Airport's terminal building

(photo: Mrs Elemér Marsovszky, Belvárosi Fotómúhely, 1937; MÉM Borbíró-hagyaték GYN: 659. 21. doboz)

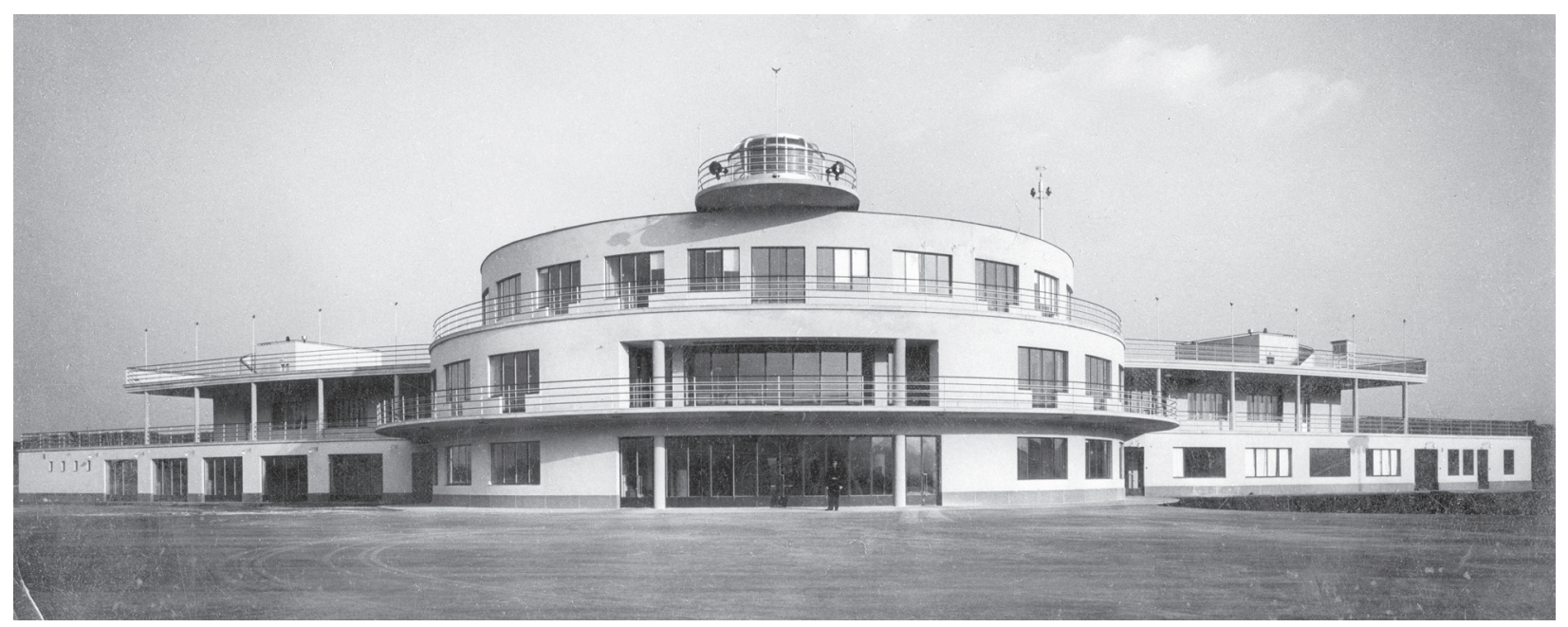

Fig. 36. The façade of the waiting room of Budaörs Airport's terminal building toward the runway (photo: Mrs Elemér Marsovszky, Belvárosi Fotómúhely, 1937; private collection; published in Tér és Forma 10. 1937: Budapest 1937. 213, and in Moderne Bauformen 1938) 


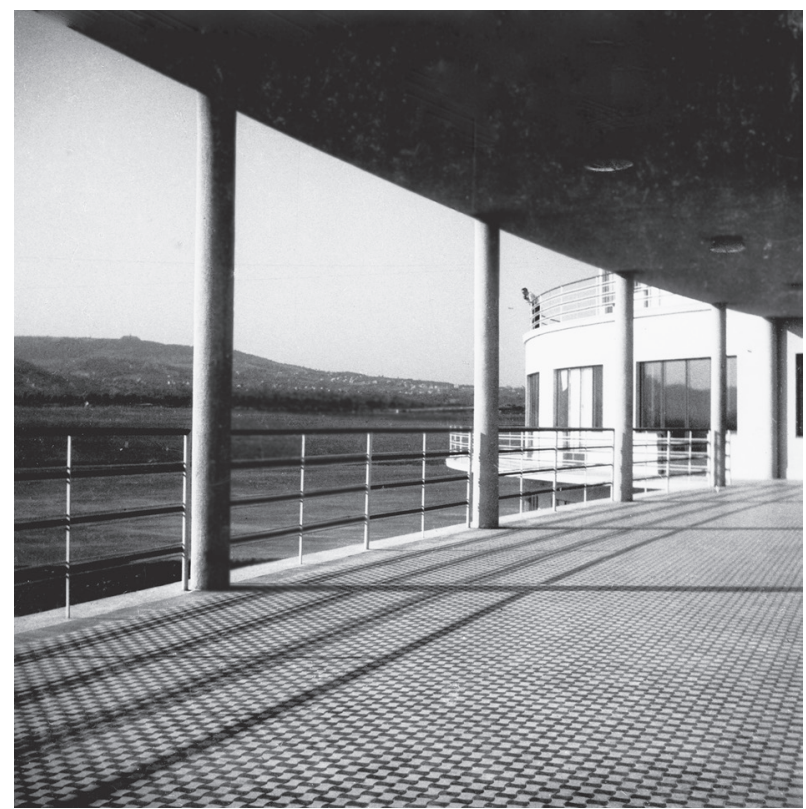

Fig. 37. Terrace details of Budaörs Airport's terminal building (photo: Mrs Elemér Marsovszky,

Belvárosi Fotómúhely, 1937; MÉM Borbíró-hagyaték GYN: 659. 21. doboz)

customs officers (Fig. 39). Further offices were located in the left-side (south) range of rooms in the round building, while the central area housed the customs warehouses; passport control and customs was carried out next to the doorway leading out to the runway. This point could be accessed from two directions via two sets of steps connecting it to the reception vestibule, and was used for handling both departures and arrivals. The rooms furthest away from the centre were maintained for the medical and postal services.

On the first floor of the building, visitors were received through the main entrance, accessed via the ramps or stairs, and departing passengers were led out at the opposite side, down to the runway via the aforementioned two sets of steps. On each side of the main entrance there is a set of return stairs leading up to the second-floor gallery, surrounded by service rooms and hotel rooms, meaning that the second floor was used by both staff and guests. The airlines had their offices in the segment of the terminal building facing the runway, which was split by the broad glass surface of the terrace windows. There are also two ranges of rooms upstairs in the side wings, and those on the runwayfacing side make up the open terrace. The right-hand wing had a hotel with four rooms, two bathrooms, a serving room, a food lift and a room for the servants. Passengers could be pampered in the two hairdressers' salons that were connected to the hotel and to the stairwell. The upstairs rooms in the left-hand wing

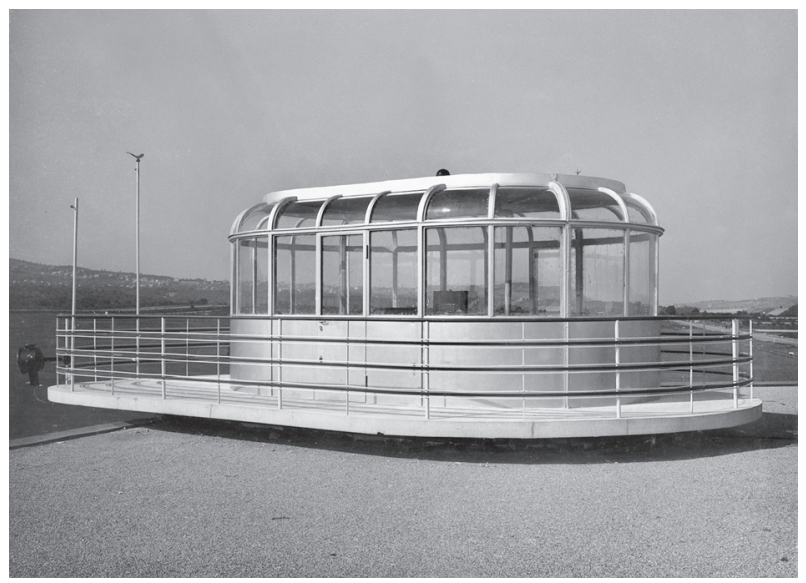

Fig. 38. The control tower of Budaörs Airport (photo: Mrs Elemér Marsovszky, Belvárosi Fotómúhely, 1937; MÉM Borbíró-hagyaték GYN: 659. 21. doboz published in Tér és Forma 10. 1937: Budapest 1937. 227)

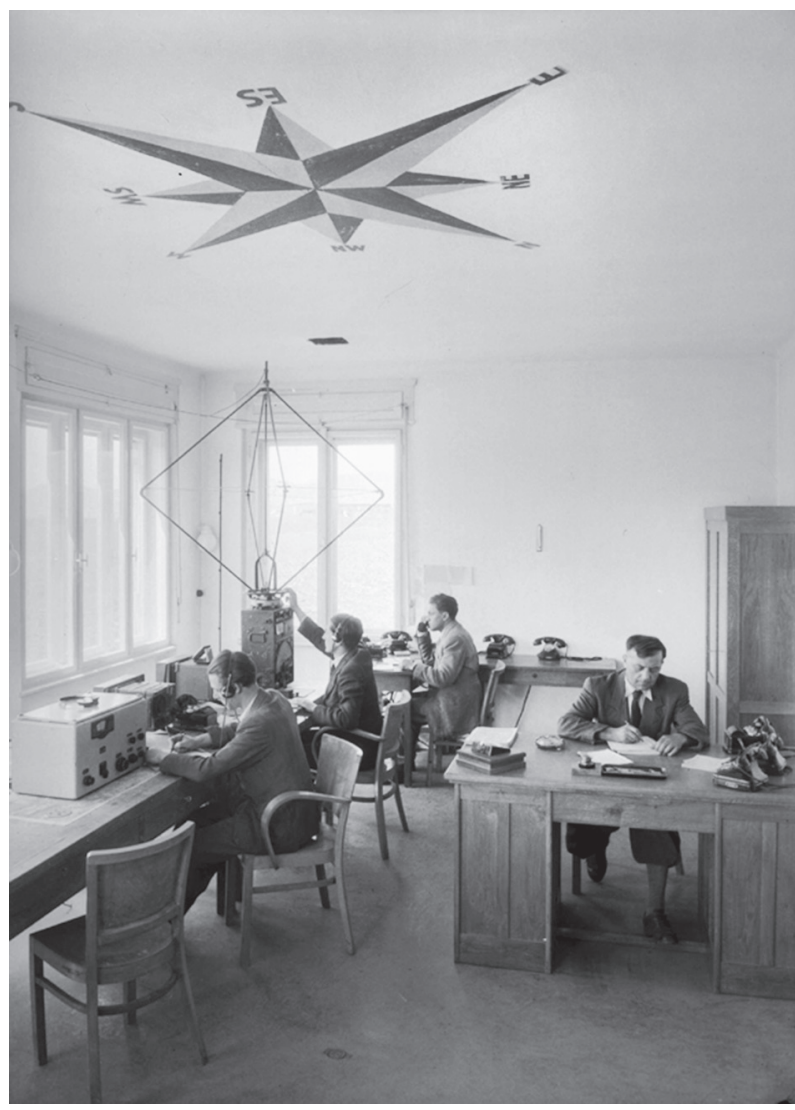

Fig. 39. Service room at Budaörs Airport (photo: Béla Hollenzer, 1946; BTM Kiscelli Múzeum 56.8.28)

were arranged in a mirror image of those in the other wing and accommodated the pilots. We should note that Bierbauer had in mind amateur pilots, both men and women, who were expected to stay here during a weekend's flying, presumably from abroad; even in the competition design, as mentioned above, a separate section was set aside for such visitors. 


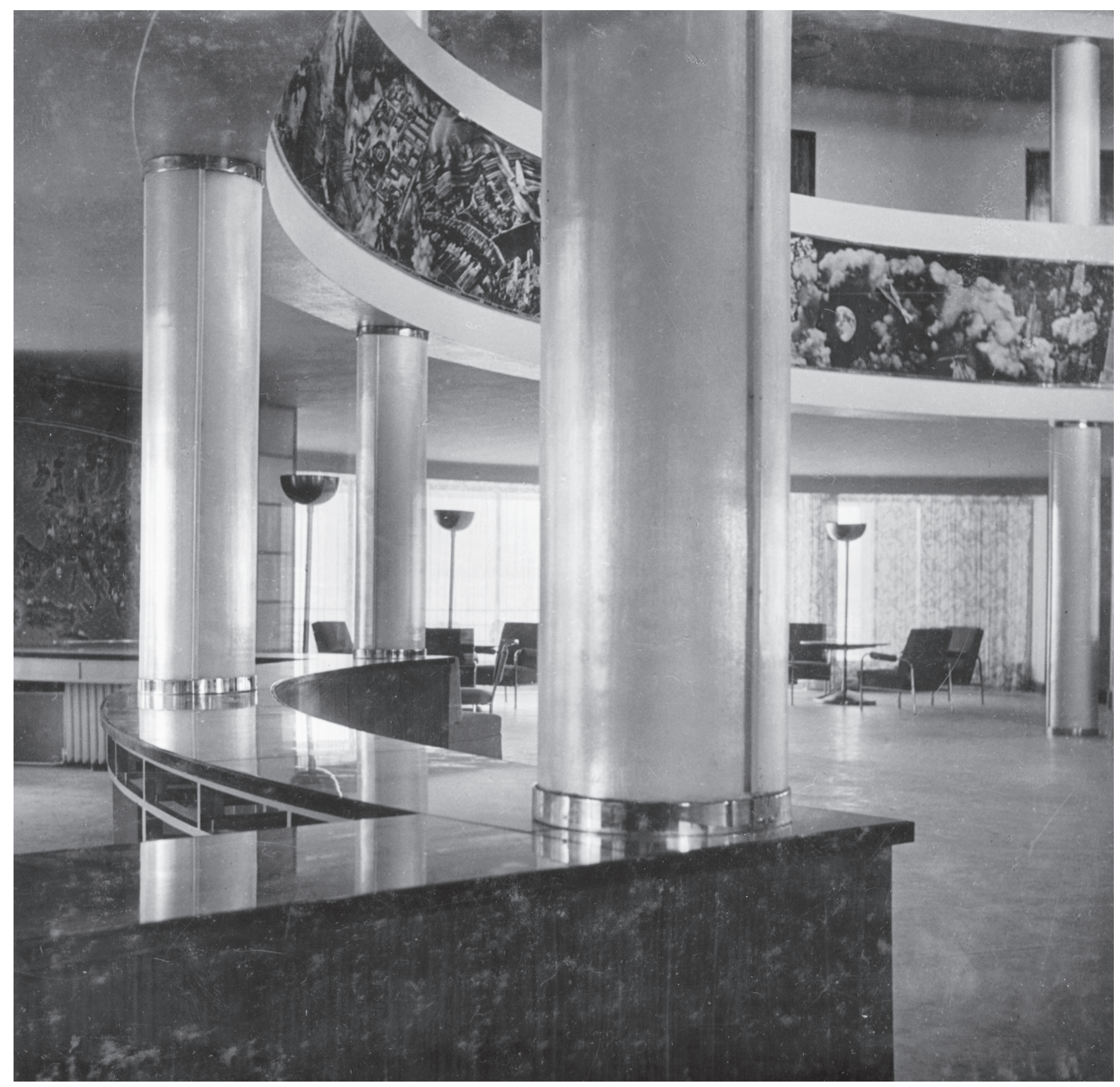

Fig. 40. Details of Budaörs Airport's waiting hall with columns covered with glass mosaic (photo: Mrs Elemér Marsovszky, Belvárosi Fotómúhely, 1937; MÉM Borbíró-hagyaték GYN: 659. 21. doboz; published in Tér és Forma 10. 1937: Budapest 1937. 221)

The cylindrical building's rich variety of form was provided by the cascading arrangement of its curving façade towards the runway, which enabled the broad, covered terraces to be constructed all around the first floor. There was no direct access to the runway from the central vestibule on the first floor. Instead, there were glass windows reaching up to the ceiling that gave visitors a clear view of the airfield from the airport entrance. The circular hall contains a ring of twelve cylindrical columns which support the balustrade on which the cyclorama was placed. Following the principles of minimalism, concealed lighting was used, although during the day natural light was allowed to shine in through the terrace windows and through the ring of windows placed around the circumference of a wide but shallow drum-shaped elevation located above the ceiling.

Arranging the rooms in the building logically and rationally was a task that Bierbauer regarded merely as the first step. He also believed that visitors had to be introduced to the visual world of flight. To do this, he not only relied upon the enthralling pleasure derived from the transparent space, but also conceived of an artistic decoration, on the theme of aviation, that 
would fulfil some kind of propagandistic role. The architect was clearly very interested in the characteristics of humanity. He consciously formed a link between the special experience of travel, in particular flying, with the human imagination and desire for adventure, and the latest in modern technology. Architecturally, he provided a panorama by leaving a gap in the wall around the reception vestibule (beneath the balustrade - photofresco - of the gallery), which he filled with a broad expanse of glass overlooking the landscape outside. This also gave a new perspective to the reception hall itself. The role of the interiors was increased by having a single large space where passengers could not only check in but also prepare themselves while they waited for their flight. The architect's intention for this waiting room is best expressed in the following excerpt: “... using frugal means, but with flair, this hall has been given an appearance which, by virtue of its uniqueness and artistic character, and with the spectacular frames with which the space itself is handled, makes it original and stylish." 93 Within the circular interior, the columns supporting the upstairs balustrade, the decorative balustrade itself, the glass skylights, the panoramic windows overlooking the runway and the colourful flooring constituted a spectacular and unified whole, which also included the furniture and other fittings. The semi-cylindrical support columns were also decorated with special bent cord-glass panels in cool colours, whose silvery crystalline effect gave an airy sparkle to the space around it (Fig. 40).

Contemporary photographs also show that the cyclorama of "The Experience of Flight" dominated the entire waiting room and was the most spectacular visual component of the vestibule. At the time it was made, avant-garde tendencies had settled down somewhat, and two decades had passed since the arrival of Futurism and montage - both with undisputable influences on the cyclorama. ${ }^{94}$ Nevertheless, the general public was taken aback both by the theme of the work and by its method of execution. For a short while, the greatest "mental resistance" and amazement was prompted by the fact that the spectacle was not presented to viewers in a linear way, but in a condensed form, with neither a beginning nor an end, in the traditional sense of a narrative, and with the landscape details interwoven in an equally unconventional manner. Standing in the middle of the vestibule and looking up, the viewer could enter the 360-degree flow of imagery at any point, focusing on any one of the hundreds of pictures, and could leave again when-

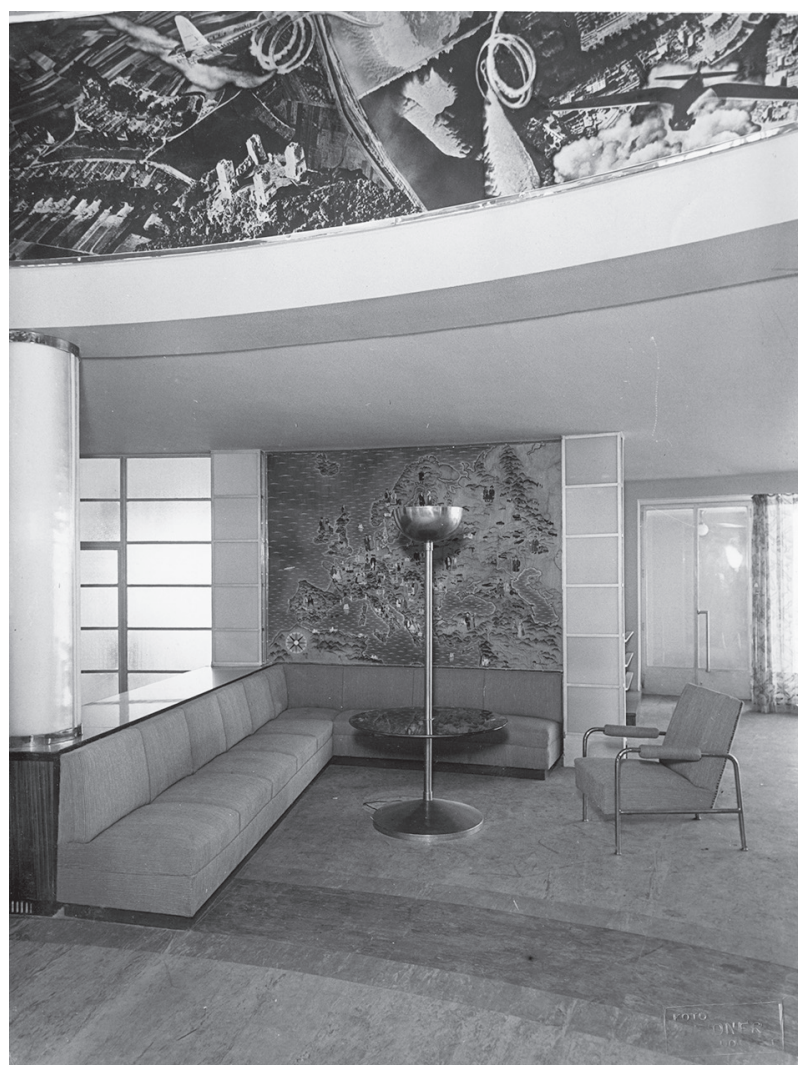

Fig. 41. The waiting room of Budaörs Airport's terminal building with the detail (Diósgyôr Castle) of section XII of the cyclorama "The Experience of Flight," and with the map of Europe

(photo: Mrs Elemér Marsovszky, Belvárosi Fotómúhely,

1937; MÉM Borbíró-hagyaték GYN: 659. 21. doboz)

ever they wished, without any of the effort invested in interpreting the spectacle going to waste.

There is no precise information available to us about the furniture upholstery or about the colours used on the maps specially painted by István Pekáry (1905-1981), all of which formed part of the overall interior design concept (Fig. 41), but there can be little doubt that Pekáry's map of "Greater Hungary" (that is, the Kingdom of Hungary before the end of the First World War), decorated with folk art motifs (Fig. 42), and Mrs Marsovszky's modern photomontage (Figs. 3, 40, 54, 90, 100), were placed side by side as a kind of political message expressing the "spirit of the age." This brought together both the national, ethnographic sentiment of Hungary and the internationalist philosophy of airports as meeting points for differing cultures. This delicate balance of styles shines a light on the problem of functionalist architecture and on the cultural differences that inevitably manifested themselves even with a supposedly international style. András Ferkai regards this as the reason for the diver- 


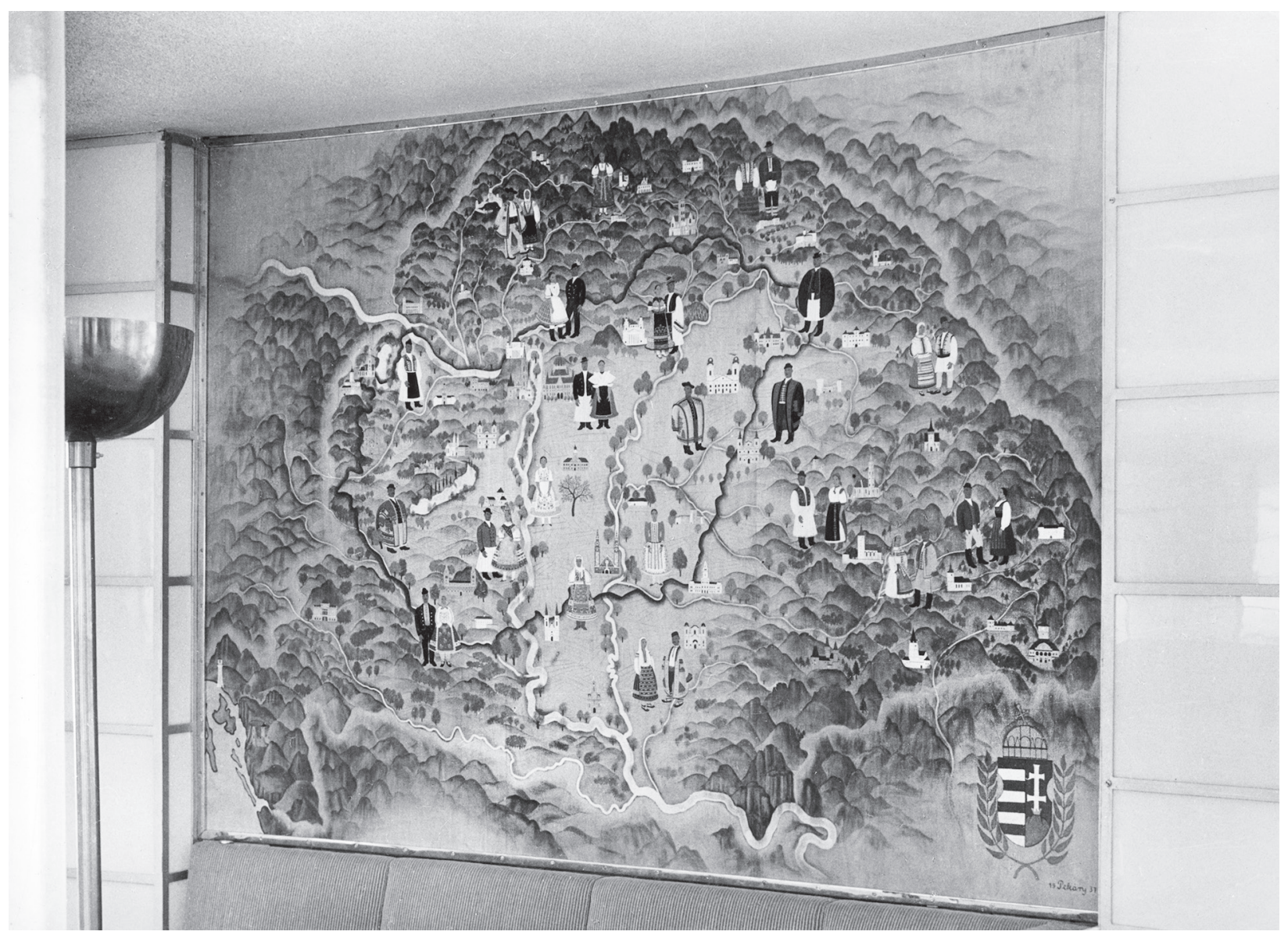

Fig. 42. Map of Hungary at the Budaörs Airport's waiting room, István Pekáry

(photo: Mrs Elemér Marsovszky, Belvárosi Fotóműhely, 1937; MÉM Borbíró-hagyaték GYN: 659. 21. doboz)

sity in modern approaches. ${ }^{95} \mathrm{He}$ also notes that one of the distinctive aspects of modernism in Hungary can be traced to an exaggerated and artificial use of functionalism and an excessive lack of home-grown avant-garde endeavours, which was partly due to the fact that the modern architectural style reached its peak in Hungary in the 1930s, just as the avant-garde momentum was beginning to fade. Bierbauer also took an interest in what lay in the background of the differences between the nations. Where architecture was concerned, he deemed it possible to express the hallmarks of the national character in the formation of shape and mass, but he regarded the discrepancies as being dependent on style and mentality. Thus, he attributed the predominance of longitudinal passenger halls in Northern European airports to the simpler way of living in that part of the world, ${ }^{96}$ in contrast with the Hungarian style, which in his view was characterised by "the friendly cheerfulness of life and the openness of hospitality." ${ }^{97}$ Budaörs Airport had a much smaller area to cater for guests than earlier precedents abroad. As the proportion of travelling passengers did not justify the construction of additional viewing areas and terraces, Bierbauer focused on making facilities for the travelling elite as comfortable as possible using the tools of architecture. His ideas on modern aesthetic interiors can be clearly felt in a letter he wrote about the artistic aspects of his work of architecture: "Different experiences of space are lined up one after the other, the broad circular hall, the capacious waiting room, the terrace, the emerald-green airfield, the picturesque hills. Naturally, every architecturally created component is also needed for practical reasons: the circular hall is where passengers assemble and disperse, the meeting point for airlines and passengers, in front of which the open waiting room is equipped with comfortable furniture, while family and friends can see the passengers off from the terrace. This was all achieved through architectural organisation, elevating it above mere functionality into expressive artistic form. The individual components not only have a specific purpose, they also necessarily follow on from one another, even though they are arranged into a harmonious whole: the elementary nature and static calm of 


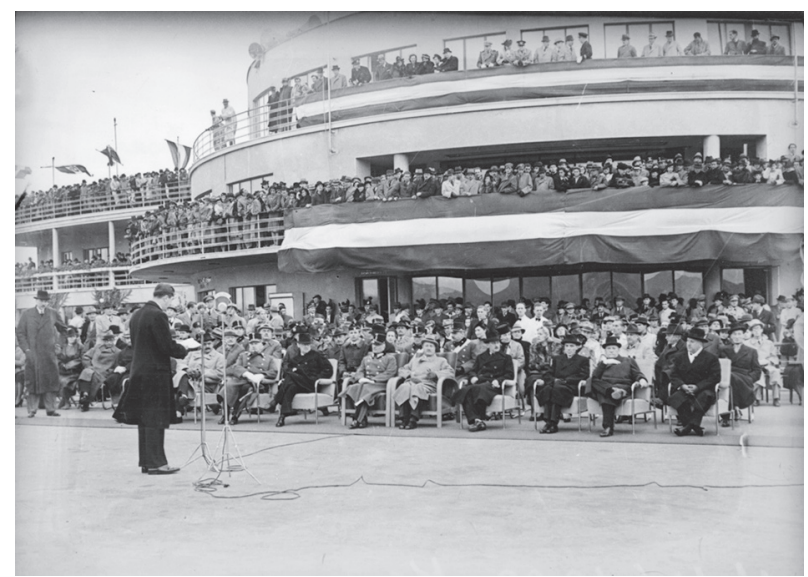

Fig. 43. Opening Ceremony of Budaörs Airport, June 20, 1937 (photo: MNM 1411-1963)

the circular space commands you to pause momentarily, but whereas an enclosed round space will always generate a certain spatial pathos, this does not take place here, because people in the waiting room are transfixed by the picture of nature that streams in through the enormous windows, virtually lifting them out into open air. The reality of this impression is intensified by the waiting aeroplane." 98 The planning process and the final, implemented concept reveals to us an arc of development that is founded on some substantial contradictions. Based on the original idea, the plans were drawn up with a far larger complex of buildings in mind, with a terminal building designed with reception areas and catering facilities capable of handling far larger numbers of people. This planning programme was later scaled back, but some of the ideas for supplementary buildings still survive, such as a hotel, and buildings for sport and training.

The capital city's new civil airport was officially opened on 20 June 1937 at a spectacular ceremony attended by a hundred thousand people ${ }^{99}$ (Fig. 43). The political message accompanying the new airport was underlined not only by the high-level state representatives in attendance at the opening ceremony, but also by the German and Italian guests who were officially invited, and by the military choreography of the aerial show presented to the foreign guests. ${ }^{100}$

Despite the fact that official communications always emphasised the central, regional role of Budapest, Budaörs Airport, built within the frames of a narrower programme of architecture, ended up as a transit airport. Based on its architectural qualities, however, it was regarded as among the finest airports of its day. Nestled in the southwest corner of the airfield, the terminal was unique with its circular passenger hall and the cascade of terraces that followed its cylindrical form. Topped off with its modern control tower and embraced by its curving side wings, the architects considered it unnecessary to add any further external ornamentation (Fig. 36).

\section{BIERBAUER'S FOREIGN CORRESPONDENCE RELATING TO THE AIRPORT}

The correspondence in Bierbauer's estate shows that he conducted extensive correspondence with his foreign fellow architects regarding questions relating to airport architecture. These professional contacts of his helped him to take decisions on numerous important matters, including the functions of the different rooms and their interior decoration. He did not make copies of his own letters, so we do not know exactly what they contained, although certain drafts of letters he wrote have survived, and we can also make inferences about the questions that concerned him from the answers he received. From his estate we know that the Royal Institute of British Architects in London sent him a copy of every report prepared by the Aerodromes Committee. ${ }^{101}$ Bierbauer wrote about how helpful this preparatory collection of information from abroad had been to him: "I paid particular attention to the differences that distinguish certain general European aspects of the plant from the administrative system that has developed out of local circumstances." 102 He was aware of the major international competitions, and he managed to obtain a copy of the summary study published by RIBA about the airports of the age. ${ }^{103}$ The European analogies that he mostly made use of and presented in his writings were those aimed at researching functional unity and decorative solutions. This meant that he was aware of the English technique of the photomural, regarded as the most up-to-date way of decorating modern buildings, as early as 1935, and he held consultations with the leading Italian Futurist artist, Marinetti, in 1936. One of his most important correspondents was the RIBA, and these documents reveal important details relating to the precedents of the photomontage. Particularly noteworthy is the letter sent to Bierbauer in December 1935 by H. S. Goodhart-Rendel, secretary of the RIBA with responsibility for exhibitions, in which the Hungarian architect is asked to send some photographs for the forthcoming architectural exhibition in 
London. ${ }^{104}$ From the correspondence between the two men it becomes apparent that Bierbauer had previously written to the Royal Institute, asking them for pictures of and information about Lichfield Court to publish in Tér és Forma. ${ }^{105}$ At the same time he inquired about the Brighton Embassy Court building, because this was the first building in the United Kingdom to have a vestibule decorated with a photofresco. This inquiry eventually brought him into contact with Wells Coates, the architect of Embassy Court (Fig. 44), whose letter dated 5 February 1936 tells us that Bierbauer's interest in the new English technique of the photomural had been piqued by some illustrations seen in Architectural Review at the end of 1935. ${ }^{106}$ Unfortunately nothing survives concerning Bierbauer's correspondence with the inventors of the photofresco, and all we know is that he planned to get in touch with them. On 8 February 1937 he once again wrote to Coates regarding the same subject, asking for specific information about the mural technique invented by Michael Egan and Eugene Mollo. This was the period when he was planning the montage for Budaörs Airport. Coates replied on 16 February 1937: "Dear Dr. Bierbauer, Thank you for your letter of the 8th February. I am interested to learn that you are requiring information on the special photo-mural technique I employed, for the first time, at Embassy Court, Brighton. I have sent a copy of your letter to Messrs. Mollo \& Egan, who carry out this work, and have asked them to reply to you direct giving you all the information they can. With best wishes to you. Yours sincerely, Wells Coates." 107 Bierbauer also mentioned his English contacts in his writings, and he published the following annotation to a detail of one of Coates's airport competition designs: "A contemporary airport design: the terminal building in the centre, with hangars on the side, and a slope leading down to the underground railway along the axis of the main building: a station underneath the terminal building. Designed by: Wells Coates."108

It is worth mentioning the correspondence Bierbauer exchanged with Georges Labro (architect of Le Bourget, Paris) and with M. H. Volk, an English aviation expert, at the time when Budaörs Airport was under construction and in the period after its opening. In the summer of 1936 Volk wrote to Bierbauer concerning the floor plan arrangement of the terminal building: "I have been carefully thinking over some of the details that you kindly showed me of your proposed designs for the Budapest Airport, and if I may I should like to mention one or two points which may be worth consideration, namely, (a) Whether

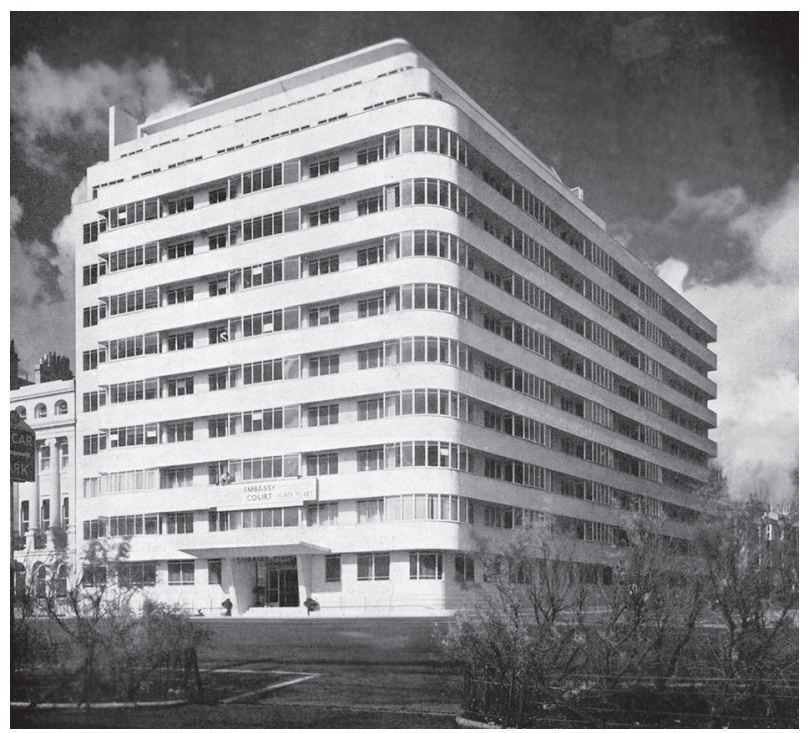

Fig. 44. The Embassy Court in Brighton, architect: Wells Coates (photo published in Tér és Forma 9. 1936. 121)

it is really wise to arrange for transit of the luggage of passengers using the Airport by a separate route other than that actually traversed by the passengers themselves. The reason I mention this is that it is a peculiarity of most people: particularly in these days of rapid transport: that they hate or at least do not like to be entirely separated from their personal belongings. (b) That the route from the point of arrival at the Airport by road i.e. the Main Entrance of the Administrative or Station Building to the awaiting Aeroplane via the Booking Hall and/or Customs, should be kept as short as possible. (c) Another point worthy of consideration is whether or not it would be wiser, as I now find is the generally accepted Continental practise: for the main Public Restaurant to be a separate building station or terminal building. Provision for passengers, travelling by air, to obtain light refreshment can be provided by a small buffet adjoining the Booking Hall."109 A few draft letters that survive in Bierbauer's estate give us an interesting glimpse into the correspondence between the Hungarian architect and Labro, who was working on the reconstruction of Le Bourget airport (Fig. 45). In a letter dated 4 January 1938, Labro asked for photographs and descriptions of the new airport, as well as copies of the plans, explaining: "I am currently preparing some general documentation on airports with a view to completing the finishing works of Le Bourget airport, and I would be happy to make use of your personal experience in this matter. I would be particularly grateful if you could inform me whether you believe that a hotel and a restaurant should have a place inside the airport 


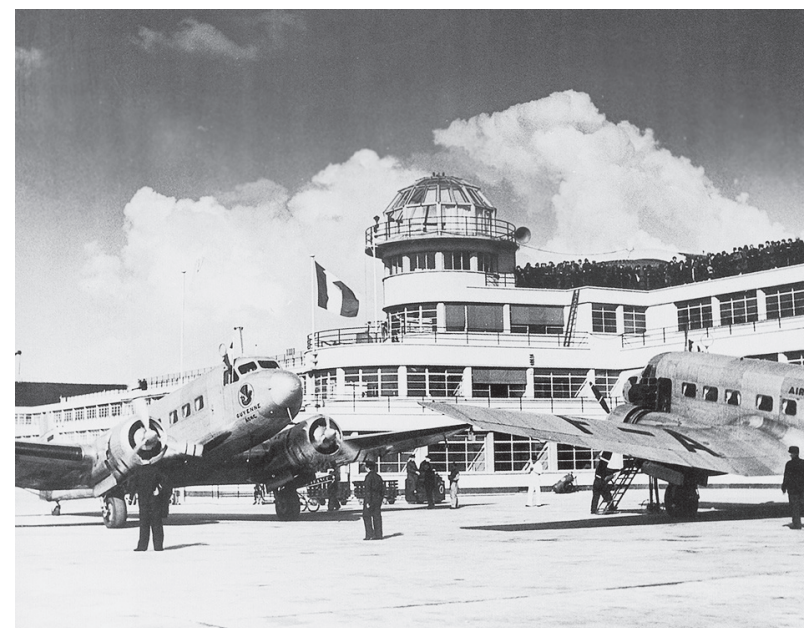

Fig. 45. Le Bourget Airport, Paris, 1936-1937, architect: Georges Labro (photo published in Zukowski 1996. 116.)

itself, and on which floor and in which part of your plan you have intended these two elements." 110 Bierbauer found out from Labro that an interesting article on completed and planned airports had appeared in the November 1937 issue of Design and Construction. As he was working on a similar project, he took the opportunity to request some photographs of the newly rebuilt French airport for an article he was writing, which was published shortly after these letters were written. ${ }^{111}$ In his answer to Labro's questions, Bierbauer justified his inclusion of a restaurant and a hotel inside the building by stating that Budapest's new airport was a transit airport. At the end of his letter he wrote, "Naturally, our financial situation did not facilitate a construction of a greater volume, but within our modest means we attempted to find the best solution, and I am delighted that it has, as you stated, gained your approval."112 Labro was presumably also interested in the interior decoration, because in his reply Bierbauer informed the French architect that he should request photographs from "Mme H. de Marsovszky," who would send him the required pictures in exchange for three pengôs per print. Bierbauer also sent him the special issue of Tér és Forma, and at the very end of the letter he proposed that they meet in person: "Departing from the airport in Paris in the morning, you would reach Budapest airport around 2 in the afternoon, where I would be waiting for you to discuss all those matters that we find interesting." 113 The attachments themselves are missing, but from the reply Labro sent on 17 January 1938 we know that he included both the November 1937 issue of Travaux magazine and a little collection of photographs of Le Bourget airport. In connection with the additional

\section{Auslands-Umsehan und Zeits YOD E R E BAUFOR Y EN / VERAG JUI I}

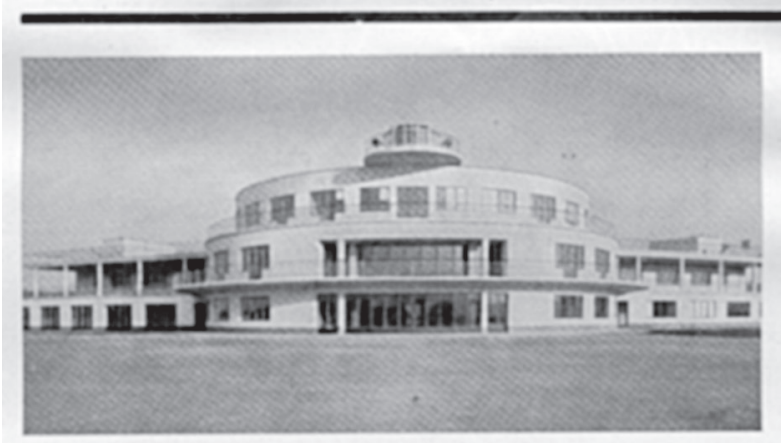

Cngarn: Das Emplangsgebdude des neuen Fughajens in Budapest. Archltekten V. Bierbauer \& L Krallk. Aus ter es forma

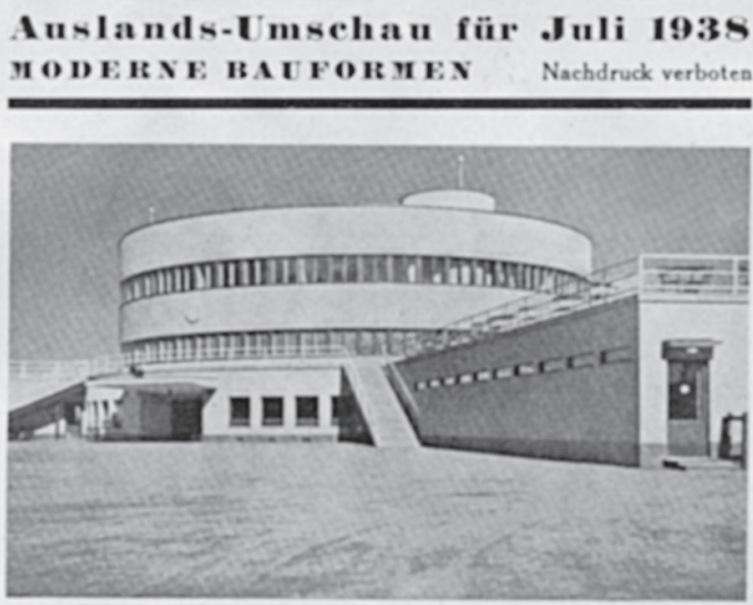

Vinniand: Das vom finnischen Staat errichtete Restaurantgebdude anf Aem erweiterien Flugplatz von Helsingfors. Entwurf: Staatshochbauter waltang. Aus . Arkkitehti"

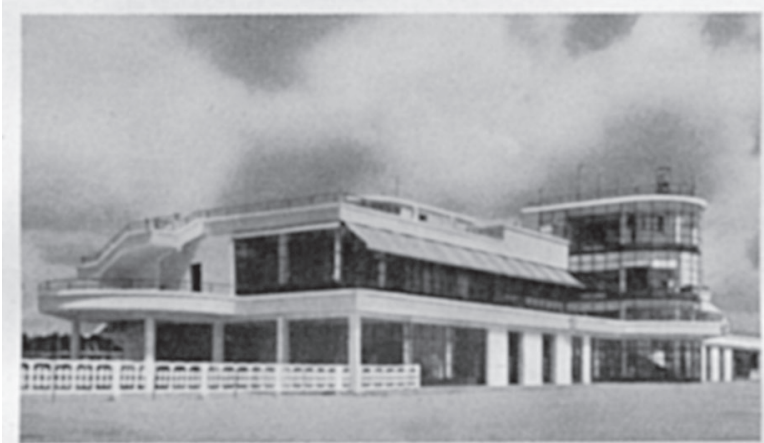

Vrankreieh: Auch Bordeaux erhielt einen neuen Faghajen. Architekt Alfred Duprat. Aus Deutsche Bauzeitung'

Fig. 46. Illustrations of foreign airports - "Ungarn, Finnland, Frankreich" (cutting from Moderne Bauformen 1938 in MÉM Borbíró-hagyaték)

planning tasks for the reconstruction of Le Bourget, timed to coincide with the Exposition Universelle, he wrote, "They will continue working on it for a long 
time to come, while the terminal building, which has enormous wall surfaces, still generates the impression of emptiness. This will cease when the illuminated signs for arrivals and departures are in place either side of the circular recess, together with the mosaicfresco with its symbolic representation of flight."114 The two men - to the best of my knowledge - never did meet, but their correspondence nevertheless is an excellent documentation of the importance architects placed on building contacts and exchanging experiences when it came to a new type of building that was still in its early stages of development, as was the case with airport terminals.

The exchange of information extended to sending each other periodicals and photographs. A year before Budaörs Airport was ready, Bierbauer asked Volk to send him photos of airports, although Volk, apart from a few private pictures he had taken himself, was unable to send him any, because the rights to professional photographs were owned by the periodicals and magazines ${ }^{115}$ (Figs. 46-47). Bierbauer's wideranging efforts at contact building bore fruit, however, because architects abroad learnt about the construction going on in Budapest, and Bierbauer obtained a wealth of new information in return. In the 1930s he exchanged letters with Eliel Saarinen, Alberto Sartoris, the Olgyay brothers, resident in Rome (Aladár Olgyay, 1910-1964; Viktor Olgyay, 1910-1966), Oszkár Winkler (1907-1984), Giuseppe Pagano, editor of Casabella, Agnoldomenico Pica, Richard J. Neutra, Jacobus Johannes Pieter Oud, and, judging by a letter from 1935, László Moholy-Nagy (1895-1946). ${ }^{116}$ Nigel Norman - whose name also appears in the report of his study tour in 1939 - asked Bierbauer for materials on the airport after visiting the building in person. ${ }^{117}$ Also of great importance were the requests sent to Bierbauer from specialist journals that published illustrated supplements. Among them were the magazines FLIGHT (London), SHELL AVION NEWS (London), SABENA (Brussels), EDITORIALE AERONAUTICA (Rome), FORUM (Bratislava), ARCHITEC-

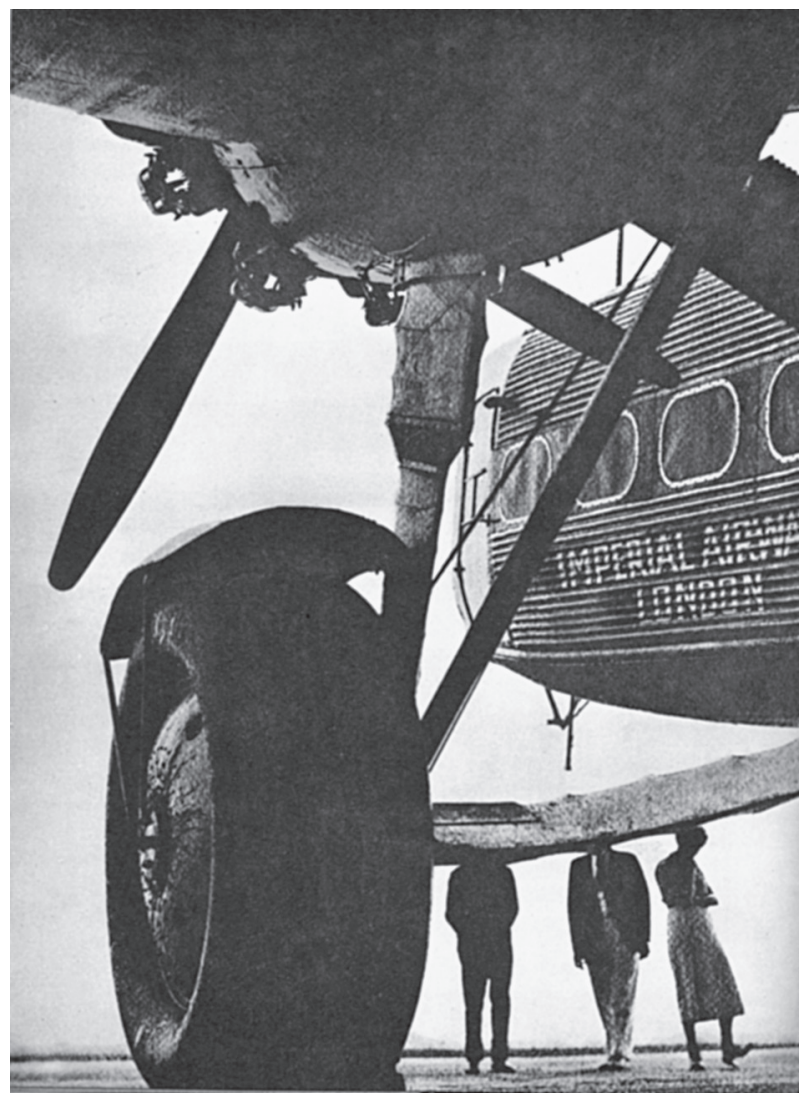

Fig. 47. Modern aircraft and its passengers (illustration from Le CoRbusier 1935. Fig. 30)

TURAL DESIGN and CONSTRUCTION (London) ${ }^{118}$ and Moderne Bauformen. ${ }^{119}$ Bierbauer sent a copy of the airport article from May 1936 in Hungary's Nemzeti Ujság [literally: "National Newspaper"] to the RIBA library for the purpose of archiving, ${ }^{120}$ and as well as articles, he also sent photographs abroad. Three original prints of the new airport (1938) that he gave to the Royal Institute are still held by their collection. ${ }^{121}$ This was not a unique gesture in those days, because there were several serious architectural collections that systematically sought professional photographs of the latest buildings. This is how a number of photographs by Mrs Marsovszky ended up in the Alberto Sartoris archive in Zurich.

\section{VIRGIL BIERBAUER'S AIRPORT CRITICISM}

The article that Bierbauer wrote titled "On the architecture of airports" ("Repülôterek építészetérôl”), published after the official opening of Budaörs Airport, is the most comprehensive Hungarian-language pub- lication on the trends and achievements of Western European airport architecture at the time. ${ }^{122}$ One of the main virtues of his study is that it investigates all the fundamental problems that need to be taken into 
consideration when designing an airport, illustrating them with examples acquired during his collection of materials or on his study trips. What is striking, however, is that while his references contain instances of both the first and second generation of airports in Western Europe, he completely ignores those in Central and Eastern Europe. There is no available data about whether he corresponded with people in this part of the continent, and no information that he ever took a study tour to any of the "little entente" countries. This can be explained by the international political climate in Central Europe in the 1930s and by the tense relations Hungary had with its neighbours at the time. Among the modern airports in the countries surrounding Hungary, the most important one to mention is the building for Prague Ruzyne Airport, constructed at the same time as the one in Budaörs. ${ }^{123}$ Its high technical standard and modern architectural style earned the Czechoslovak airport a special prize at the Exposition Universelle in Paris (1937). Knowing how well-informed Bierbauer was, it is odd that among his European examples, collections and contacts, there is no sign of Prague Airport, even though it was contemporaneous with his own design.

What Bierbauer does point out in his article, however, is that after the conversion of Croydon Airport to civil aviation purposes (1928), the era of the second generation of European airports began. He listed Berlin, Stuttgart, Hamburg and Munich, whose airports were designed to accommodate huge numbers of both passengers and other visitors. Budaörs Airport was built around the same time as major airports were developed in other European cities, including Amsterdam, Birmingham, ${ }^{124}$ Helsinki (Figs. 46, 48), Copenhagen, Cologne, London (Gatwick), Milan, Paris (Le Bourget, Fig. 44), Prague, Stockholm and The Hague (Ypenburg-Ryswyk). The common denominator in the conversions and reconstructions taking place at that time was that in order to increase the number of visitors, which was regarded as a guarantee of financial viability, the work was carried out following models that paid the utmost attention to rationality. Bierbauer's concept, which not only focused on the flow of traffic and on opening up closed architectural elements, but also dealt with how to shape the waiting room and how to create visual transparency, was perfectly in line with international trends, because the design of waiting areas had become a central issue in architectural thinking by the 1930s.

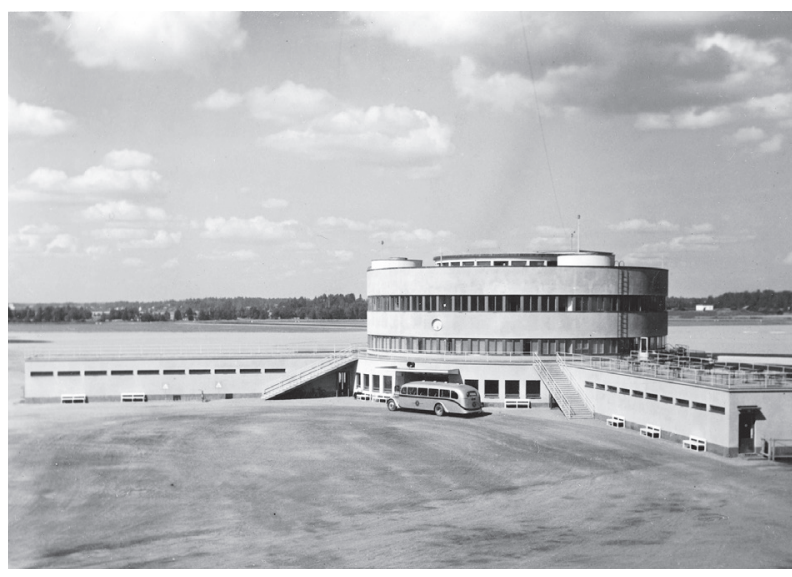

Fig. 48. Helsinki-Malmi Airport, 1936-1938, architects: Vera Rosendahl, Dag Englund (photo: MÉM Borbíró-hagyaték GYN: 659)

Bierbauer made a separate collection of foreign examples of how to deal with this issue, some of which held important lessons. Among the critical examples is Le Bourget in Paris, which was built with several waiting rooms and a large central hall $(240 \times 17.5 \mathrm{~m})$, but which only looked onto the runway from a narrow corridor. The same occurred in Berlin (Tempelhof Neubau, Ernst Sagebiel), even though the dimensions of the floor plan (70 metres in length, with a transverse vestibule, leading to a three-aisled waiting hall, 19 metres high, 70 metres wide and 100 metres deep) would have made it easy to create a more elegant perspective. Bierbauer had other examples of foreign airports that offered no direct view of the runway from the passenger hall, such as Milano Forlanini Airport (1937), Lyon Bron and Amsterdam Schiphol. Bierbauer regarded the use of a right-angled corridor at Hamburg Airport, which interrupted the flow of traffic, as an example of the mistaken adoption in airports of the system used in railway termini, where long passenger halls stood perpendicular to the actual flow of traffic. ${ }^{125}$ Bierbauer preferred the logic of the circle, because when following a circular floor plan, the almost natural organisation that arises along the arc of the circle, clearly recalling the effects of centrifugal force, directs the flow of passenger traffic comfortably and smoothly, while locating offices and desks around the arc leads to a more logical and space-saving arrangement (Figs. 3, 40). Summarising his opinion, he claimed that a design that grouped space together in this way made a proper assessment of and paid proper attention to "the needs of people and life today." 


\section{THE VOLTA CONFERENCE IN FLORENCE, 1936}

Based on my research, preparations for the concept of the cyclorama can be traced back to the Volta conference held in Florence on 25-31 October 1936. The programme for this conference - 'Rapporti dell'architettura con le arti figurative' - concerned the connections with figurative art and the possibilities for cooperation between the arts. The agenda included a debate on art theoretical issues to do with fresco and easel painting, including new technical and social opportunities for the art of fresco. Based on documents in Bierbauer's estate, the Hungarian architect first heard about the Volta conference from his Italian friends at the 13th International Congress on Architecture in Rome in 1935. ${ }^{126}$ After arriving home from Rome, all his attention was tied up with the forthcoming competition for the airport terminal building in Budapest, so he completely forgot about the event. The official invitation he received from the Italian Royal Academy in spring 1936 came as a total surprise. The event was attended by 39 Italian and 24 foreign artists, critics, art historians, architects and museum experts (Fig. 49), including Louis Hautecour, one of the main organisers of the Exposition Universelle in Paris and director of the Musée du Luxemburg, the Dutch architect Willem Marinus Dudok, the Futurist Filippo Tommaso Marinetti and Le Corbusier, regarded as the most respected exponent of modern architecture. The other Hungarian invitee, the art historian Tibor Gerevich (1882-1954), headed the Hungarian Academy in Rome. At the same time, two of the greatest practitioners of mural art, Mario Sironi and Fernand Léger, did

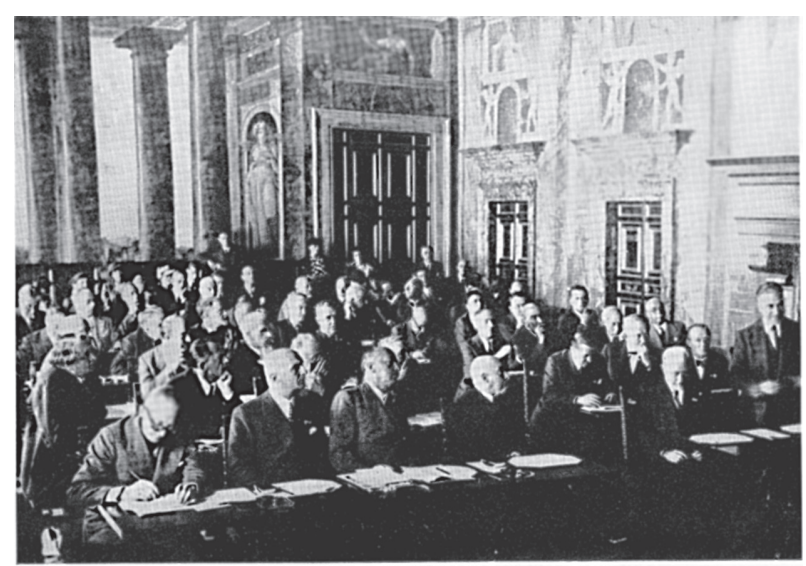

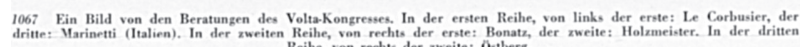

Fig. 49. Participants of the VOLTA conference in Florence, November 1936 (cutting from a periodical: MÉM Bierbauer-hagyaték Borbíró-hagyaték GYN: 659. 11. doboz) not participate. ${ }^{127}$ Marcello Piacentini, the theorist and architect, was originally elected chairman of the gathering, but the debates were moderated by the sculptor Marino Marini. The international political climate of 1936 was dominated by the outbreak of the Spanish Civil War and by Mussolini's campaign in Abyssinia, and this provided a strong political framework to the art conference, which was already characterised by sharp differences of opinion. All the way through, the professional atmosphere at the conference was determined by debates between the two major artistic factions, the rationalists and the traditionalists; one of the main subjects of contention concerned the metaphorical function of murals, and the types of mural that were acceptable in modern architecture. Some participants, including Le Corbusier and Piacentini, felt that of all the branches of the arts, painting was suffering from a severe lack of direction, as could be seen in the gigantic murals unveiled shortly beforehand in the vestibule of the 6th Triennial in Milan, which were compared to pseudo-Byzantine mosaic fragments. Whereas the rationalists regarded such works as clear plagiarism and as idolising bygone ages, the traditionalists who opposed them, led by Ugo Ojetti, declared that painting should revert to its great historical mission. The mood at the conference, as unanimously recorded by a variety of sources, was marked by a spectacular clash of viewpoints. The greatest amount of interest was shown in the dialogue between Le Corbusier and Piacentini. In the latter's opinion, the great antidecorative period of the functionalists was over, and the way forward could be seen in murals and mosaics (Sironi, Gino Severini) decorating the interiors of new Italian public buildings, such as the Sapienza campus of the University of Rome and the Ministry of Justice in Milan. Pagano reminded him that the task of filling empty walls inside buildings was no longer a problem since the arrival of the Futurists. Le Corbusier was not so much concerned with the question of "to decorate or not to decorate" as he was with the use of new mural techniques, as exemplified by works in Italy, Germany and the Soviet Union. He was convinced that it should not happen in line with traditional artistic practices, because while such artists were pretending to respect the architecture, their works were in fact "exploding" the walls. Le Corbusier himself experimented with wall decorations (the Swiss pavilion at the Cité Universitaire in Paris, the "Polychromatic Space," the "Temps Nouveaux" pavilion at the Paris Exposition Universelle), 128 
and he regarded polychromatism as of key importance in the architecture of the future. ${ }^{129}$

The Hungarian reaction to the conference is only known from a couple of contemporary articles. One is a brief interview conducted with Tibor Gerevich, ${ }^{130}$ while the other is an article from 1937 by a certain K. M., titled "Architecture-Sculpture-Painting" ("Építészet-szobrászat-festészet"). ${ }^{131}$ Research has also uncovered a lengthier lecture manuscript by Bierbauer that served as the background material for the latter article. ${ }^{132}$ The lecture was not just a report on the subject of the conference, but also covered the Italian system of state patronage that helped artists as an integral part of Italian cultural policy, and the system of state support for exponents of the new Italian architecture, incepted in 1933. Both systems stated that $2 \%$ of the costs of every new public building should be spent on artistic ornamentation and on decorating the walls. Bierbauer believed that so many examples of monumental art in the new Italian national architecture (e.g. Central Station, Florence, 1932-34 [1935-36], Gio- vanni Michelucci and Italo Gamberini [Fig. 50], and the university campus in Rome) clearly owed their existence to such state programmes. At the same time, he judged functionalist architecture in other European countries to be far more isolated from the fine arts, meaning that the kind of collaboration between painters, sculptors and architects that had emerged in Italy was nowhere near happening elsewhere. An important part of Bierbauer's lecture concerns monumental fresco painting, where he describes the Milan Triennial as an experimental stage in contemporary mural art. In his opinion, true monumental mural painting comes about when the images have a social message. He compared the fresco-like series of pictures by Hans von Marées in the library of the Biological Institute in Naples with the cycle of Saint Ladislaus painted by the Hungarian Vilmos Aba-Novák (1894-1941) in the village of Jászszentandrás, which built on local traditions. In the debate on the role and contemporaneity of easel paintings and frescos, Bierbauer believed that large frescos and the techniques used to produce them were impor-

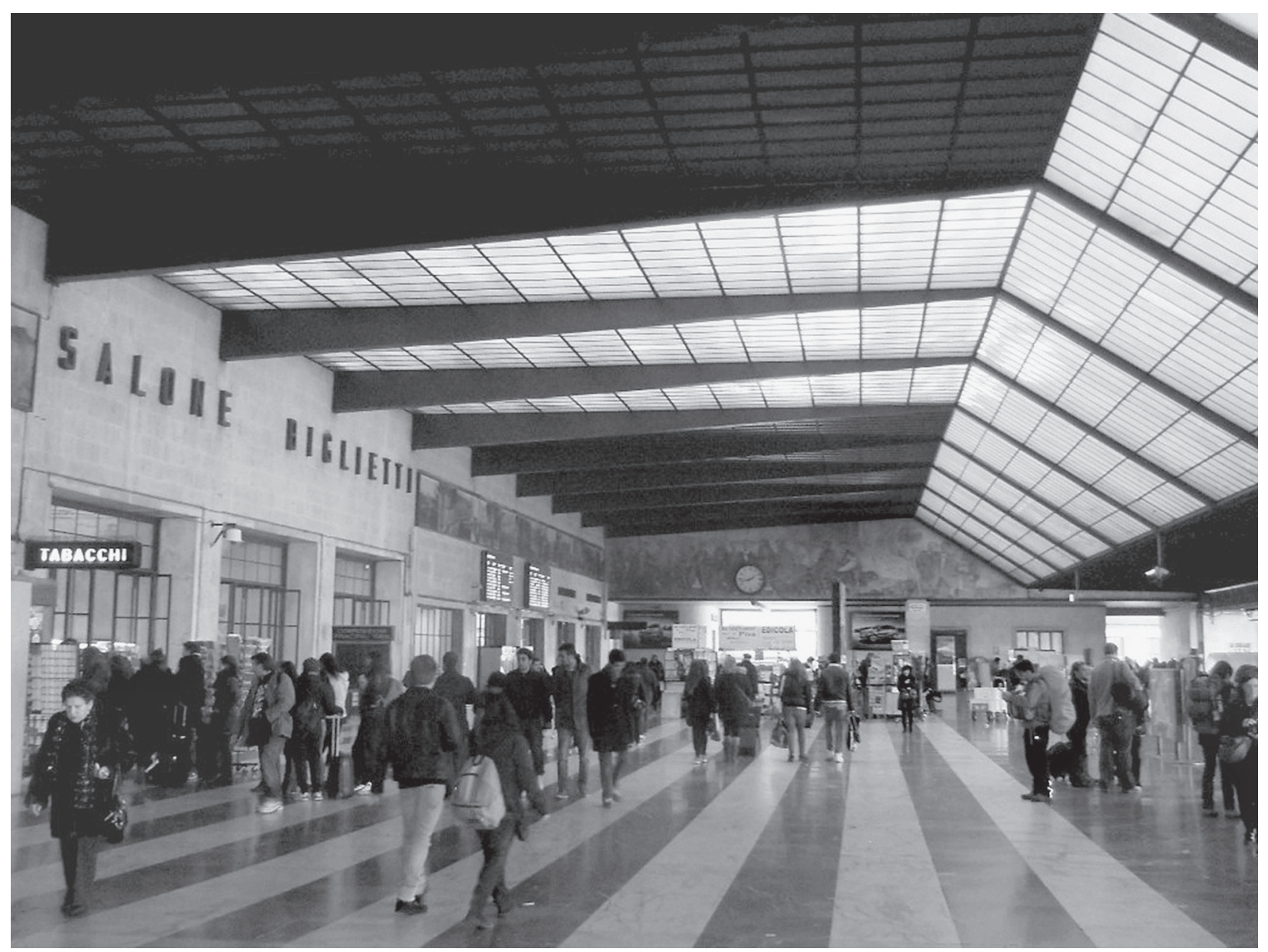

Fig. 50. Photofrieze in the lounge of Florence's Santa Maria Novella railway station, architects: Giovanni Michelucci and Italo Gamberini, 1932-1936 (photo: Pál Ritoók, 2015) 
tant in contemporary art because of their monumental objectives. In this respect, Le Corbusier argued in favour of polychromatism, emphasising the potential of modern materials and techniques for decorating and adding colour to walls, but he did not accord too much significance to monumental fresco painting or sculpture.

The conference also discussed the connection between man and machine, and its part in art and conveying messages. Ojetti fundamentally blamed human vulnerability on the new art, whereas Bierbauer rather saw victims as prisoners of faulty structures. Of all the passionate debates on the topic, which often became personal, the fierce exchange of words between Marinetti and Ojetti drew the most attention, for it concerned the very raison d'être of Futurism. Bierbauer wrote, "Ojetti, in his riposte, called this exhibition a manifestation, an affiche, a poster, which could not be regarded as a serious work of art that would stand the test of time. Marinetti objected to this in the sharpest of tones, opining that a Futurist artist paid little concern to permanence when he could exert an effect today. I have to add that the fascist exhibition, though it has been closed for two years, has not died. It is still living reality, because it fertilised Italian art and Italian architecture. The dynamic impact of the interior shaping and decoration of more than one new Italian building is directly descended from the spirit of this exhibition. It was in vain that certain members of the Convergo said [...] that Marinetti had no right to speak because Futurism was dead. Futurism lives on, if not in his own works, then in the art that came next." The author of the derived article, published in Vállalkozók Lapja, wrote that "...[f]uturist painters found completely new ways of decorating in 'plasticamurale', which often fused painting and sculpture together for the sake of expression, and combined painting with all manner of materials, wood, ceramic, marble and glass, assembled together like mosaic."133

The conference is seen in an interesting light through the notes taken by Bierbauer's wife, who recorded the mood and debates at the conference with, as she put it, "a woman's eyes." Although her detailed reports, based mostly on personal impressions, fall outside the scope of this study, I would nevertheless like to make two exceptions, concerning the speeches made by Le Corbusier and then by Bierbauer. She informs us that her husband did not read out what he had originally planned (in French), but gave an impromptu speech, probably in response to the subjects that had already been discussed. He emphasised the connection that the master fresco painters of past ages had shared with ordinary life and common experience. "These painters saw no shame in painting company signs or crates, but when they were given a greater commission, they did it also with greater dedication. [...] The decay set in during the baroque period, leading to the emergence of painting for its own sake: murals denied the walls they were painted on. [...] If the new architecture is not yet ready to decorate plain walls, the reason for this lies in the fact that painters and sculptors should be expressing something that does not yet actually exist."134 Le Corbusier originally gave his speech the title of "civilisation machiniste," although it touched on the stages in the development of modern architecture and discussed the problems of the way forward. As Mrs Bierbauer wrote, "To give a brief summary, what he more or less said was that since the first manifestations of modern architecture, when it had struggled with problems of concept and structure and deflected resistance, it had now reached a temporary resting point, from where it was safe to look both back and forwards. He referred to the Weissenhof-Siedlung in Stuttgart in 1927, which was one of the key stages in this process. Ten or so more years would be needed before modern architecture could stop being so cold and stiff and become more lyrical and graceful. The structural achievements will allow modern buildings to be as ethereal and poetic as a white butterfly alighting on a green field. [...] For now he rejected fresco painting in modern architecture, saying that bland decorations would only disrupt the wall's unity." 135 Le Corbusier was strict in his rejection not only of fresco painting inside buildings, but also of easel paintings. Following the debates at the conference, he softened his standpoint somewhat, although he still did not accept the decorative role of pictures and continued to reject them in the larger, communal areas of homes. He could at most accept the kind of pictures that provoked thoughtful contemplation, and it was in connection with this that he first used the expression "machine à habiter," adding that the home was a "machine" that served as more than just a place to live. ${ }^{136}$

In the light of the exchange of views that took place at the Volta conference, it can be asserted that the photomontage in Budaörs Airport is an example of the kind of artistic synthesis defined in Florence. This is not contradicted by the fact that the montage was not made using one of the traditional fine art techniques. According to an interview conducted with Bierbauer, the experiences the architect had at the conference helped him to decide on what the interior of the airport should be like. As the interview is such an impor- 
tant source, it is worth quoting from it at length: "Now people like this 44-metre long photomontage, which Mrs Elemér Marsovszky made following my plans. From the very beginning we gave a lot of thought as to how to design the balustrade of the upstairs gallery. Last autumn I was lucky enough to be able to discuss this issue in Rome with Marinetti, the famous Italian artist, who is an active pilot and who has a sense of the aeronautical. Unfortunately Hungarian painters have never had the chance to acquire this feeling, this strange new attitude. Here at home 'aeropittura' is still an unknown term. This is why we chose the photo- frieze, whose artistic function was to provide everyone stepping into the vestibule with a visual experience of flight, and which would be best suited to a circular composition. It might be interesting to mention here in passing that the use of photographic blow-ups for monumental wall decorations is a big fashion now in London, influenced by the Hungarian Moholy-Nagy. After starting work on it, I saw a whole series of similar photofrescos in an English architectural journal! This means we can proudly say that even in this detail, this terminal building is the Hungarian manifestation of the very latest in European architectural thinking!"137

\section{THE CYCLORAMA AND PHOTOMURAL}

\subsection{Mrs Elemér Marsovszky, creator of the cyclorama}

At the start of my research, very little information was available about the creator of the panorama, Mrs Elemér Marsovszky (Ada Ackermann), and although many questions concerning her career have now been clarified, at this point I have still not managed to uncover every aspect of the work of this painter and photographer (Fig. 51). Regarding the early days of her creative career, references to her found in documents from the Borbíró estate are particularly important, because they filled in one of the key gaps in our knowledge of the work leading up to the creation of the cyclorama. Numerous aerial photographs used as working copies have been brought to light, as have four parts of the original photographic maquette, and a series of photographs showing the interior of the Rimamurány-Salgótarján Ironworks pavilion (Figs. 22, 52 ), including images of certain details of the photomontage on display there.

A separate category comprises the montages and dance photos by Ada Ackermann in foreign galleries and museums; such works are not so well-known examples of Hungarian avant-garde art photography at present, but in recent years they have been attracting increasing attention in both Hungarian and international art markets. In 2011, some of her works were exhibited at the Michael Hoppen Gallery in London ("Eyewitness: Hungarian Photography in the Twentieth Century"). These works show that her early montages - similarly to those by foreign artists - were based on motifs pertaining to social injustice (the vulnerability of women, patriarchal rule, mechanised society) or the modern lifestyle (modern transport and fashion, the metropolis). Thanks to recent research into move- ment art, a few of her dance photos have also come to light (Fig. 53). Based on the surviving sources, the largest works in her career that we know of were the photomural for Budaörs Airport, titled "The Experience of Flight" ("A repülés élménye," 1936; Figs. 3, 54, 90, 100), and the enormous photomontage for the Rimamurány-Salgótarján Ironworks pavilion (1939; Figs. $22,52,55-56)$. Both these works were created under the influence of the propaganda art that flourished in

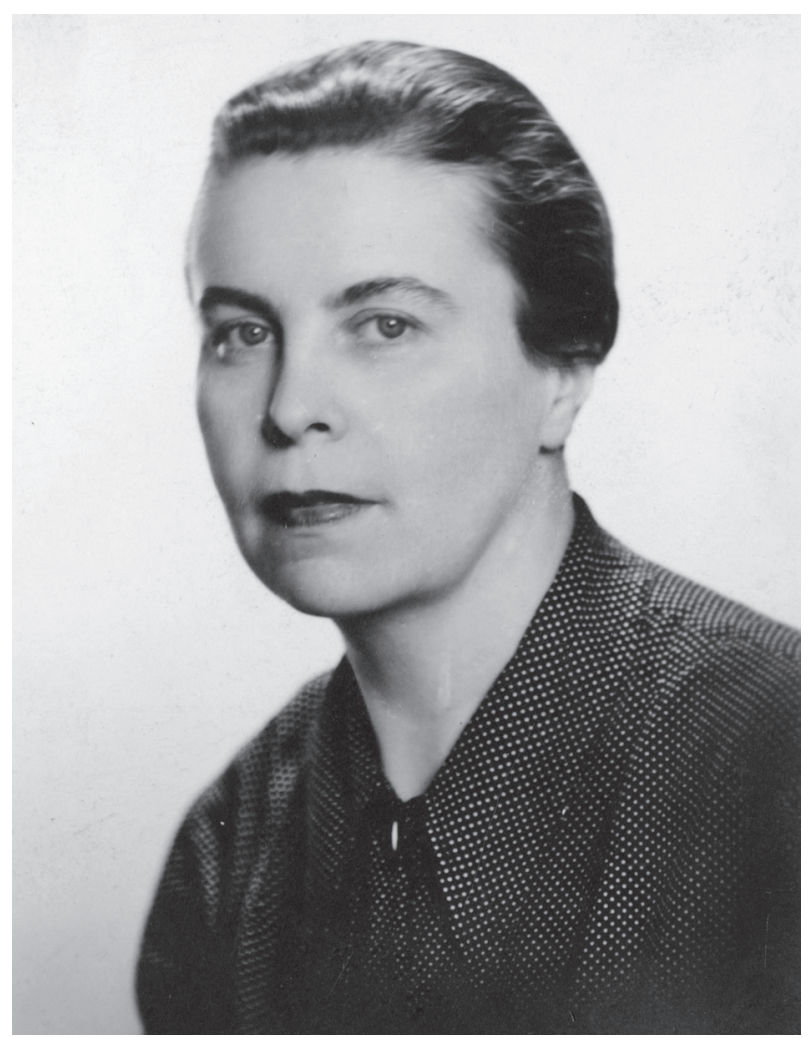

Fig. 51. Mrs Elemér Marsovszky's portrait (photo from the 1930s-1940s: MFM 02480011) 


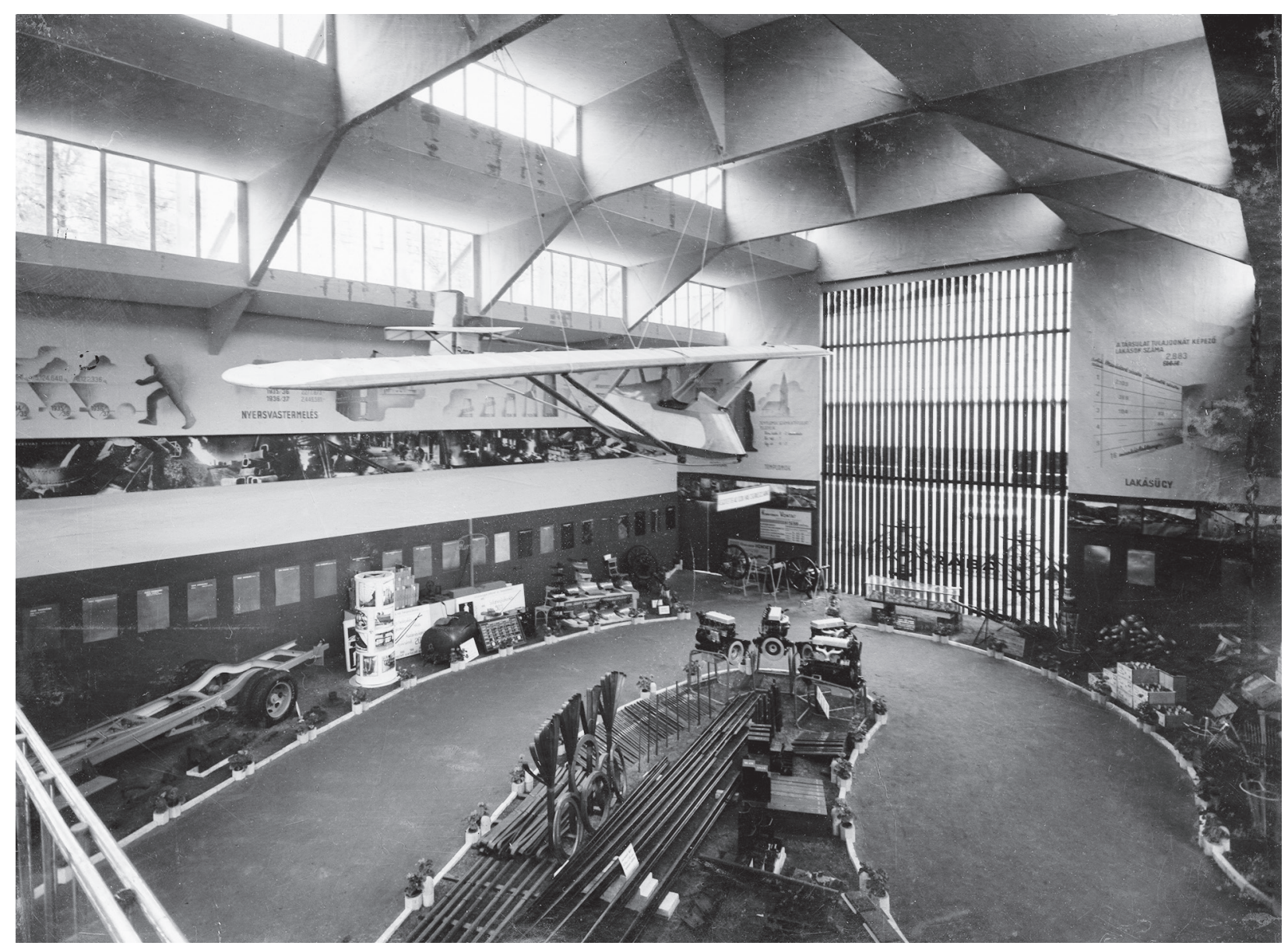

Fig. 52. Interior of the Pavilion of the Rimamurány-Salgótarján Ironworks at the Budapest International Fair, architect: Virgil Bierbauer, 1939; the montage decoration on the wall by Mrs Elemér Marsovszky (photo: MÉM Borbíró-hagyaték GYN: 659. 22. doboz)

the 1930s (Fig. 57). The answer to the question of how the artistic and photographic work of Mrs Marsovszky first came to the attention of Virgil Bierbauer can be found in chapters I and III of the diary kept by his wife, Adrienn Graul, published as Message in a Bottle

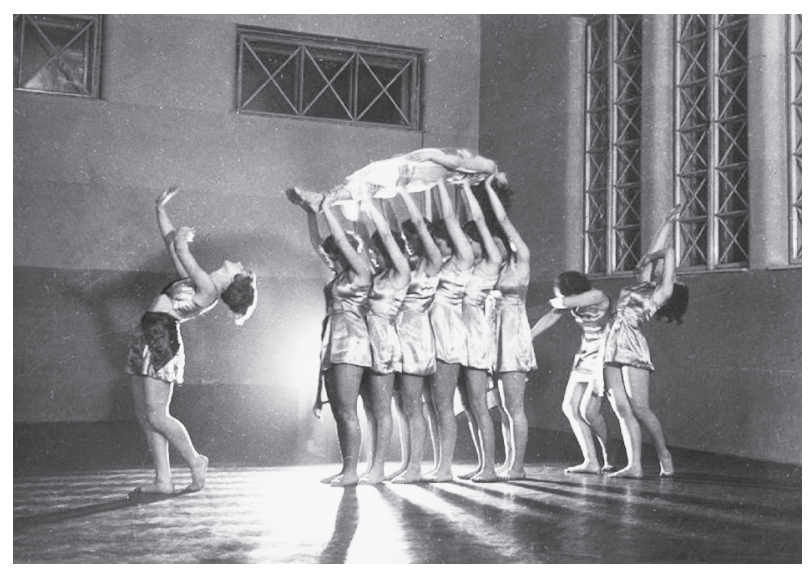

Fig. 53. Modern dance performance, 1930s (photo: Mrs Elemér Marsovszky; BTM Kiscelli Múzeum 2000-234)
("Palackposta"). ${ }^{138}$ Adrienn Graul's diary covers the period from 1915 until 1956, from the time she met her future husband until the end of their life together. It is rather a memoir than a diary in the classical sense, an accumulation of chronologically ordered notes that the author began to type up in autumn 1958 using diaries and records from throughout her life, and which she finally completed in 1966. Mrs Borbíró's original intention, which she actually achieved, was to place Virgil Bierbauer/Borbíró at the focus of the diary, providing posterity with an authentic document of the architect's life's work as seen through the eyes of a woman of culture who had selflessly helped her husband for decades as a translator and secretary. ${ }^{139}$ The diary also shows brief glimpses of her own time at art school and the people she knew there, and gives us insight into the everyday life and spiritual orientation of an intellectual young woman who had just finished her studies (1915-1919) and who was now embarking on her career. Around 1918, when the outcome of the war was looking increasingly grim, Adrienn 


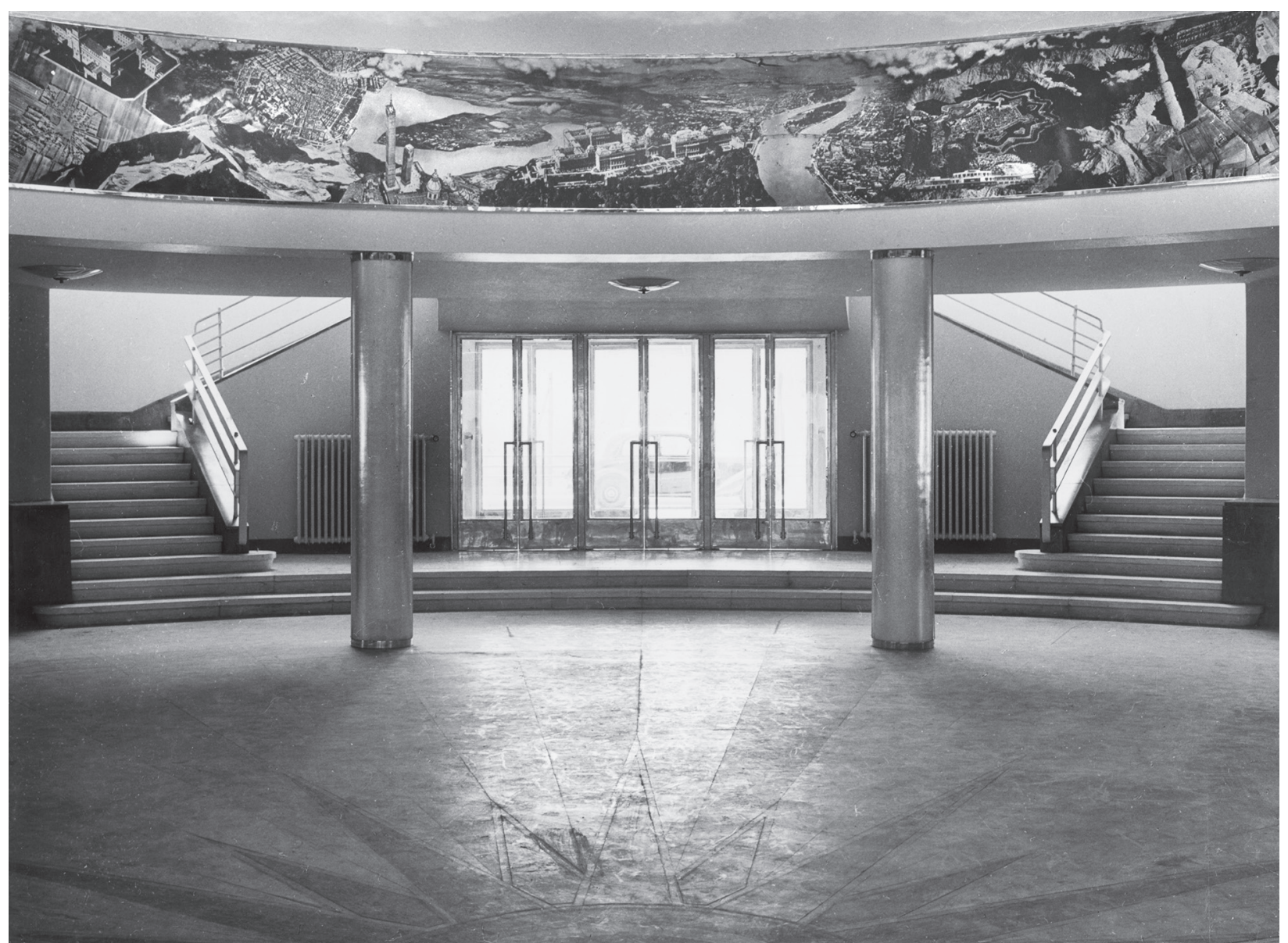

Fig. 54. The waiting room of Budaörs Airport's terminal building with sections VI-VII-VIII of the cyclorama "The Experience of Flight" (photo: Mrs Elemér Marsovszky, Belvárosi Fotómúhely, 1937; MÉM Borbíró-hagyaték GYN: 659. 21. doboz)

Graul decided to keep a diary, about which she wrote, "Perhaps a desire to escape from oppressive reality prompted me to begin writing diary entries at this time (which I kept up for roughly two years), which I have considered burning several times since then, but which now, reading them through anew, I have decided to treat with clemency $[\ldots]$ because $[\ldots]$ they provide a certain picture of two of the most exciting years of those days, and especially because they are very honest."140

The stories she relates from her personal perspective are sometimes extremely biased, but the people and events she describes come to life with the authenticity of an eye-witness account. The diary is also a valuable document of the interwar period in that it sheds light on the spare time activities enjoyed by a young woman from a bourgeois background, just about to embark on her career, and the values by which she judged the world around her. As a result of her education she was an accomplished pianist, she spoke French, she loved the music of Béla Bartók, and she sometimes also attended the modern art movement studio of her sister-in-law, Clarisse Bierbauer. During these early years she participated in the literary studies that were held in the home of the writer and film critic Béla Balázs (1884-1949), but she was voracious in her appetite for everything connected with contemporary culture. In 1918, her final year at college, she earned a scholarship to attend the art colony in Nagybánya (Baia Mare, Romania). Despite the encouragement she received from the leader of the painting school there, István Réti (1872-1945), she eventually gave up the idea of a career in painting; after she had given away her sketches, on 31 October that year she decided to visit her teacher once more in his studio in Budapest, but then the Aster Revolution broke out.

Chapter I of Message in a Bottle records that Virgil Bierbauer and Ada Ackermann - Adrienn Graul's classmate at college - first met in 1916. Twenty years later, this acquaintance would form the basis of the airport commission. While carrying out my research into Ada Ackermann I came upon an unexpected obstacle: there were two women called Mrs Marsovszky in the 


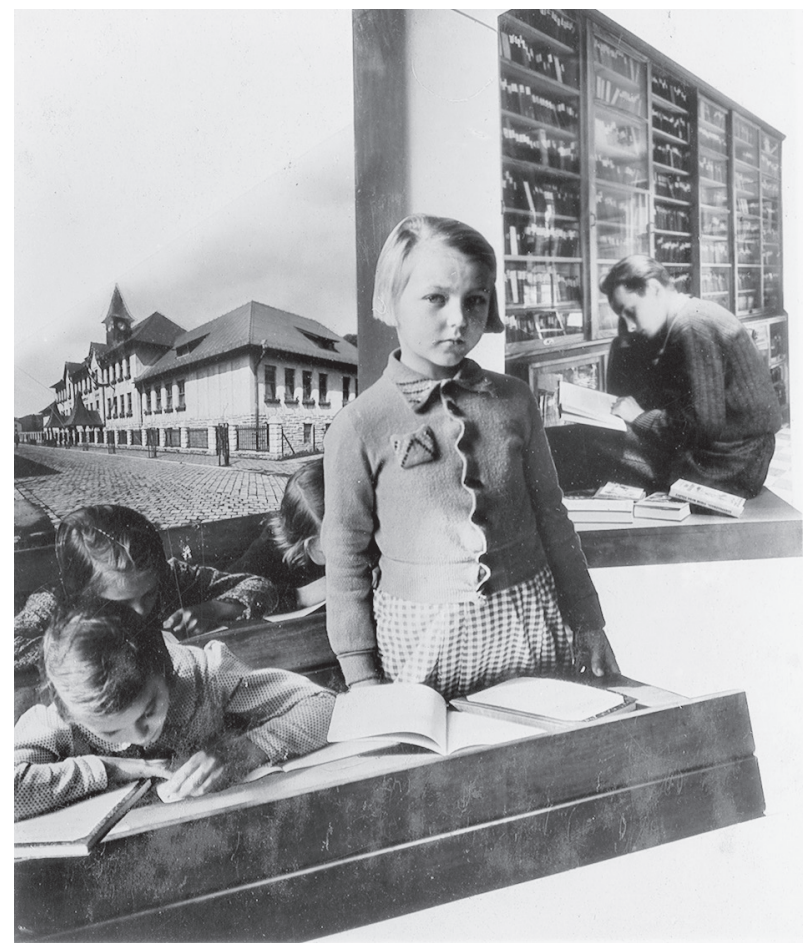

Fig. 55. Preliminary photomontage study for the large photo decoration inside of the Pavilion

of Rimamurány-Salgótarján Ironworks at the Budapest International Fair by Mrs Elemér Marsovszky (MÉM Borbíró-hagyaték GYN: 659. 22. doboz)

interwar period, both from the same generation, and both of whom, as single women, had studied painting at the College of Fine Arts before 1919. Adrienn (Ada) Ackermann was born in the historical county of Torontál on 10 October 1895;141 her father, Márton János Ackermann, was an agent (and later director) of Ericsson Hungary Electrical Company (formerly Deckert \& Homolka). ${ }^{142}$ In 1916 she joined the painting class at the Academy of Fine Arts under Oszkár Glatz (1872-1958). The final record of her studies states that she completed the second semester of the academic year 1918/1919 on 20 March 1919, one day before the outbreak of the communist revolution that led to the short-lived Hungarian Soviet Republic. There is no record of her continuing her studies at the College after $1919,{ }^{143}$ so we now need to turn to her friends for further information. One starting point for this is that in the 1920s Clarisse Bierbauer, Adrienn Graul, Ada Ackermann, Ilona Marsovszky, Ilona Szirmai (1896-1945) and the painter Erzsébet Korb (1899-1925) were all members of the same circle of friends. Details in Message in a Bottle reveal that an interest in literature, music and art played a powerful role in bonding together the new generation who came of age after the turn of the century; in the case of these young female art students, this also involved attending the modern movement art studios.

Before returning to this subject, we need to devote a few words to the college students who would later be related through marriage. It is important to mention Ilona Marsovszky (daughter of Miklós Marsovszky), one of Ada's schoolmates, because her brother, Miklós Marsovszky Jr, married one of Ada's classmates at college, Ilona Szirmai. ${ }^{144}$ Ada Ackermann was also later related to the Marsovszky family, because as a photographer she earned a reputation under the name of "Ada Ackermann (Mrs Elemér Marsovszky)." However, there is still some uncertainty concerning the identity of Elemér Marsovszky - was he Ilona Marsovszky's other brother, or perhaps her cousin? What became of Ada after the Second World War is also shrouded in mystery. ${ }^{145}$ To add to this complex system of acquaintances, the Bierbauers were friends with the architect Pál Müller, who married Ilona Marsovszky.

In the case of Virgil Bierbauer and his wife, we must also mention their relationship with the Bibó family. The two families knew each other by 1920, at the latest, when Virgil Bierbauer married Adrienn Graul, younger sister of Irén Graul, Mrs István Bibó Sr (1889-1979). According to Message in a Bottle, Adrienn often visited Irén and her husband, István Bibó Sr (1877-1935), not only because they were family, but also because she respected her brother-in-law for his invaluable spiritual guidance. The close connection led to Adrienn becoming the godmother of her sister's son, the lawyer and politician István Bibó Jr (1911-1979). Their correspondence was published by his son, the art historian István Bibó III (*1941), who specifically recalled that Mrs Bierbauer was always willing to ask her friends abroad for help on behalf of her godson: "For as long as he lived, István Bibó would often mention Miklós Marsovszky, a friend of the Bierbauers who spent a longer time living in France in the 1930s, from whom one could learn not only about Paris but also about the French culture and lifestyle."146 Miklós Marsovszky's wife, Ilona (Lili) Szirmai, is described at greatest length in chapter III of Message in a Bottle, in connection with a masked ball. ${ }^{147}$ According to the diary, Lili Szirmai had her own studio and painting school in Budapest's $5^{\text {th }}$ District (on the corner of Egyetem Square and Kaplony Street), and in the evenings she attended classes taught by such eminent painters as István Szônyi (1894-1960) and Vilmos Aba-Novák. ${ }^{148}$

Mrs Marsovszky, Ada Ackermann, is first mentioned on the very first page of chapter I of Message 
in a Bottle. This part of the diary brings to life the first encounter between Adrienn Graul and Virgil Bierbauer, who returned injured from the war front in autumn 1916: "I first met him during his recuperation, towards the end of the year, at the home of another member of our circle of friends, Ada Ackermann, where I had already formed a warm friendship with V's sister, Clarisse." "49 Adrienn Graul had already heard about the extremely well-read but slightly eccentric young man, who was studying in Germany, in the company of a friend of hers, Erzsébet Korb; as it turned out later, in 1916 they attended together the literary and philosophical lectures of Béla Balázs, who had returned to Hungary from Berlin. The brief section to do with Ada reads, "Among my friends, Ada Ackermann was also involved in painting at that time (later, as a pupil of József Pécsi, she changed to photography), and she was without a doubt more talented

\section{A NEMZETKÖZI VÁSÁRON A RIMAMURÁNY-SALGÓTARJÁNI VASMÜ RT. PAVILLONJÁBAN}

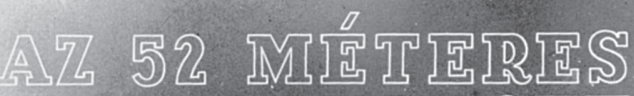
FOTOMIONTAGET KÉSZITETTE: MARSOVSZKY ELEMÉRNÉ ÉSTSA. BELVÁROSI FOTOMÚHELY IV. APPONYI TÉR 1. T: $18 \cdot 62 \cdot 18$

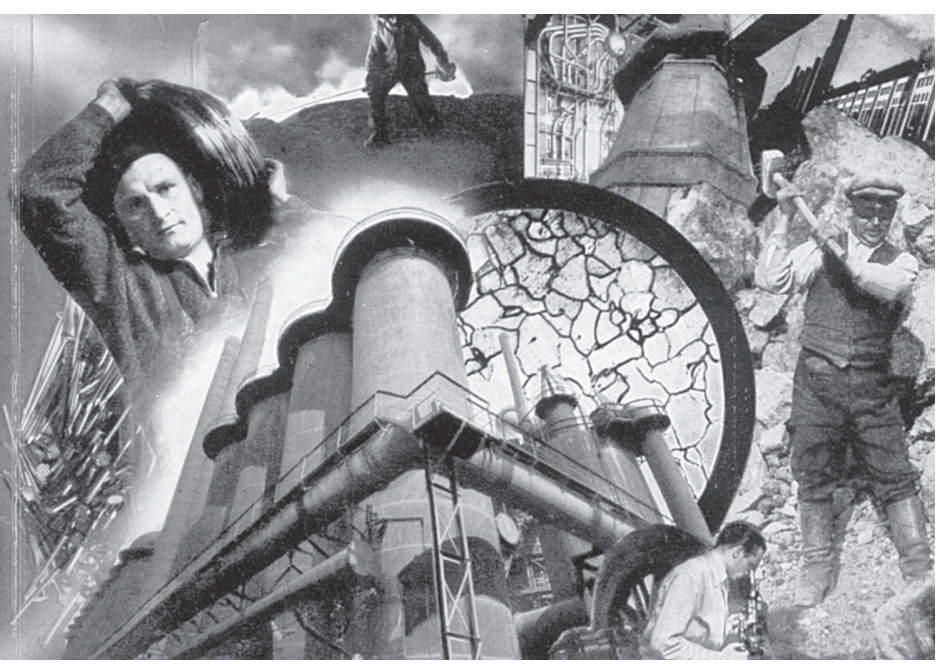

Fig. 56. Advertisement of Mrs Elemér Marsovszky on the 50-meter long photomontage in the Pavilion of RimamurányiSalgótarján Company at Budapest International Fair (MÉM Borbíró-hagyaték GYN: 659. 22. doboz)
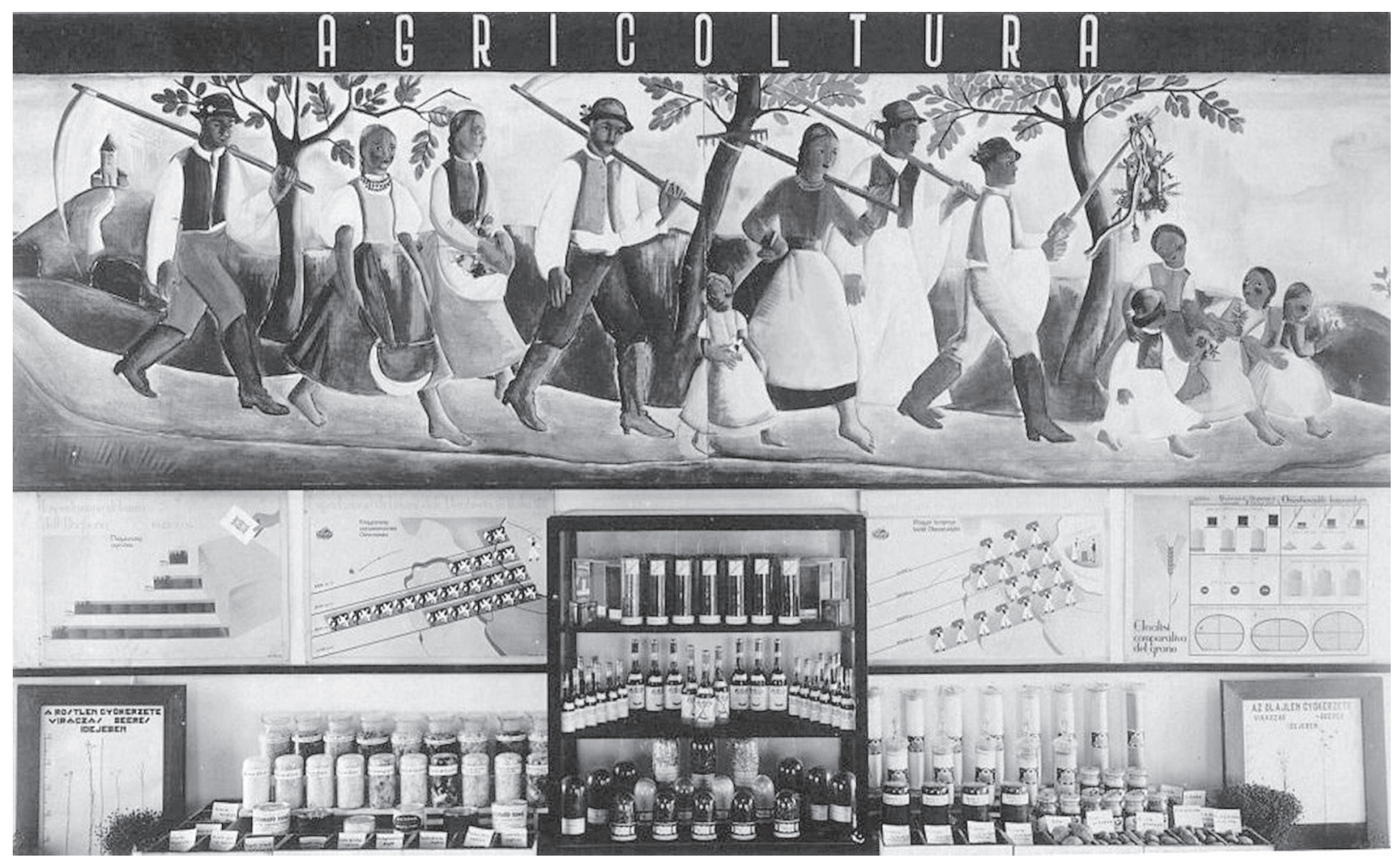

Fig. 57. Display-background, illustrated statistics in order to propagate Hungarian export, Paris, artist: Ilona Marsovszky ("Ili Marsofszky") (IPM FLT 24471-8) 
and mature, but in her thinking she was a little too rational, almost sceptical." 150 It is a fact that when Virgil Bierbauer commissioned her around 1936 to make the panoramic mural, it was not only their personal acquaintance that mattered, but also her familiarity with photography. It is still unclear how much Bierbauer knew about the early montage work Ada had produced, or if he chose her because of the architectural contacts that the by-then reasonably successful photographer had built up.

The next time Mrs Borbíró wrote about her friends from college was when she was working at the Museum of Fine Arts, Budapest, in the Art History Documentation Centre, and gave several drawings to the Hungarian National Gallery: two signed pencil drawings by the sculptor Ferenc Medgyessy (1881-1958), a pencil drawing from 1919 by Adrienn Graul, Lili Szirmai's colour pen-and-ink nude drawing of Viki Derkovits, wife of the painter Gyula Derkovits (1894-1934), and pencil drawings by Rózsi Dabis ("Grünwald's pupil" [Béla Iványi-Grünwald, painter, 1867-1940]) and Adrienne Ackermann ("Glatz's pupil" [Oszkár Glatz, painter, 1872-1958]). She forgot the sixth work. In the gallery's vestibule she presented the folder containing the drawings to the art historian Dénes Pataky (1921-1975), who worked in the Department of Prints and Drawings; a few weeks later she was informed by the head of the department, Anna Oelmacher (19081991), that the artworks had been registered on the inventory. She later regretted the gift, but she had no intention of asking for the works to be returned. ${ }^{151}$ Adrienn Graul never returned to art. We know from the memoirs of her nephew's son, István Bibó III, that she devoted all her attention and energy to assisting her husband's career, and after his death, she spent many long years putting his estate in order, writing Message in a Bottle, and preparing all his material for submission to public collections. ${ }^{152}$

I mentioned earlier that Message in a Bottle writes clearly about the connections between the students at the College of Fine Arts - Adrienn Graul, Erzsébet Korb, Clarisse Bierbauer, Ada Ackermann, and Ilona (Lili) Szirmai - and the schools of movement art. This is not surprising, because the latest research shows that the modern dance schools, where courses were led by Olga Szentpál (1895-1968), Clarisse Bierbauer, Alice Jászi (Mrs József Madzsar; 1877-1935) and others, sooner or later attracted every young person who took an interest in modern art, sociology, science and spirituality, making dance one of the most heterogeneous social segments of the age. ${ }^{153}$ According to László
Beke, who examined the system of relationships in movement art in Hungary between the wars, "With regard to the technical media, in addition to the more traditional genre of reproduced prints, the function of photography also stands out: for many photographers, the photograph was not simply a document but a work of photographic art composed in accordance with its subject (Olga Máté, Dénes Rónai, József Pécsi, László Moholy-Nagy, Kata Kálmán, Angelo, André Kertész, Ergy Landu, Lajos Lengyel and many others)." 154 Ágnes Boreczky, who has examined how the social networks of movement artists extended beyond the avant-garde, has determined that in addition to openness and the emancipation of women and Jews, another substantial virtue of these groups was that they legitimated new professions, such as that of movement teacher or, an increasingly viable career choice for women, photographer. The author also highlights how movement artists acted as mediators between different social groups and how the social status of women began to be evaluated less on their origins and more on the modern careers they chose. ${ }^{155}$

The modern movement art studio of Clarisse Bierbauer is mentioned relatively frequently in Adrienn Graul's diary, but there is nothing in Message in a Bottle to suggest that Ada Ackermann was ever a member of the studio. Nevertheless, she definitely photographed performances by dancers who used modern choreography. A few pictures from 1927 of the movement art school run by Olga Szentpál (Mrs Rabinovszky) ${ }^{156}$ show us what the inside of a dance studio looked like in those days, while they also offer a rare record of the interior design work of Farkas Molnár. ${ }^{157}$ Another point of commonality between movement art and architecture is the fact that dancers also formed a subject of modern photography that was characterised by geometric composition. Furthermore, modern dance studios were expressions of the changes in the modern way of life, which the new architecture was also attempting to bring about in its own field through constructing healthy and rational homes as well as other buildings, such as sanatoriums and cinemas, using its own tools. ${ }^{158}$ Trained photographers and movement artists also embodied the types of highly cultured, middle-class intellectual women after the turn of the century who could exist independently of men, and who in some cases were beginning to carve out their own territory in professions that had hitherto been male domains, such as photography. ${ }^{159}$ A more distant association can be found in the aerobatic displays that were popular in the 1930s, which had to be practised 
with the dedication of a sportsperson, and which can be regarded as a variant of movement art in that they, like dance performances, were built around systems of choreography. At the official opening of Budaörs Airport, a spectacular aerobatic show was performed by a team of Italian pilots, which was photographed more than anything else at the event except for the new building itself. 160

Ada Ackermann is next mentioned in Message in a Bottle in the part of the diary that deals with the preparations for Budaörs Airport, this time by her married name: "The photomontage running around the top of the circular entrance hall, which was designed by $\mathrm{V}$ and made in the City Centre Photo Studio of Mrs Elemér Marsovszky, ingeniously conjured up the sensation of flight and generated a decidedly strong impression on everybody who saw it, as soon as the building was opened to the general public. The irony of fate (or the lack of foresight) meant that the terminal building, just like the whole airport itself, soon proved too small. Then (in 1942) Ferihegy was built, and for want of a better plan, Budaörs was handed over to the soldiers." ${ }^{161}$ The photo series that Mrs Marsovszky made of Budaörs Airport and other works by her that were published in Tér és Forma prove that she was a consummate professional in the field of architectural photography. Her art photography, as already mentioned, is harder to come by, although I am yet to find a satisfactory explanation for this. Between the wars, she signed her name as "Mrs Elemér Marsovszky (Photo by Ada)" or simply as "Mrs Marsovszky," and in the mid-1930s her portrait studio was on the third floor of the KárolyiTrattner building (3 Petôfi Sándor Street, Budapest [4th District]). In 1937 she moved to new premises at 1 Apponyi Square (today Ferenciek Square), which operated as the City Centre Photo Studio, led by Mrs Marsovszky, until $1942^{162}$ (Fig. 58).

The working partnership between Mrs Marsovszky and Bierbauer did not end with the completion of the cyclorama and the opening of Budaörs Airport. The photographer produced the enormous montage for the Rimamurány-Salgótarján Ironworks pavilion at the Budapest International Fair in 1939, while Bierbauer designed the building itself (Figs. 13, 22, 52). The subject was how Hungary was developing socially and economically as a result of the goods produced by the iron industry. In 1938, the following brief report was published about the preparations under way for the Budapest International Fair: "... works are almost completely ready. One example is

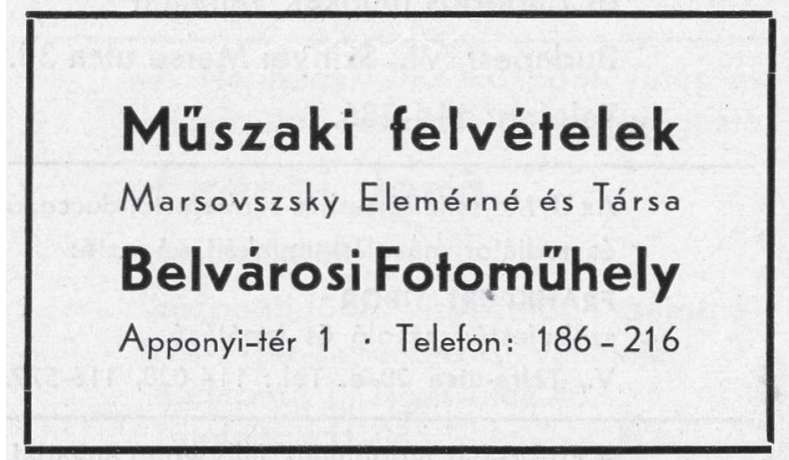

Fig. 58. Advertisement of Mrs Elemér Marsovszky's Belvárosi Fotómúhely

(published in Tér és Forma 14. 1941. 4)

the pavilion for the Rimamurány-Salgótarján Ironworks, designed by Dr Virgil Bierbauer, who has given a new form to the iron frame from last year's building. What an impressive interior! Behind an open pergola is a capacious hall where the exhibits are placed openly and clearly. All of the structures advertising the products of 'Rima'. Tall, polished gridworks made of steel poles or rolled iron girders. The internal pathways are fringed with creative compositions of the crucibles and covers used for casting. Enormous photographs placed high up on the ceiling show images of life in the factories and the welfare institutions. These fine pictures, each measuring ten square metres, are the artistic photomontages of Mrs Elemér Marsovszky. There are palm trees made of iron spheres, covered with shiny tin and zinc plating, Enyedi type sheet iron shingles, ingenious materials and structures everywhere. In five years, annual production at Rima has soared from 28 to 96 million pengós!"163 The montages and photographs showing the Rimamurány-Salgótarján Ironworks pavilion offer further insight into the commercial montage art produced by Mrs Marsovszky. After 1939-1941 Bierbauer no longer had such large design commissions, and he occupied himself mostly with urban planning and with questions to do with types of settlement.

Among the later employees of the increasingly independent Mrs Marsovszky, at the end of the 1990s I had the opportunity to meet one of her pupils, the photographer Erzsébet Beretvás (later Mrs István Harmath) (?-?). The elderly lady could no longer recall many details from the distant past, but one thing she did remember was that the technical expert at the studio, András Budai-Goldberger, played an essential role in producing the enormous blow-ups for the mural in Budaörs Airport and in solving the technical problems that arose. During the work, Mrs Mar- 
sovszky, Budai-Goldberger and Bierbauer together worked out the order and arrangement of the pictures in the photomontage. Erzsébet Beretvás also had recollections of Mrs Marsovszky's elite clientele and of the exceptional quality of the modern portraits made in her studio: "She made beautiful portraits, far more modern pictures than Pécsi." Besides the way in which her models were posed and illuminated, the end result also depended greatly on the surroundings. Ackermann had modern geometric background elements in her studio, and she often photographed her models without any accessories at all. According to her erstwhile pupil military officers and architects were frequent visitors to her studio, and she was also very good friends with the afore-mentioned movement artist Olga Szentpál and her husband, the art historian Máriusz Rabinovszky (1895-1953). This is substantiated with a few photographs that have survived of the dance lessons given by Olga Szentpál. The studio on Apponyi Square, which doubled up as an apartment, had one room that was boarded off from the studio, and her assistants mixed the chemicals in the kitchen. All that Erzsébet Beretvás could remember about Mrs Marsovszky's family was that Ada had a daughter named Jolika, although she knew nothing about what happened to them later in life. Around 1933, in addition to Erzsébet Beretvás, two more apprentices were working in the studio, one of whom was Márta Aczél (1909-1997). Both women belonged to the loose group of photographers who, along with Olga Máté, Ada Ackermann, Juci Laub (1909-1985), Etel Fodor (1905-2005), Kata Kálmán and several others, practised modern photography in the 1920s and 1930s with a high level of training and expertise. Márta Aczél interrupted her university studies in Hungary to study art history and German literature in Frankfurt; after graduating, she returned to Hungary and in 1935 she was introduced by Ivan Hevesi and his wife, Kata Kálmán, to József Pécsi, an exceptional advert and product photographer, who took her on in his private school (in Dorottya Street). According to research carried out by Csilla E. Csorba, Márta Aczél met her future husband, György Kreilsheim (19131945), in 1936; it was through the influence of his friends (Kata Kálmán, 1909-1978; Erzsébet Zinner, 1909-1977) that the young woman turned her attention increasingly towards photography. ${ }^{164}$ In 1997, the periodical Fotómüvészet [literally: "Photographic Art"] conducted an interview with Márta Aczél, in which she briefly recalled her years as an apprentice. "After my apprentice exam I became an assistant to
Mrs Elemér Marsovszky. Her studio was opposite the Franciscan church, and she also earned commissions from industrial companies. She always had an apprentice and an employee: I paid a hundred pengôs in order to be able to work there. When war broke out, the Marsovszkys went to Germany. I worked for her for two years, where I took my magisterial exam in front of Angelo, which was a big deal, because he was one of the star photographers." 165 Two years later, in 1939, the two masters, József Pécsi and Mrs Elemér Marsovszky - and her pupil, Márta Aczél - worked together on an album titled Hungarian Photography ("Magyar fényképezés"). ${ }^{166}$ Mrs Marsovszky's photos not only appeared in Tér és Forma but also in a home design magazine titled A bútor [literally: "Furniture"]. ${ }^{167}$ In 1941, highlighting her skill with composition, she is mentioned in the same line as Rudolf Balogh (1879-1974) in an advert for a colour calendar titled Beautiful Pictures of Hungary ("Szép képek Magyarországról"), featuring a hundred pictures. ${ }^{168}$ The photomontages that can be found at international fairs and in foreign galleries also reflect her talent for taking advertising photographs for commercial and industrial products. ${ }^{169}$ There are a number of other female photographers who worked in this field, whose careers are similarly unresearched; ${ }^{170}$ among them are Márta Aczél ${ }^{171}$ and the excellent portrait and advertising photographer Juci Laub. Mrs Marsovszky's work is not mentioned in any specialist works on the history of Hungarian photography apart from the volume by Csilla E. Csorba titled Hungarian Female Photographers ("Magyar fotográfusnôk"). ${ }^{172}$ The few photomontages made by Mrs Marsovszky that make use of iconic motifs of the modern age, such as racing cars and skyscrapers, which can be seen in Hungarian collections and on the websites of some foreign galleries, reveal her exceptional compositional flair. They are also imbued with the socially critical attitude that is quite characteristic of montage, while in her major architectural commissions she also proved adept with her technical skills. In the field of architectural photography she was a devotee of the progressive style, similarly to the majority of her clients.

To the best of my present knowledge, neither Márta Aczél nor Mrs Marsovszky left behind them as complete a life's œuvre as that of Olga Máté or Kata Kálmán. The points of connection and mutual influences which, via their personal connections, bring the artists closer to our understanding are therefore bound to be of increased value. Today it is still difficult to predict whether it would be possible to put 
together a detailed overview of the career of Mrs Marsovszky that would be as complete as that of, for example, Marianne Brandt, regarded as the best producer of montages at the Bauhaus, ${ }^{173}$ or Hannah Höch, a pioneer of the Dadaist period. Her two large architectural projects are clearly there for us to analyse, but the work she produced in other areas portraits, early montages, dance photography - will require wide-reaching international research. The first work that caught the attention of people abroad was the photomural for Budaörs Airport, and this was followed by her montages and her images of movement art. ${ }^{174}$

However future research into Mrs Marsovszky turns out, investigations into her contemporaries may serve as valuable analogues. A wide range of research is being carried out today into the cultural role of female artists in the fields of photography, film and avant-garde photomontage, including in connection with the world of emancipated women in the modern era. Matthew Biro has described the photomontages Hannah Höch produced during the Weimar Republic as allegories, because in addition to their immediately apparent meaning - recognisable historical figures and subjects -, they also conceal consciously formed secondary meanings, which can only be interpreted within the capitalist power structure, such as the myth of joyous female liberation in Weimar society. In Biro's view, through the rapid development of information technology taking place in the present day, it is the system of symbols of the cyborg that now embodies, in a similar way to photomontage, the mutual influence between manmade technology and consciousness. ${ }^{175}$ The information about Márta Aczél given above was included not only because she was Mrs Marsovszky's pupil. It is significant, in my opinion, that she undertook her studies in Germany in the city of Frankfurt, just like the German-born French photographer Gisèle Freund, who also took a deep interest in photographic theory. She studied under Theodor W. Adorno, Karl Mannheim and Norbert Elias, and after Hitler's ascent to power in 1933 she continued her studies at the Sorbonne in Paris, earning her doctorate in 1936 in sociology and art history, with particular emphasis on the history of photography. During the course of a long career in photography, she worked for Time and Life magazines, was a member of the Magnum Photos, and acquired a reputation as one of the best portrait photographers in the world, which is still valid today. She was personally acquainted with one of the twentieth century's lead- ing writers on photographic theory, Walter Benjamin, whose seminal study, Das Kunstwerk im Zeitalter seiner technischen Reproduzierbarkeit, also was published in 1936. ${ }^{176}$ The fact that both Freund's and Benjamin's studies of photographic theory saw the light of day in the same year indicates that photography had now become a subject of scientific interest. It also signifies the slow process of differentiation that made it increasingly difficult - and pointless - for the generation after the secession (art nouveau) to distinguish between artistic and non-artistic works. In her dissertation ${ }^{177}$ Freund looked at twentieth-century photography from the dual perspective of a practising photographer and a theoretical expert, and she also touched upon the modern-era history of photomontage. The critical observations she wrote about the photomural and photomontage will be relevant from another point of view in connection with the Exposition Universelle in Paris in 1937. ${ }^{178}$

\subsection{Series of architectural photographs about the airport}

Mrs Marsovszky's first large-scale series of photographs was published in a special airport issue of Tér és Forma. ${ }^{179}$ It included the most detailed reproductions of the photomontage titled "The Experience of Flight" (Fig. 59), which can be used to reconstruct the artwork almost completely. ${ }^{180}$ The five-language inscription beneath the pictures is also an important source: "Készítette: Marsovszky Elemérné," "Executé per Mme. De Marsovszky," "Executed by Mrs. Marsovszky," "Studiato della signora di Marsovszky," "Komposition und Ausführung von Frau von Marsovszky."

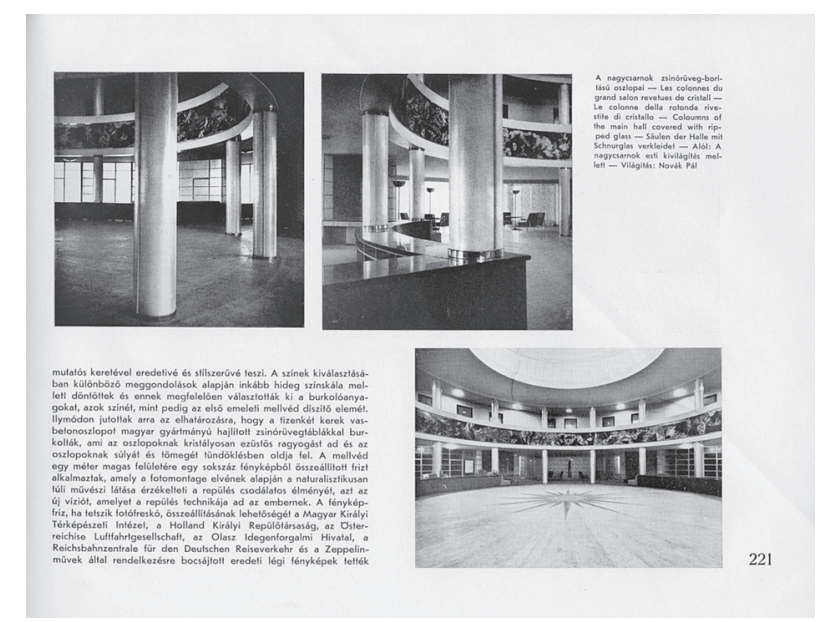

Fig. 59. Page 211 of the special airport issue of Tér és Forma (10. 1937: Budapest 1937) with photos of the photomontage "The Experience of Flight" 


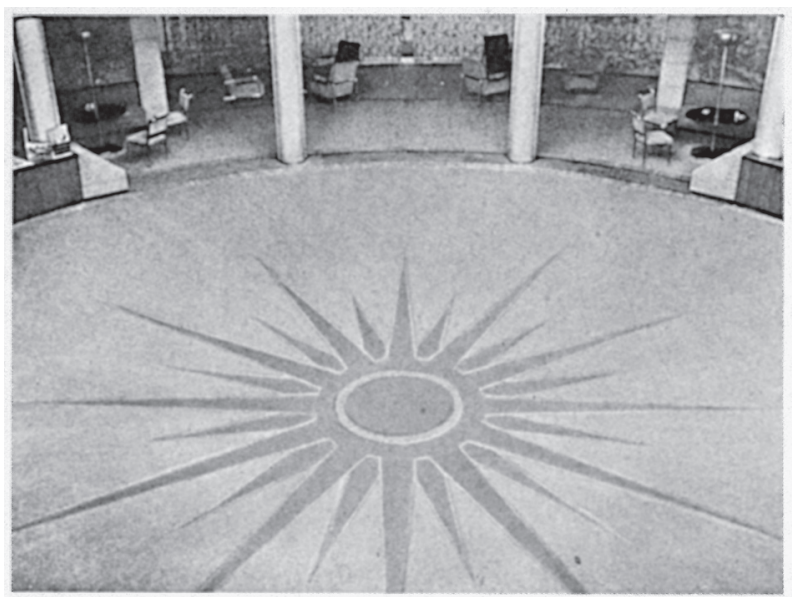

A budapesti repülötér felvételi épületének nagycsarnoka aummiszônyeggel Készítette: $M A G$ Y A R R U G G Y A N A A R U G Y A R

Fig. 60. Advertisement of flooring of the waiting room of Budaörs Airport, published with a colour photograph (published in Tér és Forma 10. 1937. before page 207)

The illustrations in the periodical are worth closer inspection, because after the cyclorama was installed on the balustrade, apart from a few photographs of details, it was only photographed as part of the overall picture in the vestibule. The majority of photographs taken inside the circular hall were made at eye level using a wide-angle lens, apart from one taken from the first floor pointing upwards to show the space with its round skylights. The photographer concentrated all the way through on showing the two spectacular elements of the waiting room - the slender columns, decorated with glass mosaics, supporting the upstairs corridor, and the enormous cyclorama - from a variety of perspectives. According to eyewitness accounts, the light reflecting off the glass elements covering the columns gave the entire waiting room an airy sheen that was unlike anything else they had ever seen.

The photos of the interior also clearly show that the floor level of the waiting room had been lowered by three steps so as to ensure a unified visual effect. The reason for this was to align the horizon of the runway even more perfectly with the eye level of people as they entered the terminal building, to enhance the impact of the panorama outside. The special issue of Tér és Forma also included a separate chapter written by Bierbauer about the photofresco, briefly summarising its concept and technique. ${ }^{181}$ It should be noted that the most daring photographic compositions of the outside (the control tower, see Fig. 38; details of the terraces) were attached to this section.
The report in Térés Forma still offers the most complete overview of the airport, and articles on the airport in foreign publications took most of the pictures from this source. The original negatives have not survived, but there is a set of original prints, ${ }^{182}$ which were used for the publications and architectural photo exhibitions presenting Budaörs Airport between 1999 and 2011. 183 Only one contemporary colour photograph of the airport is known: a $9 \times 6 \mathrm{~cm}$ colour advert showing the rubber flooring in the waiting room. ${ }^{184}$ The photo shows the waiting room floor as seen from the balustrade, clearly revealing the shape of the floor covering, with its sunray motif, and its orangey-yellow tones. It also proves how harmoniously the cool, restrained colour scheme had been put together (Fig. 60).

Apart from Mrs Marsovszky, Zoltán Seidner took most of the architectural photos of the terminal building. We also found another excellent series of photographs, taken between 1945 and 1948 by Béla Hollenzer, a specialist in technical and industrial photography. ${ }^{185}$

\subsection{A few aspects of the development of montage in Hungary}

The initial use of the montage principles date back to the time of modern art movements. It first appeared as a new form of expression in the art of the Dadaists and Futurists, who assembled together worlds of fantastical and improbable imagery out of components that were in themselves realistic. The first major exponents of the genre and technique of montage, John Heartfield, Georg Grosz, Hannah Höch and Raoul Hausmann, cut details out of photographs and placed them in totally different contexts. Similarly to Russian avant-garde artists, the Dadaists of Berlin also used photomontage for political propaganda, and often focused on a central idea (war, exploitation, the complexity of city life) or motif (metropolises, politicians, commodities). The history of montage was first summarised by Raoul Hausmann after a photomontage exhibition held in Berlin in 1931. ${ }^{186}$ Among Hungarian avant-garde artists, Lajos Kassák (1887-1967) also discovered the genres of photomontage and collage, 187 and following his lead, Ferenc Haár and Lajos Lengyel began to produce montages with political themes. ${ }^{188}$ Kassák, as a typographer, designed countless book covers, posters and advertisements using these techniques, ${ }^{189}$ and in 1967 he produced a late self-portrait by reworking a photomontage he had made back in 
1923. ${ }^{190}$ The contradictory reception of the genre in Hungary is illustrated by the fact that whereas articles on photomontage were not only published in Kassák's avant-garde periodicals but also, after 1929, in more mainstream magazines such as Magyar Grafika, Magyar Müvészet and Magyar Iparmüvészet [literally, respectively: "Hungarian Prints and Drawings," "Hungarian Art" and "Hungarian Applied Art"], the Hungarian photographic specialist press, apart from a few exceptions, published very little information about the Bauhaus or László Moholy-Nagy. ${ }^{191}$ Many of Moholy-Nagy's fundamental works - "Malerei Photographie Film,"192 "Vom Material zu Architektur,"193 "Vision in Motion"194 - were unavailable in Hungarian for a long time, although some of his theoretical writings did appear in Hungarian periodicals, such as Korunk, Telehor, MA, MUNKA, and Perspektivva. ${ }^{195}$ One important exponent of contemporary photography criticism, Kálmán Brogyányi (1905-1978), a writer on photography who lived in Bratislava, was influenced by Moholy-Nagy both in his writings and in his general attitude. He published the first instalment of his multi-part study on photographic theory in 1932 in the columns of Forum, an art and architecture periodical, which was published separately in 1933 as "The Art of Light" ("A fény mûvészete"). ${ }^{196}$ According to Brogyányi, apart from the influences of Futurism, Expressionism, Cubism and Surrealism, art photography became truly independent with the triumphs of abstract photography, including montage and the photogram. He regarded photomontage as the pinnacle of mass culture after the First World War, and he ends his book with a definition of the genre: "Actions or events taking place in many different times and places simultaneously convey their messages within the time and space of a single composition."197 The significance of his work on photographic theory can be measured against the incredible passivity towards the achievements of modern art photography shown by the photographic press in Hungary (Fotómüvészeti Hirrek, Magyar Fotográfia and Fényképészeti Lapok [literally, respectively: "Photographic Art News", "Hungarian Photography" and "Photographic Pages"]). ${ }^{198}$ The publication of two landmark books - MoholyNagy's Malerei Fotografie Film (1925) and Brassai's Paris de Nuit (1932) - was more or less ignored in Hungary, as was the "Film und Foto" exhibition that opened in Stuttgart in May 1929, even though it featured the very best of modern photography of the 1920s. However, two albums of photography - Albert Renger-Patzsch's Die Welt ist schön (Munich, 1928) and Helmar Lerski's Köpfe des Alltags (Berlin, 1931) were well received in Hungary, and were reviewed by the poet Dezsô Kosztolányi and the architect Farkas Molnár. ${ }^{199}$

Photomontage as a creative genre undoubtedly made its breakthrough at the "Film und Foto" exhibition at the Deutsche Werkbund in 1929, ${ }^{200}$ where montages had a separate section all to themselves, alongside the categories of portraits, nature photography, aerial photography, scientific photography, photograms and advertising photography. The new style was represented by the Dadaists Grosz, Heartfield and Höch, but also Moholy-Nagy and El Lissitzky, whose Self-Portrait: The Constructor (1924), one of the most iconic works of montage ever produced, was also on display.

One year after the exhibition in the Deutsche Werkbund, in spring 1930 an exhibition of the latest achievements in advertising art was held at the Museum of Applied Arts, Budapest, organised by the Hungarian Association of Book and Advertising Artists $^{201}$ (Figs. 61-62). By this time, the commercial value of the photomontage and the typophoto was widely recognised, although opinion was split concerning the development and artistic worth of the genre. Some still equated montage with an accumulation of images that led to unique visual confusion. The photographic press tended to be none the kinder about montages, mostly dismissing them as compositional distortions of imagery, decrying their lack of "originality," and ultimately rejecting the genre as a method of artistic expression. The works on display at the exhibition, however, received positive reviews, with the press heaping particular praise on the artistry of Albert Kner, Farkas Molnár, Sándor Bortnyik and László Moholy-Nagy, as well as mentioning certain young artists by name: Lajos Lengyel, a pupil of Lajos Kassák, György Kepes (1906-2002), who studied under Kner, and József Pécsi's protégées, Zsuzsi Pintér, Éva Besnyổ and Panni Budai. ${ }^{202}$ The exhibition also featured a commercial prospectus made using the photomontage technique by György Radó, who would later compose the outstanding photomontage summary of Hungarian modern architecture for Virgil Bierbauer for the Milan Triennial in 1933 (Fig. 21). Lajos Kassák wrote about his experiences in the exhibition catalogue (1930): "In every work of art, the artist wants to manifest some inner emotion, some unlived experience or suppressed desire, or a thought that cannot be realised in everyday life, and to express it in colour, sound or shape. [...] The photographs 


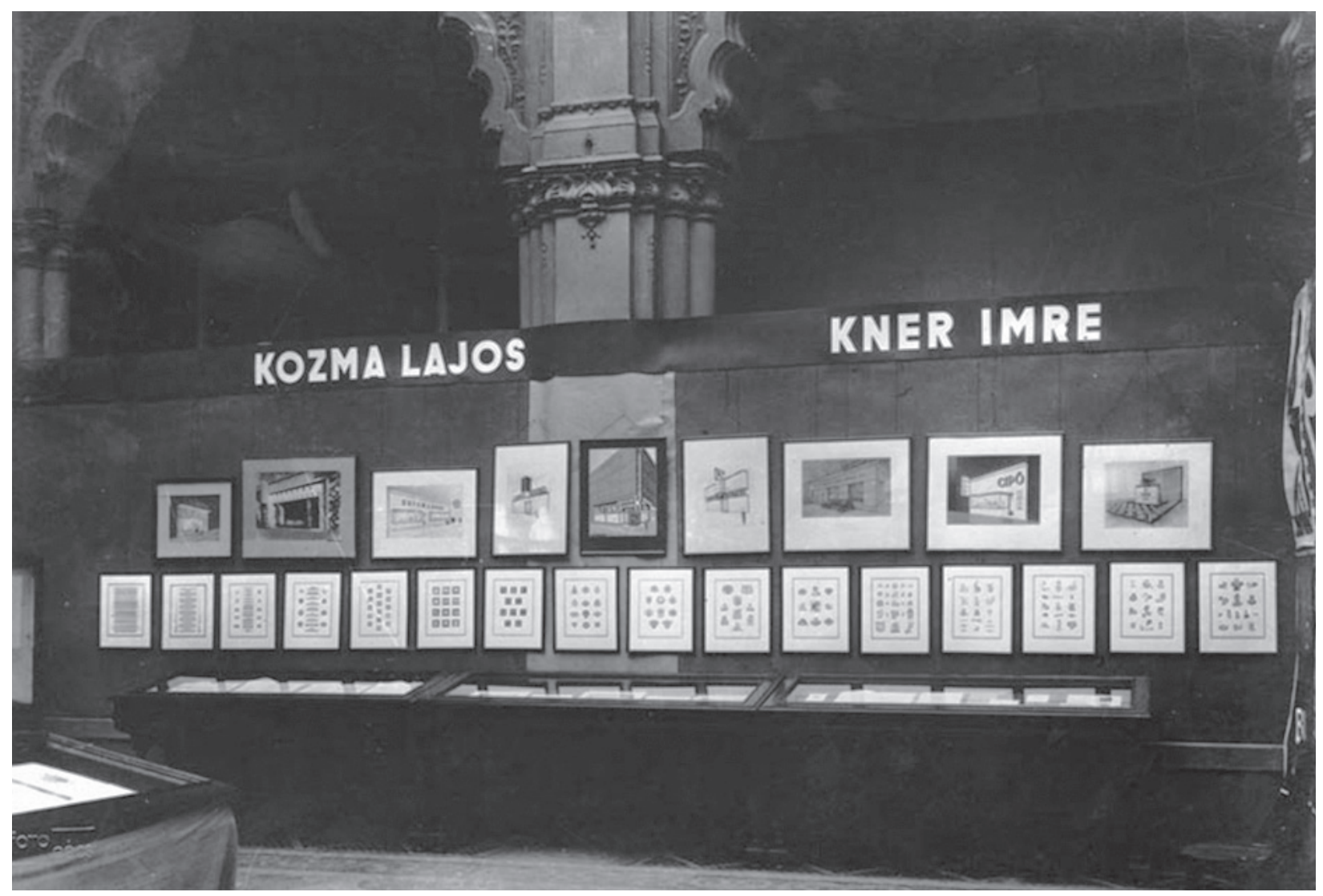

Fig. 61. Exhibition of the Hungarian Association of Book and Advertising Artists at the Museum of Applied Arts, Budapest, 1930 (photo: Éva Besnyô; IPM FLT 24550-2)

laid out in front of the montage artist are also mere materials. [...] It is self-evident that a good photomontage can only be made by someone who understands the special nature of the material, and who, by virtue of his human traits, has the skill to conquer this material, to shape it, to bring expressive harmony to the values of the work. [...] The majority of monteurs are not aware of the character of their material, and consequently their finished works are very often little more than senseless games or colourful but ineffectual sets of phrases. Both these outcomes are the opposite of the original objective of photomontage. As it developed, montage never renounced its purposefulness and its emphasis on intellectual tendencies illustrated with intellectual motifs." ${ }^{203}$ Kassák drew a sharp line between painters and montage artists in terms of their way of thinking; he asserted that makers of applied montages should concentrate less on abstraction and more on the nature of the colour, shape and message in the material they wished to process. Imre Révész (Fig. 63), in the reply he wrote for the columns of Magyar Fotográfia, did not dispute that photography had become the dominant force in graphic design. ${ }^{204}$ At the same time, however, he believed that montages

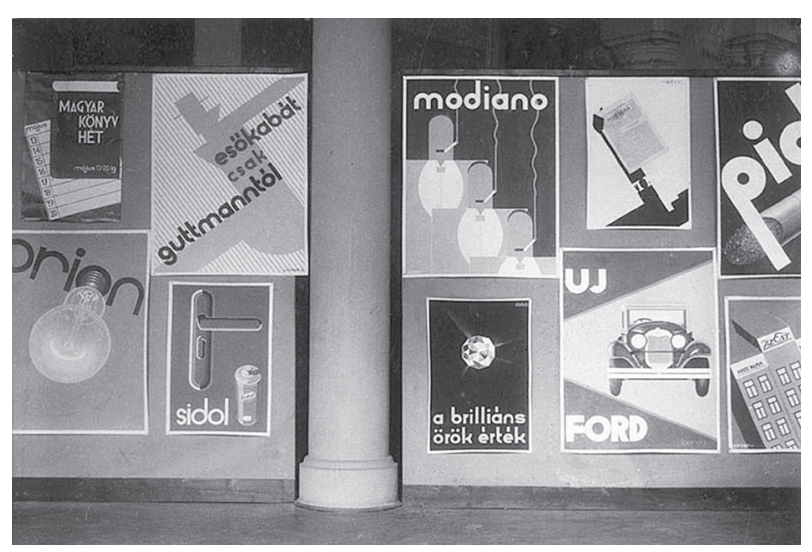

Fig. 62. Exhibition of the Hungarian Association of Book and Advertising Artists at the Museum of Applied Arts, Budapest, 1930 (photo: József Pécsi; IPM FLT 24550-7)

produced primarily from newspaper cuttings suffered from the fact that its method of pictorial structuring was based on cutting out photos intended for other purposes. In Révész's view, this was not autonomous photographic creativity; moreover, as he considered the pictorial elements making up montages to be of uneven artistic worth, it was only rarely that a work of art produced in this genre could be truly convincing. 

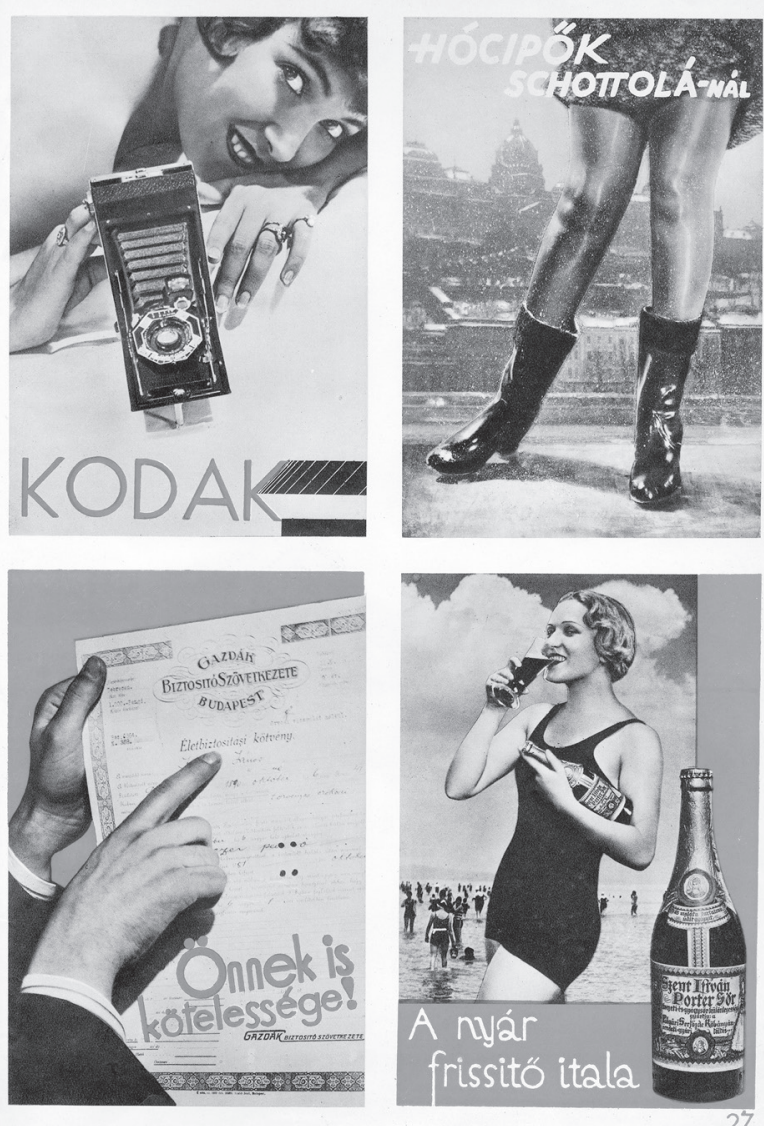

Fig. 63. Advertising pictures by Imre Révész, 1920s-1930s (published in RÉVÉSZ-BIRó 1931. 37.)

Reacting to the exhibition of advertising art and the questions that it raised, a remarkably large number of contributors to Magyar Grafika magazine in 1930 wrote about photography. Among them was Sándor Bortnyik, who underlined the importance of the press in conveying new photographs, whose ordinary subject matter and style (new details from new angles) were the main factors behind the unusual impact they could exert on viewers. Besides the influences of motion pictures and colour photography, he also linked the development of new art photography with contemporary architecture, because of its effect on modern life. ${ }^{205}$ Both in typography and in structure, the trinity of economy, simplicity and practicality, which permeated artistic and technical thinking and could be traced back to the principle of functionality, was a unique manifestation of the link between modern architecture and graphic art for advertising (Fig. 64).

Many techniques for producing photomontages were developed between the wars, and as we have seen, the term "montage" was used to refer to

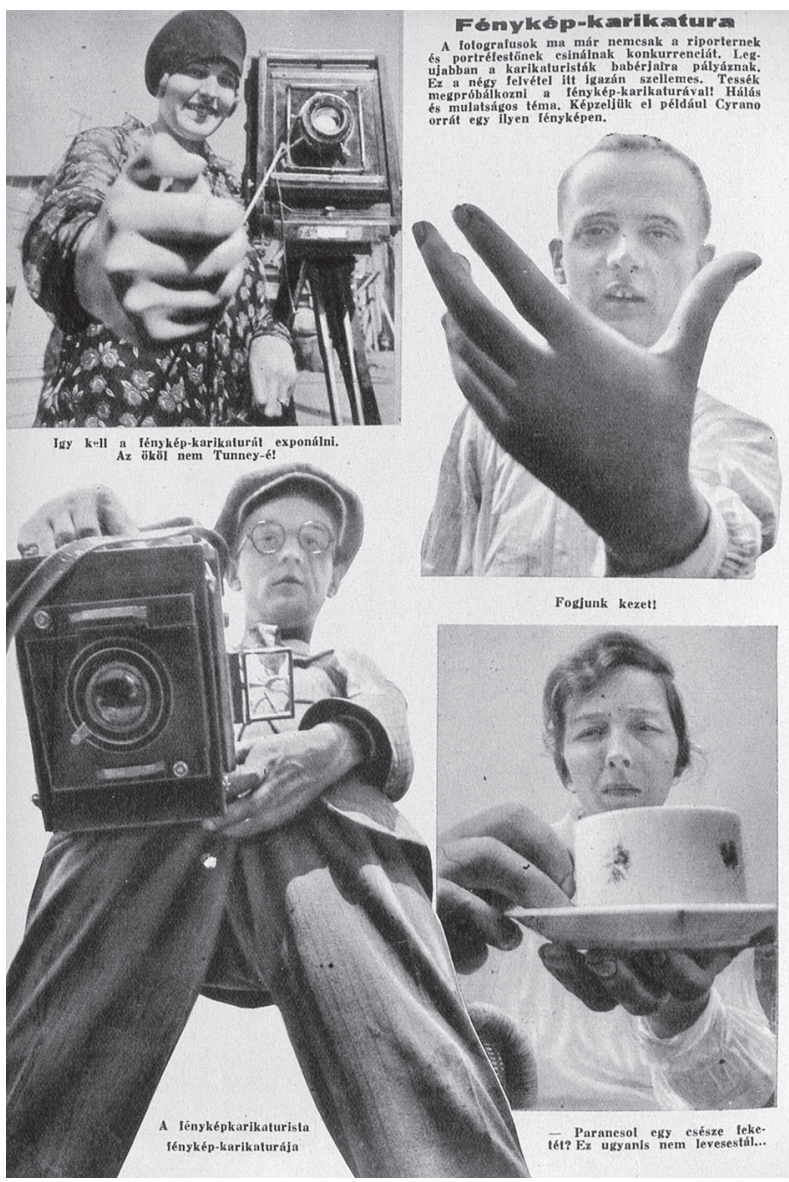

Fig. 64. Photo cartoon of Márton Munkácsy from Szinházi Élet ("Theatrical Life") magazine, 1920s-1930s

the montage images that appeared in the press, to enormous exhibition installations made out of photographs, and to photomurals functioning like fresco paintings. Contemporary foreign specialist publications, from the Bratislava magazine Fotograficky obzor to Photographic Amusements, featured detailed descriptions of how such works were made. ${ }^{206}$ The only Hungarian article to do the same (that we know of) was an edition of the periodical Tükör [literally: "Mirror"], which published a description of the Budaörs "photofresco" (as they called it, although technically it is a photomontage). ${ }^{207}$ According to a report in Magyar Grafika, photomontages were made either by cutting or by copying. Cutting involved, obviously enough, cutting out details from pictures and sticking them in a rearranged form onto cardboard; where necessary, the joins were evened out using paint, and finally the prints were retouched to make them perfect. In the case of copying, the success of the procedure was decided in the photographic laboratory, and this required greater experience. Among the specialist photographic magazines, in 1934-35 Fotóélet [literally: 
"Photo Life"] published an extensive article on possible ways of making photomontages for amateur photographers with no experience in the technique. The author, Ervin Schulz, also regarded montages made with several negatives as the most difficult method. ${ }^{208}$ The spread of montage techniques also contributed to the debate on copyright in the case of artworks that made secondary use of someone else's material. In general, the authors of compositions consisting of images from other sources completely ignored the question of who owned the original pictures. Some recommended following the example of Bortnyik, Molnár and Moholy-Nagy: namely, after drafting the composition of the photomontage, the artists themselves should then go and take the necessary photographs. Among the works he submitted to the exhibition of advertising art, Farkas Molnár also presented a constructivist-style plan which he later filled in with details of photographs he took in his own apartment on Delej Street in Budapest. Molnár took these photos when his home was briefly opened to the public as an example of the minimalist apartments that he wished to promote. A different question is addressed in the following passage: "And why do some people still insist on calling this photomontage? Because this is how the style of using photography developed in graphic design and typography. When they utter this word, everybody knows what they mean. When they pick up a work that is combined with a photograph (tram poster, book cover, advertising flyer, printout), it is always the work of one hand, of a single artist"209 (Fig. 65). Nonetheless, some of the artists at the exhibition of advertising art credited the name of the photographer they collaborated with, including

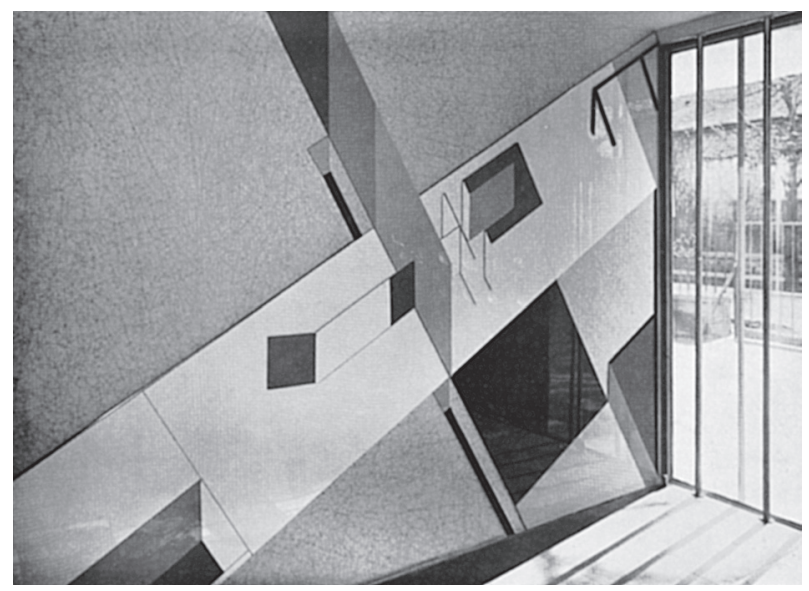

Fig. 65. Pasaréti Street, 2nd district, Budapest, wall decoration based on the 1922 constructivist composition of Farkas Molnár, 1936; wallpaper under colored glass (photo published in Tér és Forma 9. 1936)
Albert Kner: "Albert Kner. Book cover. Photomontage. Photo: Landau, Paris,"210 "Tram poster by Albert Kner. (Photo: Bortnyik)."211

At the exhibition, László Moholy-Nagy, home on a visit from Germany, exhibited just a few designs for book covers. Nevertheless, the mere presence of his works here was something of a landmark, for this was the man responsible for the theory behind linking images with texts (typophoto) and with drawings (photoplastics).212 "Photography is highly effective when used as typographical material. It may appear as illustration beside the words, or in the form of 'phototext' in place of words, as a precise form of representation so objective as to permit of no individual interpretation. The form, the rendering is constructed out of the optical and associative relationships: into a visual, associative, conceptual, synthetic continuity: into the typophoto as an unambiguous rendering in an optically valid form. [...] In the future every printing press will possess its own block-making plant and it can be confidently stated that the future of typographic methods lies with the photo-mechanical processes."213 By around 1930, certain graphic designers in Hungary had also come to the conclusion that phototypography and photomontage would play an increasingly important role in the future of typography, including printing. ${ }^{214}$ However, as we have already indicated, photography was not incorporated into modern Hungarian typography overnight, nor was the adoption smooth. 1929 also saw the publication of Foto-Auge, 76 Fotos der Zeit, 215 regarded as the encyclopaedia of modern photography. One of the first to review it was Farkas Molnár, whose comments on the section dealing with photomontage read, "The unique charm in the realistic photographs published in the book derives from the novelty of the subjects. Some of them are even certain to catch the eye of the lay observer. An X-ray of a bouquet of flowers. Wonderful pictures of the miracles of modern industry [...] the airplane photographs in particular provide spectacles that are more than interesting." ${ }^{16}$ The Bauhaus also experimented with photomontage, borrowing the technique from the Futurists and Dadaists. The montage titled Metropolis/City, by Paul Citroën, which appeared on the cover of Berliner Illustrierte, was mentioned by Farkas Molnár as an example of the first truly powerful montages. In a later, revised edition of his article, he explains the sudden spread and popularity of photomontage in the advertising industry with the increased demand for cheaply produced advertising materials, which led to the mass appearance of works 
of montage that were of poor quality and misunderstood. As he wrote, "The photomontage is a universal means of expression, a flexible and objective look that is suitable for all kinds of purposes, as long as one knows how to handle it." 217 The technique of photomontage was also widespread among architects, who used montage mostly to create visualisations, as well as advertising and propagandistic materials. József Pécsi, the art photographer, also experimented with the technique, so it is interesting to compare how the two professions fared in their efforts. Pécsi, who was virtually unrivalled in the field of advertising photography, regarded photography as a useful device in the modern advertising industry because of its objectivity and its adaptability. In his opinion, pictures made with the montage technique were unsuited in the commercial sphere, which strove to present authentic images of the products being advertised; consequently, in 1930 he recommended that montage be restricted to book covers and title pages: "Only for the sake of completeness do we make mention here of the products, latterly known by the name of 'photomontage', that also result from the mutually inspiring relationship between the photo studio and the printing works. They are often interesting, sometimes even compelling, and seem to be suitable more for title pages than for advertising purposes, because the conscious mix of multiple heterogeneous elements is barely compatible with the commercial, propaganda objective to present the given objects attractively but realistically in order to exalt them." 218 Pécsi, as one of the most outstanding advertising photographers of his day, wrote these lines a year after the publication of Photo und Publizität - Photo and Advertising, ${ }^{219}$ which brought him wider international recognition. Pécsi's advertising images, executed in the style of Neue Sachlichkeit, stood as examples for his contemporaries to follow, as did the seminal volume, Photo-Advertising (Photo-reklám), jointly written by Imre Révész and Irma Biró, which was published in 1931.220

Taken all together, contemporary writings and critical reviews force us to the conclusion that advertising artists in Hungary took a keener interest in the issue of applied photography than most photographers, who were either left completely cold by the technique of photomontage, or whose achievements in the area were unremarkable. Perhaps it is no exaggeration to state that montage was more widely used in the fine arts and in certain applied genres (advertising, publishing) than in art photography (Figs. 66-67). This situation was compounded by the critics, who saw no true artistic value in the genre. It is illuminating to quote the thoughts of the art historian István Genthon on this topic. In 1925, he considered photoplastics made by cutting things up and pasting them

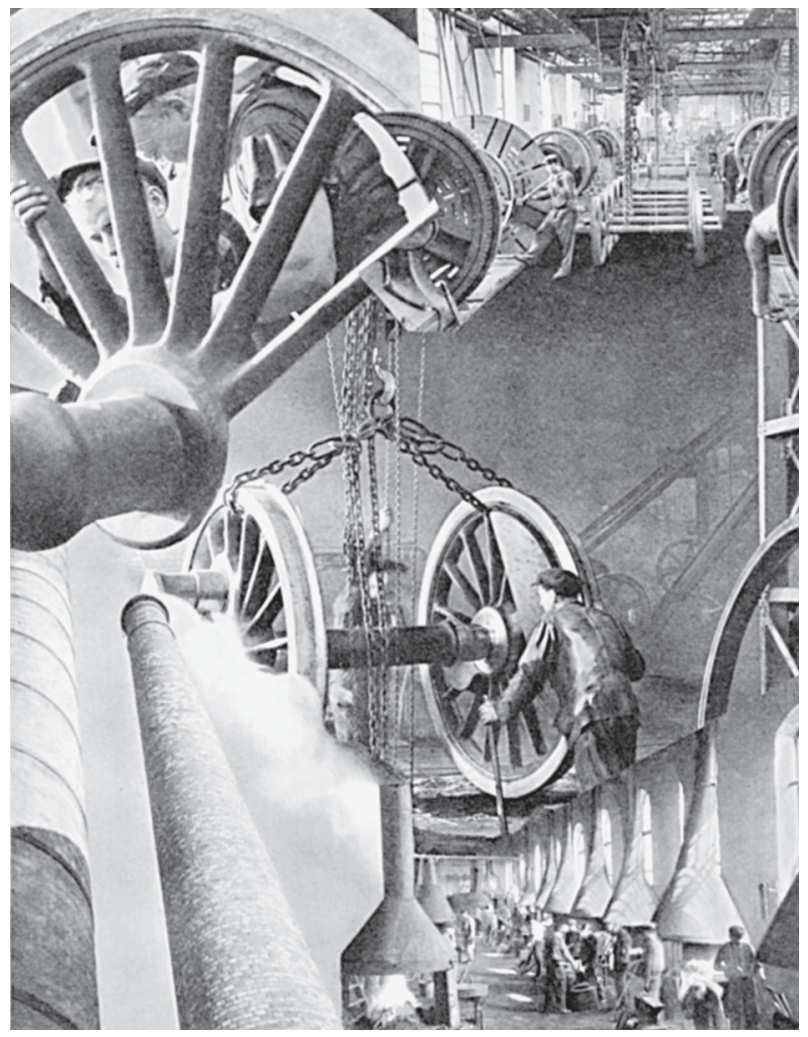

Fig. 66. Montage illustration in a publication promoting tourism (Ungarn - Magyarország 1937, Budapest, 1937)

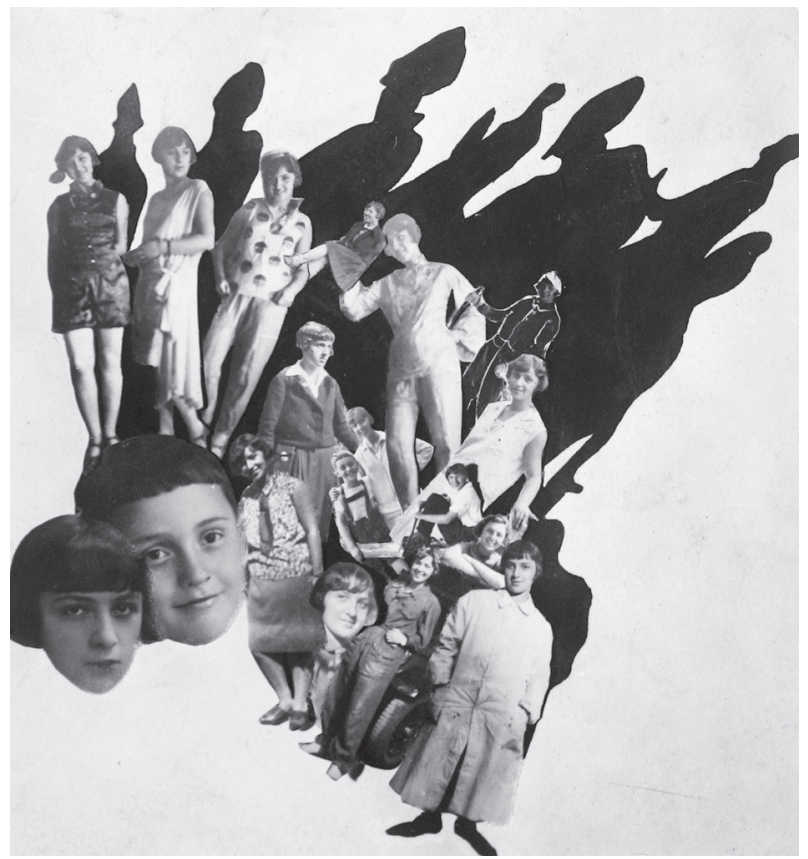

Fig. 67. Photographer unknown: Selfportrait, montage, c. 1930 (Vintage Galéria, Budapest) 
together as works which, while they could be given form with multiple layers, were ultimately ridiculous: "Some interesting subjects have been created, from which further variations could be made. For instance, buffalo hunting in the gallery of the Paris Grand Opera, which can be combined with acrobats performing on the head of one of the Indian hunters, etc." In Genthon's view, individuals such as Bortnyik and Grosz - whom he decried as "Merzist photo-gluers" - and later artists who incorporated photographs into their abstract constructions, produced works that the critic regarded as aberrations, because for him, the idea of uniting painted and photographic images into one artistic product was too grotesque. As he wrote, "Hitherto, only a few people have thought of using what are mostly painterly effects derived from copying sheets onto one another. Experimentation is going ahead in its own faltering fashion." ${ }^{221}$ Much less was spoken about the fact that manipulation has always been an intrinsic aspect of photography, which now, in the digital age, is recognised and accepted as obvi- ous. ${ }^{222}$ In the literature on Hungarian art between the two world wars, the artist who is most clearly regarded as embodying the principles of montage is Vilmos Aba-Novák, especially for the fresco he made for the Roman Catholic church in Jászszentandrás (1932), his mural for the Monument to the Heroes of Szeged (Heroes' Gate), and the giant murals he painted for the Exposition Universelle in Paris in $1937^{223}$ (Figs. 68-69). All three works were built around the logic of pictorial elements that could easily be distinguished from one another. The cityscape that Aba-Novák displayed at the first major group showing in Hungary of works by artists from the School of Rome, ${ }^{224}$ held at the National Salon in 1931, was also influenced by the "simultaneist" technique of Futurism and the innovations of the aeropittori (aerial painters). Of all the artists in Hungary, he was the one who most consciously aimed for the "modernisation" of fresco painting, and this was what gave him his true greatness. As he declared in 1931, "I say what I think: the future of painting is the wall." 225

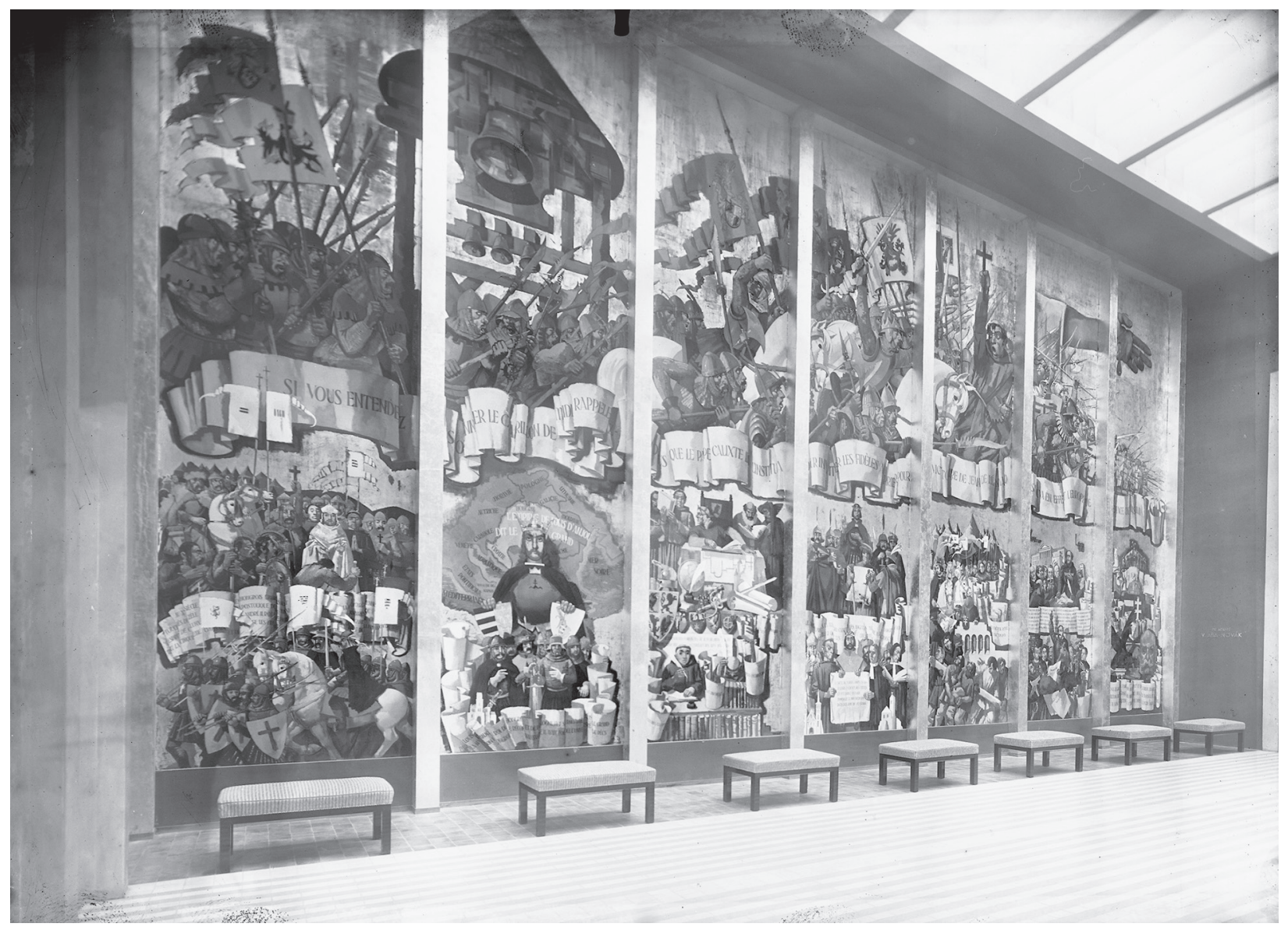

Fig. 68. Exposition Universelle in Paris, 1937, monumental painting "The Historical Connections between Hungary and France" by Vilmos Aba-Novák in the main hall of the Hungarian exhibition building

(photo: Studio Marius Gravot, Paris; MÉM 93.626; published in La Hongrie 1937. 36) 


\subsection{Photomurals}

Apart from Bierbauer's publications, I have not come across any other Hungarian works that deal with the photofresco in detail. I shall therefore approach the history of how the genre developed, or at least certain aspects of it, by looking at some foreign examples. ${ }^{226}$ The Exposition Universelle in Paris in 1937 (Fig. 70) is an inevitable starting point, since it featured unprecedented quantities of photomurals, to the extent that Gisèle Freund - who devoted a lot of energy to this genre - referred to it as an overemphasis, which threatened the effectiveness of the new medium. ${ }^{227}$ Opinions of the photomontages and photomurals exhibited in Paris were voiced by artists and critics including Gisèle Freund, Amédée Ozenfant, André Léjard, Mallet-Walton and Louis Chéronnet. Freund was in her early twenties when she emigrated to Paris from Berlin in 1933. She defended her dissertation on photography in France in 1936. In Paris she first met Walter Benjamin, whose devoted follower she became, although it was on the subject of photomontage that they held strongly opposing views. She, like several

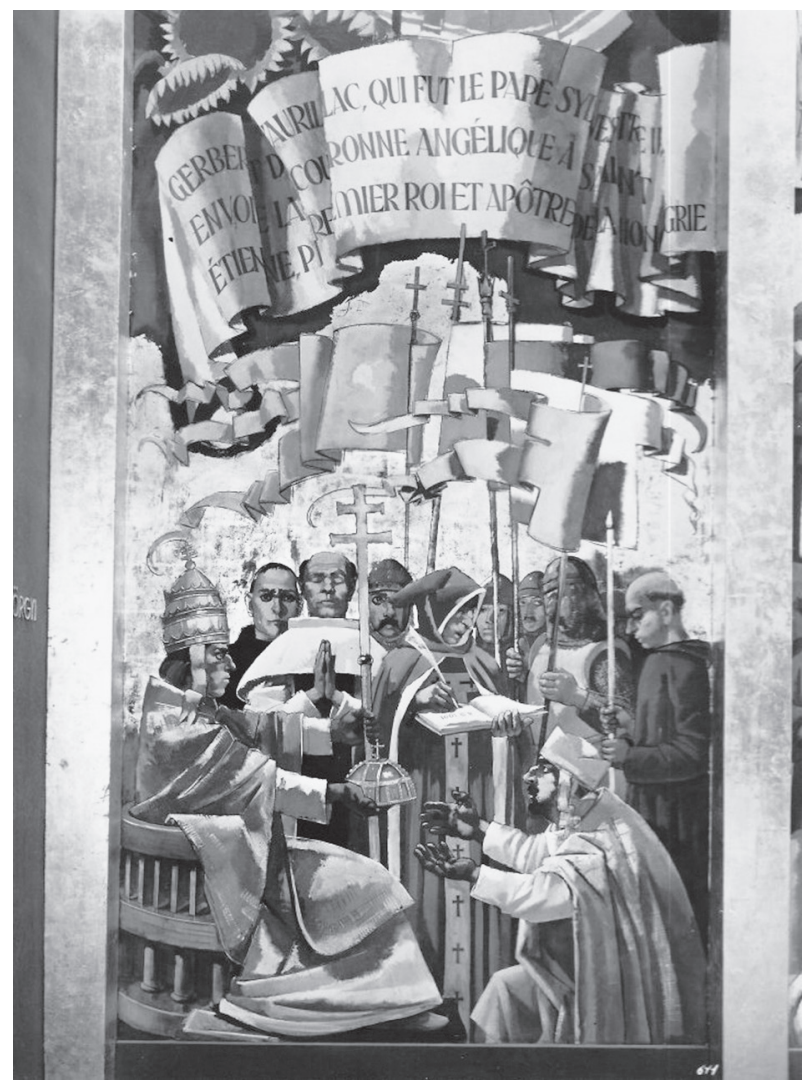

Fig. 69. Exposition Universelle in Paris, 1937, detail of the monumental painting "The Historical Connections between Hungary and France" by Vilmos Aba-Novák in the main hall of the Hungarian exhibition building (IPM FLT 7946) other commentators, attributed the intensive use of photography at the Exposition Universelle to the fact that it was the ideal tool for the modern transfer of information. The new products created by enlarging images, however, also raised the problem of magnifying the montage into a mural. Distinguishing between simple photographic blow-ups and photomontages, the photomontage is a picture composed without any recourse to material reality, which bears the imprints of certain thought associations and ideas. Through pictorial creations, new thought associations are generated in the viewer, and this, as a specific aim, was described by Freund with the term "thought control." Claude de Santeul, who was the most trenchant in his criticism of the montage technique, shared this opinion, mercilessly pointing out how the agencies and periodicals that dealt with making montages were ideologically sympathetic towards the dictatorial powers. ${ }^{228}$ Although these criticisms concerned real problems, political events had no direct effect on artistic quality, and there was no direct relationship of this nature between the two. What they did affect, however, was the form and the subject matter. Both Germany and the Soviet Union were pioneers in transforming enlarged photographs into political tools, and in the opinion of certain critics, the use of monumen-

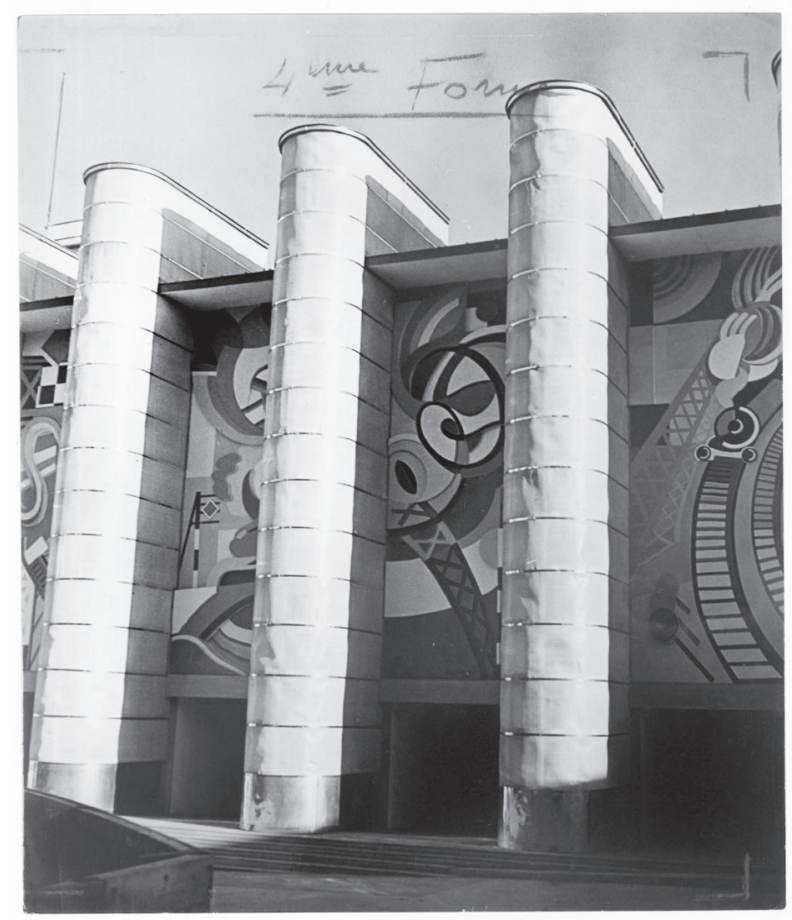

Fig. 70. Exposition Universelle in Paris, 1937, exhibition building with three pavilions, painted abstract murals on the main façade, around the entrances (photo: Pierre Verger, 1937; IPM FLT 24686-1) 


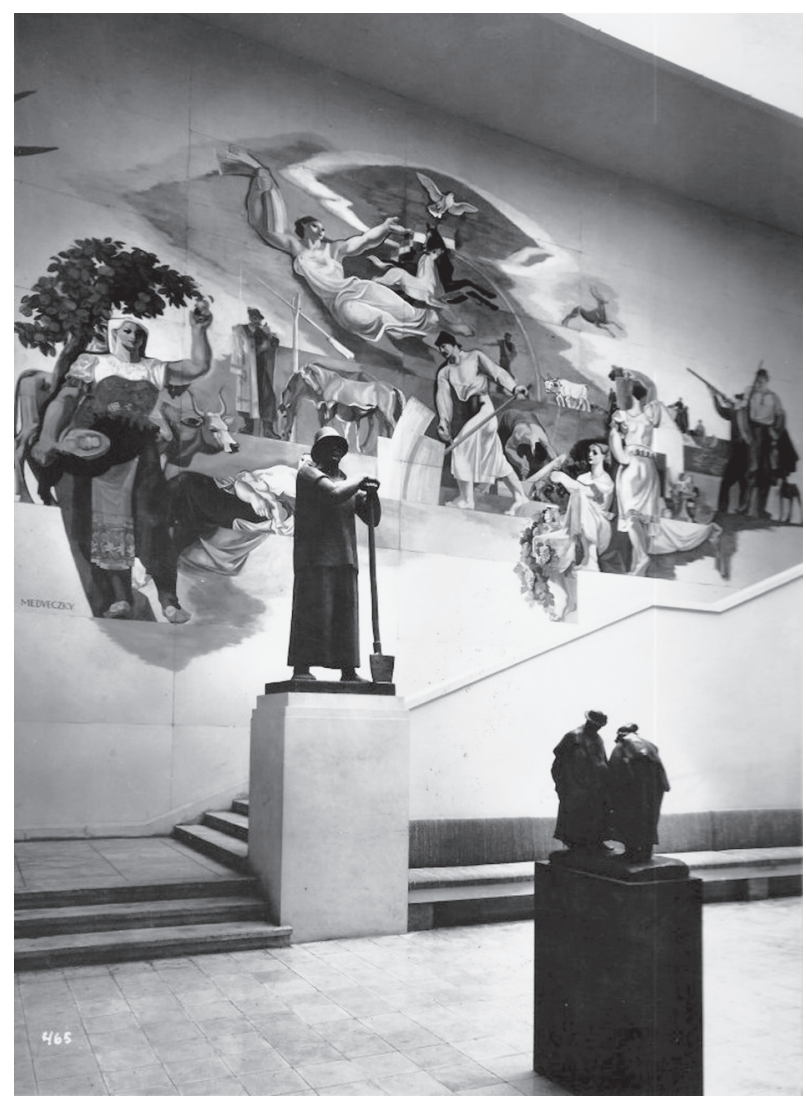

Fig. 71. Exposition Universelle in Paris, 1937, courtyard of the Hungarian exhibition building with Jenô Medveczky's mural "Hungarian Agriculture"

(photo: Studio Marius Gravot, Paris; IPM FLT 7926; published in La Hongrie 1937. 63)

tal photography was introduced in order to impress even more deeply in the minds of the masses the facial features of their leaders. The theory of realism that derived from Marxism was perfectly compatible with these images which, though they were taken directly from reality, were blown up to improbable proportions. Visitors to the Expo could see for themselves what a large proportion of the decorations inside the pavilions were made up of enormous photographs. One reason for this can be traced to the architectural characteristics of the pavilions, for temporary buildings provided the perfect surfaces for displaying information on a gigantic scale. The Photo-Ciné-Phono pavilion was interesting for a different reason, for the building itself perfectly reflected the shape of the equipment it was designed to promote. It resembled an enormous camera, and was covered with enormous photographs both inside and out. ${ }^{229}$

The conservative approach of the Hungarian pavilion and its exhibition concept at the Exposition Universelle left narrow bounds for introducing the

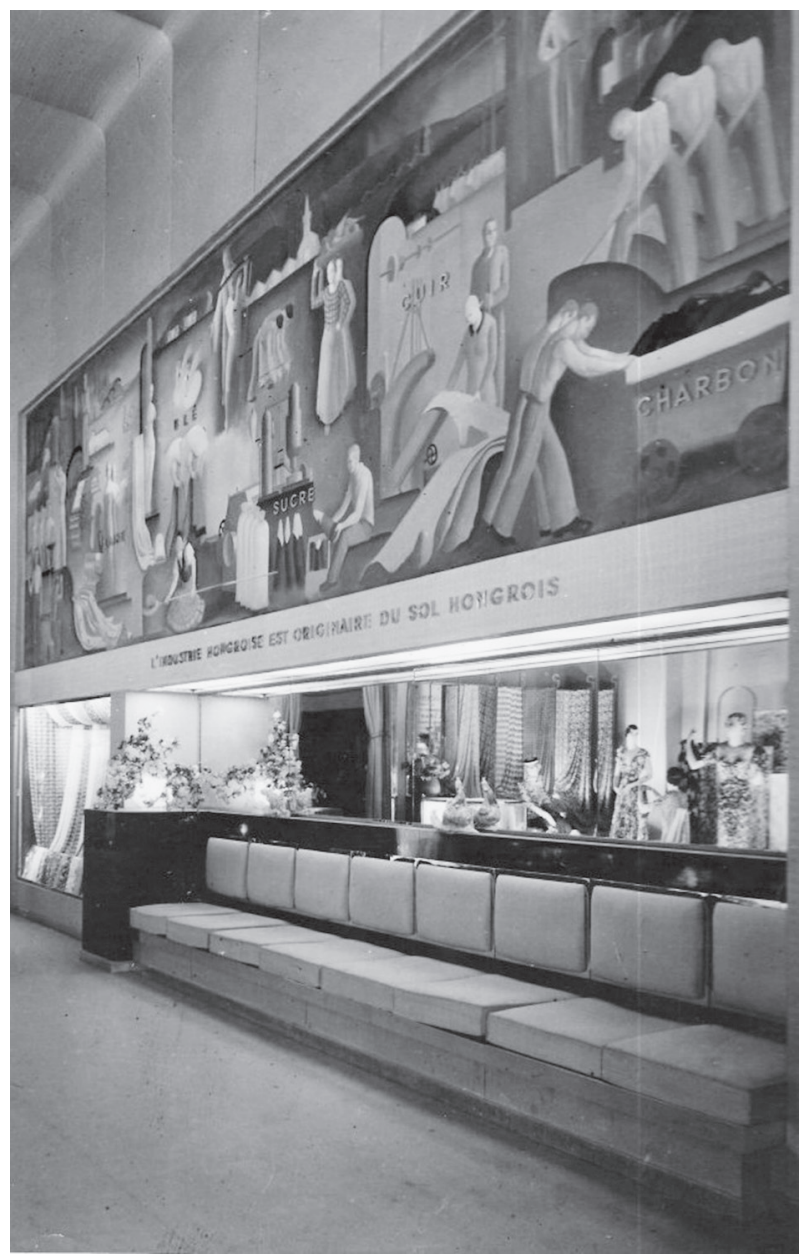

Fig. 72. Exposition Universelle in Paris, 1937, exposition of the Budai-Goldberger Textile Factory with the mural by Béla Kontuly "Hungarian Industry" in the Hungarian exhibition building (photo: Pál Veres A.; IPM FLT 7928; published in La Hongrie 1937. 61)

modern Hungary. However, in the halls of industry, agriculture, textile, transport the tool of murals was frequently used (Figs. 71-73).

Photographs on an enormous scale had already been seen before 1937 in both Paris and Berlin. In 1930, a famous photomural installation by Herbert Bayer (1900-1985), the greatest graphic artist at the Bauhaus, was exhibited in the Deutsche Werkbund room at the Salon des Arts Décoratifs. ${ }^{230}$ A year later, Bayer, Moholy-Nagy and Walter Gropius held an exhibition on urban planning ("Deutsche Ausstellung," Berlin, 1931), whose spectacle was also based on photographic illustrations and installations. Thanks to Bayer's continued activity after his emigration to the USA in 1938, the use of photomontage and enormous blow-ups enjoyed a renaissance at a variety of propaganda exhibition ("Road to Victory," 1942, "Airways to Peace," 1943: Museum of Modern Art, New York). 


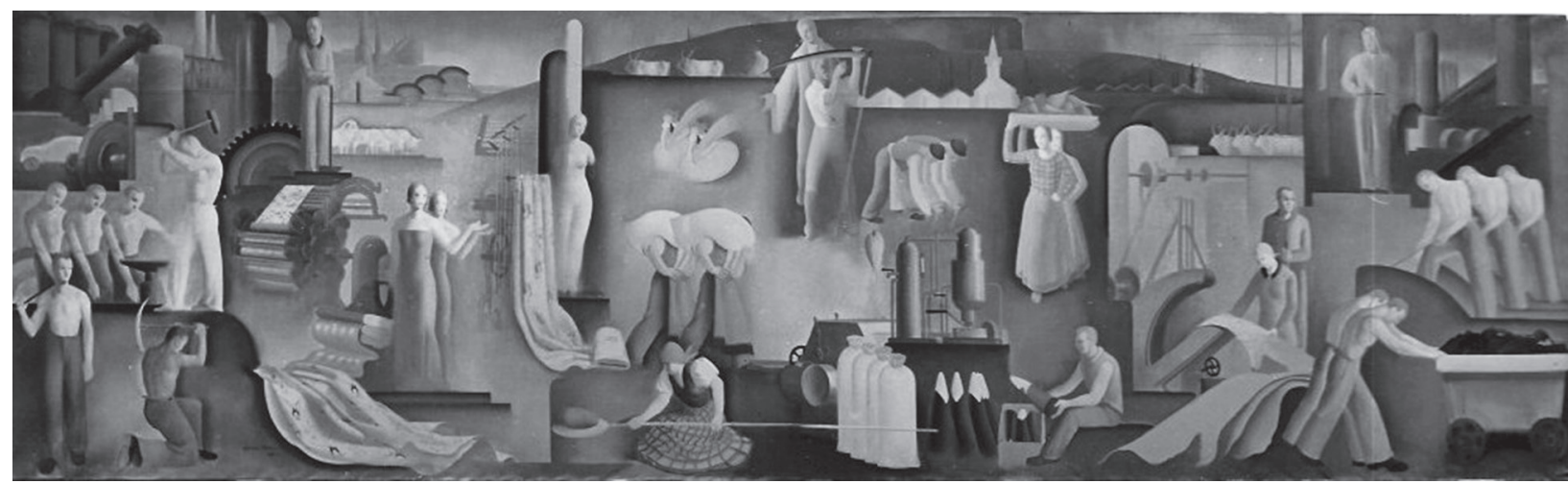

Fig. 73. Exposition Universelle in Paris, 1937, mural by Béla Kontuly "Hungarian Industry" in the Textile Room of the Hungarian exhibition building (photo: Magyar Filmiroda; IPM FLT 7927; published in La Hongrie 1937. 60)

Talented artists succeeded in making this medium a universal means of expression, and this led to new ways of designing the interiors at exhibitions in the 1930s and 1940s, first in Europe and later in the USA. Research suggests that the use of extremely large photographs played a major role in shaping the personality cult of Hitler's totalitarian dictatorship between 1933 and 1937; "Gebt mir vier Jahre Zeit!" (Give Me Four Years' Time!), held in Berlin in 1937, is regarded as one of the most complex exhibitions of its kind, where photomontages and photopanoramas became powerful tools for helping people to identify with the mythology of national socialism, similarly to the effect in Italy of the "Mostra della Rivoluzione Fascista" in 1932, to mark ten years of Mussolini's rule. 231

The photofresco competition announced in New York in 1932, inspired by the achievements of monumental Mexican murals, was an altogether different type of event. The 65 American artists invited to take part were asked to design horizontal photomural compositions measuring 21 inches in height and 4 feet in width, with the only other stipulation being they had to comply with the subject of the competition: "The Post-War World." The clear propagandistic aim of the competition was for the exhibition to raise awareness of how frescos could be used in modern architecture. ${ }^{232}$ This progressive initiative was intended to quell fears that the application of painted murals in modern interiors would diminish or destroy the space-expanding effect of blank wall surfaces. Since developments in synthetic materials and photoreproductive techniques had opened up new possibilities, the lower cost of photomurals and the relatively short time needed to produce installations led to a reassessment of previous criteria. Photographs pasted onto canvas or cardboard could be easily mounted on walls, and easily removed and swapped. Julian Levy, the curator of an exhibition on the subject held in 1969, listed three basic advantages to wall decorations: speed, economy and flexibility. ${ }^{233}$ It was explained that a good photomural was not the same as a mechanical enlargement of a small-sized photograph, because in the event of a poor concept or imprecise execution, photographs could completely lose their original identity and become virtually unrecognisable in new settings. In the case of a photomural, the main problems generally had nothing to do with editing the image or placing the details, but rather concerned the uncertainty surrounding the change in meaning of the composition as a whole that would inevitably come about as a consequence of the magnification. It was not always possible to predict whether an enlargement of a negative or a small picture would turn out to be as interesting as the artist imagined. A montage, by contrast, was an ideal way of taking fragments of photographs and assembling them into a large and visually spectacular creation. The majority of the painters and photographers invited to participate in the competition did not have the technical experience needed to create monumental photographic works, so many opted for the technique of photomontage. Many of the painters - including Henry Billings, Electricity in Modern Life; Glenn Coleman, Manhattan: Old and New; Ernest Fiene, Aviation; Stuart Davis, Abstract Vision of New York; Morris Kantor, Airways; Georgia O'Keeffe, Manhattan - worked on canvas, while actual photomuralists tended to employ the technique of montage, often making use of double exposure. The main exponents of the photomural were Berenice Abbott, Maurice Bratter and Arthur Gerlach. A number of artists earned commissions in the wake of the exhibition, including Edward Steichen, who not only worked for the Chicago World's Fair (1933), but also produced photomurals on the subject of aviation for the men's smoking lounge in the new Roxy Theater in the Rock- 
efeller Center. ${ }^{234}$ It has been clearly demonstrated how photomontages and documentary photographs played a practical role in building the image of the historical past in European nation states, and this can also be seen in the United States. Following the Wall Street Crash, all the way through to the 1940s, building at Rockefeller Center the American government successfully used photography to reinforce national identity and to persuade broad swathes of society to support their policy of economic stimulus. Although politically and politico-economically motivated montages were clearly in common use between the world wars, the genre of documentary photography would reach its true pinnacle at the "Family of Man" exhibition held at the Museum of Modern Art, New York, in 1955.

Despite all their abstractions, the photomontages and photomurals that replaced paintings remained fundamentally figurative artworks, with - in most cases - no need for explanatory texts in order to understand them. However, they were not in any sense veristic, and the essence of many such works was in the message of the montage rather than in anything real that was depicted. The main reason for the rapid rise in the popularity of the photomural was the technique's adaptability and potential for innovation. Photomurals could be produced relatively quickly and inexpensively and were easy to transport, which made them fundamentally different from other murals of a similar size. A further contributory role was played by the fact that photographs, as reproducible and printable media, could be enlarged and adapted almost at will, which resulted in revolutionary changes in visual culture, particularly in mass communication and propagandistic art. The monumentality of photomurals meant that they could satisfy the demands placed on them, which came about partly because their monumentality was an aid to understanding, and partly because the genre offered an adept combination of both decoration and propaganda. Among the artists who made photomurals can be found both avant-garde painters (Léger, Dufy, Picasso, Miró) and photographers (Gustav Klutsis, Josep Renau). As we shall see later, in England it was the interior design of cinemas that prompted the development of a new photofresco technique, with a solely ornamental objective. While the photomural flourished in avant-garde endeavours in France and Spain, and in advertising and propaganda in Russia, Germany and Italy, in the United Kingdom and the USA it was applied mostly to adorning modern architecture.
In the case of airports, as a building type, the changes they underwent can also be clearly traced from the 1920s onwards, as they developed into increasingly sophisticated communal spaces. Over time, the methods for decorating the surfaces of the walls in airports also evolved. As air travel opened up to the masses, the promotional materials and photomontages engendered by this newfound popularity often featured images of aeroplanes wrenched away from their actual environment: they were either shown alone, for example, hovering above landscapes and buildings, or were depicted standing out against a dense and varied composition, as a symbol of release. Sometimes just a part of an aircraft, such as a propeller or a detail of an engine, was placed in the focus of the image, representing technology in a broader sense. Photos of actual airports were rarely found in works of fine or applied art, but were restricted mainly to press reports and specialist periodicals. Budaörs was an exception to this rule, for a photograph of the airport constitutes part of the composition of the cyclorama (Figs. 74-75).

\subsection{The photofresco, a new form of mural}

The history of how the cyclorama in Budaörs Airport was created reinforced our idea that the genre of the photofresco remained almost unheard-of in Hungary, despite large murals being widely used for artistic purposes and even endorsed by official art policy (Figs. 68-69, 71-73, 76-78). This can be attributed to a lack of patrons willing to sponsor modern endeavours in photography in the same way as they supported other areas of the fine arts. Applied photography was not regarded as an art form, and regardless of the recognition that photographs of monumental size were ideal for decorating walls, the use of photomurals failed to spread in Hungary despite their sharing obvious roots with the genre of the fresco. There would, however, have been ample opportunities in the 1930s to experiment with the decorative properties of enormous photographic works. The cultural policy pursued by the minister, Kuno von Klebelsberg, in the 1920s meant that archaeological excavations, restorations of historic monuments and constructions of public buildings were often used for state protocol purposes, because of the connections that such places had with the nation's past. (A parallel can be seen in the restorations of ancient monuments in Italy under Mussolini.) From an art policy perspective, such public works led to a revival in monumental mural paint- 


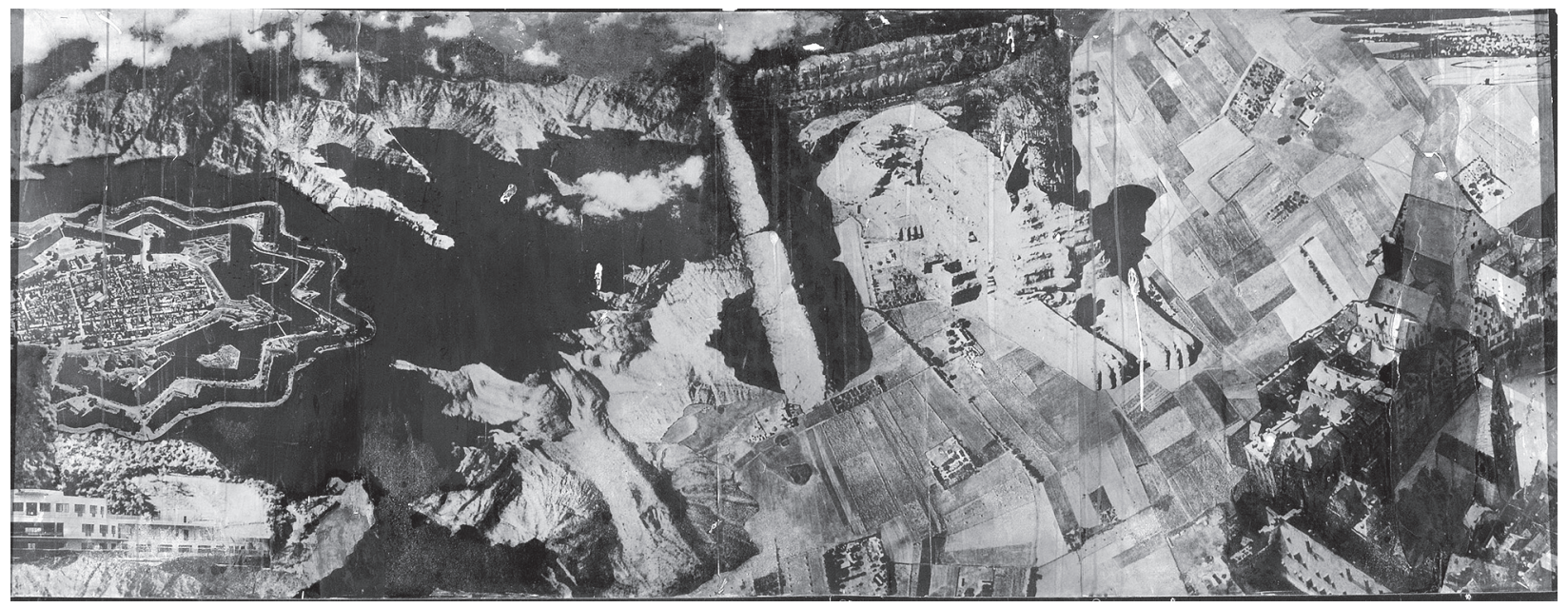

Fig. 74. Detail (section VIII) of the cyclorama "The Experience of Flight" by Mrs Elemér Marsovszky with the photo of Budaörs Airport in the lower left corner (photo: András Ágh, 2006)

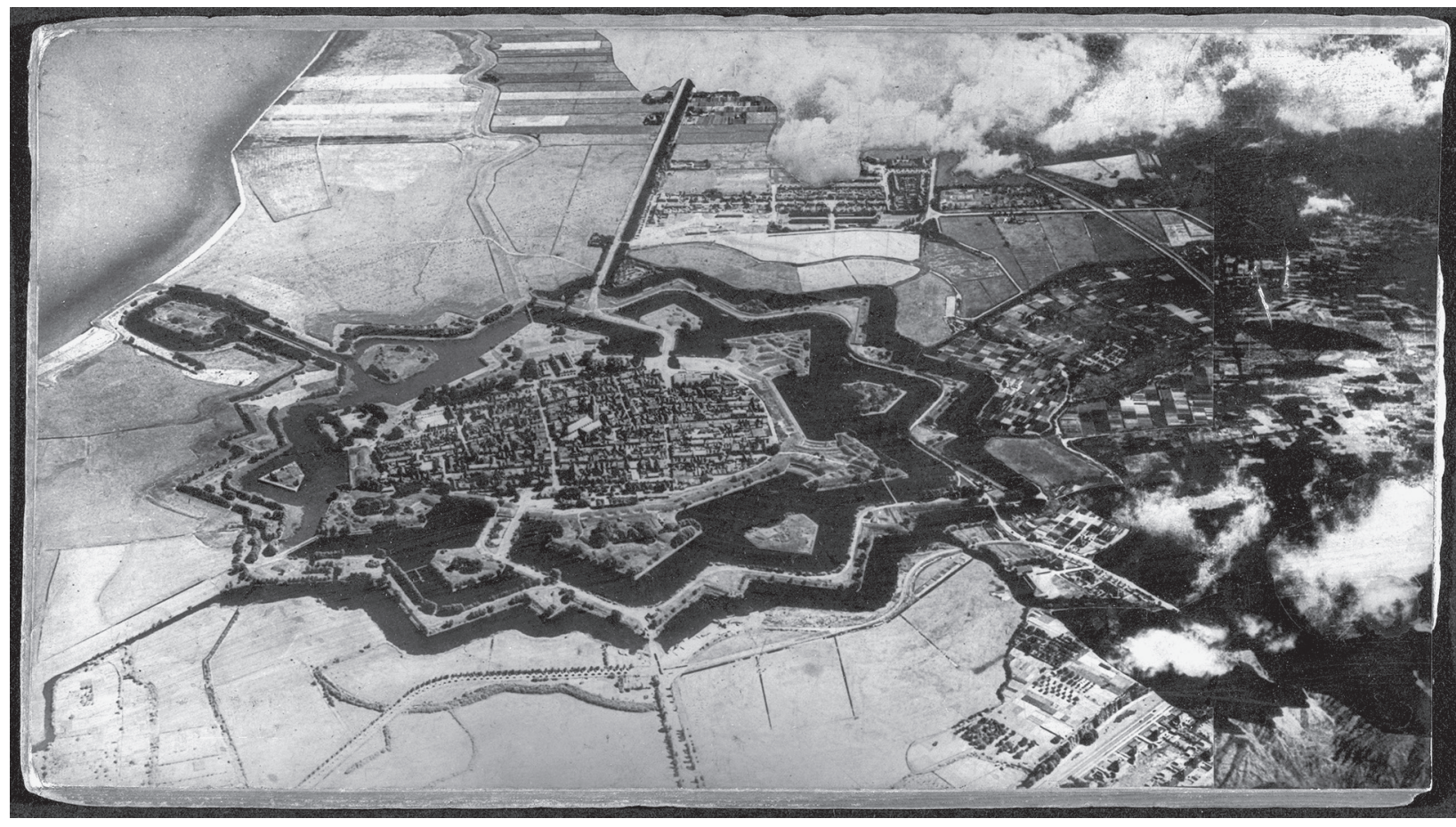

Fig. 75. The original plan for a part of section VIII of the cyclorama without Budaörs Airport (photo: Mrs Elemér Marsovszky, 1937; MÉM Borbíró-hagyaték GYN: 659)

ing. Modern research points out that in the interwar period, under the leadership of Miklós Horthy, there was a demonstrable link between, on the one hand, the reconstruction of monuments and the celebrations or ceremonies held in connection with them, and the desire to establish places of national memory. ${ }^{235}$ Among the largest projects at the time, in 1936, in preparation for the approaching 900-year anniversary of the death of the founding Christian ruler of Hungary, King Saint Stephen (†1038), work commenced on excavations (Royal Castle Palace, Esztergom) and on the conservation of ruins (Royal Provostry, Székesfehérvár), as well as on the construction of the Mausoleum of Saint Stephen in the Garden of Ruins in the erstwhile coronation city, Székesfehérvár (1938). Vilmos Aba-Novák, who painted the murals in the mausoleum, was asked especially to include portraits of certain well-known modern-day politicians - including Miklós Horthy, Bálint Hóman and Béla Imrédy in the cycle of paintings dealing with the history of the Holy Crown of Hungary (Fig. 78). Interestingly, at the time the artistic concept was being devised, in the gen- 


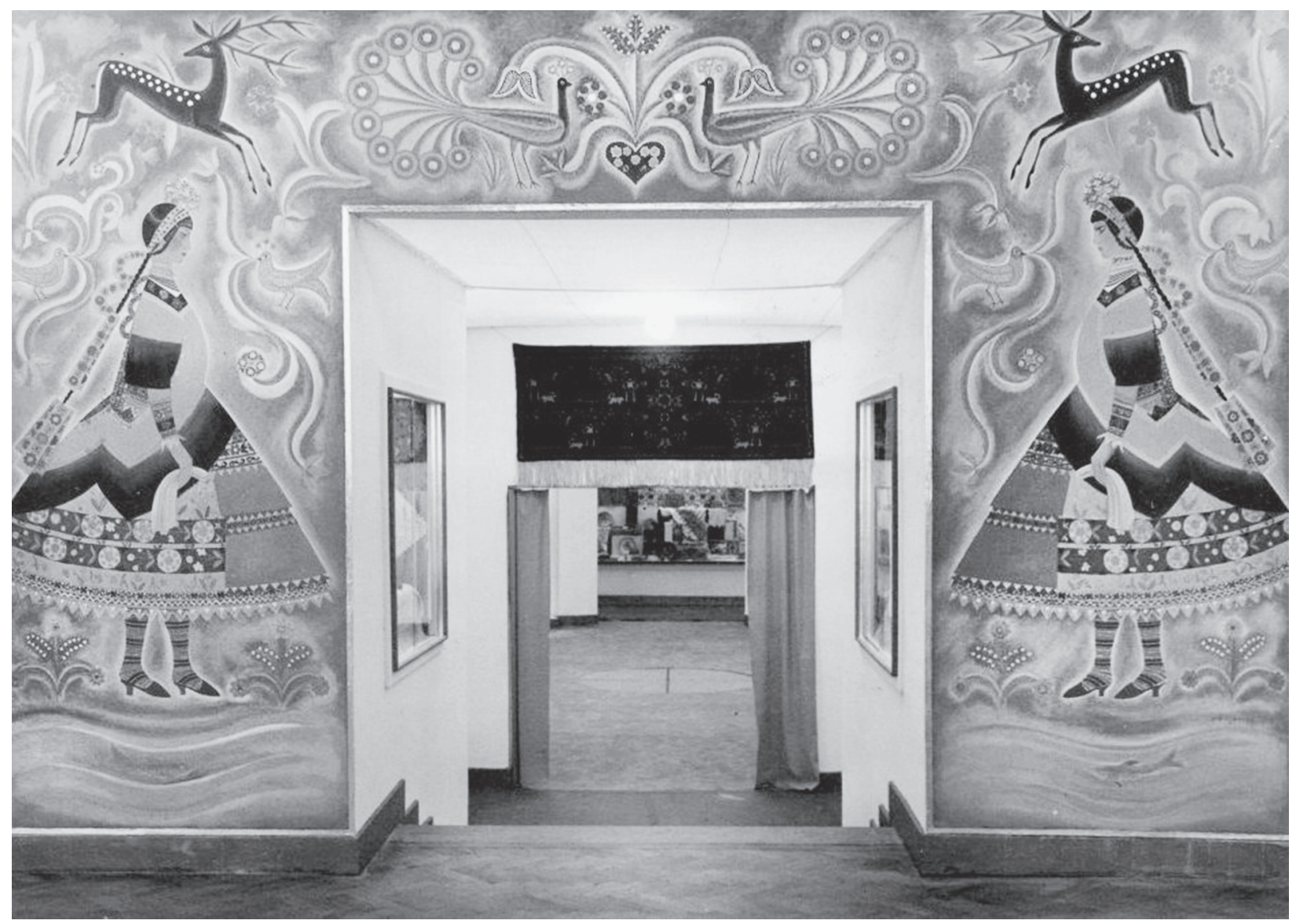

Fig. 76. Jubilee exhibition for the 50th anniversary of the National Hungarian School of Applied Arts in the Museum of Applied Arts, Budapest, design: György Kórody, murals by Antal Diósy, 1930 (IPM FLT 24437)

eral approach towards the roots of art and its modern social role, photography was regarded as insufficiently ceremonial, and there were also fears about its technical durability. A ministerial memo dated 25 August 1938 gives an indication of the objections that people had against photography when it came to organising the celebrations in Székesfehérvár: "The great events of the Memorial Year of Saint Stephen have generated great interest across Europe. The celebrations held this year were not only magnificent visual displays but also represented a nation in deep contemplation of its own soul. It is for this reason that the events and historic ceremonies of this year must not be allowed to pass without a trace. Photographs and moving pictures, which are vulnerable to destruction, and newspaper articles that are soon forgotten, are unable honourably and lastingly to preserve the splendour and significance of the celebrations for Hungarians in future centuries. These great events, with their historic atmosphere, are best immortalised by the creative brush and chisel of the most excellent artists." 236 By twist of fate, just a few years later, Aba-Novák's frescos began to suffer destruction on the side of the mausoleum that was most exposed to the elements.

A wealth of examples, both from inside Hungary and beyond, demonstrate that when deciding on the technique and size of a picture, the needs and expectations of the given period played a vital role. The sig-

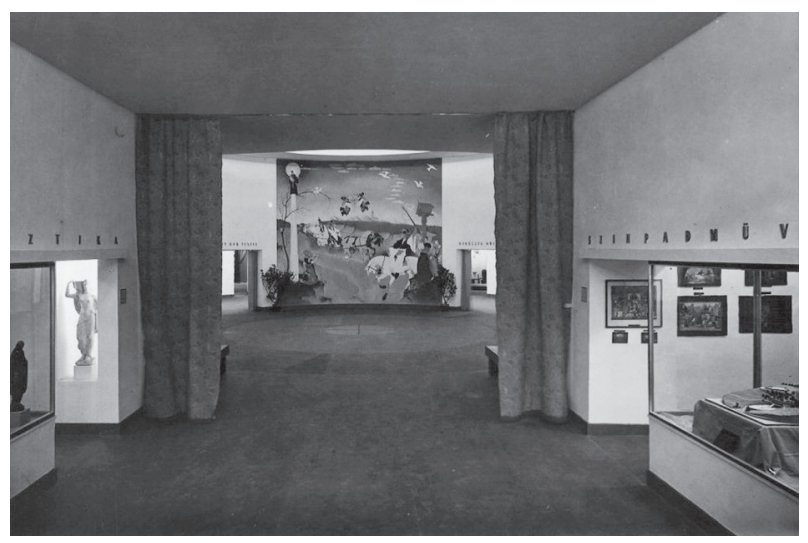

Fig. 77. Jubilee exhibition for the 50th anniversary of the National Hungarian School of Applied Arts in the Museum of Applied Arts Budapest, design: György Kórody, mural by Barna Basilides, 1930 (IPM FLT 22781) 
nificance of monumental art, which became a key concept between the wars, is shown by the fact that the art handbook edited in 1941 by István Szônyi included a section where the techniques used for monumental art were defined for each branch of the arts (except photography). Szônyi, one of the most important artists of the period, asked Pál Molnár C., a graduate of the School of Rome, to write the texts. ${ }^{237}$ According to what he wrote, every work of monumental art was expected to be an integral part of the building, to cover a large surface area, ${ }^{238}$ to enhance the dimension and grandeur of the building, and thereby underline the monumentality of the subject matter. The largest works of this kind appeared in ecclesiastical art and in the architecture of public buildings (Fig. 79).

The impregnation technique for producing photomurals, in which a wet emulsion is applied to the dry wall, with the image later being developed after exposure, most closely resembles the secco technique or mural painting, where the pigment was applied to plasterwork after it had dried. The "wet process" played a major role in the early days of photography. The emulsion was poured onto the glass plate, and the image had to be exposed while it was still wet, otherwise the negative would lose its light-sensitivity. This was revolutionised in 1871 when Richard Leach Maddox invented lightweight gelatin negative plates, which became the standard over the next few decades. But to return to the topic of photomurals, according to Claude de Santeul, writing in 1937, there were two basic ways of making mural-sized photographic compositions. The most frequent method was to reproduce a number of different prints onto standard-size photographic paper, and then to paste them onto the wall, like wallpaper. The other, far more complicated technique involved applying a light-sensitive emulsion directly onto the surface of the wall, after which the negative would be projected onto it, followed by developing, fixing and polishing. ${ }^{239}$ Exhibition halls and pavilions tended to be decorated with large photomurals and photomontages produced using the former method.

\subsection{The birth of cinema decoration and photomurals}

We have already stated, in connection with Bierbauer's correspondence, that he was aware of the work of Michael Egan and Eugene Mollo, although there is no trace of any direct contact in his estate. We therefore also need to mention the February 1937 issue of Archi-

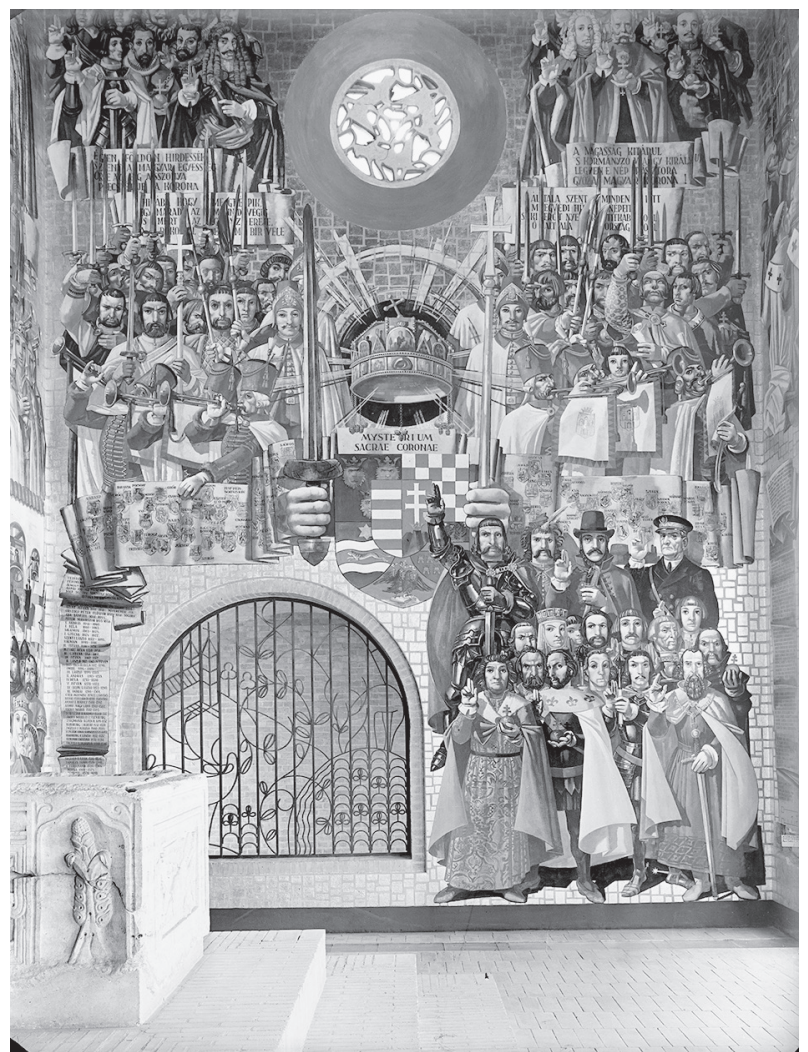

Fig. 78. Székesfehérvár, Saint Stephen's Mausoleum with murals by Vilmos Aba-Novák, 1936 (MÉM 17.453.)

tectural Review, which provides a detailed account of the photofresco technology they invented and of its importance in interior design. 240 The supplement (Decoration, the Architectural Review Supplement) briefly discusses the versatility of the photofresco, while the chapter titled "The True Photo-Mural: A New Technique of Decoration" outlines how such images are created. According to the lead-in text, the first stage was to coat the surface to be decorated with a sprayon, sensitised photo-emulsion. Care had to be taken at this stage to ensure the emulsion was evenly applied over the surface of the wall. Using a spray gun was a more effective guarantee of this than working with a brush. In the last two stages of the process, the latent picture needed to be developed and fixed, again done by spray application of the chemicals. As with conventional photographic methods, almost the entire process had to be conducted in perfect darkness by the makers of the photomural, who worked in situ. In order to demonstrate how the spectacle depended on the substrate, they used a portrait of an ancient statue of a man, the effect of which was substantially influenced by the texture of the substrate. They used a wide range of substrates, from corrugated aluminium to canvas, and from plastic to cardboard sheets of varying 


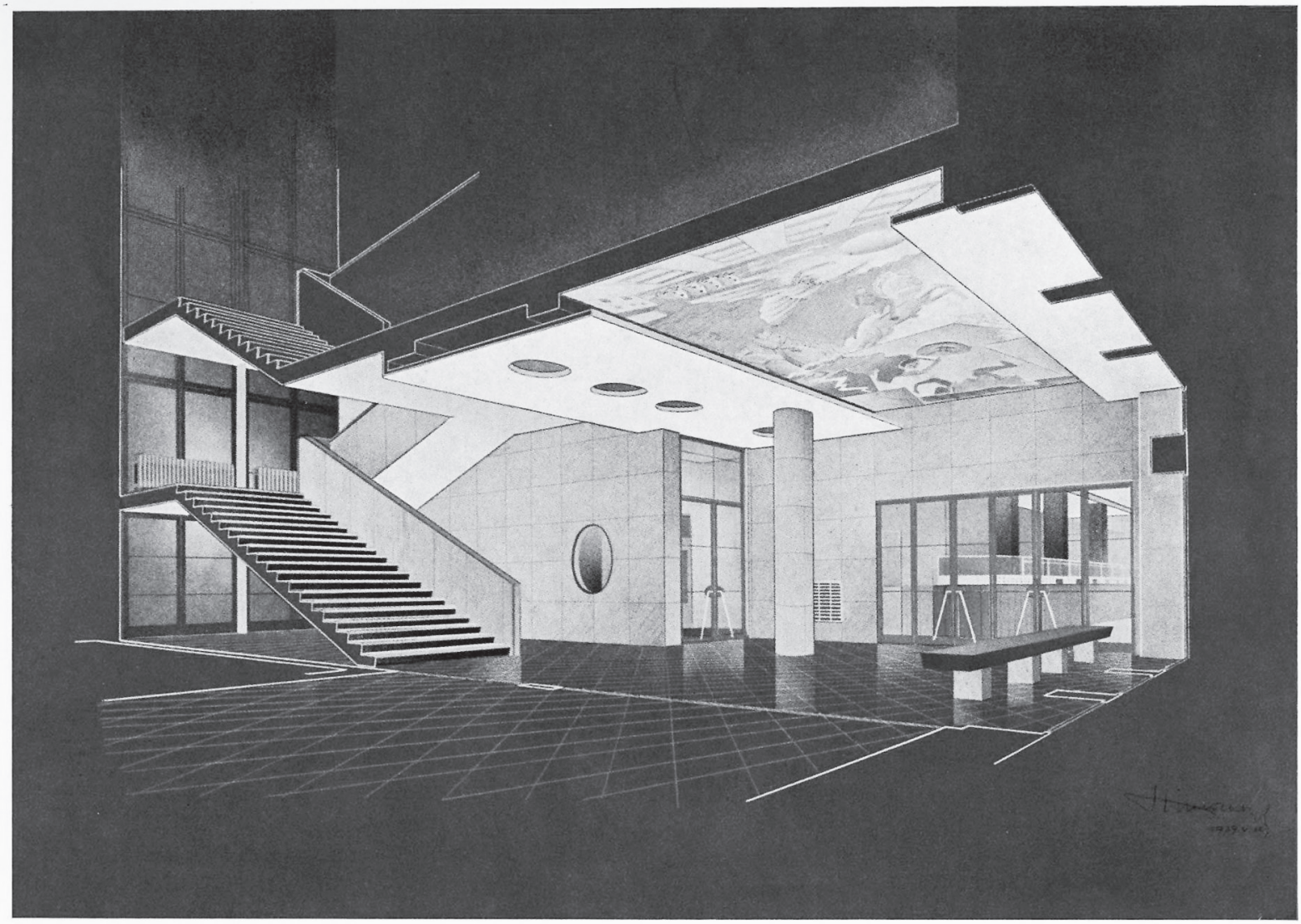

A Budapesti Posłaigazgatóság előcsarnoka.

Tervezte: Rimanóczy Gyula.

Freskó: Molnár C. Pál.

Fig. 79. The colour visualisation of the lobby of the Budapest Post Office Directorate building

(75-81 Dob Street, 7th district, architect: Gyula Rimanóczy) printed as propaganda material, with design for the ceiling fresco by Pál Molnár C., 1939

thickness. ${ }^{241}$ The article presents quite a few examples already implemented in England, such as the abstract picture decorating the interior of the Lansdowne News Theatre, a cinema in London, a few photofrescos at an exhibition in Charing Cross Underground Station, the exhibition advertising the new Earl's Court Exhibition Buildings (designed by E. McKnight Kauffer, who also designed the photofresco in Embassy Court in Brighton) and the mural in the bar of Victoria Coach Station. The article features the same photograph of the hall in Embassy Court (Fig. 80) that was first published in the Hungarian press by Bierbauer. ${ }^{242}$

The most detailed information I could glean about the career of Mollo and Egan, and about the works produced jointly by the two men, who were both originally from France and both well versed in the modern trends of architecture, came from an interview conducted with Egan in 1998. ${ }^{243}$ The work they were responsible for under the company name of Mollo \& Egan leads us into the unique world of wall decora- tions and lighting techniques used in film theatres, which formed the starting point for their invention of a new mural-making technique. Their work shows that, although the substrate surface and composition of the photofresco were derived from historical painting techniques, the direct origin of the photofresco lies not in grand painting but in the decorative demands of architecture. At the same time, the focus here, as with historical mural painting, was on decorating the walls, which was a new direction in modern architectural thinking, one that even went against its original principle of leaving the walls unadorned. The theoretical aspects of this problem had been the subject of debate at the afore-mentioned Volta conference. In this instance, the basic material of the technique was photography itself, which - together with film - was one of the most modern means of visual depiction around. Mollo and Egan tried out their experiments in movie theatres, a type of building that had never previously benefited from well-planned interior design or 

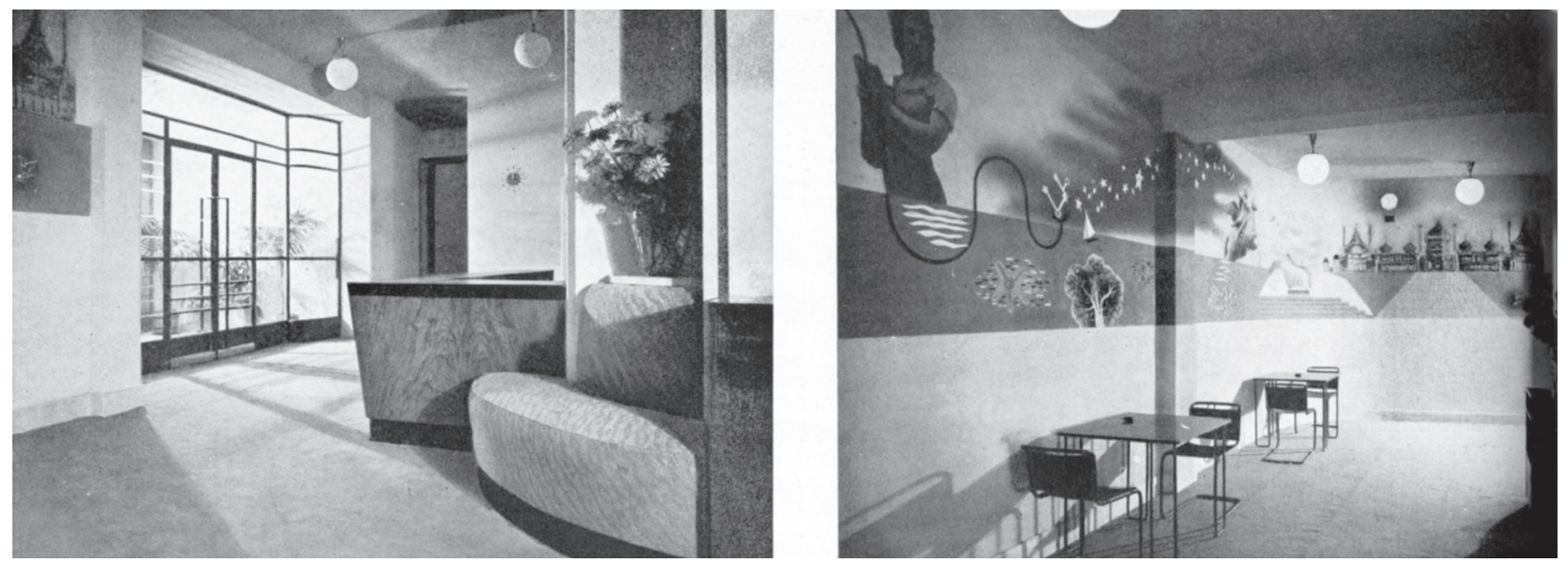

Fig. 80. The lobby of the Embassy Court in Brighton (architect: Wells Coates) with murals designed by E. McKnight Kauffer, made with the help of patented photo mural technology by Egan and Mollo, 1934

(photos published in Tér és Forma 9. 1936. 122)

surface decoration. Realising that here was an opportunity for them, Mollo and Egan decided to focus less on the architectural aspects of cinemas than on different decorative solutions (Plaza Worthing, Plaza Sutton). The friendship between Mollo and his younger colleague Egan had begun in the 1920s, when they were working in England for the French firm Marc Henri \& Laverdet Ltd. During their years with this company, Egan was the first who tried to branch out on his own, and in 1931 the two men together drew up the designs for the Dewsbury Playhouse cinema (architect: Robert Cromie). Their bosses were not at all pleased with these attempts at independence, and this fact, compounded by the ever decreasing work opportunities, led the two French architects to return home for a while. Mollo now worked with upholstery and made spray-painted murals, while Egan took a greater interest in decorative sculpture and the design of lighting. They wrote an article on this special area that was published in a 1932 edition of Architectural Review. ${ }^{244}$ Egan's interest at this time was in how artificial lighting could be designed as an attractive visual element of the architectural space. Modern cinema interiors were ideal testing grounds for such endeavours, where decorative lighting solutions highlighting internal forms paid off thanks to the size and function of such spaces. The cinemas featured in the periodical (Odeon and Yeovil) had auditoriums with parabolic spotlights that combined form and lighting almost as a unified whole. The meeting point between the illuminated surface of the roof structure, hanging over the top of the stage, and the shaded parts of the auditorium, was, in the opinion of the writer of the article, sufficiently effective to be described in itself as a deco- rative motif. The first company the two artists founded together, $\mathrm{M}$ and $\mathrm{E}$ Equipment Ltd., was established in the early 1930s; in his old age, Egan compiled a photo album of the work they did together, featuring a series of exquisite and rarely seen images. ${ }^{245}$ When the man conducting the interview, Allen Eyles, saw the pictures of the enormous wall surfaces, the internal spaces with their concealed lighting elements, and the mutual harmony between the decorated floors, the ceilings and the murals, he concluded - and wrote at the end of his article - that the history of cinema architecture and design deserved to be rewritten. ${ }^{246}$ The first photofresco mentioned in the article written by Eyles is the one at the Lansdowne News Theatre in London, which opened in 1937, ${ }^{247}$ and there are three pictures in Egan's album that show the building's interior, one of which features the photograph of the classical male statue that appears on a recurring basis. ${ }^{248}$ According to Egan, they worked with a spray gun on this project, and after applying the emulsion, they developed the photographs in a darkened room, similar to an actual photographic darkroom. For the decoration of the Embassy Court in Brighton, the entire process was conducted on site, including sensitising and developing the substrate, which added substantially to the cost and complexity of the project. In Brighton they collaborated with McKnight Kauffer, who designed the mural for the vestibule. A "painting" by Maxwell Fry in an electricity switching station in London was made using the same technique. ${ }^{249}$

Whereas artists using the traditional fresco and secco techniques have always needed to work around and adapt to the pre-existing space, structure and surface, one of the benefits of the photofresco is that it 
enables the subsequent application of a planar surface. Here, as Mollo and Egan were not exposing the image onto pre-manufactured photographic paper, an additional layer to their work, distinguishing the photofresco even further from mural painting, was added by them consciously highlighting the texture and relief-like surface of the substrate (specifically, in this instance, the wall). Bierbauer summarised the advantages of the process: "Undoubtedly, with this technique photofrescos can be made even more interesting, because instead of the even surface of paper, the textural effects of the different renderings or wall surfacing materials can be incorporated into the artistic aims." 250

Bierbauer's only publication dealing with photographic art related to the cyclorama in Budaörs Airport was titled On the Photofresco (A fotófreskóról, 1937). In the illustrations, he refers to one section as "New York-Rome-Hévíz-Szeged" and the other as "Siófok-Schönbrunn-Venice-Tihany," which is important because this is the only place where he identifies the sections using place names. The publication also contains a detail from a photograph of the photofresco in Brighton that gave him the original idea for the work, although here he only mentioned the names of the designers and producers: "Room decorated with a photo-mural (design by Kauffer, Mollo and Egan.) Brighton" and "Photo-mural experiment by E. Mc. Knight Kauffer." 251 Regarding when he first came across the Englishmen's invention, Bierbauer

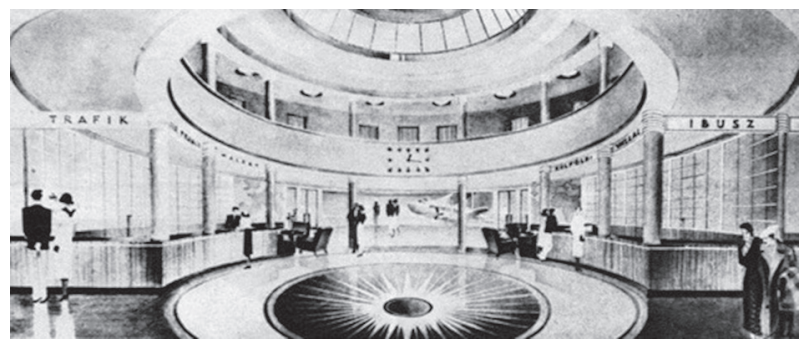

Fig. 81. Perspective view of the waiting room of Budaörs Airport's terminal building

(published in Magyarság 1936. december 25., 8)

wrote, "When the photofresco for Budapest Airport was mostly ready, we learned that in England a special process had been developed by the name of 'photomural', with which the photofresco could be projected and fixed straight onto the wall, and that they had already made some rather interesting murals using this technique."252 From his correspondence it is apparent that from as early as 1935 Bierbauer was looking for novel ways of decorating interiors, and we also know that the question of how to decorate the hall was a dilemma he spent a long time deliberating. This is also indicated in a visualisation he published at the end of December 1936, showing no decoration at all on the balustrade of the waiting room, only a clock ${ }^{253}$ (Fig. 81). Putting things together chronologically, he took his final decision on how to decorate the balustrade after returning home from Italy in November 1936, after which he attempted once more to make contact with Mollo and Egan.

\section{THE PHOTOMURAL OF BUDAÖRS AIRPORT: "THE PHOTO-FRIEZE, OR IF YOU PREFER, PHOTO-FRESCO"254}

\subsection{Choice of genre and technique}

While the Exposition Universelle in Paris burgeoned with photomontages and photofrescos, the photofresco in Budaörs Airport was the only example of its kind in Hungary. As the Hungarian press, even specialist periodicals, published nothing at all about the foreign precedents, Bierbauer's writings are our only source of information about the artistic concept of the path leading to the creation of the cyclorama, and about the technical processes by which it was made. ${ }^{255}$ As good a starting point as any for analysing the cyclorama is the fact that the composition was essentially designed to promote air travel by evoking the experience of flight, and the devices it made use of were connected to this. The following excerpt provides a vivid explanation: "The subject is one of great interest to people today: whoever flies will feel close to the subject matter of the mural, and whoever does not yet fly will be excited by it and inspired to try out this wonderful experience." 256

Architecturally, the modern shape and simple elegance of the airport accentuated the impact of the monumental artwork, which was composed of blownup black-and-white photographs. It is worth recalling that when he designed the terminal building, Bierbauer was guided, from beginning to end, by simplicity of form, and could only achieve his desired aesthetic impact by using modern design, free from all extraneous ornamentation. The beauty of the building's exterior was derived from the dynamic interweaving of masses and the varied interplay of straight lines 
and curves. Inside the building, as Bierbauer wrote, "the rich spatial life of the great hall also had no need for the kind of decoration that was customary in the past." The exception to this was the upstairs balustrade wall, which almost cried out for some kind of decorative motif or spectacular composition of imagery. ${ }^{257}$ An overview of Bierbauer's career and wide-ranging interests suggests that the cyclorama meant more to him than an ornament in a harmonious space. In this work, in addition to the national and architectural propaganda messages, it is also possible to discern a means of relieving the tension that arises in the human psyche from the perspective of passengers about the take to the air. It also contains a sense of the conviction that drove the designer in his efforts to follow modern ideas of arranging and shaping space. Even when "The Experience of Flight" was being planned, the technique of the photomontage, whose background will be described below, seemed the perfect choice for artistic expression, which is why it fitted in so well with such a tastefully designed public building. Bierbauer wrote several times about his specific demands for quality. There is a theory stating that of all the photographic techniques of the twentieth century, this one was particularly suitable for expressing how impossible it is for working with the negative to be completed, which is a fundamental ontological cornerstone in photography. ${ }^{258}$ In the case at hand, this theory manifested itself mostly in the tremendous freedom to arrange and organise the photographic prints at will. We have no information about the process of obtaining official permission for the cyclorama, although a few passages in the architect's writings suggest that it was not without its problems. First and foremost, it was up to Bierbauer to explain the use of modern technical media, such as photography and film, and why he thought it was suitable for this purpose: "Because there is no doubt that the photograph, despite being made by machine, possesses all the possibilities of works of art. [...] Could it be, I wonder, that those who so loudly disdain photography do so out of pride in their artistic knowledge rather than out of sincere artistic belief?"259 Elsewhere he writes, "Of course there were objections on the grounds of artistic policy! Some claimed to be offended by the exclusion of 'artist painters' - but, I asked, is the successful creation of a large-scale composition such as this not art? Is it only art if it is made with pencil and brush? Is an artist who uses the modern tools of technology less of an artist than one who only uses tools from a thousand years ago?"260 There is no evidence, but it is tantalisingly possible that the conservatism he came up against in official Hungarian cultural policy made him all the more determined to insist that the photofresco be made by a photographer who had previously been trained as a painter. ${ }^{261}$

The photomontage was executed in several stages, with the photographer first making up a maquette; after a few modifications and final approval, work began on composing the different chosen images together. Then came reproduction of the montage details, enlargement to the actual size, alignment, lamination, retouching and - at last - installation. The end result was influenced by the available budget, of course, although only the total sum is known, from the official report on the building. When the competition was announced, one of the requirements was economy, and this worked in favour of a photomural, which cost far less than a painted work. Whilst I do not believe this was the sole factor, I would be willing to bet that the price, as well as the shortage of time, played a role in the decision. This is substantiated by an American publication on photomurals from 1936, which highlighted the benefits of low cost and quick completion. ${ }^{262}$ In the Division III (Construction Affairs) Index Books (Mutatókönyvek) of the Budapest Municipal Council Documents, I could find no trace of the fresco being represented as an independent work. The permit procedure probably took place in spring 1937. The procedure was simpler than in the case of works of art presented before the National Council of Fine Arts, because decorations on public buildings were judged by officials.

When selecting the ideal decorative technique, the 105-cm height of the balustrade had to be taken into consideration, although when the frescos were created, the size and curves of the surface posed no obstacle. Nevertheless, the classical landscape and the figural fresco were both rejected. The initial ideas also include the genre of the poster frieze, but in the end - to quote Bierbauer's own words - the commission to decorate the wall was not given "to the master of poster-pasting who happened to be passing that way." 263 The subject of aviation and the experience of flight, which was closely connected to the function of the building, required a more serious approach, which led the designers in the direction of the painted fresco. This suggestion proved to be technically impossible to carry out, and what is more, Hungary did not have any exponents of aeropittura, the Italian school of aerial painting, who had the necessary experience to compose a work on such a theme. Bierbauer did not refer to aeropittura by name, but it is clear from his 
writing which movement he was referring to. He even briefly summarised what it was that made an artist an aerial painter: "In Italy there would be a whole team of painters available to fulfil this task. In these painters' pictures the optical experience of flight is evoked, its unique, intensely dynamic opticality. Sadly it must be said that the state of flying in Hungary means that one would be at pains to find a painter who had experienced such things, that is, one for whom the opticality of the aeroplane had become a sensory experience, for it is not enough for somebody to go up in a plane just once or twice, specifically for this purpose; the sense of flying can only belong to a person, even to a pilot, after frequent, sustained practice." 264 The idea of pictures that presented the aeroplane as a technical construction was also raised, although this could only have reproduced the plane as flying equipment, with no chance of conveying the philosophy or spirit of flight (Fig. 82). Another proposal was for a painted frieze showing flying figures from mythology (Fig. 83), but this was also discarded on the grounds that it would not have offered a sufficiently powerful "message of the true, deep-down experience."265 The surrealistic effect of "The Experience of Flight" and similar works is engendered by the cutting technique of montages. There are some succinct passages in Bierbauer's writing that deal with montage's origins in film: "One of the most essential aspects of making a film, perhaps the most important, is the 'cut', when the natural recordings are cut up and pasted together, enabling the director to create new, expressive associations. The technique of producing artistic talking movies is essentially built on the principle of montage: it achieves its desired expression by juxtaposing impressions that are distantly alien to each other. For this is the psychological basis of the montage technique: to record interconnections that transcend those in the outside world but remain possible in our inner world, to transform transitory associations of ideas into a lasting picture!"266 These lines lead us to the question of what it was about the fresco in Budaörs Airport that made it truly exceptional, apart from its technique. The answer clearly lies in the trinity of demands: a cinematographic portrayal of surrealistic experiences, dynamic imagery, and memorylike evocations. "This was the task that we gave to our accomplished photographer, Mrs Elemér Marsovszky, who bore sharp witness to her understanding of our intentions during the course of the extensive preliminary discussions." 267 It speaks volumes that the architect remained actively involved in the execution of the montage from the beginning to the end, in formulating

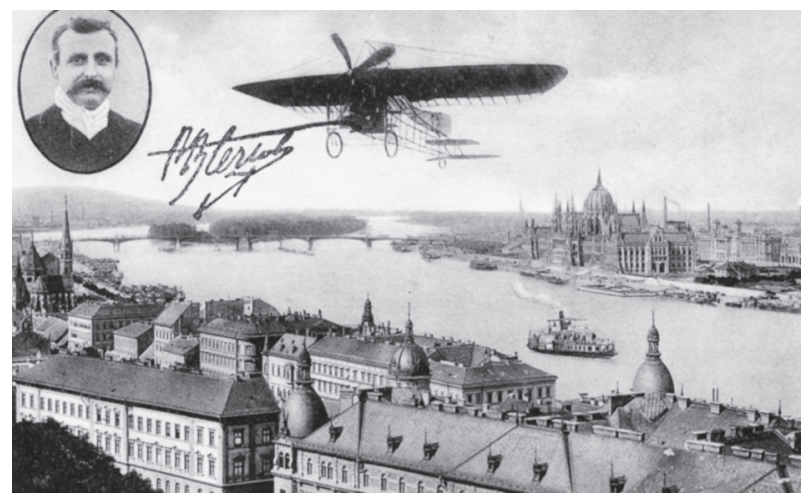

Fig. 82. Postcard with the panorama of Budapest, produced around Louis Blériot's flight in 1909 (private collection)

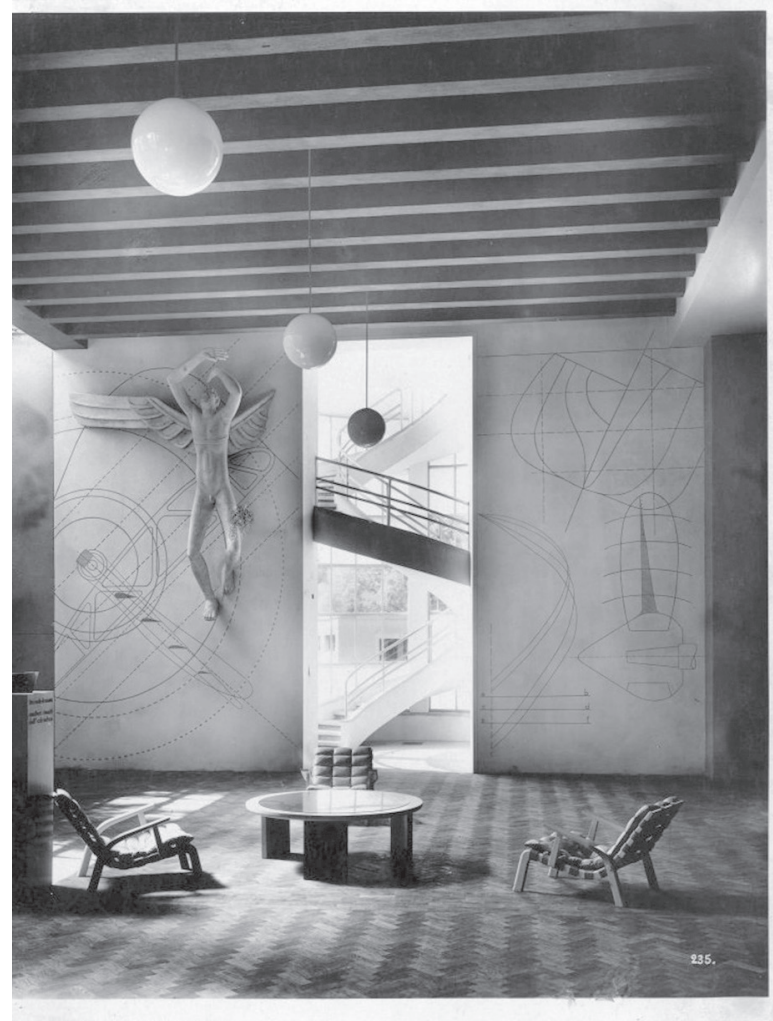

$V$
$V$

Fig. 83. The Fifth Milan Triennale, 1933, lobby with Prometheus's figure and modern furniture in the foreground (IPM FLT 23.025)

the concept, in obtaining the aerial photographs, and in directing the work. ${ }^{268}$

Bierbauer traced the roots of montage not only to modern film but also to Expressionism and Surrealism; the most important period in his view was the 1920s, when artists began to explore new ways of using photography both in Paris and at the Bauhaus in Weimar. "Some 10 or 15 years ago, out of the eternal thirst for mural painting and photographic methods of depiction was born a new compositional process, 
which today is beginning to mature, to grow into art: this is the photographic fresco." ${ }^{269}$ An important stage along the road leading from the naturalistic portrayal of reality towards abstract thought was the examination of how photographs could be conceived of as a set of pictorial elements that could be cut out, blown up and reassembled into a different, completely autonomous composition. Avant-garde artists were the first to experiment with the montage technique, which would form the theoretical and technical basis of the composition in Budaörs Airport, and this led to the creation of a new way of decoration walls. Bierbauer probably had in mind the exhibition in Rome (1932), where he first witnessed the monumental impact of photomontages covering entire walls. At the "Mostra della Rivoluzione Fascista" in the Palazzo delle Esposizioni in Rome, 2000 square metres of wall surfaces were covered with photomontages and photographic reproductions. ${ }^{270}$ While Bierbauer had several reasons for regarding Italian exhibition design as a model worth copying, he also expressed a few thoughts on the tense differences of opinion between modern architecture and the fine arts. In his afore-mentioned article On the Photofresco, ${ }^{271}$ he refers, albeit briefly, to the notorious "fresco debate" at the Volta conference, where the conservative Ojetti and the curator of the fascist exhibition, Marinetti, exchanged heated words after Ojetti described the photofrescos as ephemeral posters. He also mentions the "Photomontage" exhibition at the Kunstgewerbemuseum in Berlin, which not only featured Moholy-Nagy's enormous photographic composition Berlin, but also works by Raoul Hausmann, Hannah Höch, Jan Tschichold, Karel Teige, El Lissitzky, Gustav Klutsis and Alexander Rodchenko. In the same year (1931), Hausmann, a member of the Dada group in Berlin, published his history of the montage (also mentioned above), titled Photomontage. ${ }^{272}$

All these considerations during the planning stage of the airport culminated in the idea of the photofresco. In the iconographic programme associated with the genre there were several opportunities for depicting aircraft and for showing details of panoramas and landscapes in various combinations. Bierbauer was of the opinion that naturalist, painted forms of art were unable to convey the optical experience of flight, so the final decision was for a fresco-like photomontage composed from aerial photographs ${ }^{273}$ (Figs. 84-88).

Besides its artistic opportunities, this technique was also ideal for the shape of the work's designated surface, because it provided the artist with ample room for manoeuvre when it came to arranging the visual

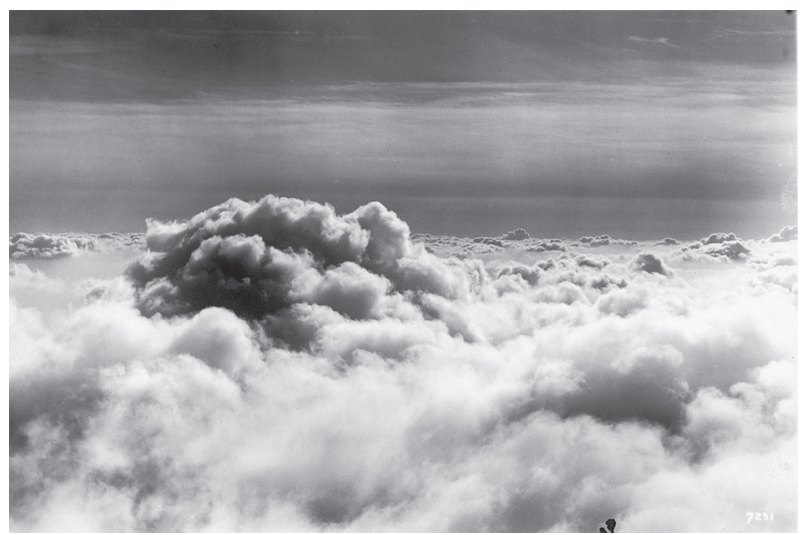

Fig. 84. Cloud picture, 1920s-1930s, from the aerial photographs collected by Virgil Bierbauer for the cyclorama (MÉM Borbíró-hagyaték GYN: 659)

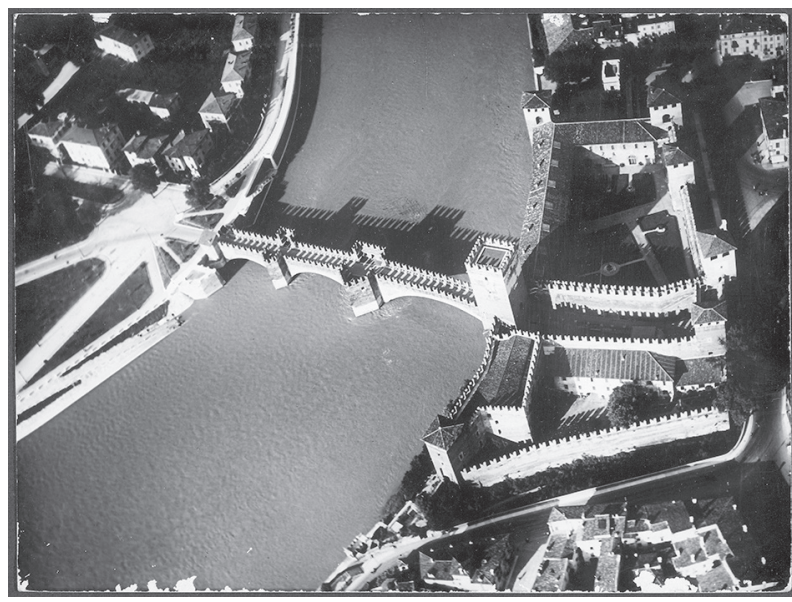

Fig. 85. Aerial photo of Ponte Scaligero (Ponte di Castel Vecchio) over the river Adige and the Castelvecchio in Verona, related to the part between sections II and III of the cyclorama, from the aerial photographs collected by Virgil Bierbauer for the cyclorama from abroad (MÉM Borbíró-hagyaték GYN: 659)

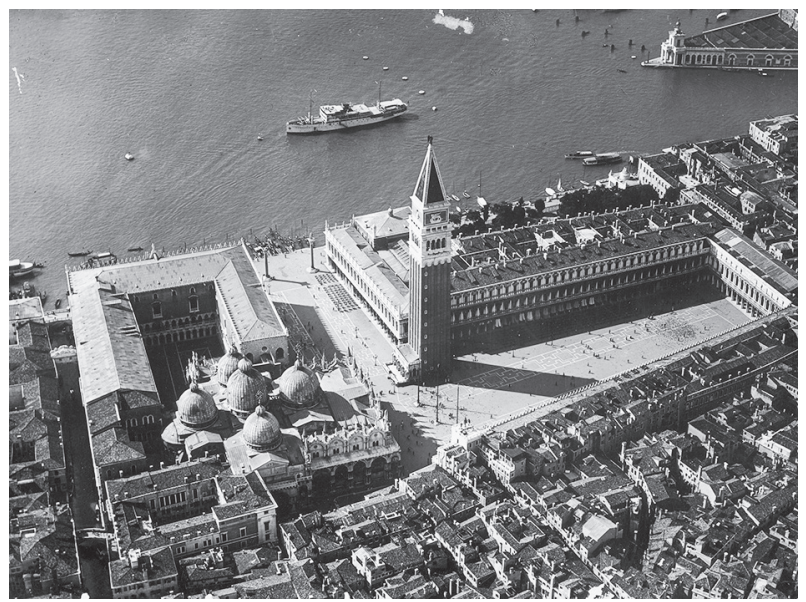

Fig. 86. Aerial photo of Saint Mark's square in Venice, related to the section IX of the cyclorama, 1930s, from the aerial photographs collected by Virgil Bierbauer for the cyclorama from abroad (MÉM Borbíró-hagyaték GYN: 659) 
elements. The continuous and uninterrupted composition covering the long, low balustrade of the waiting room in Budaörs Airport had to harmonise with the cool, subdued colour scheme of the interior. ${ }^{274}$

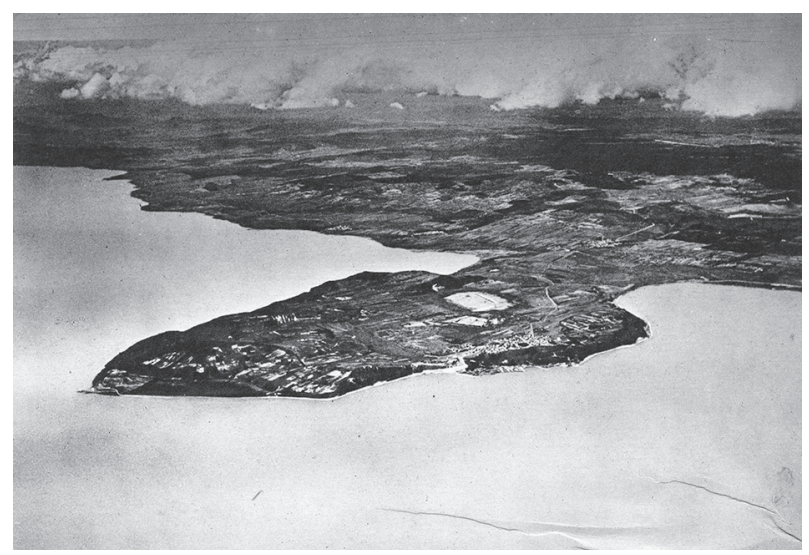

Fig. 87. Aerial photo of the Tihany peninsula at Lake Balaton, related to the section VII of the cyclorama, from the aerial photographs collected by Virgil Bierbauer for the cyclorama (MÉM Borbíró-hagyaték GYN: 659; published in BiERBAUER 1937D. Fig. 3)

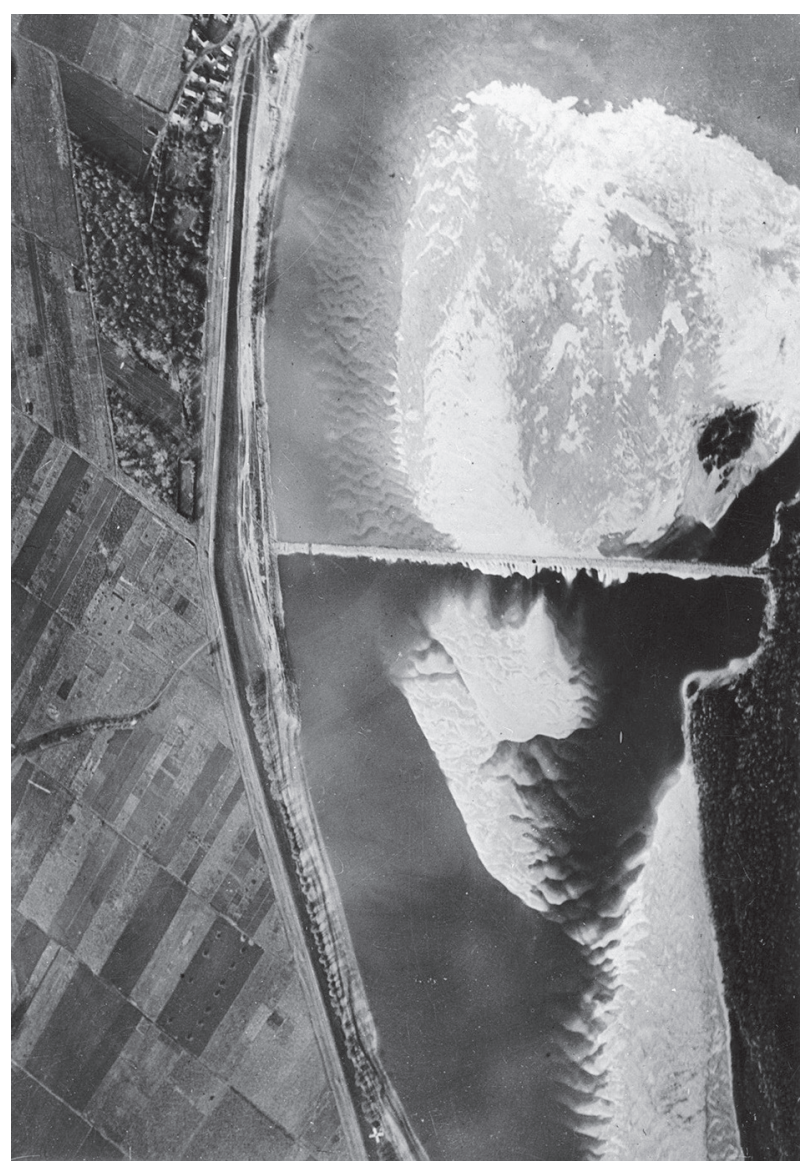

Fig. 88. Aerial photograph related to the section XII of the cyclorama, from the aerial photographs collected by Virgil Bierbauer for the cyclorama (MÉM Borbíró-hagyaték GYN. 659)

\subsection{Preparatory stages of "The Experience of Flight"}

The first task in preparing the photomontage was to make the drawn sketches (stage 1) based on the designers' instructions, after which the photographer reproduced the selected aerial images (stage 2). Next, she began to produce the enlargements from the duplicate negatives (Fig. 89), and could then assemble the maquette of the entire work on a scale of $1: 10$ (stage 3). Similarly to sketches by architects and fresco painters, this was presumably the basis on which the final concept was approved. Bierbauer wrote about this part of the process, "Of course there were some details that demanded a whole series of changes and amendments before the combined patchwork effect became fully satisfactory, and before a certain internal and formal logic fell into place at the crossover points."275 Using the photographic maquettes, Mrs Marsovszky subsequently prepared the seventy photographic reproductions (stage 4) that would be used as the final enlargements. ${ }^{276}$ In the last part of the process, the 1:1 scale blow-ups, or "sheets" - of which there were seventy in all - were glued together (stage 5), laminated (stage 6) and retouched (stage 7), before being affixed to the balustrade wall using a special adhesive (stage 8). After the cyclorama was fully in place, the places where the sheets joined were rechecked, and if any tonal differences were observed, they were covered over using a spray-on retouching technique (stage 9). It is possible that the entire cyclorama was then also treated with some kind of protective coating, but there are no data about this. One interesting detail about the work process is that the enlargements themselves are shaped in accordance with the inside cylindrical (more precisely conical) form of the balustrade wall, which had been designed and built at a slight angle, taking account of the fact that the work would be viewed from below. This was the only way of approximating a face-on view of the images. The intricacies of the photographer's work are described in an excerpt that reads, "The natural consequence of this was that certain photographic sheets had to be enlarged in the shape of a trapeze, otherwise they would not have matched up, which could not be permitted, for the images of some buildings, for example, span from one sheet over to the next. This makes one appreciate the meticulously precise work the photographer had to perform."277 In our analysis of the cyclorama we shall see that Mrs Marsovszky alternated between her use of pictures with a perfect overhead perspective, when the viewed plane was completely perpendicular to the 


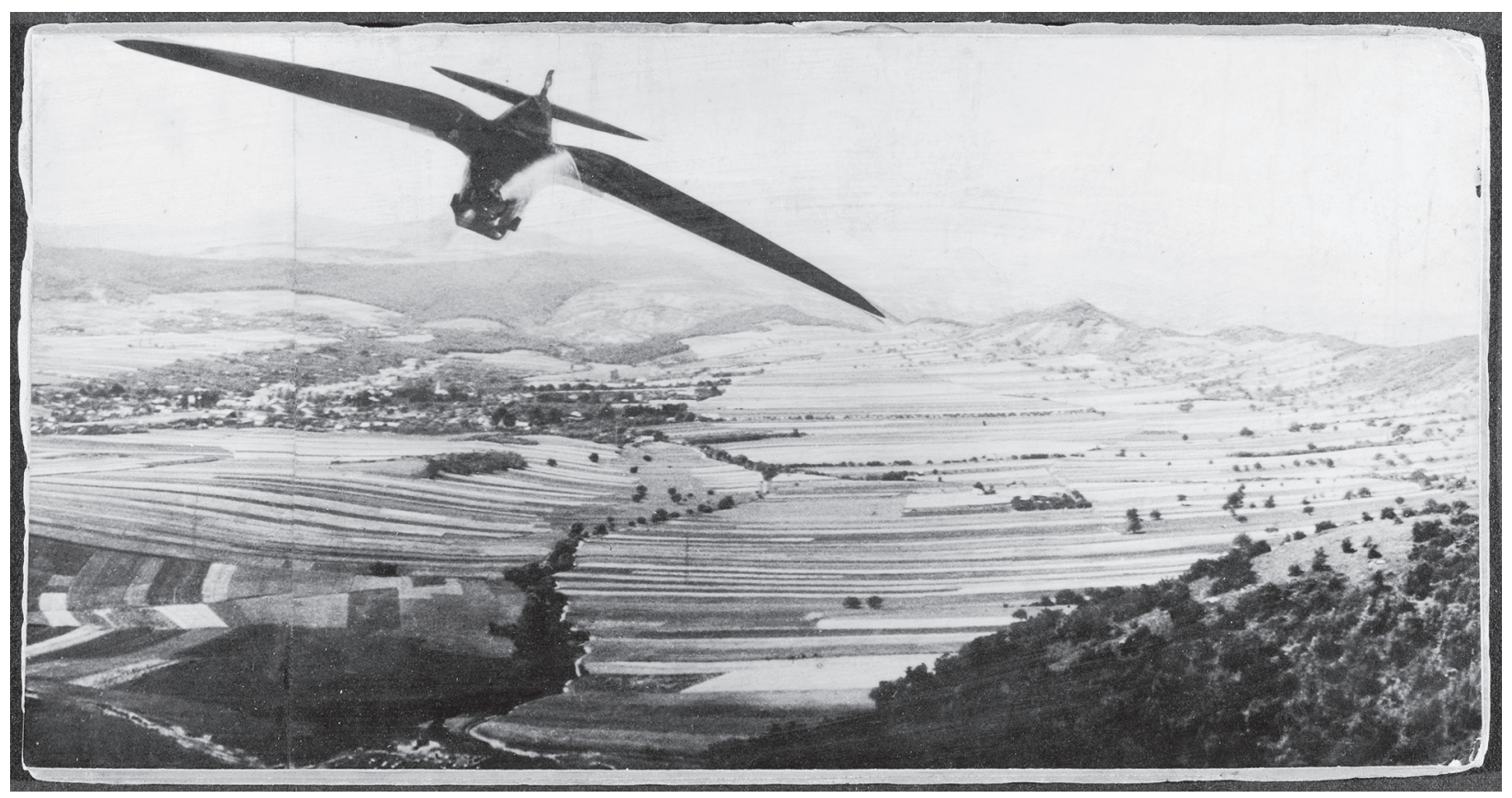

Fig. 89. One of the original models of the cyclorama, photo stuck onto a cardboard by Mrs Elemér Marsovszky, 1937 (MÉM Borbíró-hagyaték GYN: 659)

line of sight, and those taken at an angle. We assume that the reason for this was not only to enhance the dynamism of the spectacle, but also because, for the benefit of the viewers standing on the ground floor, it was not enough to tilt the balustrade wall, for the overall effect of using only two-dimensional photographs would have been visually disturbing.

Among the writings of Virgil Bierbauer pertaining to the cyclorama, passages that can be interpreted as summaries of the completed work are particularly enlightening: "The technical process is appropriate for numerous reasons. It is suitable in terms of style, firstly because it is in line with modern forms of vision, which have moved far beyond naturalism, and secondly because, by virtue of its surrealistic nature, it can never generate the uncomfortable feeling that we are looking past the mural at what is on the other side of the wall. This surrealistic picture is autonomous in itself, and the image plane of the entire work seems to float in front of the wall, becoming transubstantiated as its material nature fades away. Photograph and paper become mere conveyors of spiritual content and imagination."278 Finally, Bierbauer highlighted the collective character of this montage, which not only synthesised hundreds of photos, but also the personal choices and visions of the different people who had taken them.

We have already mentioned that the most essential element of the work's content, in the minds of its creators, lay in the ability of the photomontage to transcend conventional means of depiction. The cyclorama was clearly intended to immortalise a vision of the evanescent experience of flying that was caught up in the flowing currents of time and space. The required effect was more akin to a film than to a still image. This is where the technique of montage came into its own, because of the creative freedom and flexibility it offered in terms of arranging and rearranging the imagery. It was essential therefore, not only to pay attention to the size of the balustrade $(105 \mathrm{~cm}$ high and 44 metres in circumference), but also to calculate the proportions precisely, in order to avoid potential distortions. In his study on airport architecture, Bierbauer wrote that the unity of the balustrade's "continuous circular surface" could only be preserved using the photomontage technique. ${ }^{279}$

Numerous parts of the planning and implementation stages, such as the use of maquettes that take the architectural features of the space into consideration, resembled those employed when frescos are painted. Spherical triangles, arches and domes inside buildings can also be painted in a distorted manner so that the end result, as seen by viewers from the ground, gives an illusion of true proportions.

Bierbauer's explanation of the message behind the cyclorama also brings us closer to understanding the work as a whole: "The basic concept was for the composition, consisting of 200-250 aerial photos, 
to express, with a more-than-naturalistic, one might even say surrealistic vision, the miraculous optical and mental experience of flying. To put it another way, the photo-frieze was expected to evoke the remembered image of a fantastic trip by airplane forming in our minds as a sequence of flashbacks." 280 Besides the principles of montage, the artistic devices of Surrealism, with its method and concept of imagery, were best suited to portraying the external (optical) and internal (mental) dimensions of flying. From Bierbauer's words we can deduce that the central elements of the concept were motion and surrealistic vision. His support for a surrealistic montage portraying a journey both internal and external illustrates the increasing interest that modern-thinking people were taking in psychoanalysis and the subconscious mind. The mixed Hungarian reaction to this unusual cyclorama can be attributed to the fact that the general public was so accustomed to naturalistic painting that their instinct, when faced with a composition that its designer described as surrealistic, was to protest that they could find no order in the work, nothing to give them a foothold. How did the architect handle this situation? As he put it, "I strove to explain that the order in the picture came not from nature but from the psyche"281 (Fig. 90).

One important source for the artistic background to the airport photomontage can be found in contemporary texts dealing with the changes in the approach and vision of photography. Photoplastics and photomontage were similar in that both were made by assembling images from different photographs onto a single plane. In 1928 Moholy-Nagy wrote the following about the role of time in photoplastics: "Like photomontage, photosculpture [photoplastics] is made up from different photographs that are pasted together, retouched, and compressed in one plane. But photosculpture tries to remain moderate in its presentation of simultaneity. [...] It shows situations in a compressed state which can be unwound very quickly by the process of association. This economical method makes understanding easier and often suddenly reveals an otherwise hidden meaning."282 Details were

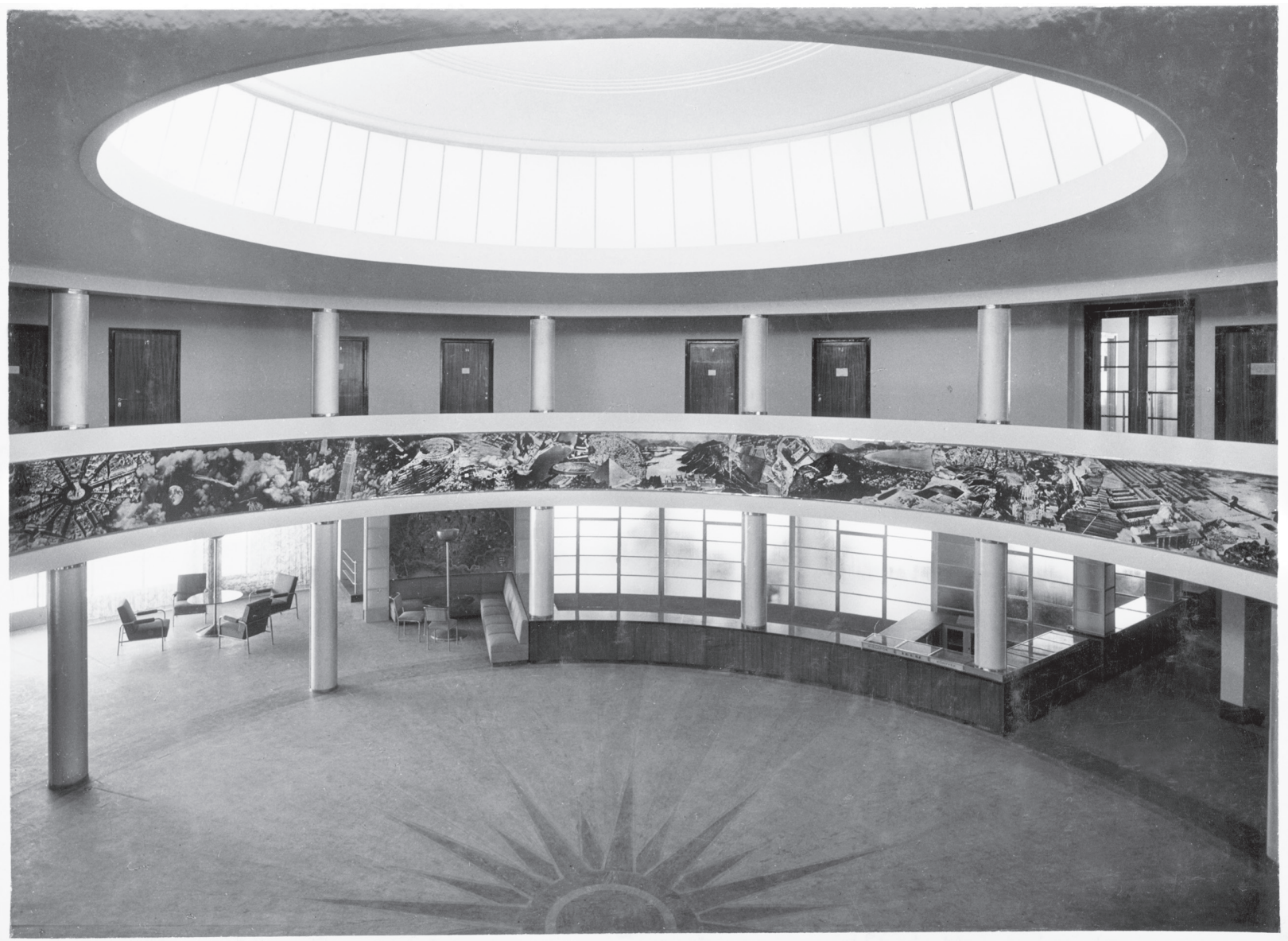

Fig. 90. The waiting room of Budaörs Airport's terminal building, from left to right with the sections I-II-III-IV-V of the cyclorama towards the runway (photo: Mrs Elemér Marsovszky, Belvárosi Fotómúhely, 1937; MÉM Borbíró-hagyaték GYN: 659. 21. doboz) 
usually joined together with lines, creating unexpected connections and tension within the image. The artistic function of photoplastics lay in its capacity for synthesising and compressing all the mental and visual elements captured in a single moment. Despite this compression, the photoplastics, as conceived by MoholyNagy, have a central meaning as well as a visual centre, both of which are easy to identify. In his descriptions, he refers to the concepts of photomontage and photoplastics as analogues of each other, which also shows how similar they are. ${ }^{283}$ The differences are mostly to be found in the techniques for making them. The other device that revolutionised typography was the "typophoto," which essentially consisted of "phototexts," that is objective illustrations with clear meanings, placed beside words or instead of words. ${ }^{284}$ Of the visual languages listed above, the "typophoto" bore the most specific meanings, followed by photoplastics, which had a broader framework of interpretation, and finally, the least specific was the photomontage.

From a historical point of view, however, the principle of photomontage dates back to the period preceding Futurism, in particular to group photographs and pictures of important events originating from the nineteenth century and the early 1900s. What they did in those days, essentially, was to paste or copy a group of images, taken separately, onto the same background, retouching any seams so that nobody would notice that it was not a snapshot of one single moment. This was how the first photomontages were made. Photoplastics, by contrast, were compared with the stream of visual stimuli that inhabitants of big cities were constantly bombarded with, ${ }^{285}$ symptomatic of the modern notion of how time and space were experienced by people in motion.

\subsection{Pictorial sources of the photomontage, identifying the locations}

At the end of 1936, work was begun on collecting together the aerial photographs, which lasted until some time in spring the following year. In one of the maquette photographs that have survived from the planning stage, Mrs Borbíró also dated the cyclorama to the same time. An article written after the airport was officially opened mentions the following sources for the photomontage: "Mrs Elemér Marsovszky, who implemented the ideas of the designers in close cooperation with them, was facilitated in her options for compiling the photo-frieze, or if you prefer, photo-

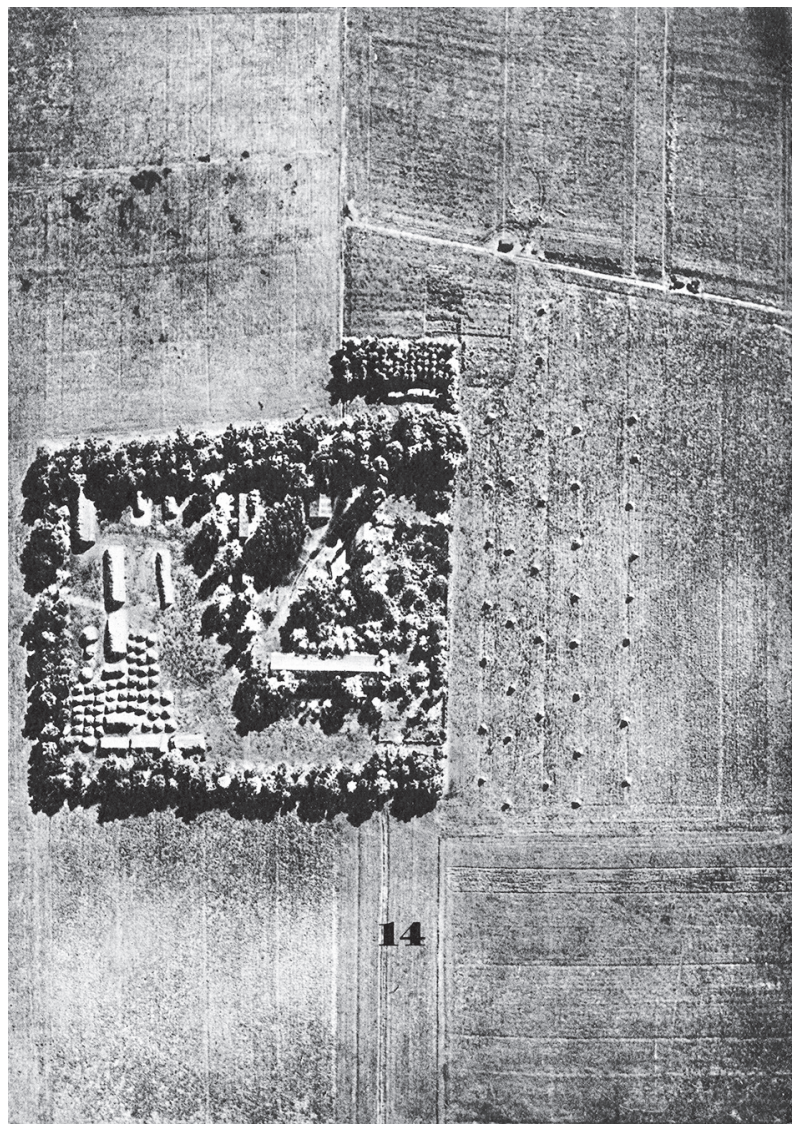

Fig. 91. Aerial photograph of the Hungarian settlement Csorvás (published in Bierbauer 1937D. Fig. 12)

fresco, by the original aerial photographs made available to her by the Hungarian Royal Institute of Cartography, Royal Dutch Airlines (KLM), the Österreichische Luftfahrtgesellschaft (ÖLAG), the Italian Tourist Board (ENIT), the Reichsbahnzentrale für den Deutschen Reiseverkehr, and the Zeppelin Works." 286 The only document I could find pertaining to how the photos were procured is a receipt, dated 24 April 1937, listing the identification numbers of 50 aerial photographs borrowed from the Institute of Cartography. It was stipulated, among other things, that the photographs could not be used for any other purpose, and that any duplicate negatives produced from the aerial photographs would have to be returned to the institute after completion of the work. In order to ensure that further copies could not be produced, the user was obliged to destroy all working copies and auxiliary materials. ${ }^{287}$ This probably explains why the Borbíró estate has no photographs bearing the stamp of the Hungarian Royal Institute of Cartography. However, some of the blackand-white, $13 \times 18 \mathrm{~cm}$ photographs from the foreign collections have survived; most of these were enlarged and used in the cyclorama. Another important source 
is the book published by Bierbauer titled Hungary from an Aeroplane (Magyarország repülógéprôl), ${ }^{288}$ which is illustrated with 27 aerial photographs (Figs. 87, 91-97).

Some of the photos in Bierbauer's book were also used in the cyclorama (Figs. 93/104, 94/110, 95/110, 97/98), including one of the finest pictures in the montage, the aerial view of the Hungarian town of Hajdúböszörmény (Figs. 96/99) which was also pointed out by Lajos Kozma (but the name was written in the article by mistake as Hódmezôvásárhely). ${ }^{289}$ The aim of the book was to show the peculiarities of the Hungarian landscape and the shapes of its settlements. There was no lack of notable buildings either, which were shown from a lower height, as so-called "scenic photographs." The designers summarised the results of the work as follows: "... with the photomontage it became possible to create a continuous composition, in a cohesive artistic sense, and furthermore by adding a hint of colour to the photo-frieze we managed to achieve the cool shade that best suits the space as a whole. On top

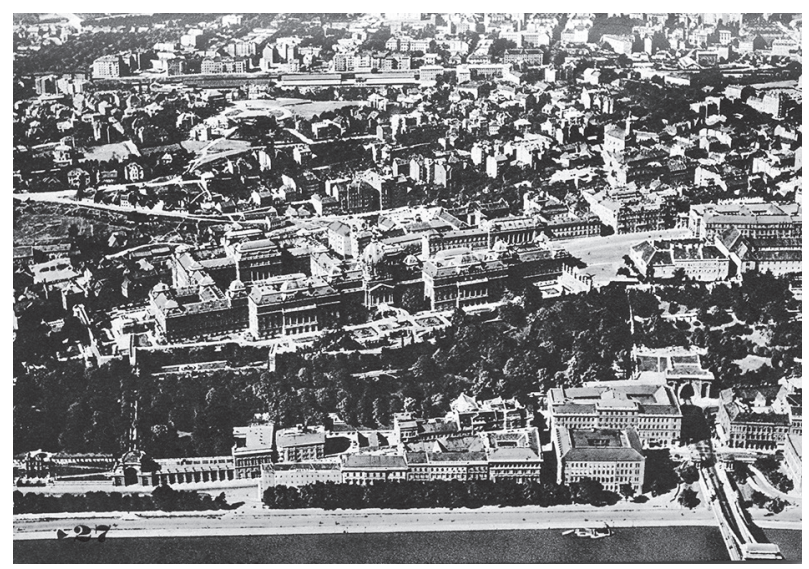

Fig. 92. Aerial view with the Royal Castle in Buda

(Budapest), related to the section VII of the cyclorama (published in BierbaUer 1937D. Fig. 27)

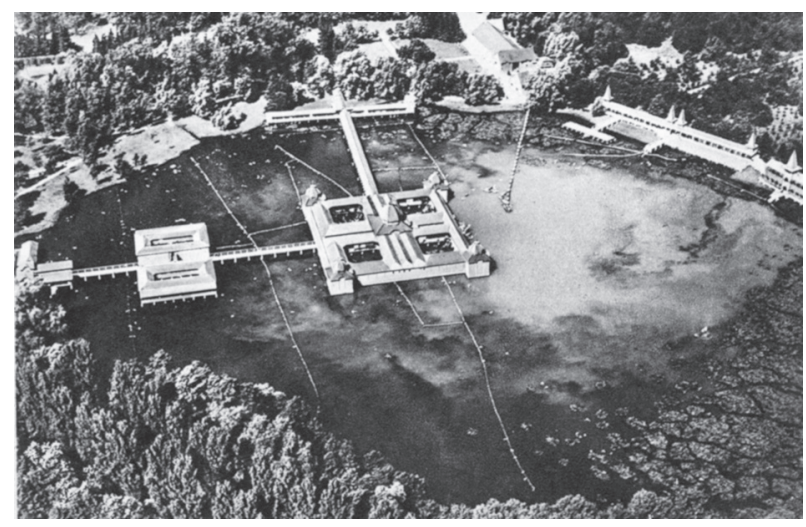

Fig. 93. Aerial photograph of the Hungarian settlement of Hévíz, related to the section II of the cyclorama (published in Bierbauer 1937D. Fig. 6) of all that, we made a kind of decorative picture which, by dint of its theme, complied closely with the function of the building. We tailored the depiction to its subject: to evoke the experience of flight."290

The photographs Mrs Marsovszky took of the inside of the airport in 1937 are the best source we have for reconstructing the original appearance of the waiting room; a large number of $13 \times 18$-centimetre vintage copies still survive. ${ }^{291}$ The next important series of photos was taken by Béla Hollenzer in 19451948 , and it includes pictures of the interior that also show some of the technical staff who worked there. ${ }^{292}$ His images of the waiting room, however, only show the cyclorama from a distance, as a monumental and decorative element of the entire space. For the details, there is no better basis than the images published in Tér és Forma (Fig. 100).293 The only problem posed by these prints is that they can only be magnified to

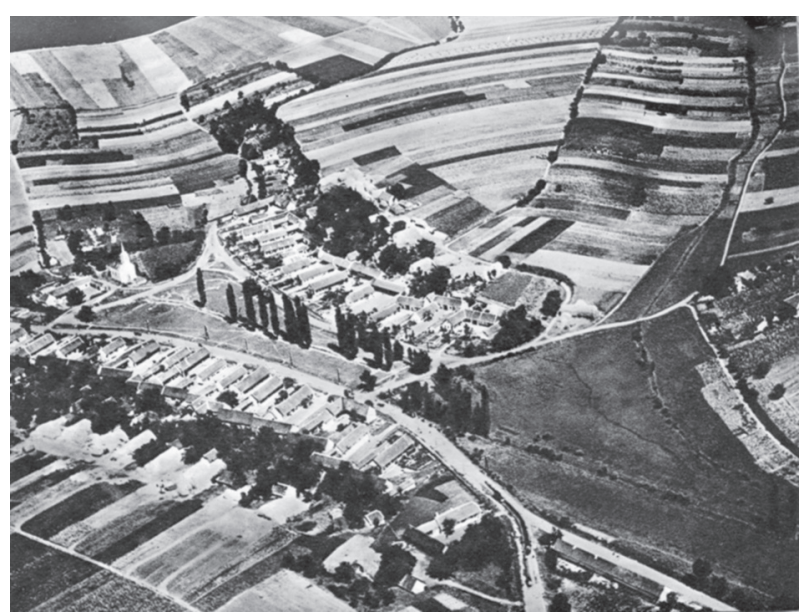

Fig. 94. Aerial photograph of a Hungarian village, related to the section XII of the cyclorama (published in Bierbauer 1937D. Fig. 17)

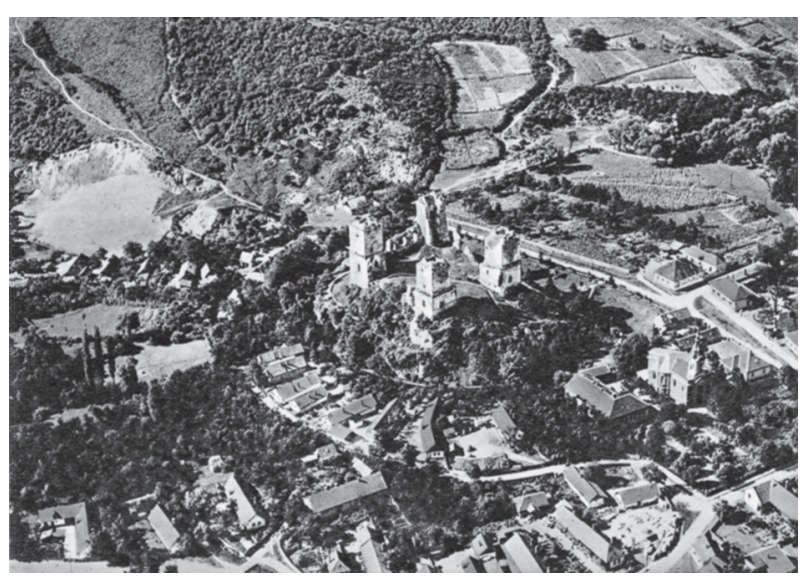

Fig. 95. Aerial photograph of the castle of Diósgyôr, related to the section XII of the cyclorama (published in Bierbauer 1937D. Fig. 12) 
a certain extent, meaning that not every detail of the cyclorama is perfectly clear.

In making my description I have not attempted to identify every single detail of the photomontage, concentrating instead on trying to uncover the dramaturgical methodology by which the photographer selected from over a hundred pictures and decided how to place them together. To the best of my knowledge, apart from some tiny comments, there are no texts, documents or instructions annotating either the entire cyclorama or any of its components, so my efforts to analyse the iconographic content of the mass of images constituting the work have had to rely on the available photographs. There are only three contemporary texts that identify or describe any of the places seen in the cyclorama. Two of them are picture captions "From the photofresco in Budaörs Airport: New York - Rome - Hévíz - Szeged. Photo: Mrs Elemér Marsovszky" (Fig. 100: first picture from above) and "From the photofresco in the Budaörs Airport building: Siófok - Schönbrunn - Venice - Tihany. Photo: Mrs Elemér Marsovszky"294 (Fig. 100: fourth picture from above) - while the third is a slightly longer description in the review of the work written by the architect Lajos Kozma: "In this panorama, with its strangely condensed ether, an Egyptian pyramid is paired with the Arc De Triomphe in Paris, the giant, crater-like ring of the Colosseum in Rome with the reinforced concrete geyser of an American skyscraper, and the chaotic, unpopulated barrenness of some alpine scenery with an enormous cityscape, whose neatly organised beauty and human-hive geometry are interestingly counterpoised by the amorphousness of the mountains (I was later informed that this wonderful cityscape shows the enormous village of Hódmezôvásárhely ${ }^{295}$ ). The photomontage was composed by Mrs Marsovszky under the direction of Dr Bierbauer."296

\subsection{The iconography and a section-by-section description of the cyclorama}

The photomontage is centrally located above the middle of the room, occupying a 360-degree circle, and is titled "The Experience of Flight" ("A repülés élménye"). It was made in 1937 by Mrs Elemér Marsovszky. ${ }^{297}$ The medium is black-and-white photomontage. It measured $105-125 \mathrm{~cm}$ in height, and had a total length of 40-44 metres. (Bierbauer sometimes mentions 40 metres, ${ }^{298}$ sometimes 44 metres, ${ }^{299}$ although Lajos Kozma was far wide of the mark in estimating its length at around 80 metres. ${ }^{300}$ ) Several terms are used to describe the genre of the work: cyclorama, because of the shape of the balustrade; mural, fresco and photofresco, because of its function; and photomontage, because of its technique.

When putting together the frieze-like and extremely long circular picture, the photographer paid attention to the fundamental requirements of her client. Bierbauer, who also took an active part in the planning process, explained several times what was expected of the photographer: "The task therefore was for the picture to conjure up the kinds of associations of imagination and memory that fill our minds when we remember our journeys by air. At such times, picture after picture fleets past our inner eyes, not in any true sequence, of course, nor in accordance with their true connections, but in a mesmerising succession: flashes of memory suddenly blurring into each other, whirling around in the dynamic maelstrom of the soul." ${ }^{301}$ One of the most intriguing questions concerns the opportunities for representing such an imaginary journey using the tools of photography. In terms of dramaturgy, the horizontal flow of the photomontage was built around a rhythm of perspectival and orthogonal photographs. The artist had several means at her disposal for generating a sense of motion. One was an undulating arrangement of the pictorial elements, which meant in practice that details of images showing hills or mountains, towns, fields, lakes and watercourses were interrupted at regular intervals by buildings or other prominent landmarks. The other way of breaking the static nature of the cyclorama was to combine different types of aerial photographs, basically alternating pictures having a perpendicular axis (orthogonal or planar pictures) with those taken from an angle (perspectival pictures). Planar landscapes generally served as connecting elements, although there are examples of planar, map-like urban details occasionally playing the lead role in certain places, if they had particularly interesting or beautiful layouts. The spatial characteristics of the waiting room also influenced the arrangement, because instead of the more customary situation in photomontages, whereby the elements are grouped around a focal point, inside the terminal building the different parts had to be stretched out around the balustrade. As montage facilitated artistic flexibility and freedom, this was not an insurmountable issue when it came to rearranging the different parts of a cityscape. In the case of Buda Castle, the artist placed it almost opposite the viewer, which distorted the lay of the river Danube, although 


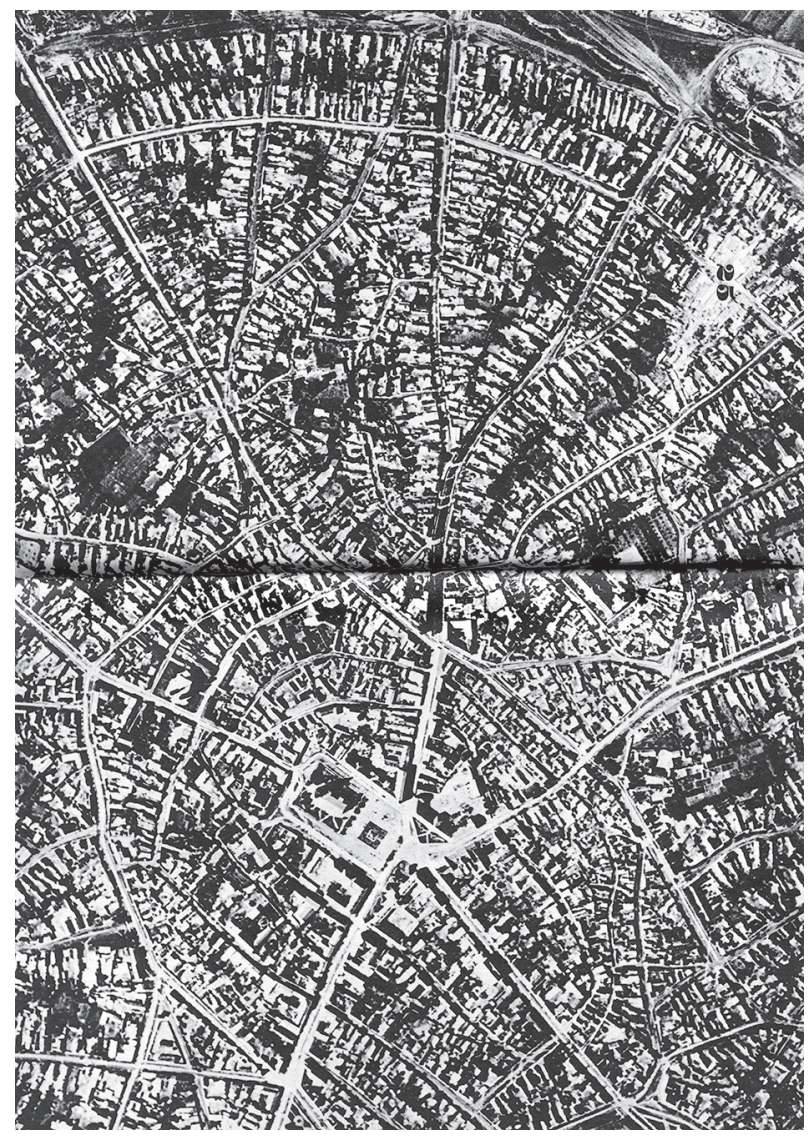

Fig. 96. Aerial photograph of the Hungarian settlement of Hajdúböszörmény, related to the section III of the cyclorama (published in BierbaUer 1937D. Fig. 25)

this could hardly be considered a problem in view of the fact that the ultimate aim of the work was to generate surrealistic effects.

Simply putting together pictures of different landscape types and buildings (farmlands, coastal areas, mountain ridges, built-up areas and monuments) would not have resulted in anything particularly spectacular; grouping them in novel associations, connecting them rhythmically and splicing them together with verve and creativity, however, transformed the photomontage into a truly captivating work of art. The separate details were linked by cloud motifs, which not only helped to cover over the joins but also underlined the dimension in which the whole narrative was played out. Unlike in works of aeropittura, the photomontage featured no travellers, no pilots, and not even a separate cockpit view. Nevertheless, there was no shortage of aircraft structures and indeed whole aeroplanes in the cycle of pictures, and to these images were added rings, spirals and ellipses, geometric forms alluding to the rotational motion so fundamental to aviation.

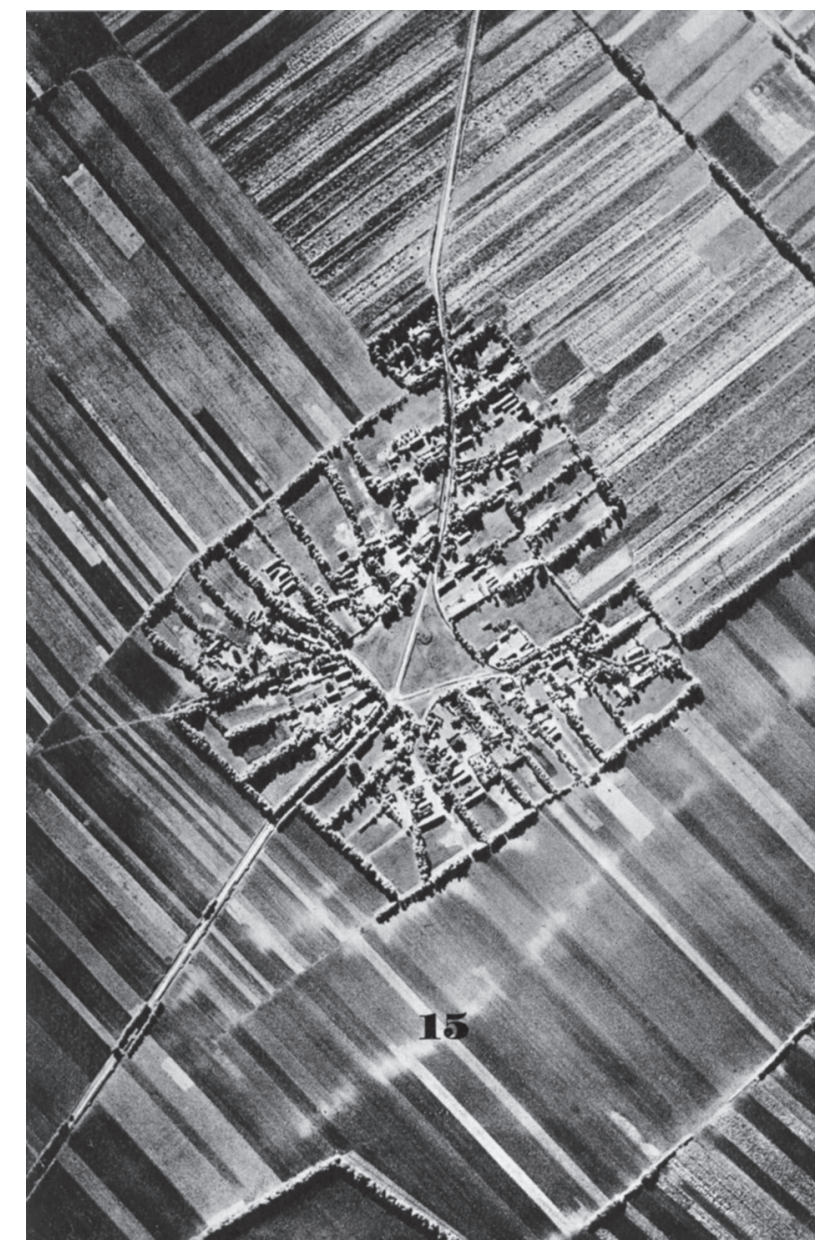

Fig. 97. Aerial photograph of an agricultural landscape in the vicinity of the Hungarian town of Nyíregyháza, related to the section VI of the cyclorama

(published in Bierbauer 1937D. Fig. 15)

The common understanding of aeroplanes as symbols of power is revealed by the fact that after the Second World War, when the Hungarian-Soviet Airline (MASZOVLET; Fig. 101) was founded (1946), the aeroplanes visible in the photomontage were repainted in Russian insignia. This represented the secondary iconographic recomposition of the pictures. Two important details of the unified composition deserve a mention here, because they were repainted and restructured first after the communist seizure of power. Contemporary photographs show that the montage came together in the middle of the section of the balustrade facing out towards the runway. At this point, the left and right sides of the frieze were connected by an image of the moon surrounded by fluffy clouds, flanked by iconic images on both the left (a New York skyscraper) and the right (Arc de Triomphe, Paris). The central band, where the clouds used to be, now shows Red Square in Moscow, with rays 


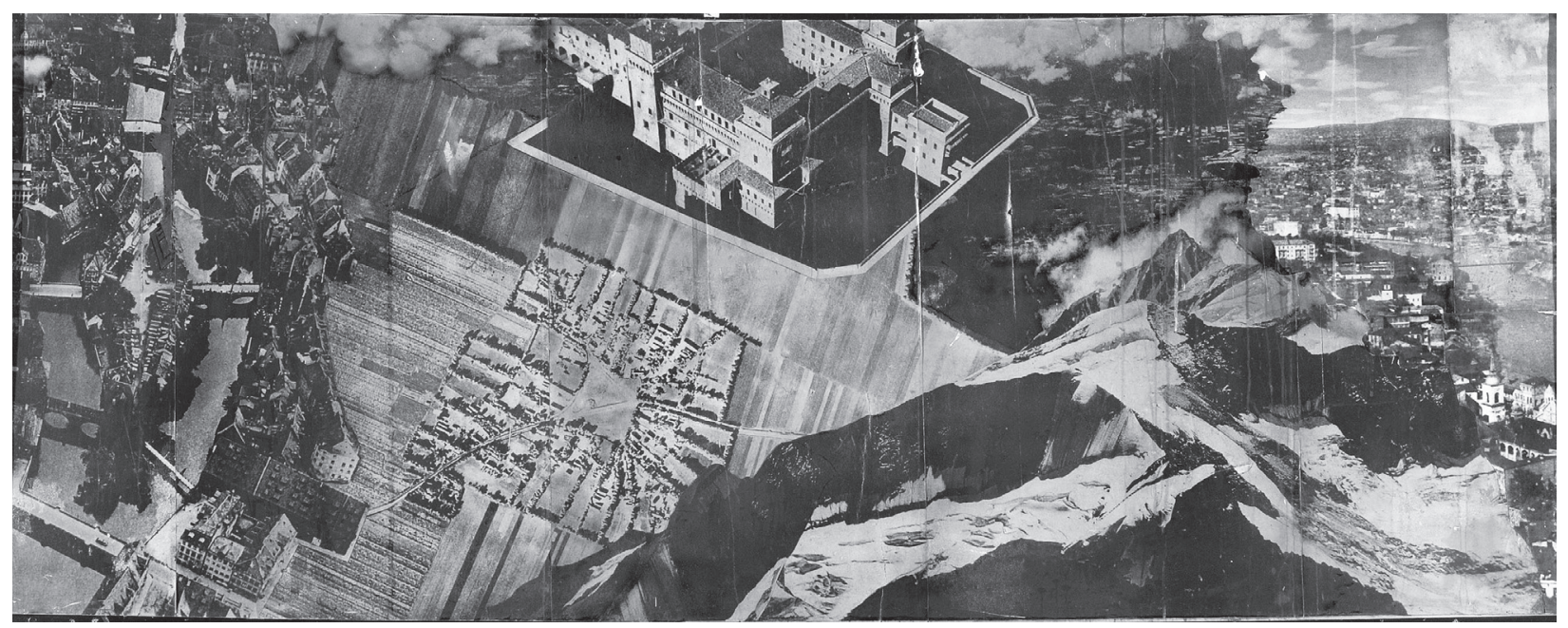

Fig. 98. Cyclorama detail (section VI) with a view of an agricultural landscape in the vicinity of the Hungarian town of Nyíregyháza (photo: András Ágh, 2006)

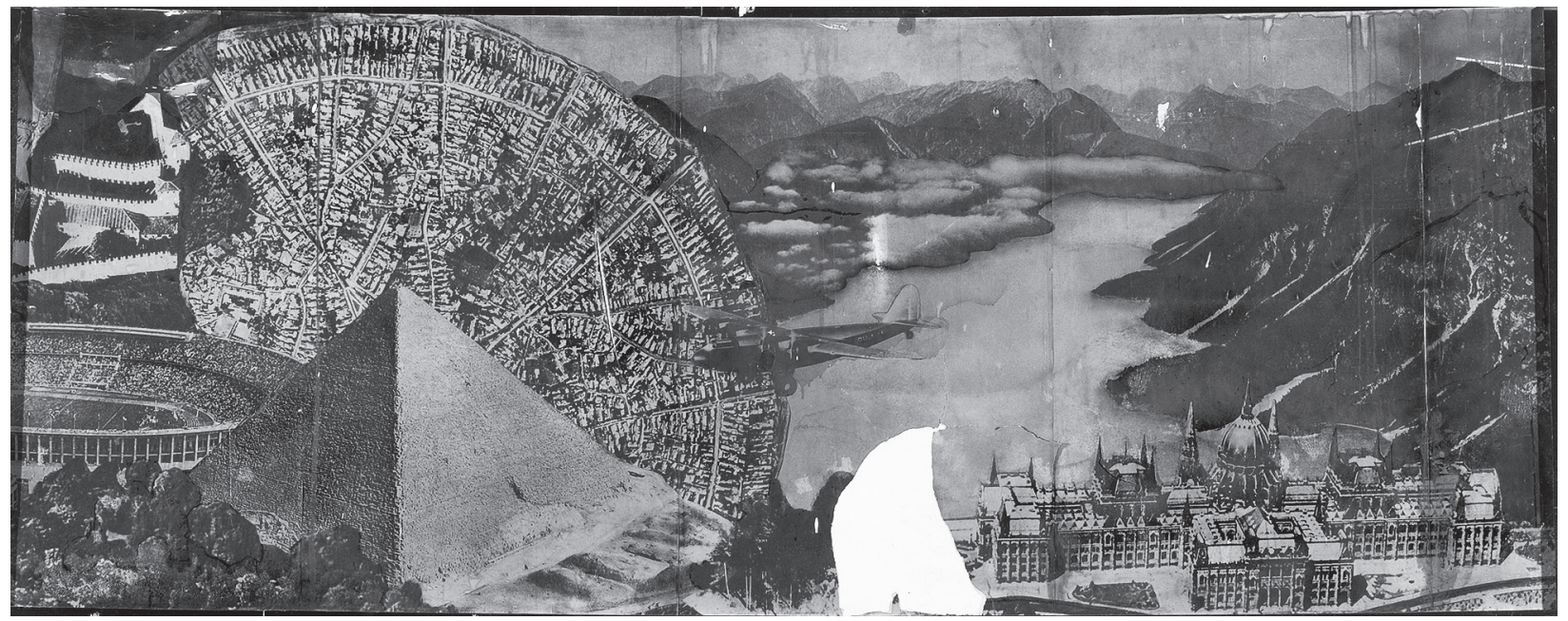

Fig. 99. Cyclorama detail (section III) with a view of Hajdúböszörmény (photo: András Ágh, 2006)

of light beaming down on its buildings. The cyclorama had two distinct "centres," with one being the afore-mentioned runway-side view, while the other, showing a landscape dominated by the Two Towers of Bologna and Buda Castle, was above the waiting room entrance. This detail is now also in a form different from its original status.

When the cyclorama was broken up, the photographic composition fell apart, forming separate sections, so it is now difficult to determine all the different layers of the photomontage. During the Second World War, the airport terminal building did not suffer significant damage (Fig. 102), so the cyclorama also survived more or less intact. In the photographs taken between 1945 and 1948 by Béla Hollenzer, ${ }^{302}$ medium-sized patches can be seen in the top third of some of the pictures, and the work had not yet been repainted at all. The next few images come from the 1970s, and they clearly show traces of water damage and the alterations carried out on the section of the cyclorama on the runway-facing side of the building. The photomontage suffered the most severe damage during reconstruction work undertaken in 1986 to reinforce the waiting room ceiling by shoring it up with stronger columns. This resulted in the cyclorama being cut into sections (Figs. 74, 98-99, 103-110, 122, 124-126). One eye-witness recalled that the leftover pieces were simply thrown away. There are twelve sections on the balustrade today, with empty gaps in between them.

Besides its nature as a montage, the world of the cyclorama was characterised by the axonometric method of depiction - without a central perspective deriving from its aerial perspective. Between the wars, modern architects resorted to using the bird's eye perspective. One of the advantages of drawings floating in 

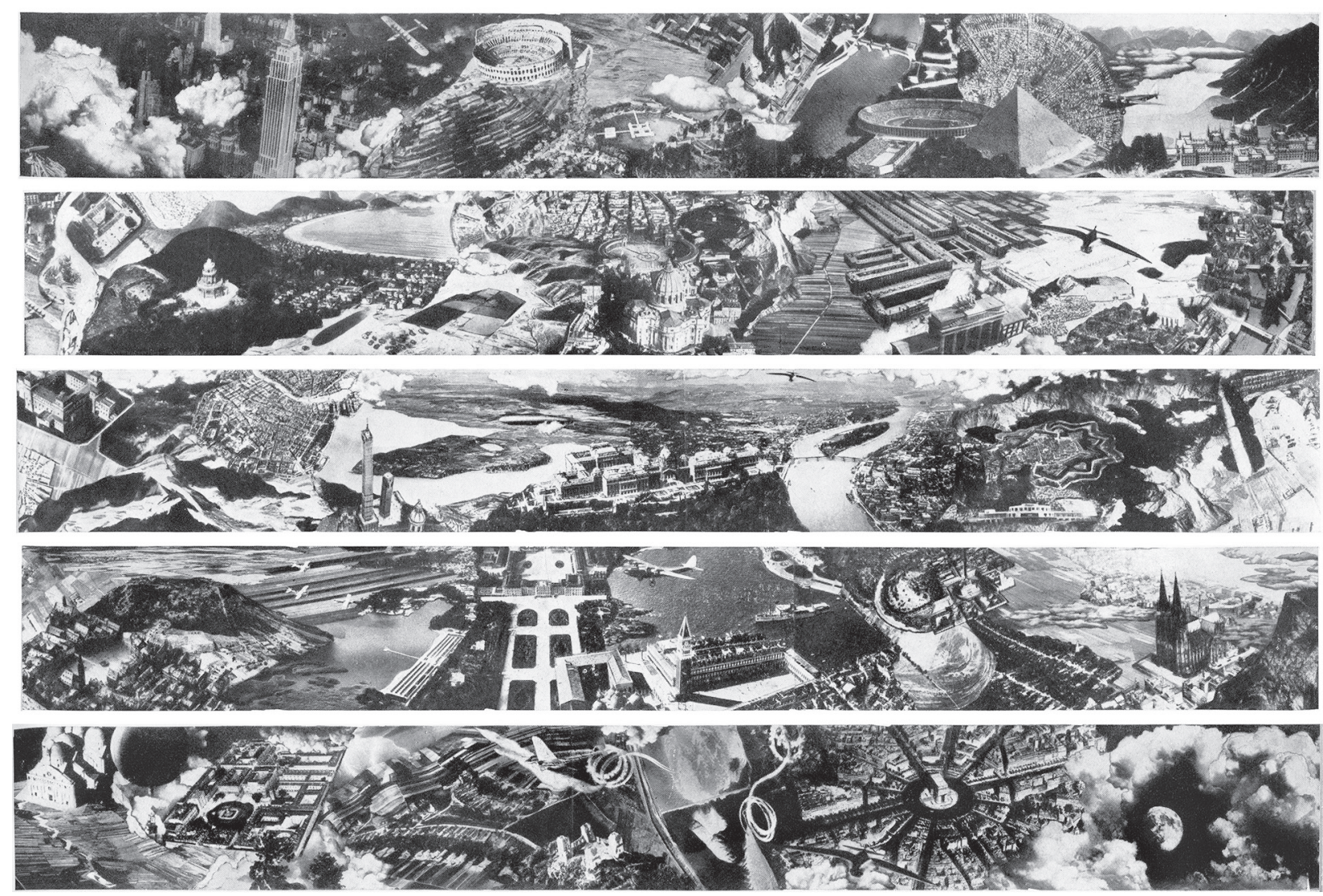

Fig. 100. Contemporary reproductions of the cyclorama "The Experience of Flight" by Mrs Elemér Marsovszky, Belvárosi Fotómúhely, 1937 (published in Tér és Forma 10. 1937: Budapest 1937.

207-209, some parts again in Tükör X. 1937: BIERBAUER 1937C. 732-733)

space, without a vanishing point, was that every tiny detail could be seen and measured on them, while the spectacle as a whole offered the liberating experience of flying. This also heralded the end of the practice of designing buildings with the focus on the elevations. The volume of studies accompanying an exhibition titled "Perspective," held in Budapest in 2000, included one by Ákos Moravánszky that dealt specifically with the interpretation of axonometric projection; he referred to a volume of essays written in 1924 by the American architecture critic Claude Bragdon, who compared isometric projection to an aerial perspective that reveals the true relationships between details, his reason being that both are devoid of the distortions that usually characterise perspective, i.e., they are not held together by parallel lines, and the size of the object does not diminish with distance. Bragdon's suggestion that this is how we see things in our minds when we remember something is also interestingly apposite to the cyclorama. ${ }^{303}$ The spatial theory espoused by the Russian Suprematists also bears a close resemblance to aerial perspective; the Suprema- tists attached great importance to space that could be expanded and transformed both backwards and forwards in depth. In isometric and axonometric images, therefore, the vanishing point continues towards infinity, where there is no "near and far" and parallel lines are indeed parallel. Among the Suprematists, Malevich produced art that had many points of connection with flying, up to and including aerial photographs. ${ }^{304}$

We have no data about the criteria used for selecting the pictures for the cyclorama, nor about the method followed for putting them together, nor about the later interventions that were carried out; strangely, there are no later descriptions of the pictures either. At the same time, the cycle of images was made using hundreds of pictorial elements, following a complex editing process, with accurate alignments and an outstanding composition, which tells us that the task was carried out by an artist with impeccable combinatory skills. The touristic iconography of the cyclorama focused on travel, and its aim was to guide travellers into an unknown world, capturing their imaginations with a completely new combination of surreal 
imagery. This aim was met by closely juxtaposing pictures of differing subjects in a deliberately provocative confusion of images, creating a mixed and dynamic arrangement of photographs of settlements, landscapes, urban details and buildings. The result was a single, large continuous spectacle seen from an aerial perspective, where national boundaries were blurred together. The city layouts clash with the architectural details, which in turn clash with the natural scenery; sometimes the elements are aligned with each other, sometimes they overlap. The dominant perspective is from the air, but the pictures are edited in a way that also pays attention to the horizon of the eye by turning certain buildings around so that their front elevations directly face the viewer. As a result, within the overhead perspective, views of towns and the land that are seen with a vertical axis are mixed together with perspectival views of famous sights.

The pictures are mostly of Hungarian, Italian and German regions, with one instance each of landscapes from the Netherlands, Egypt, Switzerland and France. The indirect assumption was made that mainly Italian, German, French, Swiss and British airlines applied for - and were allocated - offices inside the terminal building at Budaörs Airport. In addition, Bierbauer visited all these countries in the course of his work, and through his contacts there he would have been able to obtain plenty of photographic material. Many of the pictures were connected to famous events of the 1920s and 1930s: the Empire State Building in New York, erected in just eleven months, was the tallest building in the world at the time; the Sphinx in Egypt was excavated for the third time in 1926. The eyes of travellers passing through the hall could not rest for a second when faced with this cavalcade of images, yet the composition as a whole would still have remained an indecipherable enigma.

The cyclorama has undergone many alterations, and as these took place at different times, the full chronology of the cyclorama, including all its changes, will - in my opinion - only be possible to clarify when a future restoration is undertaken. The following description takes account of the alterations to the condition of the photomural that are visible without any invasive investigation; where possible, the descriptions also include elements that have been cut out, replaced with different images, or pasted over. When the reinforcing pillars were constructed, the continuous circular image was cut up into sections, and the description follows these divisions. I have endeavoured to include

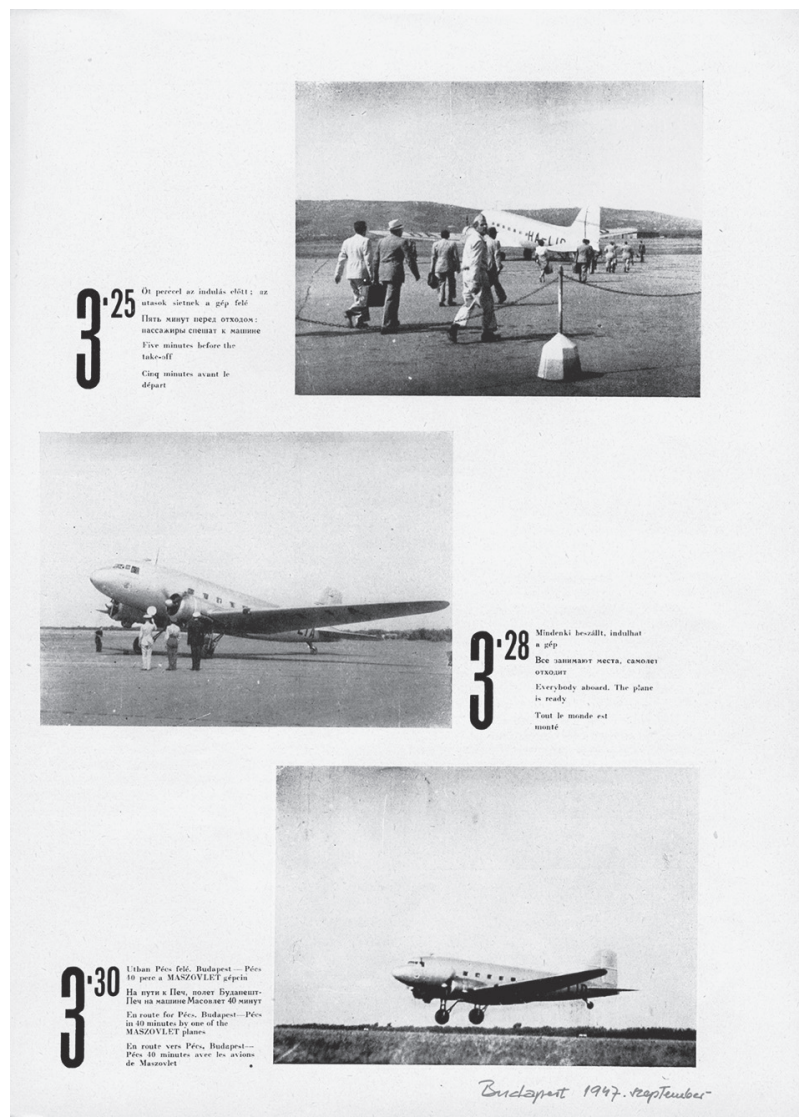

Fig. 101. "Ten minutes on the MASZOVLET Budaörs Airport," advertisement, 1946-1947 (private collection)

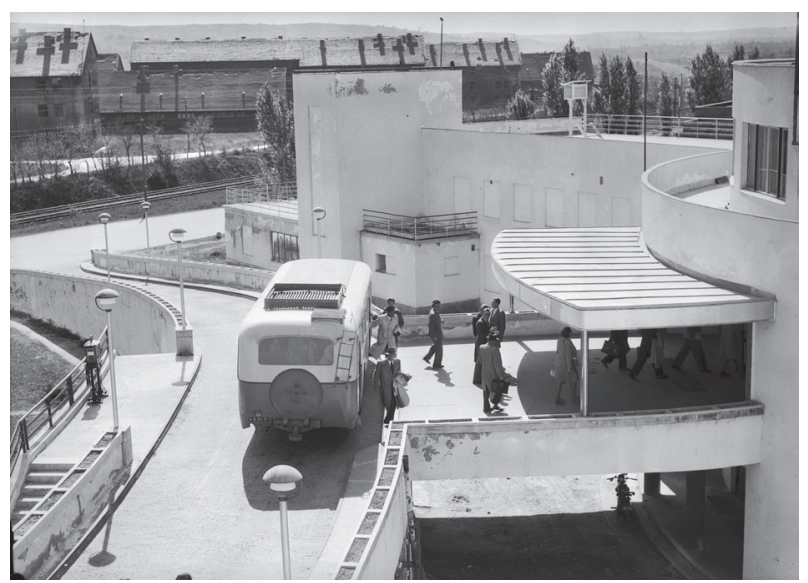

Fig. 102. Main entrance of Budaörs Airport

(photo: László Hollenzer, between 1945 and 1949; BTM Kiscelli Múzeum 56.8.20)

descriptions of the removals and alterations in the relevant places. When identifying and comparing the elements of the cyclorama, I relied predominantly on the reproductions in the 1937 edition of Tér és Forma, 305 the illustrations in Hungary from an Aeroplane, ${ }^{306}$ and photographs that record the present condition. 


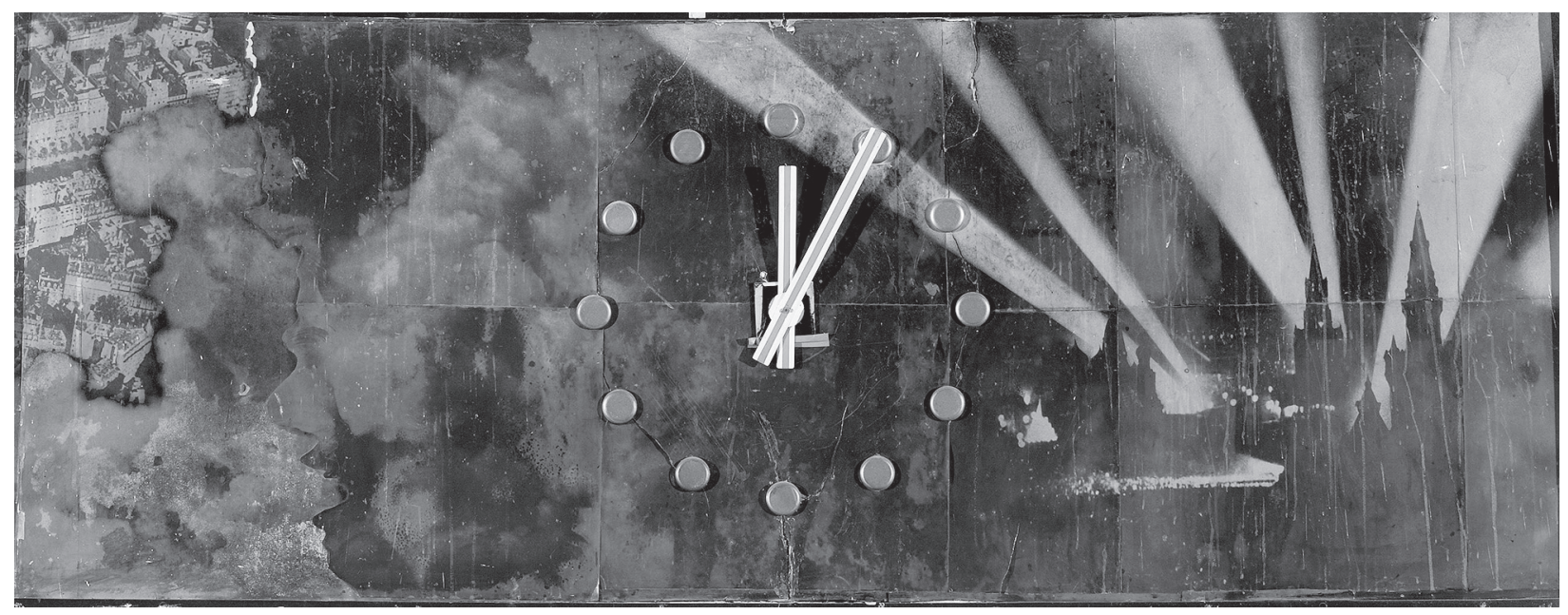

Fig. 103. Detail (section I) of the cyclorama (photo: András Ágh, 2006)

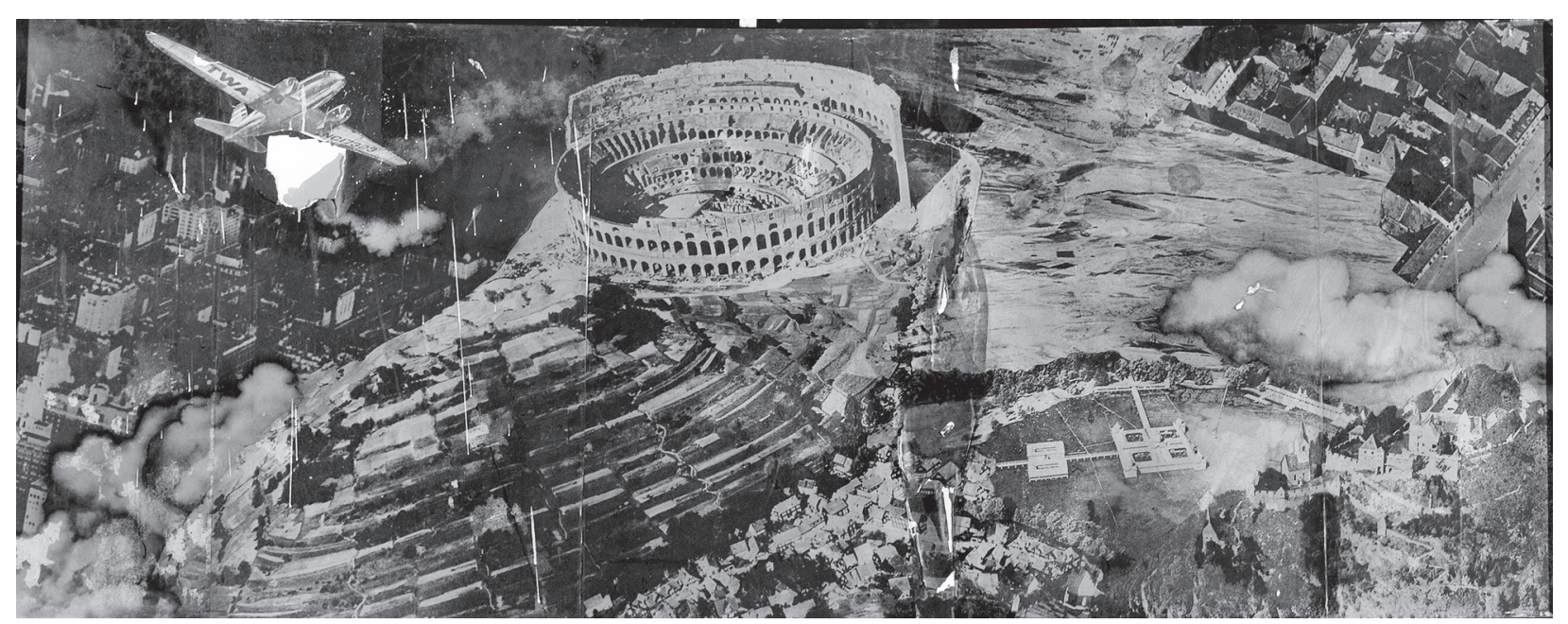

Fig. 104. Detail (section II) of the cyclorama (photo: András Ágh, 2006)

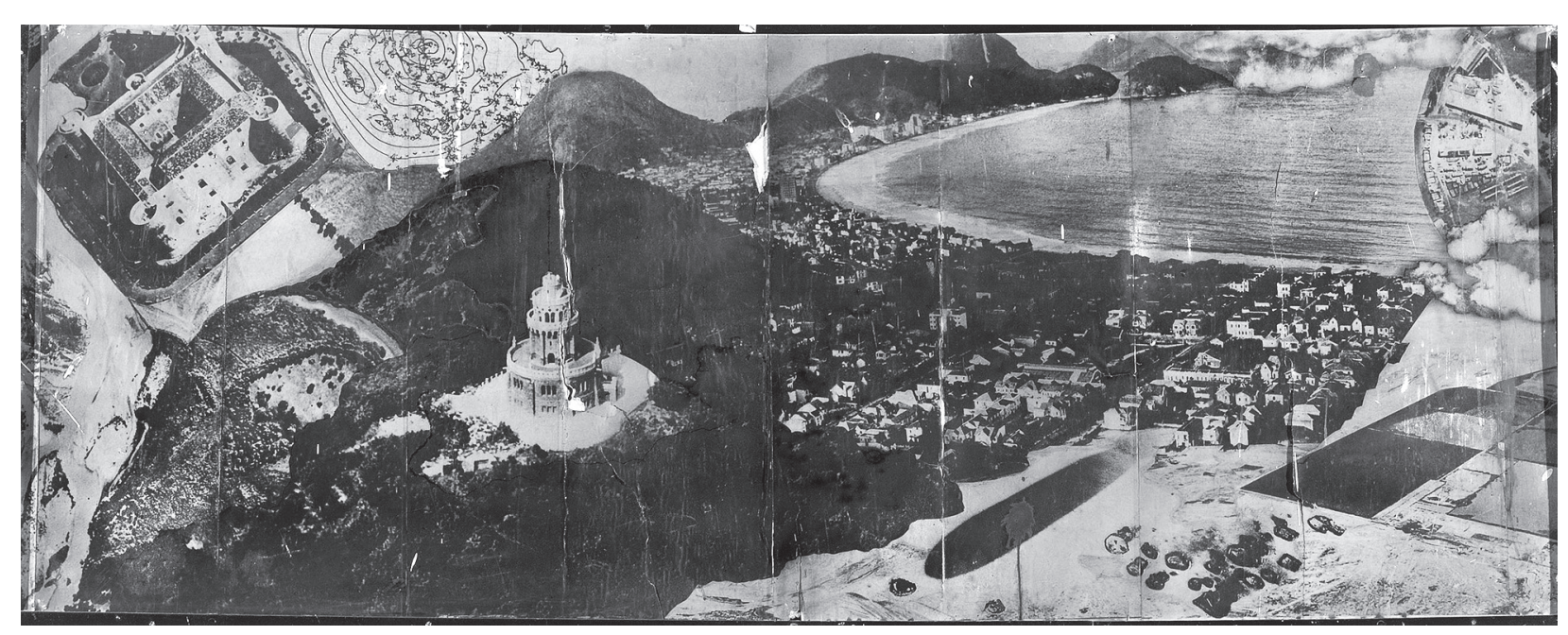

Fig. 105. Detail (section IV) of the cyclorama (photo: András Ágh, 2006) 
Section I (Figs. 3, 40, 100: from above the fifth and first pictures, 103, 124)

The section placed in the centre, directly across from the main entrance, is one of the best structured elements of the cyclorama. On the left it is still possible to see a small detail of the original composition - central Paris with clouds -, but this section is dominated by the central clock and by the silhouette of the Kremlin and Red Square (Moscow), ringed with light fittings. Removed section: the cosmic scene that "opened" and "closed" the cyclorama - where the clock is today - continued into a detail of Manhattan (New York) emerging from the clouds, clarified by the image of the Empire State Building (1931), which was later cut out. In the bottom left corner of the picture the cone of Mount Vesuvius (Italy) can be seen.

Section II (Figs. 3, 100: from above the first picture, 104, 124, 126)

The highlight of this section is the Colosseum (Rome), connected to a band of cultivated terraces and surrounded by a landscape. To the left there was originally a glider. Down on the right, close up against the foot of a hill, is the Lake Hévíz spa (Hungary, cf. Fig. 93), probably with a detail of the nearby village, which is connected to a fortress and a chapel, and then to some details of a small town (the location of the last two places is at present unknown). Alteration: in the original image, there was a glider moving from the Colosseum towards the Empire State Building. The glider was later replaced with a twin-engine passenger aircraft moving in the opposite direction, with the letters TWA (USA) on its lower wing. The urban detail beneath the plane, to the left of the Colosseum, is as yet unidentified.

The part between sections II and III (Figs. 3, 100: from above the first picture)

This part, which was cut out and destroyed when the pillar was built, showed a river running vertically; on the left was a picture of the Franciscan Church of Saint Mary of the Snows in Szeged (Hungary). This was connected directly to the Ponte Scaligero (Ponte di Castel Vecchio) over the river Adige and the Castelvecchio in Verona (cf. Fig. 85). This led into the first building in the next part of the cyclorama, the stadium in Berlin, whose left side was cut out, together with the protruding entrance hall.

Section III (Figs. 3, 99, 100: from above the first picture, 124, 126)

This composition was made by combining several starkly contrasting pictorial elements, beginning on the left with the (now cut-off) image of the Olym- pic stadium in Berlin (1936). This leads into a large overhead view of Hajdúböszörmény (Hungary, cf. Fig. 96), which has a picture of the Great Pyramid of Giza inserted into a circular sector of the town. The four-engine, unmarked passenger plane flying into the airspace above the city is also an original detail from the cyclorama. In the other half of the section, the lower part is dominated by the Parliament building in Budapest (as seen from the east, photographed from downtown Pest), behind which is a large landscape (perhaps the coast of Lake Garda, Italy?). Alteration: the original picture showed a single-engine plane flying in the same direction above the four-engine plane, which was later covered up with clouds.

Section IV (Figs. 3, 48, 100: from above the second picture, 105, 124-126)

The central element of this section, which retains its original composition, consists of two hills that overlook Budapest: János Hill, with its observation tower (Erzsébet Lookout), and Széchenyi Hill. To their left is a Renaissance castle with four round corner towers, while to their right is a seaside town. An arc-shaped layout of a city traces the rim of the sea bay, beneath which are some fields, and this is followed by a cutout part.

The part between sections IV and V (Fig. 100: from above the second picture)

The part that was removed and destroyed when the pillar was erected showed the Vatican and Saint Peter's Square, with an urban detail above them, presumably of Rome. Connected to the latter on the left was a three-quarter arc cut out from a circular-shaped city.

Section V (Figs. 48, 100: from above the second picture, 106, 124-126)

The lower left corner of this section, which also retains its original composition, shows Saint Peter's Basilica and Saint Peter's Square (Vatican, Rome), while the Brandenburg Gate (Berlin) can be seen in the lower right. The two buildings are separated by fields and mountains. Above the Brandenburg Gate is the emphatically modern detail in this section, namely a Dutch housing estate (Amsterdam).

The part between sections V and VI (removed when the pillar was built, details of the images are difficult to identify; Fig. 100: from above the second picture)

The images in this part, which was also destroyed, are hard to identify. On the left there was a sport aircraft at a banking angle (cf. Fig. 89), with unidentifiable urban details below. On the right was the begin- 
ning of the overhead view of the Île de la Cité (Paris), which continues in the next section.

Section VI (Figs. 54, 98, 100: from above the third picture, 124-126)

This section, partly altered, shows the continuation of the Île de la Cité, which is connected to an overhead image of a group of homesteads near the city of Nyíregyháza (Hungary) (cf. Fig. 97). Above them is the Castello Estense in Ferrara. The bottom-right third of the picture shows a detail of the Swiss Alps (probably the famous peak of the Jungfrau). Alteration: the top-right third of the image - diagonally across from the Alps - originally showed an overhead image of an unidentified town divided by a river flowing into the sea. This was later replaced with a composition of an unknown city, which looks to me as though it was edited together from several cut-out pictures, as suggested by the appearance of a Romanesque church and a Baroque church side by side. Judging from the focus of the panorama, it is possible that the scenery is a view of Gellért Hill (Budapest) with the Buda Hills in the background, but this can only be determined when the surviving details undergo technical analysis.

\section{Section VII}

This section was completely altered, with the original cityscape (Figs. 54, 100: from above the third picture) replaced with a new overhead image of the town divided by a river and some bridges that begins in section VI (Figs. 122, 124-126). A picture of Saint Basil's Cathedral (Moscow) was placed in the lower part of this section, in the middle of the broadening river. The modern urban detail bearing the distinctive hallmarks of the socialist realist style, which replaced Buda Castle, is unquestionably from the post-war period. The Danube is still in the same place, but the part showing Margaret Island and Margaret Bridge has been replaced with a shorter stretch of the river showing the Budapest embankment and the new Elizabeth Bridge (1962), which would date the alterations of this section to the 1960s. As the section stands today, the Danube flows into an unidentified sea bay containing a peninsula and some headlands. Instead of Gellért Hill, which would be expected in the foreground of the new bridge, there is a picture of Spasskaya Tower, the Kremlin's clock tower. A sport aeroplane was also removed, replaced with two other aeroplanes facing each other: on the left is a four-engine passenger aircraft (with Hungarian insignia), while on the right is a twin jet-engine military plane, which is unmarked but almost certainly Russian. Before it was altered, the main landscape feature of this section was Lake Bala- ton and the Tihany peninsula (Hungary; cf. Fig. 87). In the foreground were the Garisenda and Asinelli towers in Bologna, followed by Buda Castle (cf. Fig. 92), the Castle Bazaar, Margaret Bridge, Margaret Island and the central districts of the Pest side of the Hungarian capital. The image of Buda Castle was turned to be almost perpendicular to the lay of the Danube, which meant that it was face on to the viewers below. In the background, on the left, was the (recurring) image of a sport aircraft flying above the Danube.

The part between sections VII and VIII (removed and destroyed due to the pillar; (Figs. 54, 100: from above the third picture)

This part, now destroyed, featured the Pest side of the image showing the banks of the Danube, followed by the layout of the Italian star-fort town of Palmanova, with a range of mountains above it and the northern wing of the terminal building of Budaörs Airport below.

Section VIII (Figs. 54, 74, 100: from above the third picture, 124-126)

Clearly discernible in this section is an overhead view of the terminal building of Budaörs Airport in the lower left corner, with the layout of Palmanova, the "ideal city," above it (cf. Fig. 75). Rising up to the right, and dominating the centre of the picture, is a range of mountains, on the other side of which is the Great Sphinx of Giza, showing the outlines of the trenches for the third excavation, carried out in 1925-26. In front of the Sphinx's feet, in the lower right corner of the picture, is a detail of an unknown town, whose half-timbered houses and tall Gothic roofs point to it being somewhere in Germany. The other half of the image has been destroyed.

The part between sections VIII and IX (Fig. 100: from above the fourth picture)

This section, destroyed because of the construction of the pillar, showed the continuation of the (presumably German) town, which was edged with an image of the extinct volcanic hill Badacsony (Hungary).

Section IX (Figs. 100: from above the fourth picture, 107, 125-126)

This section has been altered and supplemented. A detail of the picturesque volcanic hill Badacsony remains, together with Lake Balaton and the lakeside port of Siófok, diagonally across from it. Above the hill is a group of three planes. An emphatic element of the composition here, occupying the right of the section in a vertical direction, is the image of Schönbrunn Castle and its grounds (Vienna). This is 


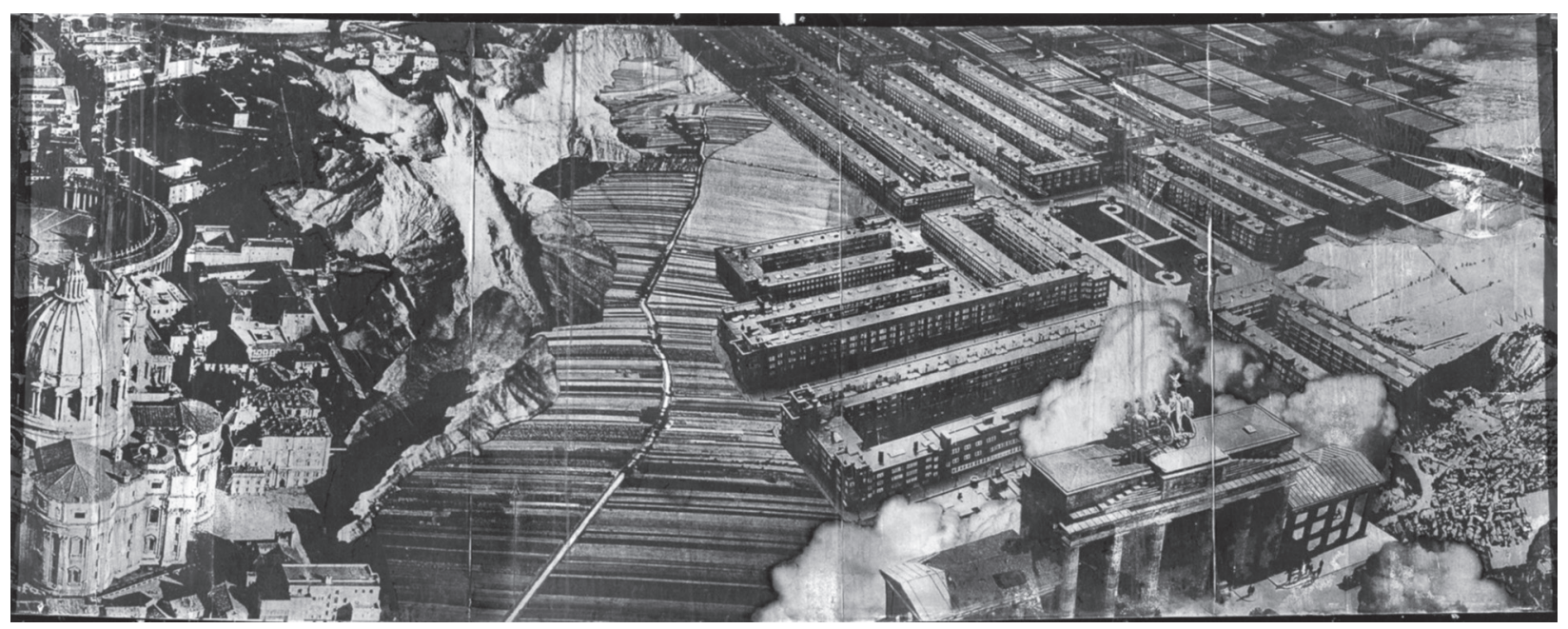

Fig. 106. Detail (section V) of the cyclorama (photo: András Ágh, 2006)

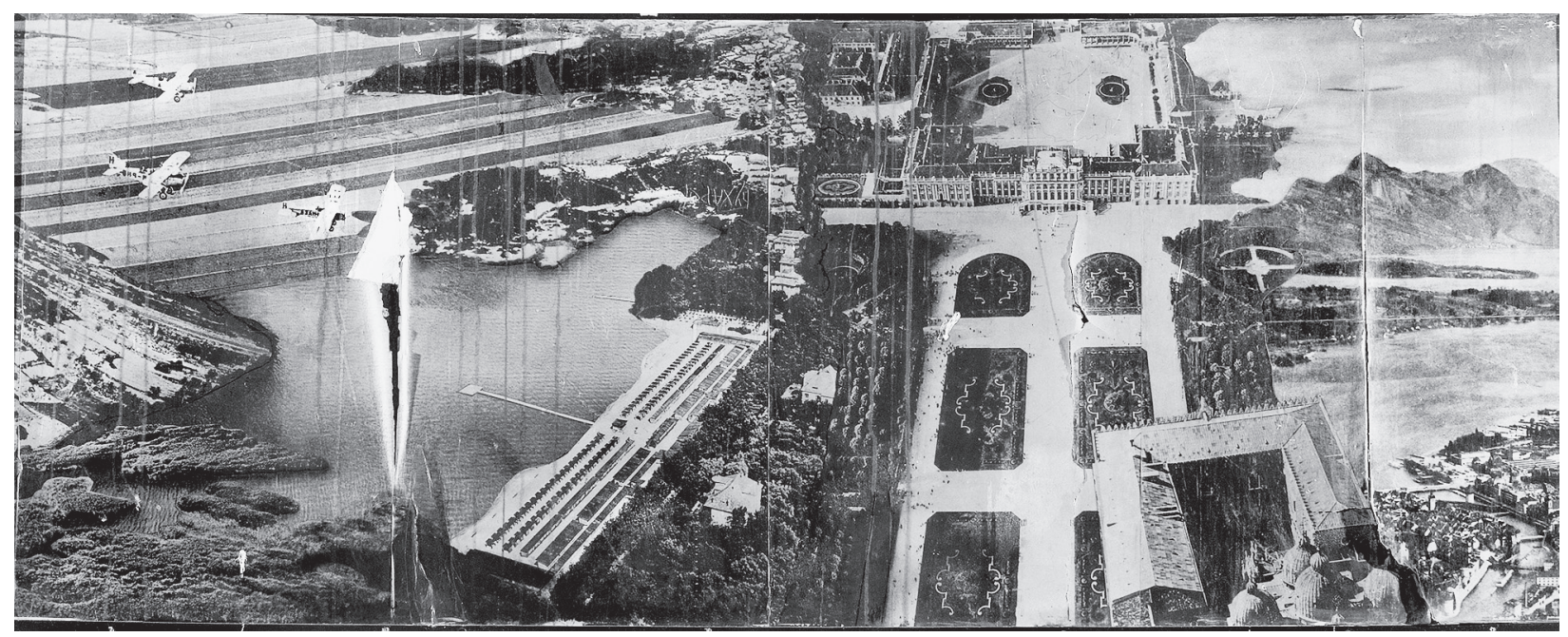

Fig. 107. Detail (section IX) of the cyclorama (photo: András Ágh, 2006)

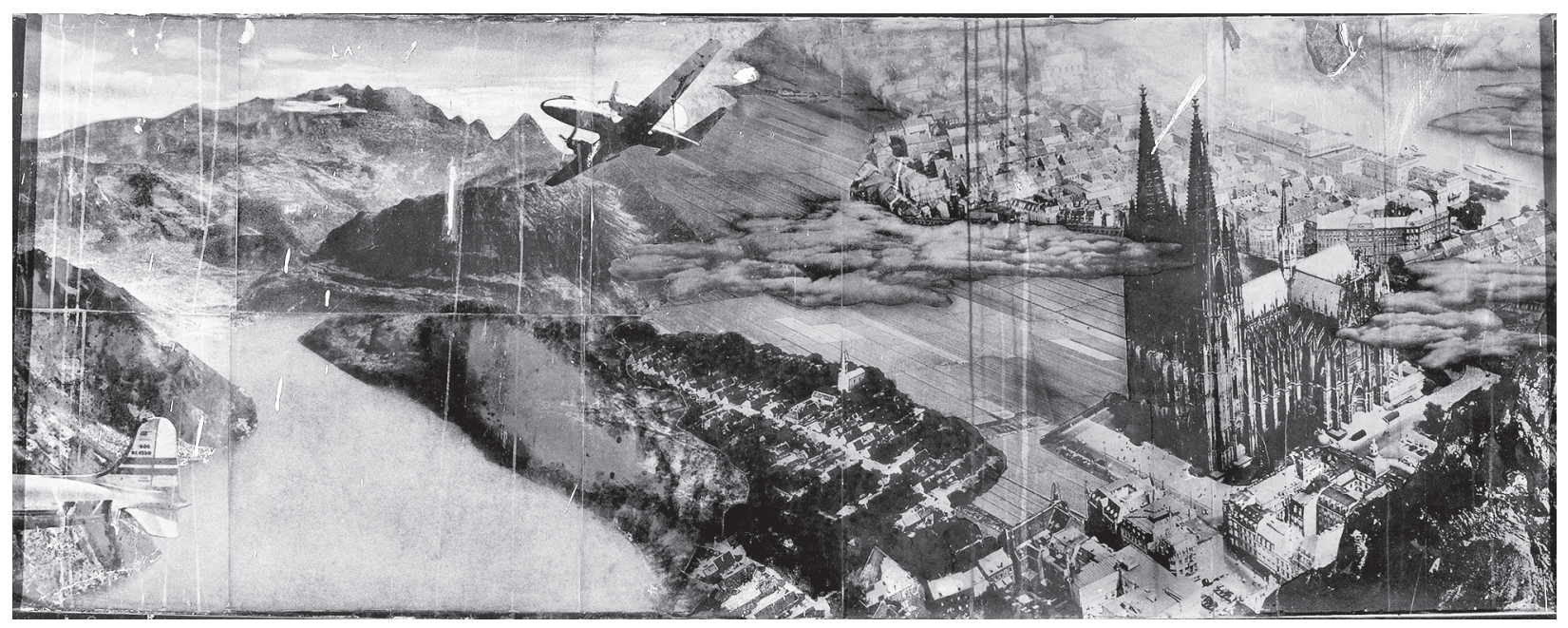

Fig. 108. Detail (section X) of the cyclorama (photo: András Ágh, 2006) 
intersected by the Doge's Palace in Venice, with the domes of Saint Mark's Basilica beneath it, which originally continued into Saint Mark's Square (cf. Fig. 86). Alteration: the Venetian square was pasted over with a new application showing an image of the old town of Lucerne (Switzerland), with a view of the Chapel Bridge traversing the river Reuss and the octagonal Water Tower, with Lake Lucerne in the background, surrounded by some mountains (which may or may not be the actual mountains around Lucerne). (Further research is required to clarify what was part of the original montage and what was added later.)

The place where the pillar is located between sections IX and X (Fig. 100: from above the fourth picture)

The removed and destroyed part showed an overhead view of Saint Mark's Square, with a ship sailing into the bay behind it and a four-engine passenger plane up in the air on the left.

Section X (partly altered) (Figs. 3, 100: from above the fourth picture, 108, 125-126)

The landscape on the left is a continuation of the new application in the previous section. Here, an aeroplane has been added to the composition. The other parts are original: the centre is occupied by the village of Ajkarendek (Hungary), next to which is the towering Cathedral of Cologne (Germany), together with its surrounding buildings. The rest of the section is taken up with a landscape.

Sections $\mathrm{X}$ and XI (Figs. 3, 100: from above the fifth picture; 109, 125-126)

The broad river that occupies the left edge of this section in a vertical direction leads to the Basilica of San Antonio in Padua. The dominant landscape element is the river Hernád (or Hornád; Hungary) with a large hot-air balloon and basket rising above it. Two short pieces are missing from the end of section $\mathrm{X}$ and the beginning of section XI, so what they originally depicted is unknown.

Section XII (Figs. 3, 41, 100: from above the fifth picture, 110, 126)

This section, still in its original condition, is dominated by views of plains (cf. Fig. 88), apart from one hill, on which Diósgyốr Castle (Hungary; cf. Fig. 95) has been placed, which in reality stands in a valley! To the left of the castle is a typical Hungarian village (cf. Fig. 94), with its distinctive "comb-shaped" layout (rows of houses built perpendicularly to the road on narrow plots) and some peasants' gates. The city view on the right is an overhead view of the Place de l'Étoile in Paris with the Arc de Triomphe surrounded by its radial avenues. The picture also shows the arcs drawn by aerobatic display aircraft, and on the right of the section a sport aircraft flying upside-down during practice can be seen.

\subsection{The form of the cyclorama}

If not for its technique, then for its monumentality alone, the cyclorama was in accordance with the mindset of art policy at the time, even though there were not any ideological or political aspects or components in the work. The authors made no difference between places in Hungary and those abroad, and presented them with the same degree of care and emphasis, ignoring national boundaries.

The traditions of the circular picture stretch back far earlier than the twentieth century. Panorama painting, invented by Robert Barker in 1787, was innovative not so much for its technique but rather for its content. Cyclical panoramas brought to life famous cities, tourist destinations, landscapes, battlefields and other historic events, and from the end of the eighteenth century onwards, ever larger and more complex compositions were created. ${ }^{307}$ Many attempts were made to make the images more lifelike and to "set them in motion." Louis Daguerre, a key figure in the early history of photography, reaped success in Paris even before his invention of the Daguerreotype by putting on diorama shows that combined panoramas with theatrical performances. Regarding the expansion of human visuality, it is interesting to note that panoramic paintings were invented almost at the same time as the first hot-air balloons (1783). ${ }^{308}$

Cycloramas, a special sub-genre of panoramic paintings, appeared in Hungary after 1870, during the second period of panorama-making in Europe. The first cyclorama exhibited in Hungary was at the National Exhibition in Budapest in 1885, and was titled Panorama of the Baths (A fürdók panorámája); this was the first cyclorama painted by Hungarian artists to be housed in its own specially constructed building. ${ }^{309}$ Cycloramas relating grand narratives received the greatest amount of publicity in Hungary at the time of the Millennium celebrations in 1896 (marking a thousand years since the Hungarians settled in the Carpathian Basin around 895/896 CE). The most important of these were The 1000-Year History of Hungary in Magic Lantern Scenes (Magyarország 1000 éves története ködfátyolképekben), Tiberius, View of Buda and Pest in 1686 (Buda és Pest látképe 1686- 


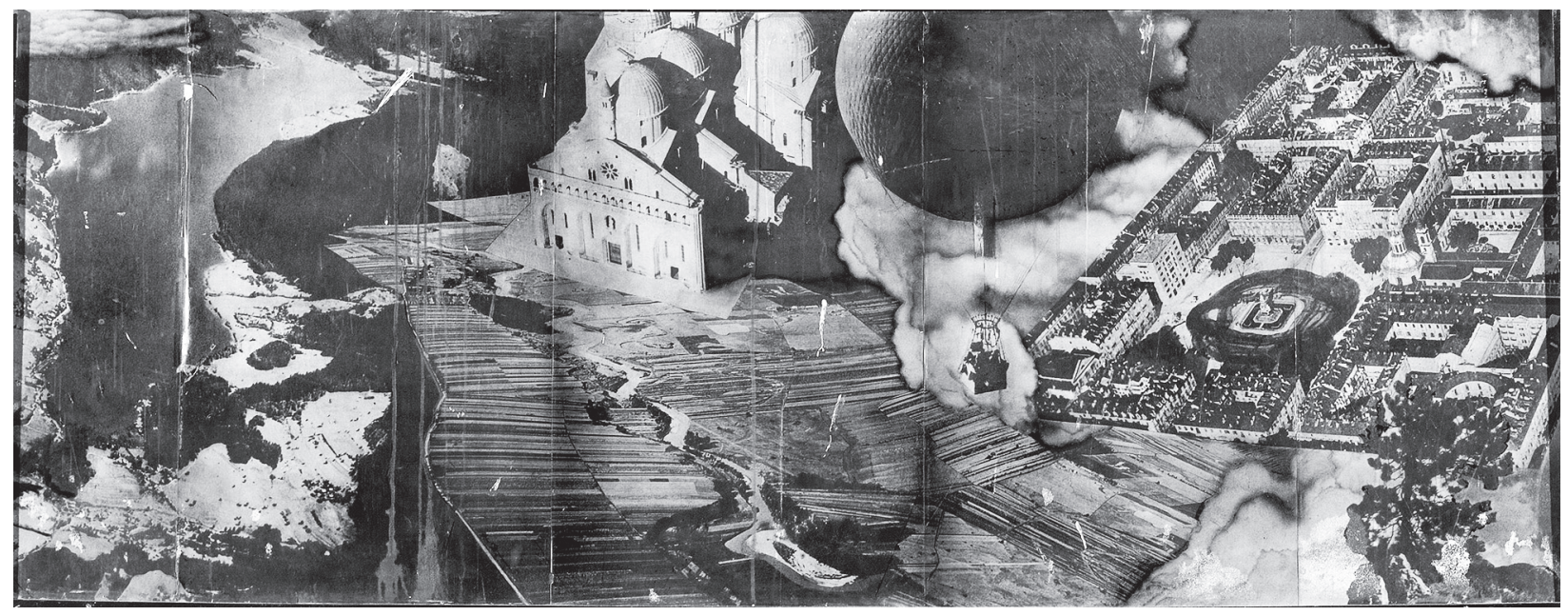

Fig. 109. Detail (section XI) of the cyclorama (photo: András Ágh, 2006)

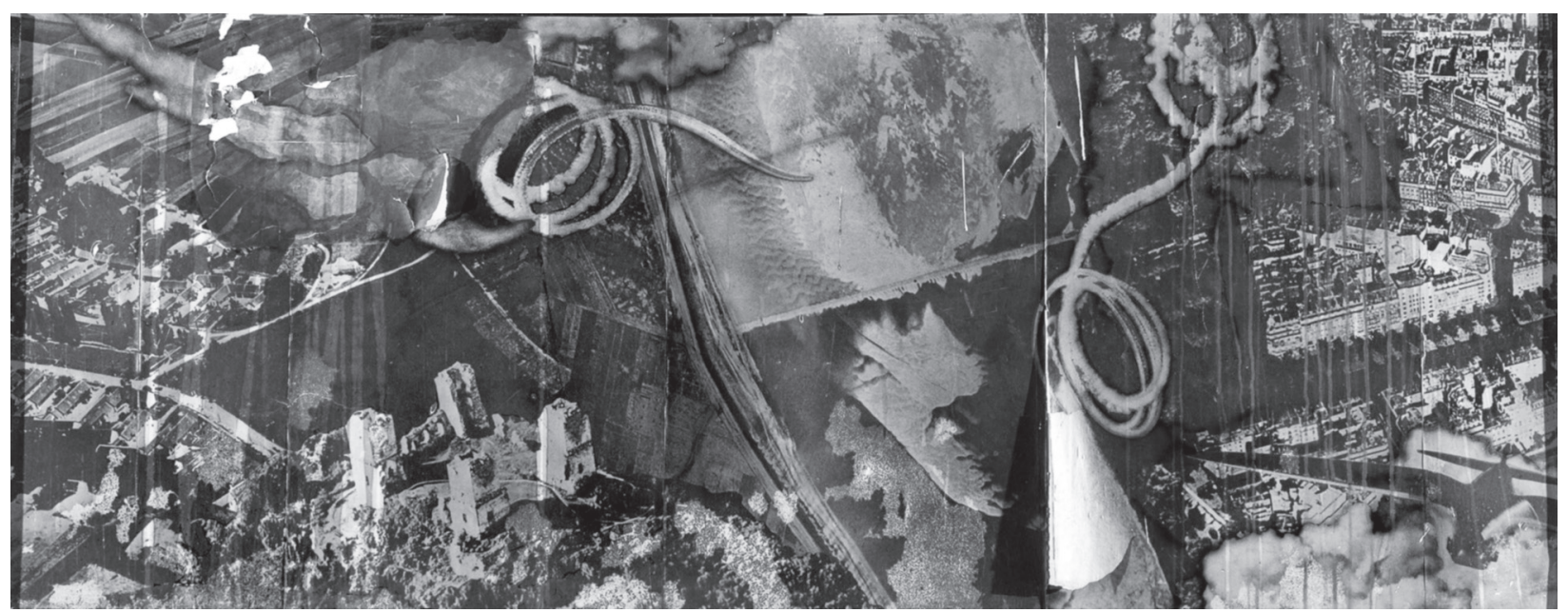

Fig. 110. Detail (section XII) of the cyclorama (photo: András Ágh, 2006)

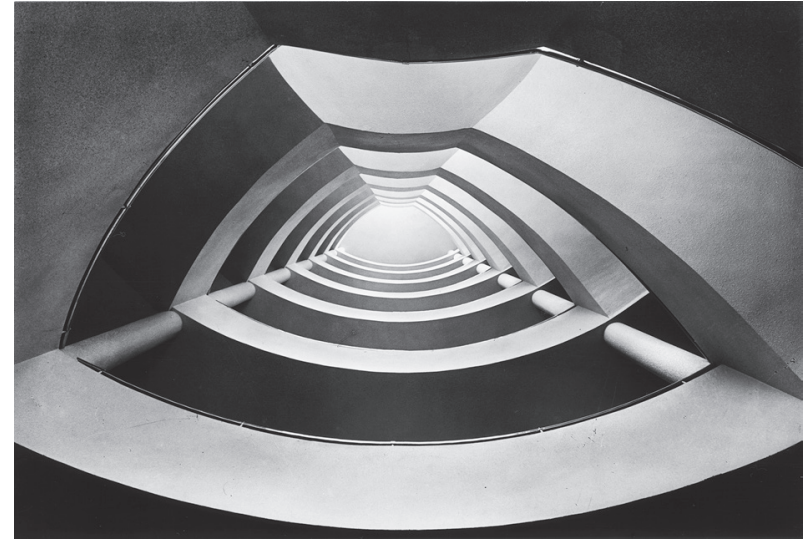

Fig. 111. 5/a Szalay Street, 5th district, Budapest, staircase detail from below, architect: György Rumszauer (photo: Zoltán Seidner, 1937; MÉM 1233)

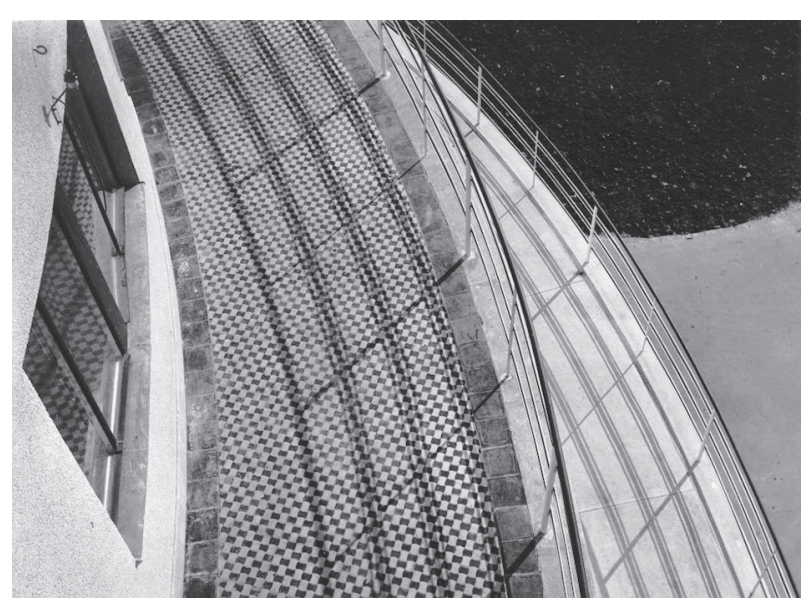

Fig. 112. Terrace of Budaörs Airport from above (photo: Mrs Elemér Marsovszky, Belvárosi Fotómúhely, 1937; MÉM Bierbauer-hagyaték GYN: 659. 21. doboz) 
ból), a cyclorama showing the Battle of Nagyszeben (Sibiu, Romania) on 11 March 1849, during the Hungarian Revolution of 1848-49, and the Bem-Petôfi cyclorama, commissioned by the Hungarian government (Sándor Petôfi, probably the most celebrated poet in Hungary, died at the ill-fated Battle of Segesvár [Sighişoara, Romania] on 31 July 1849, fighting under the command of the Polish general József [Józef] Bem, who was serving the Hungarian side in the Revolution). ${ }^{310}$ The most important work was The Arrival of the Hungarians (A magyarok bejövetele), painted by Árpád Feszty (1856-1914) in 1892-94, and depicting the founding of the nation a thousand years before. (The painting has been restored and can still be seen today. $)^{311}$

It is worth distinguishing between the types of buildings that accommodated such pictures. Panoramas were often housed in a temporary structure, even a simple stall; cycloramas, on the other hand, were generally exhibited in special buildings (also called cycloramas), which were lit from above. ${ }^{312}$ We know that when Budaörs Airport was designed, the montage was constructed to fit the shape of the waiting room, and not the other way around. Nevertheless, the waiting room is similar in form to the rotundas of the eighteenth and nineteenth centuries where panoramic pictures were displayed - even down to the overhead lighting and the fact that large crowds were drawn there to see the spectacle.

Among Hungarian painters, Miklós Barabás (1810-1898) conducted research into the question of the cyclorama in 1863, taking a particular interest in how a scene occupying an entire circle (or more precisely, the entire inside of a cylinder) could best be structured from the perspective of the viewer. Similarly, when the cyclorama in Budaörs Airport was being planned, calculations had to be made of the precise angle, dimensions and format of the work in order to make it as natural as possible for viewers to observe the photomontage in situ. The "moving panoramas" that were popular in Europe and America, which imitated the effects of travelling by train or steamship, also provided important lessons. The experience of a journey along the Mississippi, for example, or from London to Hong Kong, could be recreated with the help of transparent canvases and long, painted strips of paper, which were moved according to a set choreography; such shows did not even require a special building. ${ }^{313}$ Moving panoramas and 360-degree cycloramas made with the intention of generating the illusion of motion can easily be considered precedents for the photomontage installed in Budaörs Airport and for other similar compositions.

\subsection{How the cyclorama was influenced by avant-garde movements and the spread of the overhead perspective}

The influence exerted on modern architecture by the aerial perspective, as a third dimension to visual perception, first appeared in the conscious transformation of the overhead view of buildings, with the construction of roof terraces, flat roofs and roof gardens. Its architectural use in urban planning made it possible to obtain a better overview of larger areas, while in the art of photography - in all its fields - the composition became much more free and radical (Figs. 111-114). This change in perspective can be conceived of as a unique aspect of the art movement of the period, which Moholy-Nagy wrote about in 1929: "A bird's-eye view of the landscape is today a useful guide to the airplane pilot. In the near future views from above, both in representations and in nature, will be familiar to everyone." 314 Among the ways in which the aerial perspective was used in art (architecture), certain buildings were designed with a floor plan whose silhouette resembled that of an airplane or a bird in flight when seen from above, or a schematic representation of one. The floor plan of the terminal building in Budaörs Airport is a concrete example of how the shape of a building can be designed unmistakably to reflect its function; the pavilion of the Aviation Building at the New York World's Fair (1939) was another. ${ }^{315}$ It is interesting to note that after Budaörs Airport was opened, the contemporary press responded specifically to this aspect of its shape, with some comparing the building to an eagle about to take off. The importance of the spectacle of the building as it came into focus from the skies was also recognised by the representatives of the capital, who emphasised that the airport was the first contact visitors would have with the country's culture, architecture, decorative tendencies and hospitality. The same thoughts were echoed, almost word for word, by Bierbauer in 1938, when he justified using the architecture of airports as a means of conveying not only the novelty of flying and the idea of the global citizen, but also a sense of the national character. ${ }^{316}$ Bierbauer's arguments were surely influenced by the national political trends of his times, because by the 1920s, the architecture of international airports was otherwise moving inexorably away from a reliance on national style hallmarks. 


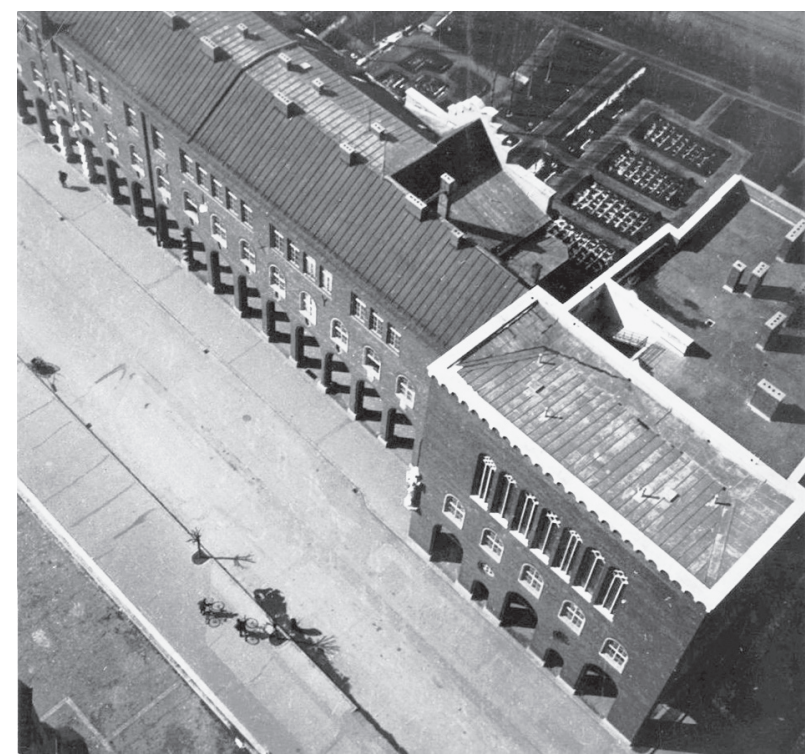

Fig. 113. Photograph by Miklós Müller sent to the magazine Modern Photography (1936/7): "Architecture" (Dóm Square in Szeged, architect: Béla Rerrich, 1928-1932) (IPM FLT 24465-1)

Architecture adopted many ideas from modern vehicles, which served as examples of functionalist, rationally built structures. Large ocean liners showed how to optimise the use of small spaces (cabins, kitchens), while streamlined shapes also began to appear in buildings. In 1921 Le Corbusier, writing in the columns of L'Esprit Nouveau, drew a parallel between the future tasks of architecture and the functionality of machines, such as steamships, aeroplanes and automobiles, which represented the age's highest degree of perfection in form and design. In the oft-quoted chapter from his book, Towards a New Architecture, entitled "Eyes which do not see," he focuses on the architectural spectacle, leaving us in no doubt that a modern building must also work as a picture ${ }^{317}$ (Figs. 115-116). This notion is echoed in Aircraft, Le Corbusier's work from 1935, only here it is flight, bird's eye imagery and flying machines that are presented as the experience of the age (Fig. 117). ${ }^{318}$ A carefully looked-after copy of this book was in Bierbauer's library, a key work on the combined topics of architecture and flight.

Countless authors have written about how flight inspired avant-garde art, from Antonio Sant'Elia (Manifesto dell'Architettura Futurista, 1914) and Marinetti (the Futurist "aerobanquet" in Bologna, and the Manifesto of Aerial Architecture, 1934) to the present day, and the mutual influences are multifaceted. Researchers into the Cubo-Futurist and Suprematist works of Malevich also investigate the extent to which the visual language of Suprematism was inspired by the kind of aerial pho-

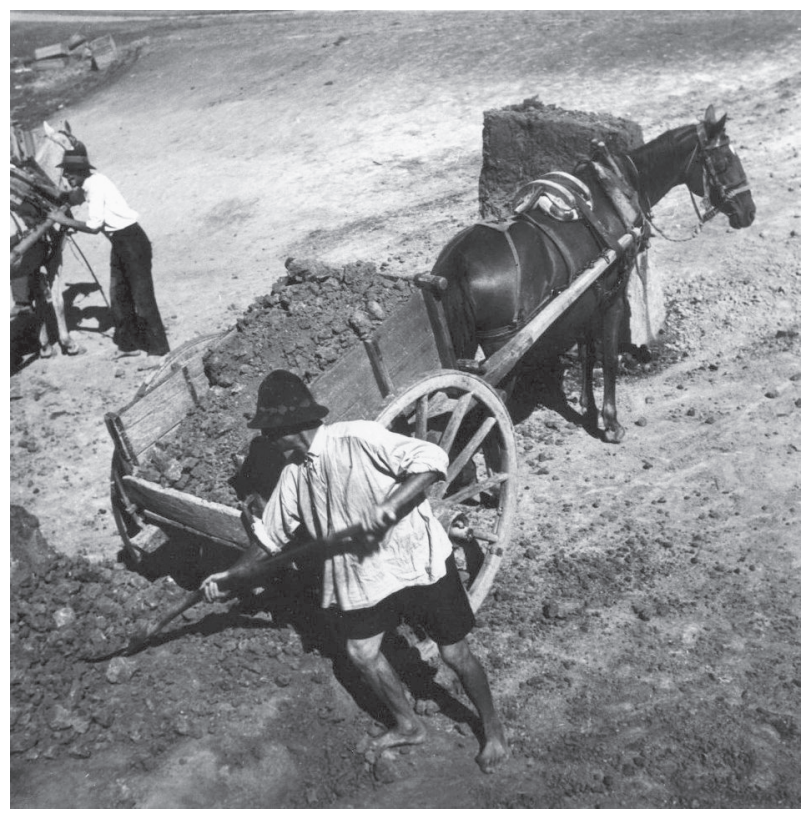

Fig. 114. Social photograph by Miklós Müller, 1930s (IPM FLT 24674.1)

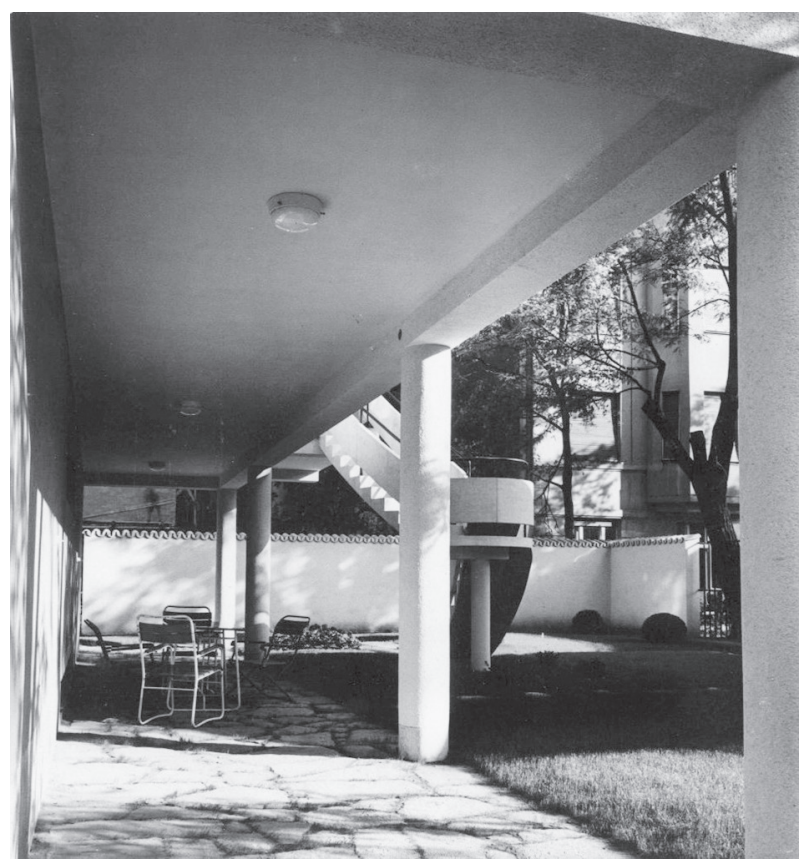

Fig. 115. Villa in 10 Bajza Street, 6th district, Budapest, architect: József Fischer (photo: Zoltán Seidner, 1936; IPM FLT 22761)

tography that encourages abstract ways of seeing. ${ }^{319}$ The following quote unravels the interconnectedness in Malevich's work between aerial photographs and spirituality: "... If all artists could see the crossroads of these celestial paths, if they could comprehend these monstrous runways and the weaving of our bodies with the clouds in the sky, they would not paint chrysanthe- 


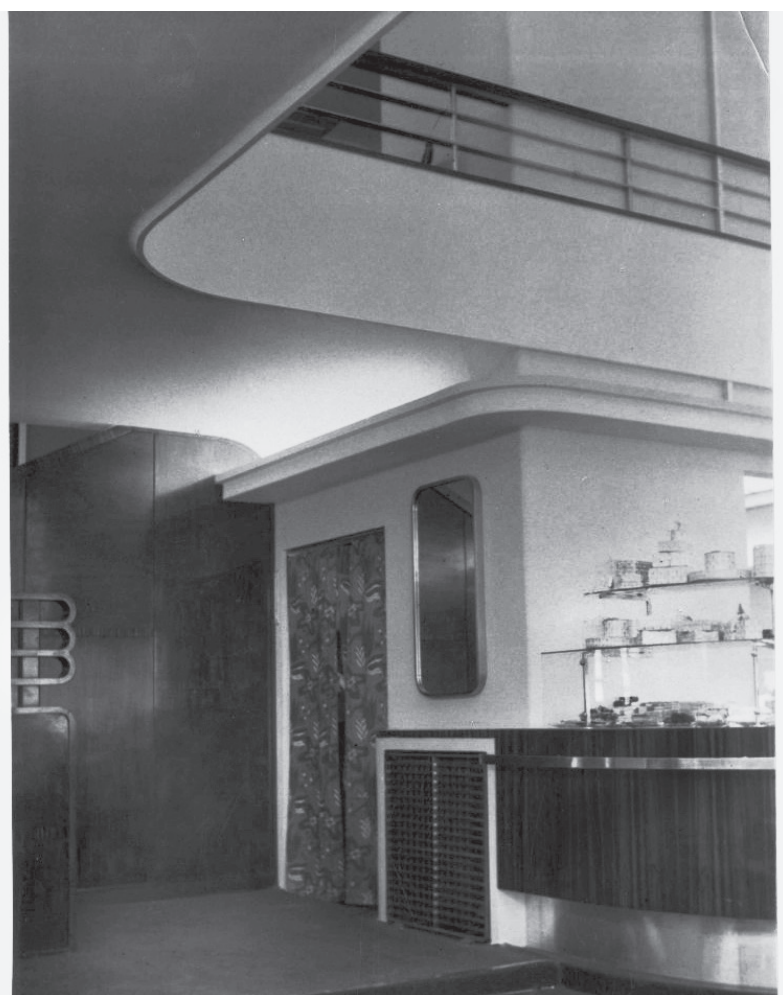

Fig. 116. Detail of Flóris confectionery, Vörösmarty Square, 5th district, Budapest, design: Gyula Kaesz, architect: Sándor Strauss

(photo: Károly Escher, 1931; IPM FLT 24446)

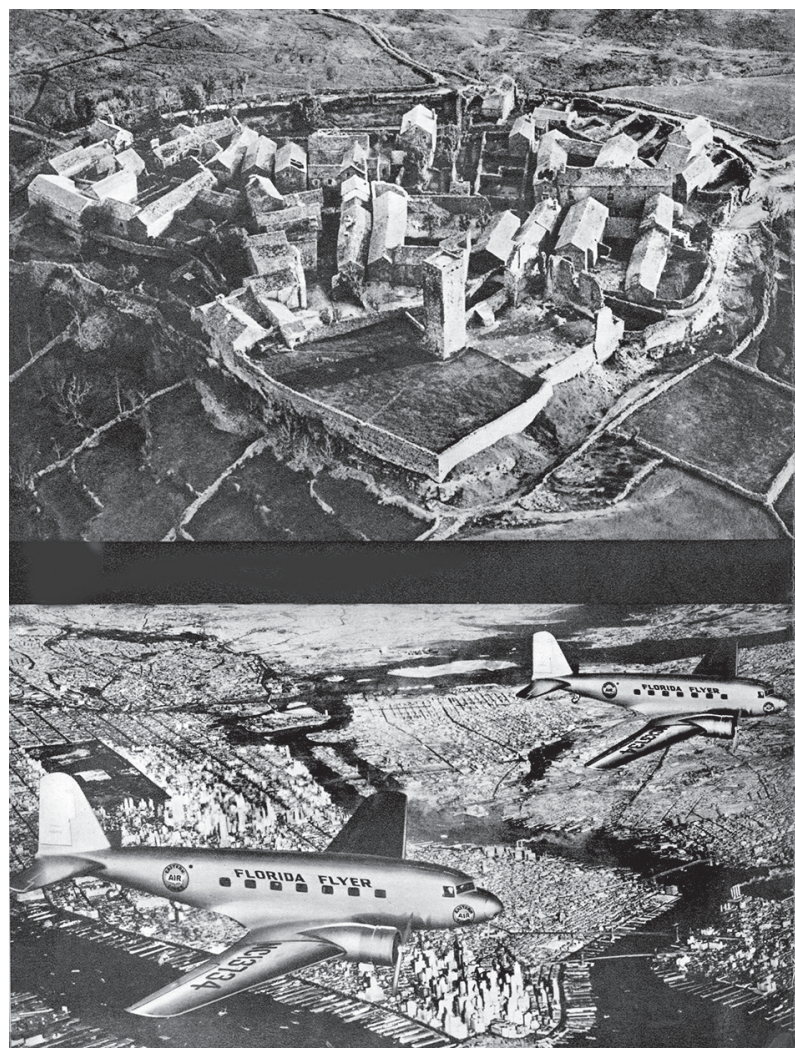

Fig. 117. Aerial photographs: French village, 800 m. up, with ruined fortifications and now abandoned; Douglas Air Liners over New York (published in LE CORBUSIER 1935.

Figs. 97-98)

out a few aspects, mostly because of the analysis of the cyclorama. The very first aerial photographs were taken in 1858 by Nadar from the inside of a hydrogenfilled balloon, thus heralding in the age of imagery seen from a bird's perspective. For a long while aerial photographs were only used for reconnaissance, first in the Austro-Italian War (1859), and then in the American Civil War (1862) and the Franco-Prussian War (18701871). Nadar initially even took a dark room up with him in the basket of the balloon, although later he took only a few cassettes, and processed the images back at home. Changes came after 1880, with the invention of dry plate photography, and again around 1910, when stereoscopic cameras producing three-dimensional aerial photographs were fitted to airships. As aerial photographic reconnaissance replaced the work of the naked eye, air defences meant that aeroplanes were driven to ever higher altitudes.

The twentieth century was the century of speed, and this also gave momentum to aerial photography. Using fixed cameras, by the 1920s it was possible to take usable pictures from a height of up to 7000 metres, and aerial photography was taken up 
by hobby pilots, air tourists, urban planners and artists working in certain fields. Specially made cameras, with an extra-long focal length, were used for these purposes, and the lens was permanently set to "infinity." They worked in the same way as terrestrial cameras, although their weight $(6-18 \mathrm{~kg})$ precluded them from being used as handheld devices.

The most systematic use of aerial photography was in the field of cartography. The science of photogrammetry can be divided into two main branches: planar photogrammetry, and spatial photogrammetry (also called stereophotogrammetry). In planar photogrammetry, the directional axis is vertical and the plane of the images is parallel to the land below. When the directional axis is tilted away from verti$\mathrm{cal}$, the plane of the image will also be at an angle, and the perspectival distortions arising from the tilt in the camera's optical axis are corrected using an image transformer (perspective correction of the negative). Planar photogrammetric images of more or less flat land could be used directly as maps, with the scale calculated according to the altitude at which the pictures were taken; the lower the altitude, the greater the scale. When the land had greater differences of elevation, aerial stereophotogrammetry was used to provide perspectival images showing hills, mountains and buildings protruding from the land. The photographers worked with pairs of photographic plates that generated a stereoscopic effect; two images were taken of the same detail of the ground below, and the images were later edited together to create a three-dimensional image.

After the break-up of the Austro-Hungarian Monarchy, Hungary formed its own cartographic organisation, independent from its predecessor based in Vienna: the Hungarian Military Cartography Group, which included the Department of Aerophotogrammetry, focused mainly on making maps for the Hungarian army. The aerial division was led by István Petróczy, who also commanded the photographic squadrons. ${ }^{327}$ The organisation changed its name in spring 1921 to the Hungarian Royal Military Institute of Cartography, and there were several later additional name changes. ${ }^{328}$ The Aviation Office, in charge of an air gendarmerie numbering 548 people, had only four outdated aircrafts in 1921, one of which was commandeered for aerial photography. ${ }^{329}$ The first photogrammetric experiment was conducted on 29 June 1923 , when Sándor Neogrády, aerial photographer, sitting on a plank and leaning out of a Fokker III type plane whose door had been removed, took a set of photos from a height of 1250 metres; the negatives were later developed in Dresden. ${ }^{330}$ Over the following years, experiments with planar and spatial photogrammetry continued under the leadership of István Rédey. The Department of Photogrammetry, founded in 1923, published many aerial photographs in its periodicals (Térképészeti Közlöny and Fotogrammetriai Szemle [literally: "Cartographic Bulletin" and "Photogrammetric Review"]), and in the yearbooks of the Hungarian Photogrammetric Society. So-called "scenic photographs," focusing on landmarks and other prominent features in towns and villages, constituted a separate group, several of which can also be seen on the cyclorama in Budaörs Airport. 331

The influence of Futurism and aeropittura ("aerial painting," "aerial perspective") on the cyclorama is unavoidable, for two reasons. The subject and composition of the work, as well as certain details, indicate that it would not have been created without a certain degree of awareness about aeropittura. In his writings, Bierbauer mentions on several occasions that the decision was taken essentially to follow the principles of Futurism and surrealism in the photomontage. Rather than providing a historical overview of aeropittura, what I intend to do here is present merely a few artistic connections that are relevant to the subject of this study. The first question to be asked is how much Bierbauer and Mrs Marsovszky knew about Futurism and aeropittura, and what kind of related information they had access to in Hungary. At the time the cyclorama was made, the period of "secondo futurismo" was emerging in Italy, and aeropittura was one of its distinctive artistic genres. The theoretical basis for this movement in painting was laid down in the views of Marinetti (1876-1944), the founder of Futurism, ${ }^{332}$ and in Futurist manifestos (La Pittura futurista - Manifesto tecnico, Milan, 11 April 1910; Marinetti and Mino Somenzi: Manifesto dell'aeropittura futurista,' 1929)333 dealing with aerial perspective. ${ }^{334}$ In aerial paintings, towns and countryside are shown in motion from the pilots' perspective, and these often vision-like spectacles are sometimes enhanced with the addition of an airplane banking at an angle (placed obliquely in the picture) or with the figures of pilots. Pictures of airports were initially used in the press and in propagandistic materials, while artists took little interest in them, even eschewing their symbolic potential. This is surprising because works of aeropittura often also featured buildings, although they were mostly oldfashioned structures. In her analysis of the Manifesto dell'aeropittura, Zsófia Beke emphasised the fact that 
the overhead perspective should not be confused with the aerial perspective based on linear projection. The overhead perspective has no spatial effect, and for a painter of aeropittura, every detail of the landscape is flattened and temporary. 335

The emergence of aeropittura is dated by modern researchers to the 1930s. It is worth noting that Giovanni Lista, the noted expert on Futurism and chief curator of the 2009 exhibition in Milan to mark the centenary of the birth of Futurism - "Futurismo 1909-2009, Velocità, Arte, Azione" -, approves of the following periodisation: 1910s: "dinamismo plastico," 1920s: "arte meccanica," 1930s: "aeropittura."336 Flight, as one of the most significant technical achievements of the modern world, was the subject of countless posters, paintings, publications, exhibitions and news reports. In this context, the Futurists used overhead (aerial) paintings and photographs to investigate new means of orientation in space and time, pertaining to their earlier research and opinions on dynamism and simultaneism. ${ }^{337}$

Kinga Dávid described the movement's theoretical principles as follows: "Futurism therefore was not interested in motion for itself, but for what lay behind it: the prospect of control over space and time. [...] It was around this that the aesthetic of machinery was constructed, while the mechanical human, made up of interchangeable parts, became its symbol." 338 Rare Hungarian examples of dynamic futuristic photographs taken during motion were created in 1927 by Ila Bárány in the private school of Álmos Jaschik (1885-1950) craftsman, art teacher and graphic artist (Figs. 118-120).

Outside Hungary, photomurals - consisting of photomontages or extra-large individual photographs - had already been discovered as a means of decoration by a variety of contemporary art movements. Architects and interior designers gravitated towards the genre (which encompassed a range of processes, such as pasting pictures together or projecting them onto the final surface), for it was ideal for creating spectacles that were suitably large but still easy to accommodate. The use of photomurals was the closest direct association that ever came about between architecture and the art of photography. This direction was predestined by the technical development of the interwar years, as well as the spirit of the age, because of the extraordinary demand for practical means of conveying the messages and symbols of the modern world. In this context, the walls of modern buildings and exhibition pavilions functioned in effect as giant screens

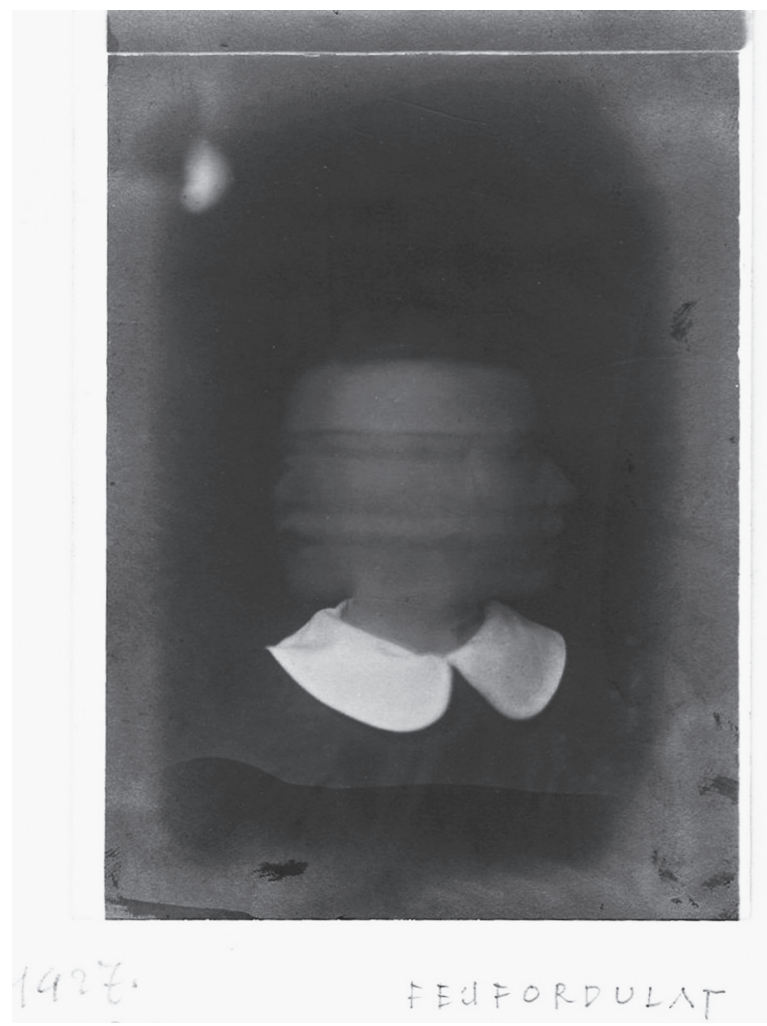

Fig. 118. Ila Bárány: "Head-revolution" ("Fejfordulat"), 1927, photo study at Álmos Jaschik's private school (IPM FLT 26032)

on which information was projected. ${ }^{339}$ In the Soviet Union, the films of Eisenstein and Pudovkin heralded the birth of a new art form, while hundreds of enormous blow-ups of propagandistic images were put on display at major European exhibitions from Moscow to Berlin. In France, exponents of the Surrealist movement were bridging the visual gap between the factual, external world and that of the subconscious (unconscious) mind; at the same time, Man Ray and László Moholy-Nagy experimented with producing photographs without the help of a camera. The "photomural" was therefore not unknown among foreign architects and artists, although for them it meant a variety of techniques. In 2012 Harald R. Stühlinger published an outstanding study of the diverse experiments with large-scale photography carried out in modern architecture from the second half of the 1920s onwards. Through examples of exhibition design, decorations on public buildings, and cinema architecture, all the main types of "photomural" are presented, including the photomontage in Budaörs Airport. ${ }^{340}$ As a close parallel, he also analyses the photographic work in the main concourse (galleria di testa) of the Central Station in Florence (1935-1936), where photographs of Italian monuments, each measuring $150 \times 100 \mathrm{~cm}$, were 


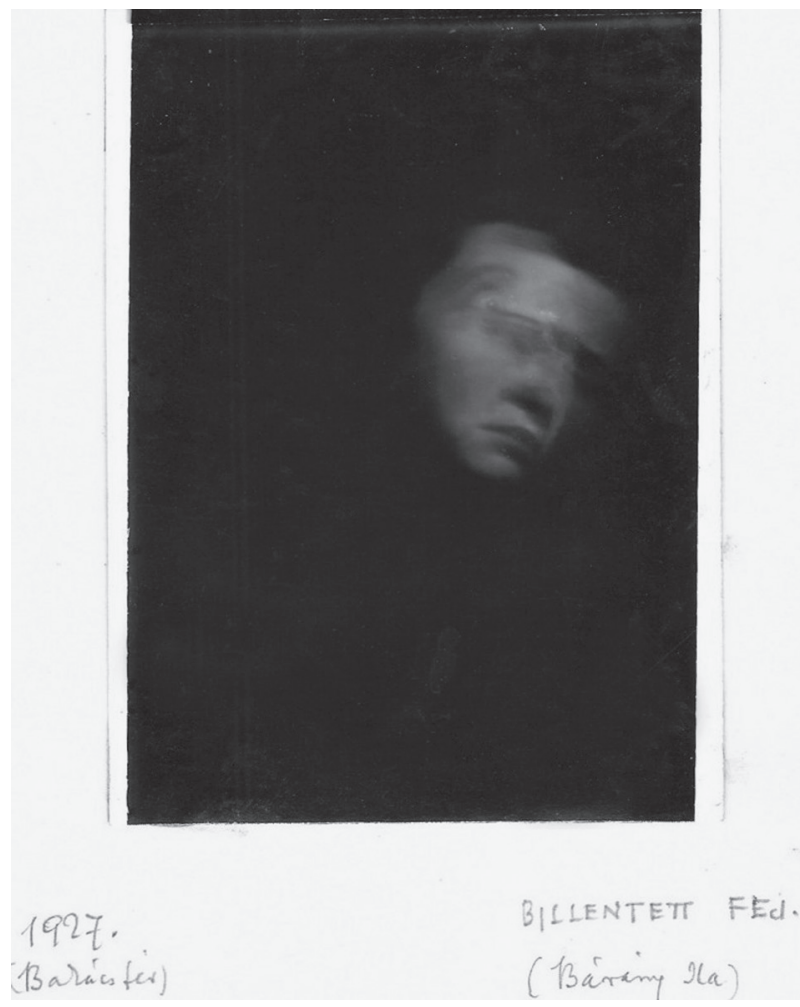

Fig 119. Ila Bárány: "Upward head" ("Billentett fej”), 1927, photo study at Âlmos Jaschik's private school (IPM FLT 26033)

displayed in a linear arrangement, as though in a picture gallery. ${ }^{341}$

As modern architecture entered its decorative period in Hungary, the photomontage produced by Mrs Marsovszky played a pioneering role. In an article in a 1947 edition of Tér és Forma, the photographer László Várkonyi mentioned in passing that photographs and montages were increasingly being used to decorate residential and public buildings, both inside and out, instead of paintings and frescos. ${ }^{342}$ This seems to be contradicted by the fact that architects in the 1950s and 1960s tended to favour works of fine and applied art when it came to decorating the walls of their buildings, although photographic installations were widely used in exhibition architecture. This type of collaboration between art and architecture was not unprecedented, of course, for in 1932 - following the Italian model - the Hungarian state had offered financial incentives to encourage new buildings to be decorated with sculptures, paintings and mosaics. ${ }^{343}$

The objectivity of photography, however, depends not just on the technology itself but far more on the degree to which a photograph meets the social and professional demands placed upon it. This is illustrated by the editions of Tér és Forma that were produced in

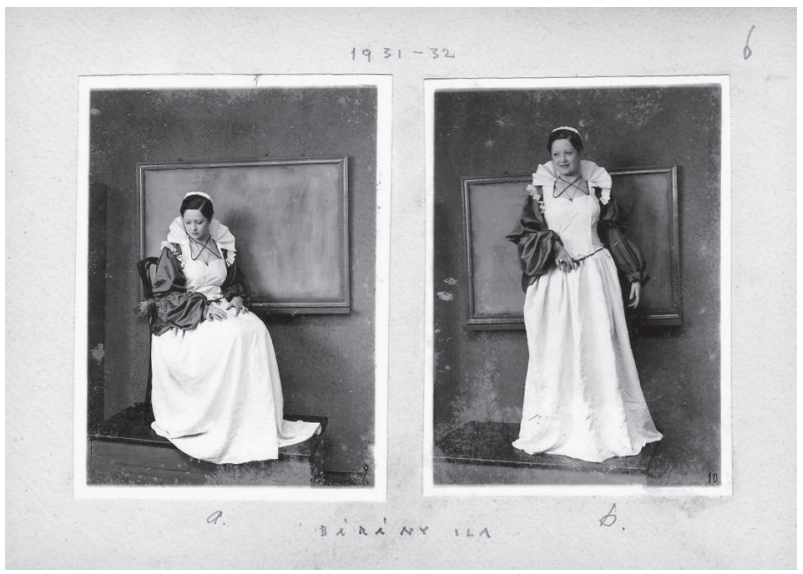

Fig 120. Ila Bárány on a party in Álmos Jaschik's private school, 1931-1932 (IPM FLT 26041 A-B)

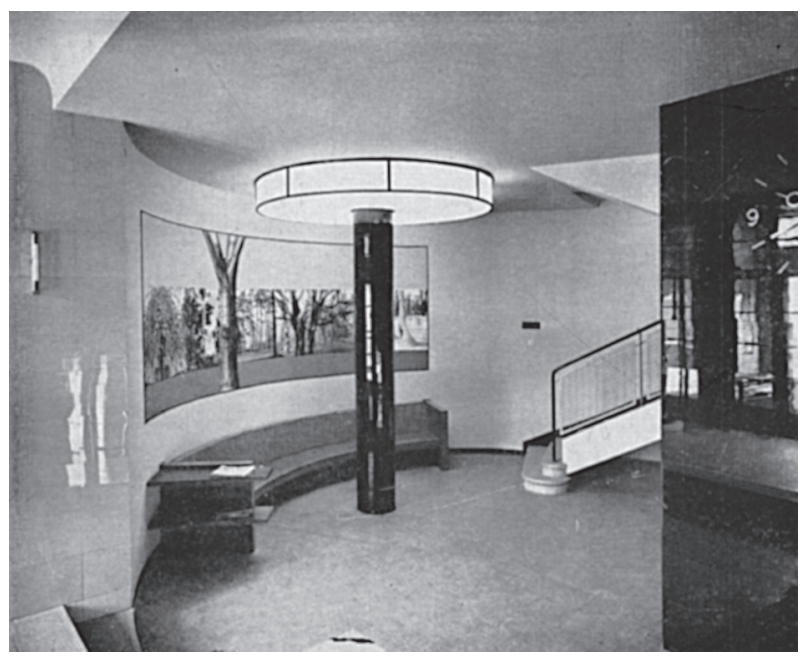

Fig. 121. Lajos Lengyel's photofresco in the lobby of the Hotel Gyopár (15 Rege Street, 12th district, Budapest), architect: József Fischer, 1941-1942 (published in FIsCHER 1942. 107)

1941 and 1942, in which there is a noticeable leap in the number of photographs and texts that refer to the essentiality of cooperation between architecture and the associated arts. Behind this increase was the determination of the leaders of Budapest to have works of art decorating as many buildings in the capital as possible. ${ }^{344}$ The colour visualisation of the interior of the Post Office Directorate in Budapest, designed by Gyula Rimanóczy (1903-1958), was accompanied with the text: "In line with modern principles, works of fine art, as decorative elements, are concentrated in one or two points"345 (Fig. 79).

In the afore-mentioned article of 1947,346 the surprising thing, in connection with Hungary, was the reference to photomurals. More traditional works of applied and fine art were easily integrated into buildings when the strict purism of modern architecture 


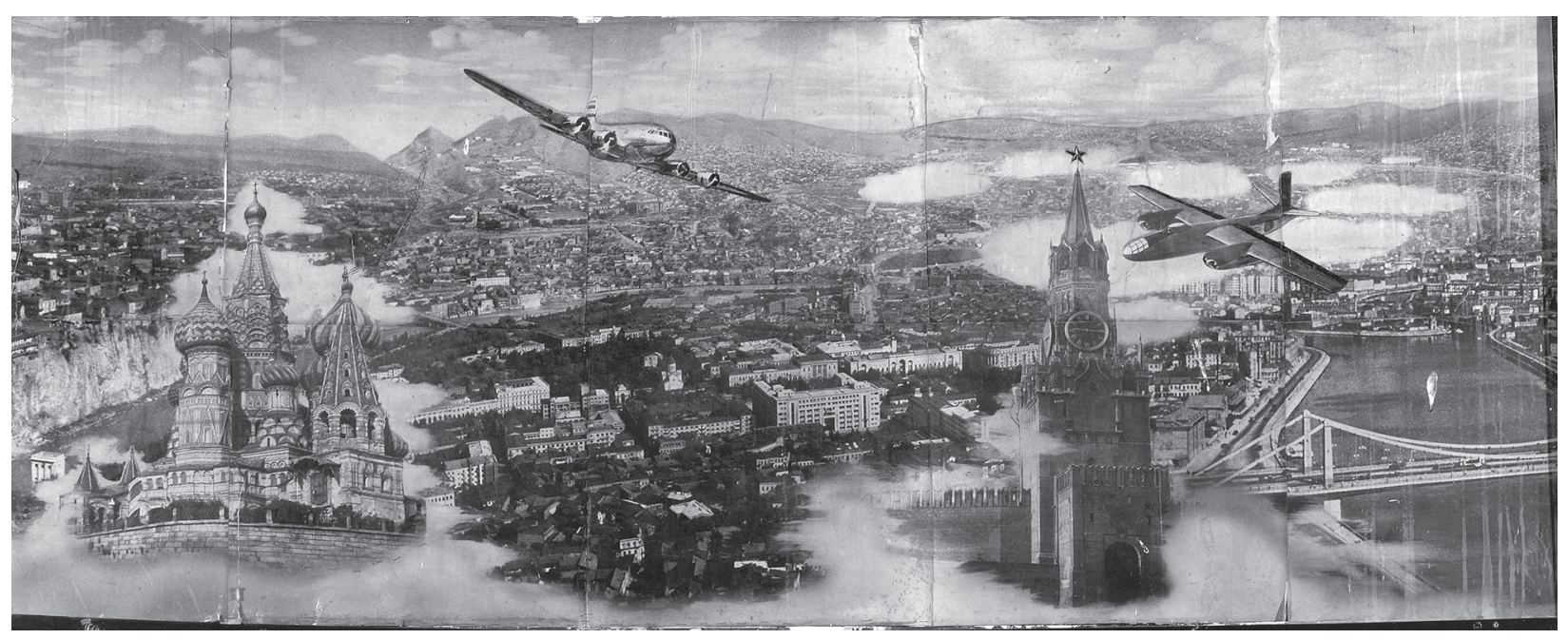

Fig. 122. Cyclorama detail (section VII) reshaped and transformed after the MASZOVLET was formed in 1946, with Russian cities and buildings (photo: András Ágh, 2006)

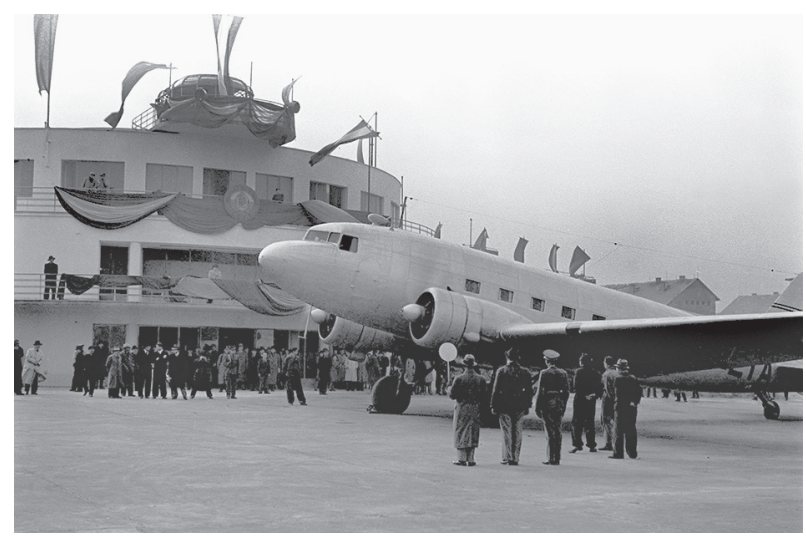

Fig. 123. The first Liszunov Li-2 passenger airliner of the Hungarian-Soviet Airline (MASZOVLET) is launched at Budaörs Airport, with a detail of the terminal building decorated for the occasion (photo: Mafirt, 1947: MTI)

began to ease. In the case of photography as an art form, however, it was not so easy for it to find its place in architecture, a rare example being the photomural decorating the vestibule of Galyatetô Hotel (Northeast Hungary), produced in 1943 by the art photographer Lajos Lengyel. Consisting of enlarged photographs of a variety of plants, the photomural sadly no longer exists, except in the form of a few high-quality magazine illustrations. Lengyel's another work, the photofresco in the lobby of the Hotel Gyopár in Budapest (1941) had a similar fate 347 (Fig. 121).

The photomontage created by Mrs Marsovszky and Bierbauer belongs to a group of artworks on the theme of flight that were produced in various parts of the world in the early period of aviation and airports. One of the earliest important works of this kind was made by the American painter Arshile Gorky in 1935, intended as a fitting form of decoration for Newark
Airport (New Jersey, USA). The mural, titled Aviation, incorporated elements of Cubist and Constructivist styles, and was derided by the public as absurd and unacceptable. Nevertheless, in 1937 the work was installed in the airport. ${ }^{348}$ Three years later, Gorky worked on the "Marine and Aviation" building at the New York World's Fair.

Another, more distant analogue of the interior of Budaörs Airport can also be found in the USA, at LaGuardia Airport (1939, New York, USA). The colourful, painted, circular mural in the waiting room is titled Flight. Measuring 12 feet $(3.5 \mathrm{~m})$ in height and 237 feet $(72 \mathrm{~m})$ in width, it was painted by James Brooks in 1940 and features human achievements in all areas of flight. The airport, the largest and most expensive in the world at the time, was designed in an art deco style by the firm Delano \& Aldrich. It was financed and built as a national project, and it was opened in 1939, the year of the New York World's Fair. ${ }^{349}$

As a result of the dynamic development of aviation technology, airports are now the most important type of building in the system of buildings for transportation, and ideas about airports have changed substantially since the earliest years. In terms of anthropology and social sociology, these buildings have evolved into communal and social spaces despite their lack of traditional urban roots. By a different approach, airports can be defined as meeting places of a multitude of technologies and cultures, that is, as "social spaces" that fulfil multiple functions (meditation, waiting, entertainment). A study of airports as cultural spaces also highlights the potential for them to function as museums, pointing out an article that appeared in The New York Times that compared the 4-6 million visitors 


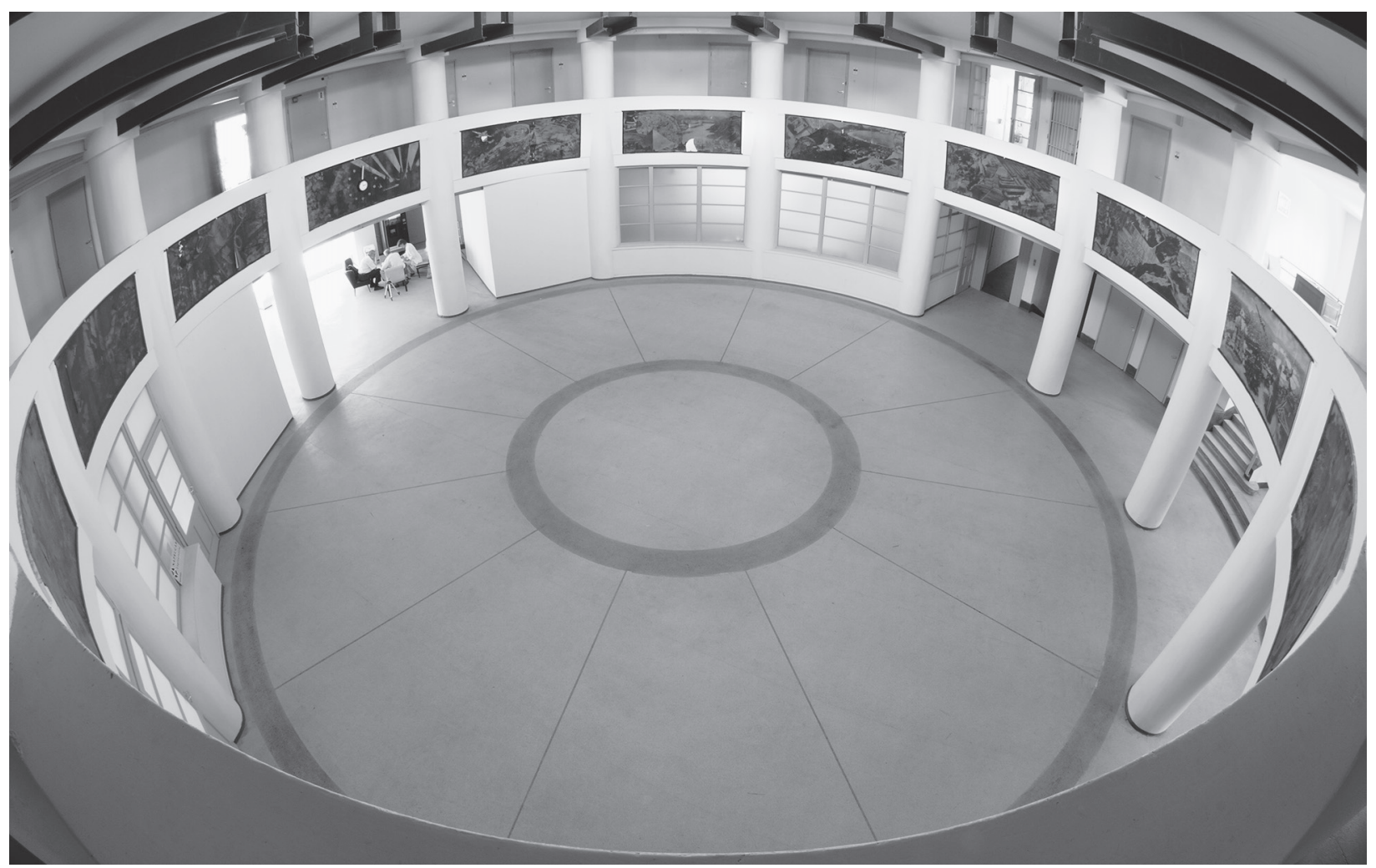

Fig. 124. The waiting room of Budaörs Airport with cyclorama sections X-XI-XII-I-II-III-IV-V-VI-VII-VIII (photo: András Ágh, 2006)

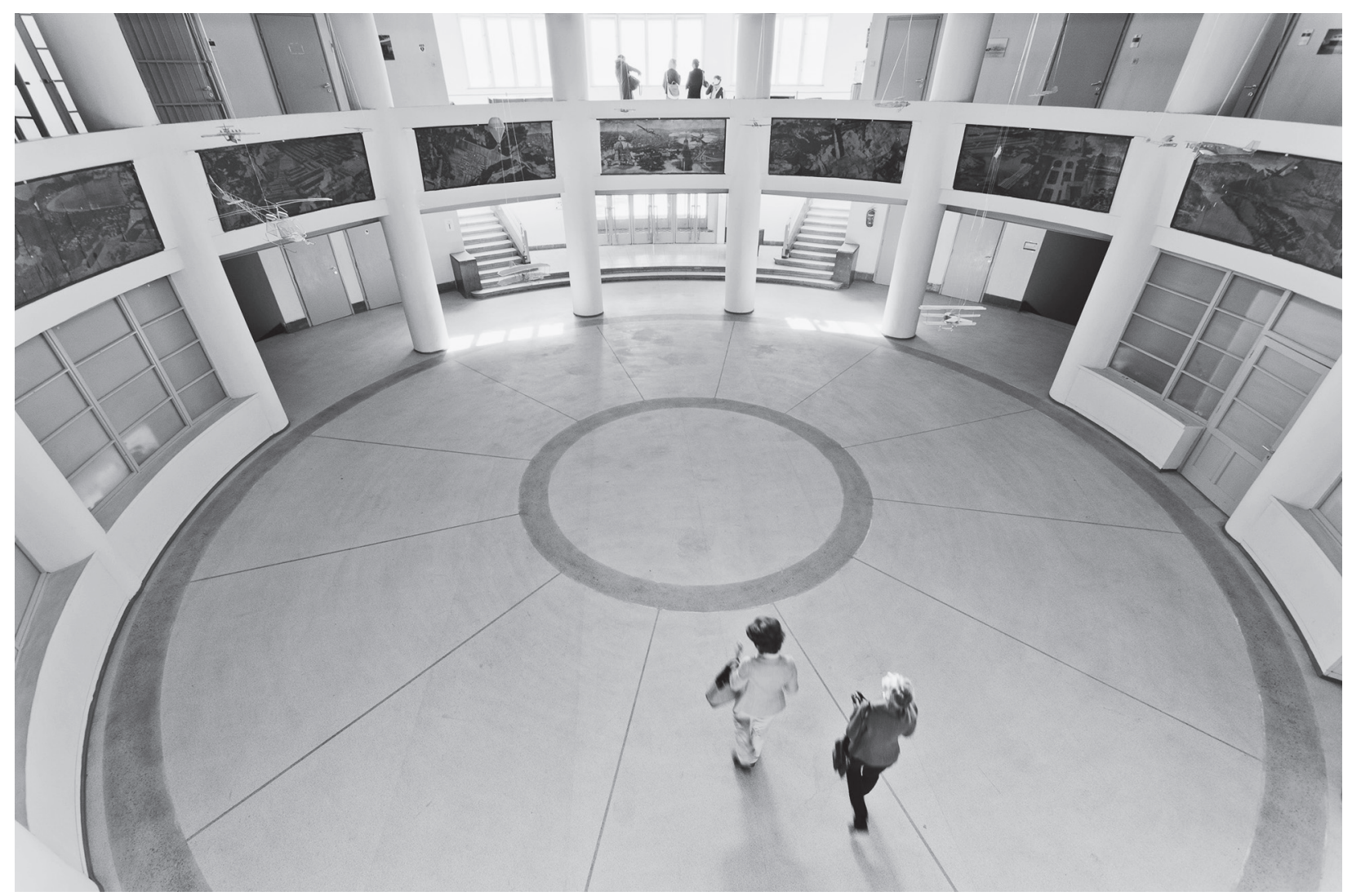

Fig. 125. The waiting room of Budaörs Airport with cyclorama sections IV-V-VI-VII-VIII-IX-X (photo: György Bencze-Kovács, 2011) 


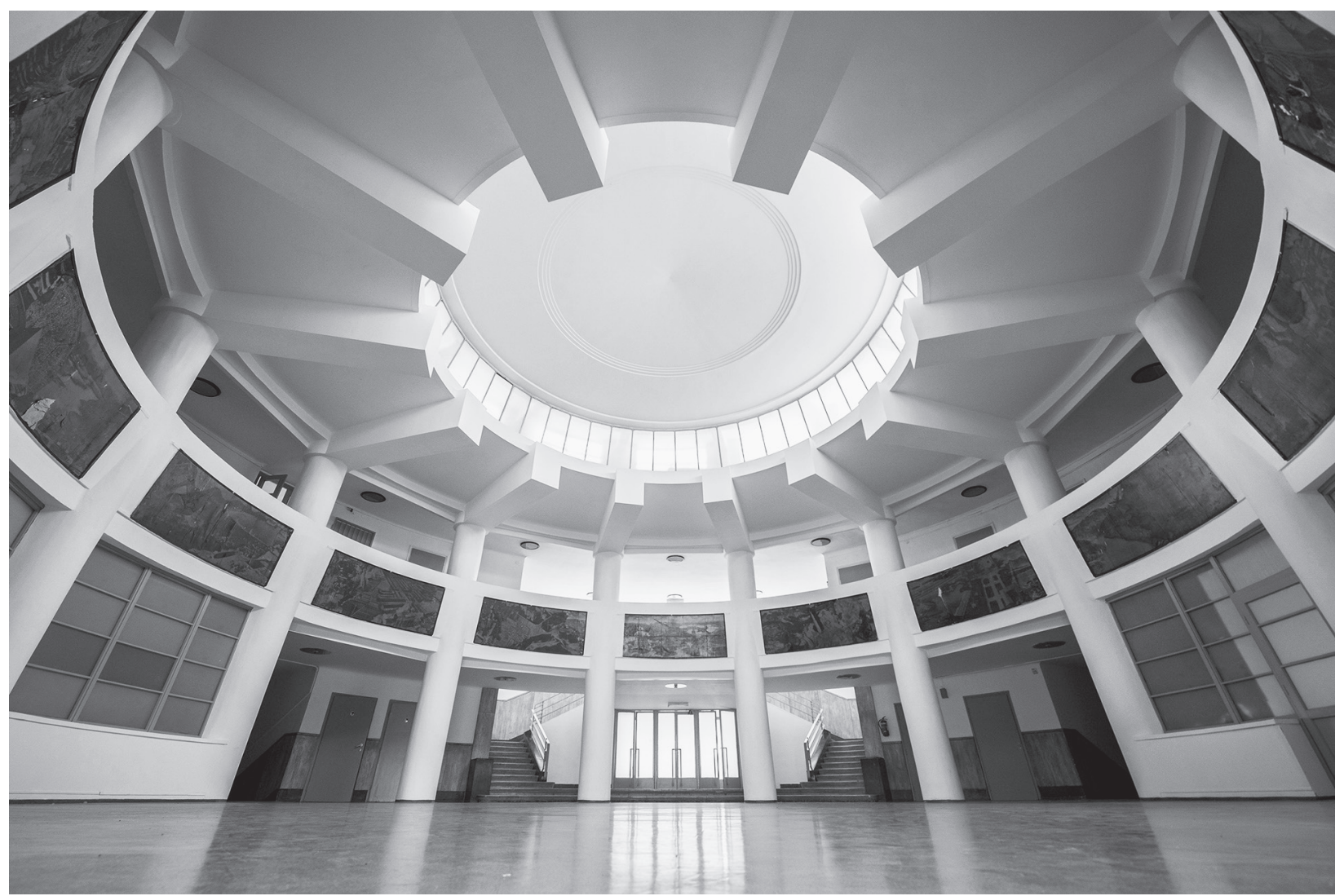

Fig. 126. Budaörs Airport's waiting room on the eightieth anniversary of the opening of the airport, 20 June 2017, with cyclorama sections II-III-IV-V-VI-VII-VIII-IX-X-XI-XII (photo: Zsolt Szigetváry; MTI DSZZS20170620106)

each year to the New Work Metropolitan Museum of Art with the 60 million people who passed through Chicago's O'Hare Airport in 1990.350 This function had already emerged in the 1930s, when certain American airports were first used as exhibition spaces. Nowadays, alongside technical criteria, the dominant aspect is design. By means of comparison, airport decoration in the 1930s focused on maps and other aids to orientation, on the history and joy of flying, and on the aeroplane itself, as the fastest way to travel; travellers these days are more accustomed to flying, and as they move around an airport they are far more likely to come across spectacular images of tourist destinations, and of course the ubiquitous advertisements. The decisive factor in it all is individual design.

\subsection{The dismantling of the photomontage "The Experience of Flight"}

Thanks to the subject and unique shape of the photomontage in Budaörs Airport, it has a place in the histories of architecture, photography and aviation. Although the building still maintains its original purpose, it is a sorry shadow of its former self. The technical condition of the airport, whose erstwhile elegance is visible only in traces, is a cause for concern, and the photomontage overlooking the waiting area has lost its unified character as a result of structural work in recent decades. Among the most urgent tasks, the severely damaged pictorial elements need to be restored and conserved. Using detailed photographic documentation taken in 2006-2008, we have assessed the spatial positioning of the cyclorama and the details of the montage, including the damaged parts and the iconographic changes made to the cycle of images after 1946 (Fig. 122). As far as I know, none of the redevelopment concepts put forward to date have dealt substantively with the importance of the cyclorama as an integral part of the interior design, or with its conservation. This is particularly unfortunate, because the montage is presently in such bad condition (damaged, faded, with parts missing) that only with proper cleaning and preserving can it be saved from further damage. It would also be necessary to carry out material and strata inspections in order to determine the precise composition and structure of the work, in particular the interventions that were 
made after the Hungarian-Soviet Airline (MASZOVLET) was formed in 1946 (Fig. 123). The most serious intervention took place at the end of the 1980s as part of a restoration programme. When the dome over the waiting room was reinforced, the cyclorama was cut up into twelve sections, because a new shell was applied all the way up the columns (Figs. 124126). This meant that parts of the cyclorama had to be removed where the columns and the balustrade meet. It would have been possible, of course, to replace the removed sections, or to preserve them in some other way, but this was not a consideration at the time. The same is true for the glass mosaic that originally covered the columns.

Based on the documents uncovered during the research, in autumn 1984 the Hungarian Scientific Society for Mechanical Engineering notified the Department of the Monuments Inspectorate of the
Executive Committee of Budapest Municipal Council about the conservation works being carried out on the building, ${ }^{351}$ which at the time was under municipal monument protection. ${ }^{352}$ After receiving the report, the head of the department, Mrs János Antal, Piroska Czétényi, immediately requested the entire documentation pertaining to the unauthorised conservation works and ordered a site inspection to take place between 26 and 28 September 1984. ${ }^{353}$ As a result of the inspection, the structural reconstruction was classified by the Budapest Monuments Inspectorate as being of such unprofessional quality that in 1985 the airport terminal building was removed from the register of protected buildings. "... as a result of the work carried out recently - without the approval of the monuments authority - on the terminal building of Budaörs Airport, the building has lost its original character and architectural values." 354

\section{CONCLUSION}

When evaluating the construction and operations of the first international airport in Budapest, the fact that the time required ultimately to bring it to fruition was longer than the period it actually functioned as a civil airport must not be ignored. ${ }^{355}$ Shortly after it was opened, the first problems of soil flooding manifested themselves, and in January 1938 the decision was taken to install drainage beneath the entire area of the airport. ${ }^{356}$ Budaörs Airport served as a civil airport only until 1950, after which it took on a secondary role, which had a knock-on effect on its further development. Nevertheless, its significance cannot be questioned, because it was created at a point in Hungarian history that was suffused with extremely difficult and complex political considerations, and it was built on a par with European standards entirely through the efforts of Hungarian industry. Architecturally, it incorporated the lessons drawn from international precedents in such a way that, in terms of overall shape, internal spatial logic and the application and artistic execution of functionalist decoration, it transcended all of them. The fact that its capacity meant that it only caught up with the first generation of international airports is another matter; Hungary did not progress to the next level of European and American development until 1950, when Ferihegy Airport, the replacement for Budaörs Airport, was opened on the other side of Budapest. ${ }^{357}$ The fate of Budaörs Airport once more came into focus at the end of 1999, when the first steps were taken towards granting it protected status as a national monument, and the building was also placed on the international list compiled by the Hungarian branch of DOCO$\mathrm{MOMO}$, underlining its international importance. 358 The terminal building was granted protected status as a national monument in $2000 .{ }^{359}$ Rehabilitation of the entire building, which can barely be delayed much longer (Fig. 127), is still an open question, although its architectural values are not in any doubt at all. The photographic mural-montage that was created as an integral part of the building is not only a symbolic depiction of certain aspects of the modern way of living - greater spatial awareness, as an experience

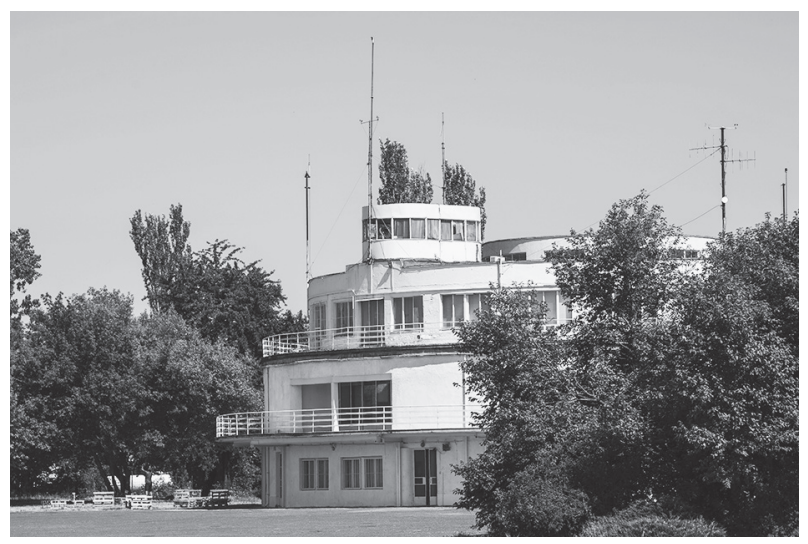

Fig. 127. Budaörs Airport on the eightieth anniversary of the opening of the airport, 20 June 2017

(photo: Zsolt Szigetváry; MTI DSZZS20170620108) 
brought about by modernity, and flight, as the luxury of the modern age -, but also casts it in material form.
Here, the photograph serves both as an object and as a material value. ${ }^{360}$

\section{ABBREVIATIONS}

\section{Archives, institutions, manuscripts}

BFL

BTM Kiscelli Múzeum

FORTEPAN

FSZEK Budapest Gyưjjtemény

HIM

HL

HL Winkler-hagyaték

IPM

KHGy, Budapest XVI.

KMM

KMM Kézirattár

MÉM

MÉM Borbíró-hagyaték

MFM

MKEL

MNL-OL

MNM

MTA BTK MI

MTA BTK MI Adattár

MTA BTK MI Fotótár

MTI

Vintage Galéria
Budapest Fôváros Levéltára / Budapest City Archives

Budapesti Történeti Múzeum, Kiscelli Múzeum / Budapest History Museum, Kiscelli Museum, Budapest

Fortepan online photo archives: http://www.fortepan.hu

Fôvárosi Szabó Ervin Könyvtár, Budapest Gyưjtemény / Metropolitan Ervin Szabó Library, Budapest Collection

Hadtörténeti Intézet és Múzeum / Institute of Military History and Museum, Budapest Hadtörténeti Levéltár / Military History Archives, Budapest

HL Winkler László repüléstörténeti hagyatéka / HL Aviation History Estate of László Winkler, 1926-2001. Personalia. 452-481. doboz. VII. 276.

Iparmûvészeti Múzeum / Museum of Applied Arts, Budapest

Kertvárosi Helytörténeti Gyújtemény, Budapest, XVI. kerület / Local History Collection, $16^{\text {th }}$ District of Budapest

Közlekedési és Múszaki Múzeum / Museum of Transport and Technology, Budapest

KMM Manuscript Archive

Magyar Építészeti Múzeum / Hungarian Museum of Architecture, Budapest

MÉM Bierbauer (Borbíró) Virgil hagyatéka / MÉM Estate of Virgil Bierbauer (Borbíró), Gyarapodási Napló száma: 659. 1-22. doboz

Magyar Fotográfiai Múzeum / Hungarian Museum of Photography, Kecskemét

Magyar Képzômúvészeti Egyetem Levéltára / Archives of the Hungarian University of Fine Arts, Budapest

Magyar Nemzeti Levéltár Országos Levéltára / National Archives of Hungary, Budapest

Magyar Nemzeti Múzeum, Történeti Fényképtár / Hungarian National Museum, Historical Photo Collection, Budapest

Magyar Tudományos Akadémia, Bölcsészettudományi Kutatóközpont, Mủvészettörténeti Intézet / Institute of Art History, Research Centre for the Humanities, Hungarian Academy of Sciences, Budapest

Archives of the MTA BTK Institute of Art History

Photographic Archives of the MTA BTK Institute of Art History

Magyar Távirati Iroda / Hungarian News Agency, Budapest

Vintage Gallery, Budapest

\section{BIBLIOGRAPHY}

ABA-NovÁK 1931 - ABA-NovÁK, Vilmos: Vallomás, Magyar Mũvészet 7. 1931. No 3, 128-136.

ADEs 1986 - ADES, Dawn: Photomontage, London: Thames and Hudson, 1986.

[A ... f ] 1934 - Budapest Székesfôváros Elektromos Mûvei kelenföldi áramfejlesztô telepének újabb építkezései, Tér és Forma 7. 1934. 311- 323.

Albertini 1993 - Albertini, Béla: Vonzások és taszítások. Fotográfiánk és a nagyvilág a húszas évektől a hetvenesekig, Alföld 44. 1993. No 3, 52-60.

Albertini 2003 - Albertini, Béla: A fotószakíró Brogyányi Kálmán, Pozsony: AB-ART, 2003.

[B.] 1937 - [B.]: Olyan, mint egy repülésnek induló sas! Dr. Bierbauer Virgil építészmérnök érdekes nyilatkozata az új budaôrsi repülőtérrổl, A Múszaki Világ 1937. július 3., 2.
BACSKai 1993 - Bacskai, Sándor: Életünk. Dr. Aczél Márta mesél férjérôl Dr. Kreilisheim Györgyrôl, Fotómüvészet 36. 1993. 44-47.

BAJKAY 2005 - BAJKAY, Éva: Egy bauhausler fotói a pécsi vásárokról (Fodor Etel centenáriumára), Jelenkor 48. 2005. 1049-1052.

BAKI 2011 - BAKI, Péter: A fotográfia és a magyar sajtó kapcsolata 1945-ig, PhD-thesis, Budapest: Eötvös Loránd University - Doctoral School of Art History.

Balla-Hrenkó 1991 - Balla, János - Hrenkó, Pál: A magyar katonai térképészet története I, Budapest: HM Térképész Szolgálat Fônökség, 1991.

BAUdin 2005 - Photography, Modern Architecture and Design. The Alberto Sartoris Collection, Objects from the Vitra Design Museum, ed. Baudin, Antoine, Lausanne: EPFL press, 2005. 
BeKE 2009 - BeKE, László: Lajos Kassák: Montage Self-Portrait, in On the Stage of Europe. The millennial contribution of Hungary to the idea of European Community, ed. Marosi, Ernó, Budapest: Research Institute for Art History of the Hungarian Academy of Sciences - Balassi Kiadó, 2009. 312-314

BEKE 2013 - BEKE, László: Múvészet-e a mozdulatmúvészet? - múvelôdéstörténeti szerepek, in Mozdulat - magyar mozdulatmúvészet a korabeli társadalom és müvészet tükrében, eds. BEKE, László - NÉMETH, András - VINCZE, Gabriella, Budapest: Gondolat Kiadó, 2013. 7-14.

BeKe 2000 - Beke, Zsófia: Perspektíva - felülnézet - absztrakció. A kép tere és a tér képe az olasz futurista aeropitturában = Perspetive - Overhead View - Abstraction. The space of the image and the image of space in the Italian Futurist Aeropittura, in Exh. Cat. Budapest 2000, 205-217.

Békeszerződés 1920 - A Magyar Békeszerződés. Kiadja a M. Kir. Külügyminisztérium. Budapest: M. Kir. Tud. Egyetemi Nyomda, 1920.

Benjamin 1936 - Benjamin, Walter: Das Kunstwerk im Zeitalter seiner technischen Reproduzierbarkeit (1936), in Benjamin, Walter: Gesammelte Schriften. Band I.2. Abhandlungen, herausgegeben von TIEDEMANN, Rolf und SCHWEPPENHÄUSER, Hermann, Frankfurt am Main: Suhrkamp Verlag, 1980. 471-508.

BiBó 2011 - ifj. BiBÓ, István: Bibó István levelezése Bierbauer (Borbíró) Virgilnével és családjával (I), Holmi 23. 2011. 939-973.

BierbaUer 1928 - Bierbauer, Virgil: Kelenföld-Rummelsburg, Magyar Mũvészet 4. 1928. 117-131.

Bierbauer 1930 - Bierbauer, Virgil: A Tér és Forma programjáról, Tér és Forma 3. 1930. 342.

Bierbauer 1935 - Bierbauer, Virgil: A kiállítások mủvészete, Magyar Szemle 5. 1935. No 10. 144-145.

BierbaUER 1936 - Bierbauer, Virgil: Repülőtérépítés, Búvár II. 1936. No 15. 142-146.

BierbaUer 1937A - BierbaUer, Virgil: A világ leghíresebb építészeti, múvészei és szakértôii megállapították a modern építészet új irányát. A Volta-kongresszus érdekes vitái és eredményei. 1936. (lecture manuscript, 1937): MÉM Borbíró-hagyaték, GyN. 659. 11. doboz. „14. a. külföldi elôadások 1934-39." téka

BierbaUer 1937B - BierbaUer, Virgil: A fotófreskóról, in Budapest 1937, 224-226.

BierbaUER 1937C - BierbaUer, Virgil: A fotofreskóról, Tükör X. 1937. 732-736.

BierbaUer 1937D - Bierbauer, Virgil: Magyarország repülôgéprôl, Budapest: Officina, 1937.

BierbaUER 1938 - Bierbauer, Virgil: Repülőterek építészete I-II, A Magyar Mérnök- és Építész-Egylet Közlönye 72. 1938. 257-268, 277-283.

Bierbauer-Padanyi 1931 - Bierbauer, Virgil - Padanyi, Gulyás Jenô: 30.000 voltos kapcsolóház a Székesfôváros Elektromos Múvei Kelenföldi telepén. Tervezte: Dr. Ing. Bierbauer Virgil, Tér és Forma 4. 1931. 109-116.

Biro 2013 - Biro, Mathew: Review of The New Women International: Representations in Photography and Film from the 1870s through the 1960s, eds. OTto, Elizabeth Rocco, Vanessa, The University of Michigan Press and The University of Michigan Library, MI, 2011, History of Photography 37. 2013. Summer, 374.
Boni 1962 - Photographic Literature, ed. Boni, Albert, New York: Morgan \& Morgan INC Publishers, 1962.

Borbíró 1948 - Borbíró, Virgil: „Tíz levél az építészetrôl 1948". dosszié, MÉM Borbíró-hagyaték, 12. doboz, „18/a. ép.elm./a." téka

BorbírónÉ, Palackposta - BORBíró, Virgilné: Palackposta [Message in a Bottle] (diary, manuscript), MÉM Borbíró-hagyaték, 15. doboz - sections: I. Amíg összekerültünk (1915-1920) [Before we became one (19151920)], II. A hôskor (1920-1926) [The age of heroism (1920-1926)], III. A nagy hullám (1926-1934) [The great wave (1926-1934)], IV. Hullámvölgy és talpraállás (1934-1942) [Down in the trough and back on one's feet (1934-1942)], V. Mélypont: harctér és ostrom (1942-1945) [The low point: battlefield and siege (1942-1945)], VI. Szélmalomharc a politika utvesztôjében (1946-1949) [Fighting windmills in the labyrinth of politics (1946-1949)], VII. Lassu harc az építészetért és az életért (1949-1956) [The slow struggle for architecture and for life (1949-1956)], VIII. Epilógus, függelék [Epilogue and appendix].

BORECZKY 2013 - BORECZKY, Ágnes: Más mûvészet - új közönség. A mozdulatmúvészet és a korabeli társadalom, in Mozdulat - magyar mozdulatmüvészet a korabeli társadalom és müvészet tükrében, eds. BEKE, László - NÉMETH, András - VinCZE, Gabriella, Budapest: Gondolat Kiadó, 2013. 52-83.

BORTNYIK 1930 - BORTNYIK, Sándor: Az új fotómũvészet, Magyar Grafika XI. 1930. No 9-10. 277-278.

BozóKI 1996 - BozóKI, Lajos: Politika és tudomány. A Mũemlékek Országos Bizottságának megújulása Gerevich Tibor irányítása alatt (1934-1945), in A magyar múemlékvédelem korszakai. Tanulmányok, ed. BARDOLY, István, Budapest: Országos Múemlékvédelmi Hivatal, 1996. 171-189.

BROGYÁNYI 1932 - BROGYÁNYI, Kálmán: A fotográfia útja = Der Weg der Fotografie, Forum 2. 1932. No 4. 111 112, No 7. 178-179, No 8. 209-211.

BROGYÁnyI 1933 - BRogyányi, Kálmán: A fény mũvészete, Pozsony: Forum, 1933 (facsimile edition, with a foreword by Béla Albertini: Pozsony, 2004)

[B.T] 1932 - B.T: A budapesti repülőtér, Aviatika 1932 április, 106-107.

Budapest 1937 - A budapesti új közforgalmi repülótér, Tér és Forma 10. 1937. 207-250.

Budapest 2010 - A félre-értelmezett futurizmus = Helikon Irodalomtudományi Szemle 56. 2010. No 3.

Croy 1939 - Croy, Otto: Fotomontage: Der Weg zu den Grenzen der Fotografie, Halle (Saale): Verlag von Wilhelm Knapp, 1939.

Csengel-Plank 2011 - Csengel-Plank, Ibolya: A Budaörsi közforgalmi repülótér és „A repülés élménye” fotómontázs, Mũemlékvédelem 55. 2011. 304-320.

Csengel-Plank - Hajdú - Ritoók 2003 - Csengel-Plank, Ibolya - Hajdú, Virág - Ritoók, Pál: Fény és Forma. Modern épitészet és fotográfia 1927-1950 / Light and Form. Modern Architecture and Photography in 19271950, Budapest: Kulturális Örökségvédelmi Hivatal, 2003; Budapest: Vince Kiadó , 20112

CsORBA 2000 - E. CsORBA, Csilla: Magyar fotográfusnók 1900-1945, Budapest: Enciklopédia Kiadó, 2000.

[CZ] 1930 - CZ: A légiközlekedés számokban, Aviatika 1930. január, 15. 
CZAPÁRY 1931 - CZAPÁRY, Jenó: Az amerikai repülés mozaikja, Aviatika 1931. január. 11-15.

CZAPÁRY 1932A - CZAPÁRY, Jenô: A jövố repülôterei, Aviatika 1932. március, 80-82.

CZAPÁRY 1932B - CZAPÁRY, Jenô: Az amerikai városok repülótérproblémái, Aviatika 1932. május-június, 158-161.

CZAPÁRY 1932C - CZAPÁRY, Jenô: Amerikai városok repülótérproblémái, Aviatika 1932. július-szeptember, 196199.

DARLING 2012 - Darling, Elizabeth: Wells Coates. Twentieth Century Architects, London: RIBA Enterprises Ltd., 2012.

DÁVID 2010 - DÁvid, Kinga: A futurizmus esztétikája, Helikon (Budapest) 56. 2010. No 3. [A félre-értelmezett futurizmus], 342-359.

DeRCSÉNYI 1980 - DeRCSÉnYI, Dezsô: Gerevich Tibor 1882 1954, Életünk, XVII. 1980. 1081-1090.

Domela Nieuwenhuis 1989 - Domela Nieuwenhuis, Ceasar: Photomontage, in PHILlips 1989, 305-308.

EDWARDS-HART (eds.) 2004 - Photographs Objects Histories: On the Materiality of Images, eds. EDWARDS, Elizabeth HART, Janice, Routledge, 2004.

EGAN 1998 - From the Album of Mollo and Egan, with comments by EGAN, Michael, ... 1998 (the album is mentioned - together with photos from it - by EYLES 1998)

Elischer 1937 - Elischer, Pál: A budapesti repülôtér építésének megszervezése, in Budapest 1937, 210-212.

Evans-Gohl 1986 - Evans, David - Gohl, Sylvia: Photomontage: A Political Weapon, London, 1986.

Exh. Cat. Budapest 1930 - Magyar Könyv- és Reklámmúvészek Társasága bemutatkozó kiállitásának katalógusa az Országos Magyar Iparmüvészeti Múzeumban, (exhibition catalogue), Budapest, 1930

Exh. Cat. Budapest 1981 - Geróné Krámer, Márta et al.: Magyar épitészet a két világháború között. O. M. F. Magyar Épitészeti Múzeumának kiállitása, MÉSZ 1981. október (exhibition catalogue)

Exh. Cat. Budapest 1988 - Mũvészet és forradalom. Oroszszovjet mûvészet 1910-1932, eds. BAKOs, Katalin Havas, Valéria (exhibition catalogue), Budapest: Múcsarnok $1988^{2}$

Exh. Cat. Budapest 1999 - Szép új világ. Modern építészet Skóciában és Magyarországon 1930-1950 / Brave New Worlds. An exhibition of Modern Architecture in Scotland and Hungary in 1930-1950, eds. McKenzIE, Ray, HeRMANSEN, Christian, (exhibition catalogue), Budapest: Országos Mũemlékvédelmi Hivatal, 1999.

Exh. Cat. Budapest 2000 - Perspektiva = Perspective, Volume of symposium studies and exhibition catalogue, Budapest: Múcsarnok - C3, 2000.

Exh. Cat. Cambridge-Boston 1992 - Montage and Modern life 1919-1942, exhibition curators Lavin, Maud [et al.], ed. Teitelbaum, Matthew, (exhibition catalogue), Cambridge-Boston: The MIT Press, 1992.

Exh. Cat. London 1997 - Airport: the most important new buildings of the twentieth-century, ed. BODE, Steven, London: Photographers' Gallery, 1997.

Exh. Cat. London 2007 - Foto Modernity in Central Europe 19181945, ed. WitkovszkY, Matthew S., exhibition catalogue, National Gallery of Art, Washington, June 10-September 3. 2007. London: Thames and Hudson, 2007.
Exh. Cat. New York 1969 - American Art of the 20's and 30's. Murals by American Painters and Photographers, eds. KIRSTEIN, Lincoln - LEVY, Julien (exhibition catalogue), New York: The Museum of Modern Art, 1969.

Exh. Cat. Stuttgart 1929 - Film und Foto. Internationale Ausstellung des Deutschen Werkbundes, Stuttgart, Deutsche Verlags-Anstalt, 1929.

EYLES 1998 - EyLES, Allen: Meeting Michael Egan. An Interior Designer's Work, Picture House 1998. No 23, Summer, 3-19.

FEHÉRVÁRI 1987 - FEHÉRVÁRI, Zoltán: Borbiró Virgil (18931956) építészeti tevékenysége, magisterial thesis (manuscript), Eötvös Loránd University, Faculty of Humanities, Department of Art History, Budapest, 1987.

FEHÉRVÁRI-PRAKFALVI 2006 - FeHÉRVÁRI, Zoltán - PrakFalvi, Endre: A Ferihegyi repülôtér 1. termináljának építése, in Modern és szocreál. Épitészet és tervezés Magyarországon 1945-1959, eds. FeHÉRvári, Zoltán - Hajdú, Virág - PrakFalVI, Endre, Budapest: Magyar Építészeti Múzeum, 2006. 19-34.

FERKAI 1999 - FerKaI, András: Modernizmus a magyar építészetben, in Szép Új Világ - Modern épitészet Skóciában és Magyarországon 1930-1950 (Szép Új Világ vándorkiállítás, Glasgow School of Art, Mackintosh Museum 1999. március 1-13., Országos Múemlékvédelmi Hivatal, 1999. április 18. - június 13.), eds. McKenZIE, Ray and Hermansen, Christian, Budapest, 1999. 12-15.

FERKAI 2011 - FERKAI, András: Molnár Farkas, Budapest: Terc Kiadó, 2011

FERKAI 2012 - FERKAI, András: Az árumintavásár és a modern építészet, in Opus Mixtum 1: A CentrArt Egyesület évkönyve, ed. SzÉKely, Miklós, Budapest: CentrArt Egyesület, 2012. 92-99. - http://issuu.com/centrart/ docs/opus_mixtum_1

FISCHER 1942 - FISCHER, József: Élet és reprezentáció, Tér és Forma 15. 1942. 102-113.

Fogu 2005 - Fogu, Claudio: To Make History Present (The Fascist Historic Imaginary on Exhibit), in Cornell Donatello among the Blackshirts. History and Modernity in the Visual Culture of Fascist Italy, eds. LAzzARO, Claudia GRUM, Roger J., Ithaca and London: Cornell University Press, 2005. 33-49.

FRAMPTON 2009 - FRAMPTON, Kenneth: A modern épitészet kritikai története, Budapest: Terc Kiadó, $2009^{2}$

FREUnd 1976 - Freund, Giselè: Photographie und Gesellschaft, München: Rogner und Bernhard, 1976.

FRISNYÁK 2001 - FRISNYÁK, Zsuzsa: A magyarországi közlekedés krónikája 1750-2000, Budapest: História - MTA Történettudományi Intézete, 2001.

GENTHON 1925 - GentHON Isván: Merz és fotoplasztika, Magyar Írás 1925. No 6, 87-88; újraközölve: Fotografozásról, ed. BÁN, András, Budapest: Múzsák Közmûvelődési Kiadó, 1982. 204-205.

G.M. 1935 - G. M.: Kiállítást rendeznek az olaszok! (Az 1934. évi milánói aeronautikai kiállítás), Tér és Forma 8. 1935. 179-184

Golan 2009 - Golan, Romy: Muralnomad. The Paradox of Wall Painting Europe 1927-1957, New Haven - London: Yale University Press, 2009.

GORDON 2008 - GORDON, Alistar: Naked Airport. A Cultural History of the World's Most Revolutionary Structure, Chicago and London: The University of Chicago Press, 2008. 
HAFFner 2013 - Haffner, Jeanne: The View from Above: The Science of Social Space, Cambridge: MIT Press, 2013.

Harper Collins Dictionary 1991 - The Harper Collins Dictionary of Art Terms and Techniques, Second Edition, ed. MAYER, Ralf, New York: Harper Perennial, 1991.

HAUSMANN 1931 - HAUSMANN, Raoul: Photomontage, in a bis $z$ (Cologne), May 1931; excerpt reprinted in PHILLIPS 1989. 178-181.

Herczeg 1982 - Herczeg, Károly: Légikikötôk, Budapest: Múszaki Könyvkiadó, 1982

Hültl 1931A - Hültl, Hümér: Szüksége van-e Budapestnek új forgalmi repülőtérre? Aviatika 1931. január, 17-20.

Hültl 1931B - Hültl, Hümér: A budapesti repülôtér elhelyezése, Aviatika 1931. május, 180-185.

Hültl 1937 - Hültl, Hümér: A légiforgalom jelentősége, in Magyarország közlekedésügye 1937, Budapest: Pallas Rt., 1937. 279-286.

JONGE 1991 - JONGE, Wessel de: A modern mozgalom örökségének megőrzése, Mũemlékvédelem 35. 1991. 16-17.

KARÁDY 1994 - KARÁDY, Viktor: A társadalmi egyenlőtlenségek Magyarországon a nốk felsôbb iskoláztatásának korai fázisában, in Férfuralom. Írások nökrôl, férfiakról, feminizmusról, ed. HADAS, József, Budapest: Replika Kör, 1994. 176-195.

KASSÁK 1930 - KASSÁK, Lajos: Fotómontázs, in A Magyar Könyv-és Reklámmũvészek Társasága bemutatkozó kiállításának katalógusa, Országos Magyar Iparmủvészeti Múzeum, Budapest, 1930. április 12-27., 6-12.

KASSÁK 1999 - KASSÁK, Lajos: Reklám és modern tipográfia. Írások, képek, ed. CSAPLÁR, Ferenc, Budapest: Kassák Lajos Emlékmúzeum és Archívum, 1999.

[K.H.] 1937 - [K.H.] A budapesti repülötér forgalmi épülete, in Budapest 1937. 213-224.

KieSLER 1936 - KIESLER, Frederick J.: Murals without Walls. Relating to Gorky's Newark Project, Art Front 2. December, 18. 1936. 10-11. (reprinted in Bowman, Ruth: Murals without Walls: Arshile Gorky's Aviation Murals Rediscovered. Newark Museum, 1978. 30-33)

Kiliász 1930 - Kiliász: Milyen a jó repülőtér? Aviatika 1930. március, 60-65.

[K.M] 1937 - [K.M] [=BIERBAUER Virgil]: Építészet-szobrászat-festészet, Vállalkozók Lapja 1937. január 14., 4.

[K.M] 1938 - [K.M]: Séta a készülô Vásár-városban, Vállalkozók Lapja 1938. április. 27., 5.

Kolta 2003 - Kolta, Magdolna: Képmutogatók. A fotográfiai látás kultúrtörténete, Kecskemét: Magyar Fotográfiai Múzeum, 2003.

Komor 1928 - Komor, János: Közlekedési épületek, Tér és Forma 1. 1928. 153-158.

Kosztolányi 1931 - KosztolánYi, Dezső: Nyolcvan ismeretlen fénykép, Pesti Hírlap 1931. február 8., 5.

KovÁCs 1996 - Kovács, Ákos: Feszty Árpád és a körkép, Ars Hungarica 24. 1996. 87-103.

Kovács 1997 - Kovács, Ákos: Két körkép, Budapest: Sík Kiadó, 1997.

Kozma 1938 - Kozma, Lajos: Budapest légikikötôje. Tervezték: dr. Bierbauer Virgil és Králik László, Magyar Mũvészet 14. 1938. No 6. 177-181.

KREILSHEIM 1941 - KREILSHEIM György: A régi magyar fényképezés, Budapest, 1941.
KrEILSHEIM 1998 - KREILSHEIM György: Régi magyar fényképezés - A fotográfia regénye, Budapest: Vintage Galéria, 1998.

La Hongrie 1937 - La Hongrie a l'Exposition Internationale de Paris, publié par le Commissaire Général du Gouvernement Hongrois près l'Exposition Internationale de Paris, Budapest: Pallas, 1937

Le Corbusier 1935 - Le Corbusier: Aircraft (The New Vision), New York: Published by The Studio Ltd., 1935.

Le Corbusier 1981 - Le Corbusier: Új épitészet felé, Budapest: Corvina Kiadó: 1981. (English-language version: Towards a New Architecture. Translated from the 13th French edition, New York: Payson \& Clarke, 1927)

LENKEI 2009 - LENKEI, Júlia: Egy analitikus a mozdulatmúvészek között. P. Liebermann Lucy pályaképében, Thalassza 20. 2009. No 1. 93-94.

Lista 2001 - LisTA, Giovanni: Futurism and Photography, London: Merrell in association with Estorick Collection of Modern Italian Art, 2001.

LODDER 2004 - LODDER, Christina: Malevich, Suprematism and Aerial Photography, History of Photography 28. 2004. Spring, 25-40

LuCIE-Smith 2000 - Lucie-Smith, Edward: XX. századi müvészek élete, Budapest: Glória, 2000. (original edition: Lives of the Great 20th-century Artists, London: Thames \& Hudson, 1999)

MADARÁsz 1925 - MadARÁsz, László: A levegô meghódítása, Budapest, 1925

MAJdÁn 2014 - MAjDÁN, János: A közlekedés története Magyarországon (1700-2000), Pécs: Pro Pannonia, 2014. (Pannónia könyvek)

MarinetTi 1909 - MarinetTi, Filippo Tomaso: Fondazione e Manifesto del Futurismo, Le Figaro 1909. 02. 20.

Marinetti 1973 - Marinetti e il futurismo, ed. DE MARIA, Luciano, Milano: Mondadori, 1973

MARKÓJA - BARDOLY (eds) 2009 - Római iskola, eds. MARKÓJA, Csilla - BARdoly, István, Enigma XVI. 2009. No 59.

Mezei 1979 - Mezei József: Az adott világ varázsainak mérnöke, in Moholy-Nagy, László: A festéktöl a fényig, összeállította és jegyzetekkel ellátta SugÁr, Erzsébet. Bukarest: Kriterion Könyvkiadó, 1979. 5-42.

Mezer 1981 - Mezei, Ottó: A Bauhaus magyar vonatkozásai: elôzmények, együttmüködés és kisugárzás, Budapest: Népmúvelési Intézet és Művelôdéskutató Intézet, 1981.

Moholy-Nagy 1925 - Moholy-Nagy, László: Malerei, Fotografie, Film, Bauhausbücher 8. Munich: Langen, 1925.

Moholy-Nagy 1928 - Moholy-NAgy, László: Fotografie ist Lichtgestaltung, Bauhaus, Zeitschrift für Gestaltung 2. 1928. No. 1 (reprinted in Hungarian in PASsUTH 1982. 306-308).

Moholy-Nagy 1929 - Moholy-Nagy, László: Von Material zu Architektur, Bauhausbücher 14. Munich: Langen, 1929.

Moholy-Nagy 1933 - Moholy-NAgy, László: A fotográfia: napjaink objektív látási formája, Korunk 8. 1933. No 12, 911-913.

Moholy-Nagy 1947 - Moholy-Nagy, László: Vision in Motion, Chicago: Paul Theobald Company, 1947

Moholy-Nagy 1972 - Moholy-Nagy, László: Az anyagtól az épitészetig, Budapest: Corvina, 1972 (first edition: MoHoly-NagY 1929). 
Moholy-Nagy 1978 - Moholy-Nagy, László: Festészet, fényképészet, film, Budapest: Corvina, 1978. (first edition: Moholy-Nagy 1925)

Molnár 1928 - MolnÁr, Farkas: A racionális építkezésrôl, Tér és Forma 1. 1928. 198-199.

Molnár 1931 - Molnár, Farkas: A fotomontázsról, Magyar Iparmüvészet 34. 1931. No 3-4. 69-70.

MolnÁR 1934 - Molnár, Farkas: Az Új Építészet eredményeinek és célkitũzéseinek összefoglalása, Városkultúra (Szeged) 1934. No 1. 18-20; No 2. 34-36 (reprinted in: Épités- Épitészettudomány 27. 1998. 171-178.

Molnár C. 1941 - Molnár C., Pál: Monumentális festészet (falképfestés, mozaik, üvegfestészet), in A képzômüvészet iskolája, ed. SzÔNYI, István, Budapest: Gyôzô Andor kiadása, 1941. 143-188.

Molnos 2009 - Molnos, Péter: Újrafestve. Gerevich Tibor és Aba-Novák Vilmos, Enigma No 59, XVI. 2009. 5-36.

MORAVÁNSZKY 2000 - MorAVÁNSZKY, Ákos: Az axonometria mint szimbolikus forma, in Exh. Cat. Budapest 2000, 200-201.

Móricz 1936 - Móricz, Zsigmond: Fény-Gyár, Az Est 1936. november 27., 10

Mughini 2000 - Mughini, Giampiero: Il manifesto e l'aeronautica, in Manifesti e dipinti dul volo in Italia 1908-1943, a cura di Scudiero, Maurizio - Cirulli, Massimo, New York: Publicity and Print Press, 2000. 13-30.

Murals 1932 - Murals by American Painters and Photographers, New York, 1932.

NAegele 1998 - NAEgele, Daniel: Le Corbusier and the Space of Photography. Photo-murals, Pavilions and Multi-media Spectacles, History of Photography 22. June 1998. 127-138.

NAGy 1941 - Nagy, Zoltán: Új magyar mũvészet. Száz év szobrászata és festészete, Budapest: Athenaeum Irodalmi és Nyomdai R.-T, 1941.

NAHÓCZKY 2010 - NAHÓcZKY, Judit: A futurizmus recepciójának néhány kérdése a centenáriumi kiállítások tükrében, Helikon (Budapest) 56. 2010. No 3. [A félreértelmezett futurizmus], 459-464.

New technique 1932 - A new technique of cinema lighting. Designed by Eugene Mollo, The Architecture Review Supplement, 1932. Number 28. 216-217.

NeWHall 1980 - Photography: Essays E Images, ed. NeWHall, Beaumont, New York: The Museum of Modern Art, 1980.

ORDASI 2004 - ORDASI, Zsuzsa: „Mussolininek mindig igaza van”. A modern építészet néhány kérdése Mussolini Olaszországában, Limes 2004. No 1, 29-36. http://www.jamk.hu/ek/folyoirat/folyoirat/art_ limes/2004_1.pdf

ORDASI 2007 - ORDASI, Zsuzsa: A mozgás állomásai: Faludi Jenô római reptér terve, Régi-Új Magyar Épitömũvészet 2007. No 2. 48.

ORDASI 2010 - ORDASI, Zsuzsanna: Architettura e architetti italiani nella stampa ungerese (1890-1945), in Dibattito internazionale e realta locali. L'altra modernita nella cultura architettonica del XX secolo, a cura di NeRI, Maria Luisa, Rome: Gangemi Editore. 2010. 57-86.

Отто 2005 - Отто, Elizabeth: Tempo, tempo! Bauhaus - Photomontagen von - The Bauhaus Photomontage of Marianne Brandt, Berlin, Bauhaus Archive Berlin, 2005.
Overy 2007 - Overy, Paul: Light, Air and Openness. Modern Architecture between the Wars, London: Thames and Hudson, 2007.

Passuth 1982 - Passuth, Krisztina: Moholy-Nagy László, Budapest: Corvina, 1982

PÉCSI 1930A - PÉCSI, József: Fotó és reklám, Magyar Grafika XI. 1930. 75-79.

PÉCSI 1930B - PÉCSI, József: Photo und Publizität / Photo and Advertising, Berlin: A. J. Singer S. A., 1930. [new edition: Basel, 1989]

PÉCSI 1930C - PÉCSI, József: Fotó és reklám, Magyar Grafika XI. 1930. 257-262.

PÉCSI 1997 - PÉCSI, József: Fotó és reklám: szöveg és kép: Pécsi József, a fotográfia professzora [reprint], Budapest: Intera Könyvkiadó, 1997.

Perloff 1986 - Perloff, Marjorie: The Futurist Moment: Avant-garde, Avant Guerre, and the Language of Rupture, Chicago: University of Chicago Press, 1986.

Peternák 2002 - Peternák, Miklós: A Magyar Képzômúvészeti Egyetem Könyvtárának optikával, perspektívával, érzékeléssel, mozgásillúzióval kapcsolatos tárgyi emlékei, dokumentumai, in A Mintarajztanodától a Képzôművészeti Fôiskoláig, Budapest: Magyar Képzômúvészeti Egyetem, 2002.

Petróczy 1922 - Petróczy, István: Nemzetközi repülőtér nélkül életképtelen a magyar aviatika, Az Aëro IX. 1922. No 14. 142.

Phillips 1989 - Photography in the Modern Era: European Documents and Critical Writings, 1913-1940, ed. by and. intr. Phillips, Christopher, New York: The Metropolitan Museum of Art, 1989.

Photo-mural 1937 - The True Photo-mural a New Technique of Decoration, Decoration the Architectural Review Supplement, Architectural Review February 1937. 85-88.

Prakfalvi 1992 - Prakfalvi, Endre: Elmélet és gyakorlat építészetünkben, 1945-1956, in Épitészet és tervezés Magyarországon 1945-1956 / Architecture and planning in Hungary 1945-1956, Budapest: OMvH Magyar Építészeti Múzeum, 1992. 7-23.

Prakfalvi-SzúCs 2010 - PraKFalvi, Endre - SzưCS, György: A szocreál Magyarországon, Budapest: Corvina Kiadó, 2010.

RÉv 1980 - RÉV, Pál: Az elsổ közforgalmi vállalatunkról, Közlekedéstudományi Szemle 30. 1980. No 5. 221-224.

RÉV 1988 - RÉv, Pál: A budaörsi közforgalmú repülőtér létesítésének története, in Közlekedési Múzeum Évkönyve 8. 1988. (Közlekedési tanulmányok II.) 503-525.

RÉVÉSZ-BIRÓ 1931 - RÉVÉsz, Imre - BIRÓ, Pálma: Photo-reklám, Budapest: Pallas, 1931.

Ribalta 2008 - Public Photographic Space Exhibitions of Propaganda, from "Pressa" to "The Family of Man," 1928-55, ed. Ribalta, Jorge, Barcelona: Museu d'Art Contemporani de Barcelona, 2008.

[rl] 1936 - [rl]: Az építészet jövôje, Tér és Forma 9. 1936. $119-126$.

RoH 1929 - RoH, Franz: Mechanism and Expression: the Essence and Value of Photogaphy. Introduction to FotoAuge, in RoH-Tschichold 1929, 3-18.

RoH-Tschichold 1929 - Foto-Auge. 76 Fotos der Zeit, zusammengestellt von RoH, Franz - Tschichold, Jan, Stuttgart: Akademischer Verlag, 1929.

ROSNER (ed.) 1939 - Magyar fényképezés = Photographies hongroise $=$ Hungarian photography $=$ Das ungarische Licht- 
bild, ed. Rosner, Károly, London: B. T. Batsford, Ltd. - Budapest: Officina, 1939.

Schulz 1934 - Schulz, Ervin: A fotómontázs, Fotóélet IV. 1934. No 10. 150-151, No 11. 170-171.

Sillay 1930 - Sillay, Aladár: A légi közlekedés nemzetközi jogi szabályozása, in Magyar Aviatikai Évkönyv 1929, Budapest: Wodianer F. és Fiai Grafikai Intézet és Kiadóvállalat R.T. Könyv- és Hirlapnyomdája, 1930. 163-172.

SiNKÓ 2012/1988 - SinKÓ, Katalin: Az optikai teremutazástól a lakótelepi édenig, in: SinKó, Katalin: Ideák, motívumok, kánonok. Tanulmányok a 19-20. századi képkultúra körébốl, Budapest: Magyar Nemzeti Galéria, 2012. 222227. (first published in 1988)

Sipos 2013 - Sipos, Balázs: Világ-képek, kulturális regiszterek és Amerika jelenléte a Horthy-korszakban, Nyitott/Zárt Magyarország. Politikai és kulturális orientáció 1914-1949, ed. Feitl, István, Budapest: Napvilág Kiadó, 2013. 151-183.

SiUKONEN 2001 - SiUKONEN, Jyrki: Uplifted Spirits, Earthbound Machines. Studies on Artis and the Dream of Flight 1900-1935, Helsinki: Finnish Literature Society, 2001.

Soulages 2011 - Soulages, Francois: A fotográfia esztétikája, Budapest: Kijárat Kiadó, 2011. (eredeti kiadása: Esthétique de la photographie : la perte et le reste, Paris: Nathan, 1998)

Spáczay 1971 - Spáczay, Hedvig: A Honvédelmi Minisztérium szervezeti változásai a Horthy-korszakban I. (19191935), Levéltári Szemle 21. 1971. Nos 1-3. 41-78.

Stiller 2000 - Stiller, Adolph: Oswald Haerdtl - Architekt und Designer 1899-1959, Salzburg: Pustet, 2000.

StÜHlinger 2012 - Stühlinger, Harad R.: Photographed Buildings on When Architectural Photography Conquered Architecture, in PhotoResearcher. ESHPh European Society for the History of Photography No 18/2012, 20-31. - http://www.donau-uni.ac.at/imperia/md/ images/studium/kultur/eshph/phrs18_cover_front.pdf

SuPKA 2008 - SuPKA, Magdolna: A Pannó-Aba-Novák Vilmos monumentális alkotása, Budapest: Holnap Kiadó, 2008.

SZEgedy-Maszák 2004 - Szegedy-Maszák, Andrew: Alfred Stieglitz's "The Aeroplane," History of Photography 28. 2004. Spring, 41-42.

SZKÁROSI 2010 - SZKÁROSI, Endre: Elmúlt-e a futurizmus? Az irányzat recepciójának problémái, Helikon 56. 2010. 309-320.

Szứcs 1988 - Szứcs, György: A Vigilia beszélgetése Dercsényi Dezsôvel, Vigilia 53. 1988. No 2. 130-134.

TAKÁTS 2007 - TAKÁTS, László: 70 éves a budaörsi repülôtér, Budapest: Goldtimer Alapítvány, 2007.

Teitelbaum 1992 - Montage and Modern Life, 1919-1942, ed. Teitelbaum, Matthew, Cambridge, MA: MIT Press, 1992.
TÖRÖK 1937 - TÖRÖK, István: A budapesti új közforgalmi repülótér, in Magyarország Közlekedésügye 1937, ed. Dr. PÁrtos, Szilárd, Budapest: Pallas Bt, 1937. 286-291.

TUPITSYN 1999 - TuPITSYN, Margarita, with contributions by DRutT, Matthew and Puhlmann, Ulrich: El Lissitzky beyond the Abstract Cabinet: Photography, Design, Collaboration, Museum d'Art Contemporani de Barcelona, New Haven - London: Yale University Press, 1999

Udovicki-Selb 1997 - Udovicki-Selb, Danilo: Le Corbusier and the Paris Exhibition of 1937. The Temps Nouveaux Pavilon, JSAH Journal of the Society of Architectural Historians 66. 1997. 42-63.

VÁmos 2013 - VÁmos, Dominika: A gyôri programtól a hároméves tervig. A modern magyar ipari építészet születésének gazdaságpolitikai és hivatástörténeti összefüggéseiről, Régi-új Magyar Építômûvészet 2013. No 8. 24-29.

VÁRKONYI 1947 - VÁRKONYI, Zoltán: Fotó a haladás vonalán, Tér és Forma 20. 1947. 3.

WanAVERBECQ-Morocz 2004 - WANAVERBECQ, Annie-Laure - Morocz, Csaba: Photographies hongroises 1919-1939, Regards nouveaux / Az Új Tekintet, Paris: Somogy Editions D'Art, 2004

Warner Marien 2010 - Warner Marien, Mary: Photography: A Cultural History, London: Laurence King, 2010 (3rd Edition)

Wells 1997 - Photography: A Critical Introduction, ed. Wells, Liz, London and New York, 1997.

WiLk (ed.) 2006 - Modernism Designing a New World 1914 1939, ed. WiLk, Christopher, London: V\&A Publications, 2006

WiNKLER 1988 - WinkLER, László: Amiről a Budaörsi repülôtér 50 éve mesél, in MALÉV Repülés és Üzemtörténeti Kör 13. konferencia, Boglárlelle, 1988. nov. 25-27., 1-16.

WinkLer 1996 - WinkLeR, László: A Mátyásföldi repülôtér története, in Corvin Hirnök. 80 éves Mátyásföld repülötér, Budapest: Corvin Múvelődési Ház, 1996.

WinkLer, Magyar Légiforgalmi - WinkLer, László: A Magyar Légiforgalmi Rt. története 1928-tól 1945-ig (manuscript): HL Winkler-hagyaték, 456. doboz.

Wood 2004 - Wood, Andrew F.: New York's 1939-1940 World's Fair (Postcard History Series), Charleston SC: Arcadia, 2004

ZuKowsksi 1996 - Zukowsksi, John: Building for Air Travel: Architecture and Design for Commercial Aviation, ed. ZukOWSKsi, John, with essays by Bosma, Koos ... [et al.], Munich - New York - Chicago: Prestel - Art Institute of Chicago, 1996.

ZwickL 1999 - ZwickL András: A korszerú reprezentáció kísérlete - a római iskola, in ANDRÁSI, Gábor - PATAKI, Gábor - SzÜCs, György - ZwICKL, András: Magyar képzômüvészet a 20. században, Budapest: Corvina Kiadó, 1999. 96-101.

\section{NOTES}

${ }^{1}$ This paper is based on my doctoral dissertation I defended in 2015 (University of Pécs, Faculty of Humanities, Doctoral School of Literature, Doctoral Program in Cultural History). I am indebted to my friends, colleagues and my husband for their encouragement and perceptive sugges- tions: György Kunár † flight historian, Márta Molnár librarian (Hungarian University of Fine Arts, Budapest), Sándor Kiss PhD painter, Zita Nagy photo historian (Ervin Szabó Library, Budapest Collection), Zsuzsanna Ordasi PhD architecture historian (Eötvös Loránd University, Faculty of 
Humanities, Budapest), Dr. Péter Csengel, Dr. Zsolt Szíjjártó historian (University of Pécs), Dr. Pál Lóvei (Hungarian Academy of Sciences, Institute of Art History), Herald R. Stühlinger architect (Zürich), James Dawn researcher (London), Robert Elwall $\dagger$ (Royal Institution British Architecture, London), Antoine Baudin (The Alberto Sartoris Collection, Lausanne), Olga Granasztói PhD literary historian, Andrew Somogyi photographer, András Ágh photographer, István Losonczy teacher of English. I wish to thank the members of the full former staff from Hungarian Museum of Architecture (Budapest): Zoltán Fehérvári, András Hadik, Virág Hajdú, Endre Prakfalvi, Pál Ritoók. I am also very grateful to my teachers and supervisors, in particular to Dr. László Beke (Hungarian Academy of Sciences, Institute of Art History), and Dr. Béla Albertini photo historian. Finally, special thanks to my external readers, Dr. András Ferkai (MoholyNagy University of Art and Design, Budapest), and Dr. Zoltán Fejôs (Budapest), for their valuable critical remarks.

${ }^{2}$ A parlamenti tudósítás folytatása. A kereskedelmi miniszter beszéde az ipari minisztérium szükségességérôl és idôszerûségérôl, Budapesti Hírlap 1935. május 18., 2.

${ }^{3}$ For more about what was prohibited under the terms of the treaty, see: Békeszerzódés 1920; MADARÁsz 1925, 261; SiLlay 1930.

${ }^{4}$ Founding assembly: 19 November 1922: FRISNYÁK 2001, 159

${ }^{5}$ Founding assembly: 8 January 1923: FRISNYÁK 2001, 160.

6 Winkler 1996, 19.

${ }^{7}$ Petróczy 1922, 142; MAEFORT launched a postal service from Albertfalva to Szeged and then to Szombathely: RÉv 1980, 221-224.

${ }^{8}$ Among the sites examined before 1933 was the island of Csepel, which remained in the running for a long while by virtue of being suitable for both land and water traffic: [B.T] 1932, 107.

9 HÜltl 1937, 279-286.

10 Majdán 2014, 131.

${ }^{11}$ Hültl 1931A.

12 Hültl 1937, 279-286.

${ }^{13}$ It was here that the "little entente" countries officially recognised Hungary's right to arm itself, in consequence of which military pilots were excused from their disguised service at civil airports and reassigned to the air force. See: WinkLer, Magyar Légiforgalmi; Budapest 1937, 209-212.

${ }^{14}$ Budapest 1937, 208.

15 [CZ] 1930; Az amerikai repülés mozaikja, Aviatika 1931. január 11-14.; CZAPÁRY 1932B; CZAPÁRY 1932C; HültL 1931A; The criteria for choosing a location were published in 1930 (KILIÁsz 1930), while in 1932 a comparison of the connection between the technical development of aircraft and air traffic was produced by Jenô Czapáry, who was very familiar with American airports and with the situation in America (CZAPÁRY 1932A). See also: Hümér Hültl's lectures on airport architecture from the 1930s: KMM Kézirattár 733/973.

${ }^{16}$ György Endresz and Sándor Magyar were the fifteenth to fly across the Atlantic in a modern Lockheed Sirius 470 LE-s modified for the flight. During the preparation for the flight, not only the Hungarian-American aviation connections gained strength but it was also meant to domestically promote flying.

17 Hültl 1931A; Hültl 1931B.
${ }^{18}$ Minisztertanácsi jegyzôkönyvek [Records of the ministerial council]: MNL-OL, K. 27-1935. IV. 11.

${ }^{19}$ WinkLer 1988, without notes! See also the manuscript of the article: HL Winkler-hagyaték, 455-456. doboz.

${ }^{20}$ The call for airport designs announced as part of the major competition organised by the Hungarian Union of Engineers and Architects in 1934-35 was eventually unsuccessful. There was not even a public announcement of the results, as the evaluating committee (consisting of Gyula Wälder, Hümér Hültl Jr, Lajos Rotter, Sándor Misley, Pál Müller and Jenô Padányi Gulyás) deemed none of the submissions worthy of a prize. The requirements for the terminal building contained many important criteria, including its dual function as a place for dealing effectively with passengers and as a place for an entertaining day out. See: A Magyar Mérnök-és Építész-Egylet Közlönye 68. 1934. 187; 69. 1935. 184.

${ }^{21}$ Vállalkozók Lapja 1936. február 19., 13; the competition was presumably extended, because the periodical later gives the date for publishing the winners of the airport competition as 15 April: Vállalkozók Lapja 1936. május 12., 12; See also the bulletins of Magyar Távirati Iroda (Hungarian Telegraphic Office Hungarian News Agency) on the call for designs for a civil airport to be built on the outskirts of Budaörs: MTI Kônyomatos Hírek 1936. február 14. 17 óra 55 perc: http://mol.arcanum.hu/mti/opt/al00929.htm?v=pdf\& $\mathrm{q}=\mathrm{WRD} \% 3 \mathrm{D} \% 28 \mathrm{rep} \% \mathrm{FCl} \% \mathrm{u} 0151 \mathrm{t} \% \mathrm{E} 9 \mathrm{r} \% 29 \& \mathrm{~s}=$ SORT\& $\mathrm{m}=581 \& \mathrm{a}=\mathrm{rec}$

${ }^{22}$ The Ministry of Defence underwent substantial structural reforms in 1935. The secret division known as the Aviation Office was disbanded, and all the technical matters to do with architecture and urban planning came under the scope of the Ministry of Industry, while transport architecture and state buildings were transferred to the transport portfolio. This explains why both these ministries are mentioned in connection with the construction of Budaörs Airport. See: SPÁCZAY 1971, 60-77.

${ }^{23}$ László Czakó won the competition to design the new airport in Budapest: Vállalkozók Lapja 1936. május 12., 12; According to a report by a member of the National Art and Literature Council, Dr Virgil Bierbauer's design was recommended for purchase as the second-place entrant, and László Králik featured among the recipients of the second prize: letter from Guidó Hoeppfner to the chairman of the National Art and Literature Council, Dr Gábor Ugron, former minister of the interior, Budapest 10 June 1936: MTA BTK MI Adattár, MDK-C-I-1/5097.

${ }^{24}$ ELISCHER 1937, 211.

25 Bierbauer 1938, 282.

26 VÁmos 2013, 25-28.

27 ORdasi 2010, 121-149.

${ }^{28}$ IV. Congresso Internazionale di Navigazione Aerea, Roma, 24-30 October 1927: Faludi gave a presentation titled "Il problema degli aeroporti civili."

${ }^{29}$ KOMOR 1928, 153-158.

30 ORDASI 2007, 48.

${ }^{31}$ FRAMPTON 2009, 268-274.

32 Molnár 1934; The problem with the history of modern functionalism, in that it was fundamentally incapable of satisfying the needs of the masses and collective desires, was not unique to Hungary. The idealistic nature of the objectives of modernism was discussed at the 8th CIAM Congress in 1952: FRAMPTON 2009, 295. 


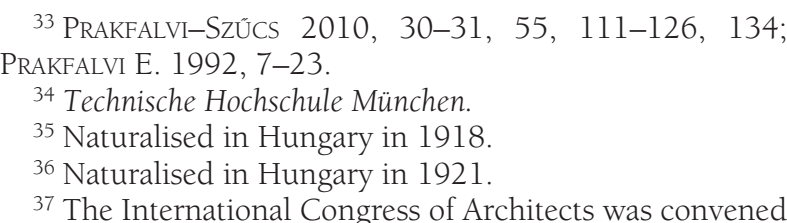
every three years by the Comité Permanent International des Architects (CPIA).

38 BORBíRÓnÉ, Palackposta III. (1926-1934), 185.

${ }^{39}$ Vállalkozók Lapja, 1931. június 24., 4.

${ }^{40}$ For more about the activities of Coates, and the building, see: DARLING 2012.

${ }^{41}$ BorbírónÉ, Palackposta III. (1926-1934), 232.

42 Bierbauer 1937C.

43 FEHÉRVÁRI 1987, 57-64.

${ }^{44}$ In the last ten years of his life, Virgil Borbíró served in the following state positions: 1 May 1945-15 March 1947. Újjáépítési Kormánybiztosság [Government Commission for Reconstruction]; 15 March 1947-15 March 1949. Építésügyi Minisztérium [Ministry of Construction]; 20 February 1949-1 October 1950. Képzômúvészeti Fôiskola (College of Fine Arts); 1 August 1949-15 December 1954. Lakásépítô Tervezô Intézet [Institute for Housing Design]. In January 1950 he and three other architects (Frigyes Pogány, József Csemegi Jr and György Kardos) were invited by the Ministry for Construction and Public Works to devise a working plan for reforming architecture: MÉM Borbíró-hagyaték, 7. doboz. "T." 45. levél, "P." 28. levél.

45 Borbíró 1948: Letter 1, to Máté Major; letter 2, to György Kardos; letter 3, to Ervin Schöner; letter 4, "To a journalist": "On the artistic sense of a work of architecture"; letter 6, to Jenô Kismarty Lechner; letter 7, "To a politician"; letter 8, to István Janáky; letter 9, "To an architect in Italy". (Letters 5 and 10 are missing from the dossier.)

${ }^{46}$ Budapest, 6 April 1948. All we know about the recipient of the letter is that it was intended for a journalist: "On behalf of your newspaper you turned to me, asking me to define the most essential problems facing architecture right now, in the present social circumstances."

${ }^{47}$ These were first listed in 1993 by the art historian Anna Kaiser, formerly of the Hungarian Museum of Architecture, who preserved the original folders and system of references.

48 All four photomontages are laminated silver gelatin prints mounted on card: 1 measures $26.5 \times 15 \mathrm{~cm}$, another measures $27 \times 15 \mathrm{~cm}$, and two others measure $28 \times 14.7 \mathrm{~cm}$.

${ }^{49}$ Borbíróné, Palackposta III. (1926-1934), 171.

50 Bierbauer 1934, 315.

${ }^{51}$ Presentation delivered at the request of István Janáky, around 1956: MÉM Borbíró-hagyaték, 11. doboz. "14. hazaiak. B. 1933-56." téka.

52 The City Centre substation converted electricity received from the Kelenföld site into $2 \times 135$ volt direct current, which was then delivered via cable straight to the consumers. The transformer station on Hungária Boulevard converted the 30,000-volt current received via cable from the Kelenföld site into 10,000-volt and 5000-volt currents, which were then converted into direct current at the transformer station on Murányi Street: Az Elektromos Múvek építkezései. A "Belváros" alállomás és a Hungária-köruti transzformátor állomás, Új Budapest, 1930. augusztus 23., 2.

53 [A ... f ] 1934, 322.

${ }^{54}$ Bierbauer-PADANYI 1931, 112
55 Bierbauer 1928

${ }^{56}$ Móricz 1936, 10.

57 ORDASI 2007.

58 BierbaUer 1935, 144

59 BierbaUer 1935, 144-145.

${ }^{60}$ FOGU 2005, 40-49.

${ }^{61}$ Tér és Forma 9. 1936. 203.

62 G. M. 1935; Golan 2009, 134.

${ }^{63}$ For more about the fifth triennial in 1933, see: Architettura. V. Triennale di Milano. Fascicolo speciale con 497 illustrazioni, Milano-Roma, Fratelli Treves, 1933; the exhibition of photographic illustrations in 1933 was entrusted to experts from each given country, but in 1936 the pictures relating to Hungary were selected and mounted under Pica's direction in the international architecture section: Az 1936 évi VI. milanói Triennale építészeti kiállítása, Tér és Forma 9. 1936. 287-292.

${ }^{64}$ The signatures "Designed by Dr Virgil Bierbauer," "Montage by György Radó," and "Executed by F. Szántó" can be read next to the montage: Tér és Forma 6. 1933. 99.

${ }^{65}$ A hatodik év elején, Tér és Forma 6. 1933. 100.

${ }^{66} \mathrm{Az}$ 1936. évi VI. milanói Triennale építészeti kiállítása, Tér és Forma 9. 1936. 287-292.

${ }^{67}$ FeRKAI 2010, 94.

68 SiPOS 2013.

${ }^{69}$ From 1926 it was edited initially by János Komor, and the foreword to the first issue was written by the art historian Károly Lyka.

${ }^{70}$ The periodical was renewed in 1928 , as announced in Tér és Forma 1. 1928. 7.

${ }^{71}$ MOLNÁR 1928, 198

72 Zoltán Seidner was a pay-roll staffer of Tér és Forma in between the two world wars.

${ }^{73}$ MeZei 1981, 79-80.

${ }^{74}$ Mezei 1981, 3.

75 Bierbauer 1930

${ }^{76}$ BAudin 2005, 16.

77 BAUdin 2005, 110

78 BAUdin 2005, 106.

${ }^{79}$ Budapest, Budaörsi Közforgalmi Repülőtér Pályaterve. Alaprajz. 1937. [Budapest, Budaörs Civil Airport Competition Design. Floor plan. 1937.] (The description can be read on the floor plan, which is on laminated card): MÉM, inv. no. 60.013.3.2.

80 BORBíRÓnÉ, Palackposta IV. (1934-1942), 292-294

${ }^{81}$ For the competition designs see: Exh. Cat. Budapest 1981, No. 6-7: front elevation and floor plan; BIERBAUER 1938, 263; For the construction plans and cross-sections, see: Budapest 1937, 212, 214, 216.

82 BFL XV. 17. d. 328. K. 34/4. fiók.

83 Bierbauer 1938, 263. (12. ábra).

${ }^{84}$ The description on the competition design sheets in the Hungarian Museum of Architecture allow us to deduce that Bierbauer also intended the terraces to function as an outside auditorium or tribune. The architect did not give a final solution for this here, however, leaving open the possibility of a future pedestrian subway leading from the planned car park and railway (suburban railway).

85 Bierbauer 1938, 263. (12. ábra).

${ }^{86}$ The building was constructed in accordance with the planning permission drawings, and it is likely that no separate construction drawings were ever made, although in his 
publications, Bierbauer refers to the implemented condition as the "construction design." For the construction drawings, see: Budapest 1937, 214, 216.

${ }^{87}$ HL. VII. 244. Katonai objektumok építési anyaga. 1942-1944. 1914 elốtti Budaörs, Budapest. 20. doboz.

${ }^{88}$ BFL XV. 17. d. 328. K. 34/4. fiók.

89 TÖRÖK 1937, 289.

90 BiERBAUER 1936.

${ }^{91}$ MNL-OL, K. 27.1935.107.b

92 Borbíró 1948: IV. levél, Budapest, 1948. IV. 6., 4.

93 Budapest 1937, 220-221.

${ }^{94}$ In recent years, international research has increasingly focused on the history of propaganda photography and of printed media illustrated with pictures: RiBALTA 2008.

${ }^{95}$ FERKAI 1999, 13.

${ }^{96}$ About Stockholm Bromma airport (Paul Hedqvist, 1936) he wrote: "...to anyone who can understand the floor plans and constructions of new airports in northern Europe, it will be apparent how much simpler and easier life is in the Baltic nations! These buildings are dominated by a longitudinal-shaped passenger hall, the reason being that life there does not involve the same kind of administrative burden as here at home." - BIERBAUER 1938, 280.

${ }^{97}$ Bierbauer 1938, 283.

98 Borbíró 1948: IV. levél, Budapest, 1948. IV. 6., 4-5.

99 Szigethy, Endre: Beszálló teleszkópok, bádoghernyók, liftek és alagutak a repülôterek berendezésében. A budaörsi állomás Európa egyik legmodernebb repülő állomása lesz, Nemzeti Újság 1936 (április 26.), 7; Pompásan sikerült a vasárnapi repülônap fốpróbája, Uj Magyarság 1937 (VI. 20.); Kitûnôen sikerült a három nemzet vadászrepülőinek fốpróbája Budaörsön, Magyarság 1937 (június 20.), 18; A budaörsi repülôtér megnyitó ünnepe, Magyarság 1937 (június 22.): illustrated report (with footage by the Hungarian Film Office and Orelly); Horthy Miklós kormányzó felavatta a budaörsi repülőteret, Függetlenség 1937 (június 22. kedd): illustrated title page.

100 Felavatták Budapest új repülőterét. Négy nemzet pilótáinak páratlan bravúrjai a gyönyörû budaörsi mezô felett 100.000 ember tapsviharában, Pesti Napló 1937 (június 22.), 10; A budaörsi repülőtér megnyitó ünnepe, Magyarság 1937 (június 22.): illustrated report (with footage by the Hungarian Film Office and Orelly); SimOR, Miklós: Százezernyi közönséggel, észvesztố mutatványokkal nyílt meg vasárnap Budaörsön Európa legmodernebb légi kikötóje (Fotó: Fischer Andor), A Reggel 1937 (június 21.), 3; BÁró GudENUS, Leó: Káprázatos légi pompával megnyitották Budapest új repülôterét. Magyar, olasz, német és osztrák csodapilóták hajmeresztố bravúrjai a kormányzó és százezer nézô elôtt, Hétfối Napló 1937 (június 21.), 3.

${ }^{101}$ MÉM Borbíró-hagyaték, 7. doboz. "Levelezés R". 31. levél.

102 Bierbauer 1938, 260.

103 Bierbauer mentioned (BIERBAuER 1938, 260) that he had a copy of the study by John DOWER and G. R. DAWBARN: Journal of the R. I. B. A. 1931. No. 11., 1932. No. 13. 15.

${ }^{104}$ MÉM Borbíró-hagyaték, 6. doboz. Kapcsos dosszié. "Levelezés H". 10. levél (Letter from H. S. Goodhart-Rendel to Virgil Bierbauer, London, 9 December 1935).

${ }^{105}$ MÉM Borbíró-hagyaték. 6. doboz. Kapcsos dosszié. "Levelezés H". 11. levél. (Letter from H. S. Goodhart-Rendel to Virgil Bierbauer, London, 14 December 1935). For the description of the building at Lichfield Court, Richmond see: ibid., 11/a. levél; The outstanding photographs he was sent were published in Hungary alongside a lengthy article titled "The future of architecture": [rl] 1936.

${ }^{106}$ Letter from Wells Coates to Virgil Bierbauer, London, 5 February 1936: MÉM Borbíró-hagyaték, 6. doboz. Kapcsos dosszié. "Levelezés A-G, H-M." 34. levél.

107 Letter from Wells Coates to Virgil Bierbauer, London, 16 February 1937: MÉM Borbíró-hagyaték, 6. doboz. Kapcsos dosszié. "Levelezés A-G, H-M." 35. levél.

108 Bierbauer 1936, 145; This was followed by the study titled "The future of architecture", accompanied with photographic illustrations of the Embassy Court building, inspired by the H. G. Wells film What is Coming?: Az építészet jövóje, Tér és Forma 9. 1936. 119-126. For a description of the building in English see: MÉM Borbíró-hagyaték, 6 . doboz. Kapcsos dosszié. "H" Levelek a Royal Institute of British Architects-tôl. 11. és 11/a. levél.

${ }^{109}$ Letter from M. H. Volk, aeronautical consultant, to Virgil Bierbauer, Brighton, 30 June 1936: MÉM Borbíróhagyaték, 7. doboz. "M-W." téka/T". 61. levél. - According to the hand-written comment on the letter, Pál Elischer, of the Aviation Office, put Bierbauer and Volk in touch, even before the airport was officially opened.

110 "Je complète en effet actuellement une documentation générale sur les aéroports en vue d'assurer des travaux d'achèvement de l'aéroport du BOURGET et je serais heureux de profiter de votre expérience personnelle à ce sujet. Je vous serais reconnaissant notamment de vouloir bien me faire connaître si vous estimez qu'un hötel et un restaurant aient leur place dans l'aérogare même et à quel étage et à quel endroit de votre plan, vous avez prévu ces deux éléments." - Letter from Georges Labro to Virgil Bierbauer and László Králik, Paris, 4 January 1938: MÉM Borbíró-hagyaték, 7. doboz. "T" téka ("Al Tremlett" dosszié). 54. levél.

${ }^{111}$ Bierbauer began the second part of his study, titled "Airport architecture," by describing the building at Le Bourget: BiERBAUER 1938, 277-278.

112 Draft letter from Virgil Bierbauer to Labro: MÉM Borbíró-hagyaték, 7. doboz. "T" téka ("Al Tremlett" dosszié). 54. levél (handwritten on the reverse of the letter).

113 Ibid.

${ }^{114}$ Letter from Georges Labro to Virgil Bierbauer, Paris, 17 January 1938: Borbíró-hagyaték, 7. doboz. "T" téka ("Al Tremlett" dosszié). 56. levél.

115 Letter from M. H. Volk, aeronautical consultant, to Virgil Bierbauer, Brighton, 19 July 1936: MÉM Borbíró-hagyaték, 7. doboz. "T" téka ("Al Tremlett" dosszié). 63. levél.

${ }^{116}$ In 1935 Beatrice Plummer, wife of the publisher of the London Daily Express, thanked the Bierbauers for their kindness during her stay in Budapest. The handwritten note attached to the letter Mrs Plummer wrote to Mrs Bierbauer informs us that László Moholy-Nagy introduced her to the Bierbauers, who wanted to make her acquaintance in Budapest for the purpose of making mutual connections. (I have not yet located Moholy-Nagy's letter of 25 July 1935 in the Borbíró estate.): letter from Beatrice Plummer, London, 21 September 1935: MÉM Borbíró-hagyaték, 7. doboz. "P" téka. 42. levél.

${ }^{117}$ MÉM Borbíró-hagyaték, 7. doboz. "N-W" téka/"N".

118 The architect G. L. Torok helped to coordinate Bierbauer's appearance in English architectural periodicals in 
1937. Bierbauer originally wanted to have an article on Budaörs Airport published in Architectural Review or in Architect, but G. L. Torok, in his letter, regarded Architectural Design and Construction as a more realistic option: letter from G. L. Torok to Virgil Bierbauer, London, 2 September 1937: MÉM Borbíró-hagyaték, 7. doboz. "Levelezés T". 42. levél; the article was published in the November 1937 issue of Architectural Design and Construction: BIERBAUER 1938, 283.

119 Besides the letters in his estate, the official bulletin of the Hungarian Union of Engineers and Architects ( $A$ Magyar Mérnök- és Építész-Egylet Közlönye) also published the sources of reports on the airport: BIERBAUER 1938, 283.

${ }^{120}$ Letter from the RIBA library, thanking Bierbauer for the newspaper clipping from Nemzeti Újság containing the article about the airport, London, 4 May 1936: MÉM Borbíróhagyaték, 7. doboz. "R" mappa, 32. levél, and "Levelezés R". 33-35. levél.

${ }^{121}$ Letter from G. E. Marfell, secretary of RIBA, thanking Bierbauer for the three photographic prints, London, $8 \mathrm{Sep}-$ tember 1938: MÉM Borbíró-hagyaték, 7. doboz. "Levelezés T”. 60. levél.

122 Bierbauer 1938.

${ }^{123}$ Photograph of Prague Airport (architect: Adolf Benš): ZuKOWSKSI 1996, 114.

${ }^{124}$ In their report of 4 February 1936, the committee for the construction of Birmingham Airport declared that the dynamic development of increasing European air traffic would soon make it necessary to rebuild existing airports or to construct completely new ones.

125 BierbaUer 1938, 261.: "It seems that the railway termini of the nineteenth century also experimented with the spatial arrangement of having long passenger halls perpendicular to the actual direction of traffic: upon entry we step into a large hall, one side of which (towards the tracks) is filled with ticket offices, from where passengers are dispersed, both left and right, in a perpendicular direction, taking the shortest natural straight line. In stations this can be achieved, because the departing train itself is also stretched out longitudinally, so it is sensible for the crowd of passengers to be able to step onto the platform via a multitude of doors. On an aeroplane, however, passengers embark via a single door."

126 The series of conferences was founded at the behest of the factory magnate Volta: when he was exiled, he donated his wealth to the Italian Royal Academy on condition that the foundation hold annual conferences dealing with a different subject each year, to which scientists and artists would be invited to debate the issue at hand. Previous years had focussed on the theatre (1934) and on rapid flight (1935), which Bierbauer described as the topic of "aerial velocities."

127 The German was far smaller than the Italian and French contingents, although it included Paul Bonatz, a member of Nazi Germany's leading group of architects. Alongside members of the architectural and artistic elites, an invitation was also extended to the architect Erich Mendelsohn, who had fled Germany after Hitler's rise to power, and who also achieved major successes in the field of modern photography.

128 UdDOVICKI-SELB 1997, 52.

129 There is hardly any literature dealing with the conference; the most important of the few writings that exist is the monograph by Rony Golan (GOLAN 2009), which primarily covers the role of Le Corbusier.

130 The interview with Gerevich is from an unidentifiable newspaper, known from a newspaper cutting with the title "A világ leghíresebb építészei, mûvészei és szakértôi megállapították a modern építészet új irányát. A római Voltakongresszus érdekes vitái és eredményei" (probably 1936 or 1937): MÉM Borbíró-hagyaték, 11. doboz.

131 [K.M] 1937.

132 The manuscript was originally a 15-page lecture written for the members of the Hungarian Union of Engineers and Architects: BIERBAUER 1937A. The lecture contains a number of details that were omitted from the printed article (cf. note 130). It is possible that the reason the text was not published in full lies in the conflict that arose from the fact that certain commentators regarded Bierbauer's positive preoccupation with monumental Italian architecture as enthusiasm for the political message behind modern architecture.

133 [K.M] 1937, 4.

134 Borbíróné, Palackposta IV. (1934-1942), 284-285

135 Ibid., 285.

${ }^{136}$ Ibid., 285.

137 [B.] 1937.

138 BorbírónÉ, Palackposta (in the course of my research I used the copies of Palackposta in the collection of the Hungarian Museum of Architecture)

${ }^{139}$ After the architect's death, his widow sorted and arranged his entire estate.

140 Borbíróné, Palackposta I. (1915-1920), 34

141 'A Szépmûvészeti Akadémia növendékeinek anyakönyvi és minôsítvényi lapja az 1916/1917. tanév második felérôl' ["The registration and certification sheets of the pupils at the Academy of Fine Arts for the second semester in the academic year 1916/1917"]: MKEL, 11/a. 79. kötet, 30.

142 According to the list of officers' names and addresses in Hungary (1873-1944), their address in Budapest was 83 Baross Street (8th District) in 1915 and 67 Vörösmarty Street (6th District) in 1912

143 Ada Ackermann was a second-year student in 1917 , and a third-year student in 1918. The second semester of the academic year 1916/1917 ended on 28 January 1917 , the first semester of $1917 / 1918$ ended on 22 December 1917 , and the second semester of 1918/1919 ended on 20 March 1919: MKEL, 11/a. 77-95. kötet.

${ }^{144}$ The list of students who attended the National Hungarian Royal College of Fine Arts between 1871 and 1929 also features the names Kálmán Marsovszky (1886/87-1891/92), Emilia Marsovszky (1928/29) and Mrs Endre Marsovszky, widowed (1900/1901): http://www.mke.hu/sites/default/ files/attachment/evkonyv_1928-29_0.pdf

145 According to the information provided by the Holocaust Memorial Center in Budapest, Ada Ackermann, Mrs Elemér Marsovszky, is not on their register. What became of the photographer after 1945 will require further research.

146 BIвÓ 2011, 939; The connection between the Bibó and Bierbauer families dates back to 1917/1918, when it was becoming clear to increasing numbers of people that Hungary was on the losing side of the World War. Adrienn's elder brother was sent to the Italian Front, and his parents worried constantly about his future. The young girl did what she could to escape from the oppressive atmosphere and everyday problems at home. She played the piano, read literature 
(Plato, Freud, Nietzsche, Thomas Mann), and corresponded intensively with Virgil Bierbauer, who was completing his studies in Munich, and who had returned from the Russian Front in 1916. Borbíróné, Palackposta I. (1915-1920) $1-113$.

147 Borbíróné, Palackposta III. (1926-1934), 187-189.

148 Borbíróné, Palackposta III. (1926-1934), 188, note on the back of page 187 .

149 BorbírónÉ, Palackposta I. (1915-1920), 1.

150 Borbíróné, Palackposta I. (1915-1920), 3.

${ }^{151}$ Borbíróné, Palackposta, VIII. ('Epilógus'), 484-485.

152 BIBÓ 2011.

153 LENKEI 2009, 93-94.

154 BeKe 2013, 13. - Dénes Rónai (1875-1964); Kata Kálmán (1909-1978); Angelo (Pál Funk, 1894-1971); André Kertész (1894-1985); Ergy Landu (Erzsi Landau, 1896-1967); Lajos Lengyel (1904-1978).

155 BORECZKY 2013, 54, 56

156 Budapest, VII. Vilma királyné út (today the street is called: Városligeti fasor) 3.

157 FERKAI 2011, 362.

158 OVERY 2007, 9-13.

159 KARÁDY 1994, 176-195.

160 Original photographs of the journey taken by the Italian pilots to Budapest (14 June 1936) are still found in the collection of Alberto Montanari (Arch. Montanari): http:// www.asso4stormo.it/arc_03/arc_03_02/arc_03_02_01/ link_03_02_01_005.htm.

${ }^{161}$ Borbíróné, Palackposta IV. (1934-1942), 293-294.

162 As reported by Károly Kincses.

163 [K.M.] 1938, 5.

${ }^{164}$ Csorba 2000, 255; two works on the history of photography written by György Kreilsheim, who interwove his narratives with many tales, are still regarded as important sources: one, originally published in 1941, is titled 'Régi magyar fényképezés' [Old Hungarian photography] (KREILSHEIM 1941), while the other, the manuscript which was not published until 1998, is titled 'A fotográfia regénye' [The novel of photography] (KreILSHEIM 1998). An as-yet unpublished radio lecture by Kreilsheim from 1940 can be found on the internet portal of Budapest City Archives: http://bfl.archivportal.hu/id-232-kreilisheim_gy_rgy_100_ eves.html

165 BACSKAI 1993, 46.

166 The book features genre pieces by Mrs Elemér Marsovszky showing rural houses, titled 'Csendes otthon' [Peaceful home]: Rosner (ed.) 1939, fig. 16.

${ }^{167}$ A bútor III. 1936. No 4. 38-39.

168 Tér és Forma 14. 1941. No 3. 45.

${ }^{169}$ The exhibition of the National Society for Public Health at the Budapest International Fair in 1932 was compiled by the studio of Városy-Marsovszky: Színházi Élet 1932. No 25. 87.

${ }^{170}$ Nevertheless, positive changes can be felt in the field of research into the history of photography. In recent years there have been several new publications and exhibitions presenting the results of research into women photographers, including Irén Blüh (Irena Blühova, 1904-1991) in 2009, Kata Kálmán in 2011 and Judit Kárász (1912-1977). Éva Bajkay, who has spent decades researching Hungarian Bauhaus students, published an article about Etel Fodor, a photographer from Pécs, in 2005: BAJKAY 2005.
${ }^{171}$ Marta Aczél joined the Iparterv (industrial design) company in 1950, and afterwards she worked as an industrial photographer. She travelled the entire country in the course of her work. (As reported by Károly Kincses.)

172 CSORBA 2000.

173 OtTo 2005.

${ }^{174}$ Exh. Cat. London 2007, 184.

175 BiRO 2013, 374.

176 This study is still a standard work in the history of media and photography: Benjamin 1936.

177 FREUND 1976.

${ }^{178}$ I was guided to the writings of Freund by the book written by Rony Golan: Golan 2009.

${ }^{179}$ Budapest 1937: Out of a total of 74 photographs, 28 were of the terminal building, 11 of the hangar, 6 of the service buildings, 3 of the wind measuring devices, 13 of the news and weather communication equipment, and 6 of the new business premises of MALERT, the Hungarian airline, in central Budapest. In addition, there are two further aerial photographs in the volume that do not credit the original source. The 28 adverts at the end of the special issue enable us to build up an accurate picture of the specialists and companies who worked on the construction of the airport. Based on the information pertaining to the photographers, the series of photographs showing the terminal building (pp. 213-227) was the work of "Marsovszky Elemérné Belvárosi Fotómúhely" [The City Centre Photo Studio of Mrs Elemér Marsovszky]. The photos of the hangars (pp. 228-232) were taken by Zoltán Seidner: "Foto: Seidner." Mrs Marsovszky is also credited with the photographs of the weather forecasting service (p. 240), albeit with her name misspelt: "Idôtérkép rajzolása Fotó: Marschovszky" (Time map drawing, Photo: Marschovszky).

180 Budapest 1937, 207-209.

181 BIERBAUER 1937B.

182 Photographic album of Budaörs Airport, with original prints by Mrs Elemér Marsovszky: MÉM Borbíró-hagyaték. 21. doboz.

${ }^{183}$ Exh. Cat. Budapest 1999; Csengel-Plank - Hajdú RiTOÓK 2003.

${ }^{184}$ Advert for rubber flooring, in Budapest 1937.

185 BTM Kiscelli Múzeum, Fényképtár, inv. no. 38863920/9×12 (32 black-and-white print films, bought from Béla Hollenzer in 1955).

186 Hausmann 1931; excerpt reprinted in Phillips 1989, 178-181; the catalogue for the photomontage exhibition in Berlin was designed by the avant-garde artist César Domela Nieuwenhuis, who accorded photomontage a key role in modern graphic design; an abridged version of his writing: DOMELA NiEUWENHUIS 1989; some of the most important literature about montage: RoH 1929; CROY 1939; BONI 1962; NEWHAll 1980; Ades 1986; Evans-Gohl 1986; Perloff 1986; Phillips 1989; Teitelbaum 1992; Warner Marien 2010.

${ }^{187}$ Montage and collage are two separate genres: collage involves making a new work of art by combining paper, photography, textile, wood, metal and/or other materials (mixed media); montage, originating from the early twentieth century, is a method whereby pre-existing pictures and drawings are arranged in a new way.

188 KASSÁK 1999; WANAVERBECQ-Morocz 2004, 30.

189 KASSÁK 1999.

190 BEKE 2009, 285-287. 
191 Albertini 1993, 52-60.

192 Moholy-Nagy 1925.

193 Moholy-Nagy 1929.

${ }_{194}$ Moholy-Nagy 1947.

${ }^{195}$ For more about the significance of the writings by Moholy-Nagy that appeared in the periodical Korunk, published in Kolozsvár (Cluj, now Cluj-Napoca, Romania), see: MEZEI 1979.

196 BROGYÁNYI 1932; BROGYÁNYI 1933.

197 BrogyánYI 1932, 209.

198 Péter Baki, in his dissertation titled "A fotográfia és a magyar sajtó kapcsolata 1945-ig" [The relationship between photography and the Hungarian press until 1945], discusses the late triumph of modern art photography: BAKI 2011.

199 KosZTOLÁnyI 1931.

${ }^{200}$ Exh. Cat. Stuttgart 1929. Among the members of the preparatory committee for the exhibition were the art historian Hans Hildebrandt, the architect Bernhard Pankok and the typographer Jan Tschichold. Among the organisers were also the Bauhaus teacher László Moholy-Nagy, the American photographer Edward Weston, Edward Steichen from New York, El Lissitzky from the Soviet Union, and the art historian Sigfried Giedion.

${ }^{201}$ Exh. Cat. Budapest 1930; for more about the objectives and outcomes of the exhibition of advertising and publishing art, see: PÉCSI 1930A; the Hungarian Association of Book and Advertising Artists was founded on 5 May 1926 in the state hall of the Museum of Applied Arts, Budapest, in the presence of artists including Róbert Berény (1887-1953), Sándor Bortnyik, Álmos Jaschik (1885-1950), Gyula Kaesz (1897-1967), Lajos Kassák, Albert Kner (1899-1976), Erzsébet Kner (1897-1998), Lajos Kozma, László MoholyNagy, Pál Molnár-C. (1889-1981) and József Pécsi: Magyar Grafika IX. 1928. 178-179.

202 Magyar Iparmúvészet 33. 1930. 132; Etel Fodor, who had an adventurous life, also participated in the exhibition; for her design for a photomontage poster, see: Magyar Grafika XI. 1930. No 9-10, 283.

203 KasSÁ́ 1999, 20; KASSÁK 1930.

${ }^{204}$ Magyar Fotográfia X. 1930. No. 6. 6.

205 BORTNYIK 1930, 277-278.

${ }^{206}$ Fotografický obzor 1931. 5-8; Albertini 2003, 86, 164; ADES 1986, 17.

207 Bierbauer 1937C.

208 SCHUlz 1934-1935.

${ }^{209}$ Magyar Grafika XII. 1931. 26.

210 Magyar Grafika XI. 1930. 267.

211 Magyar Grafika X. 1929. 261.

212 László Moholy-Nagy had a separate name for montage-like pictures in which the composition was defined by photographic details placed along lines. By simultaneously showing visual and drawn elements it is possible to achieve much more than with "the Dadaists' first [compositions], made by sticking together photograph cuttings." The term "photoplastics" [Fotoplastik, also known in English as "photosculpture"] was short-lived, however, although the words "typophoto" and "phototypography," as a means of distinguishing montages that featured lettering and inscriptions, lasted somewhat longer. In the mid-1920s, political and advertising posters in Russia began to combine drawn and photographic elements. For the masters of political posters based on photomontage, see: Exh. Cat. Budapest 1988.
${ }^{213}$ Moholy-NaGy 1978, 36. English translation by Janet Seligman. (https://monoskop.org/images/c/cb/MoholyNagy_Laszlo_Painting_Photography_Film.pdf)

${ }^{214}$ Magyar Grafika XI. 1930. No 9-10. 291-293.

215 RoH-TsCHICHOLd 1929.

216 Tér és Forma 3. 1930. 142.

217 Molnár 1931, 69-70.

218 PÉCSI 1930C, 257.

219 PÉCSI 1930B; only published in Hungarian in 1997: PÉCSI 1997.

220 RÉVÉSZ-BIRÓ 1931.

221 GENTHON 1925.

222 Some commentators regard the objectivity of a photograph as dependent not only on the technology but also on the degree to which it complies with the social and professional demands and beliefs placed in the photograph: WELLS 1997, 283.

${ }^{223}$ For the Exposition Universelle in Paris in 1937, Vilmos Aba-Novák painted a panneau measuring 28 metres in length and 8 metres in height, titled The Historical Connections between Hungary and France (Magyar-francia történelmi kapcsolatok): SUPKA 2008.

${ }^{224}$ The School of Rome (római iskola) is the Hungarian version of Italian neoclassicism and novecento art. Beginning in 1928 its exponents enjoyed the support of official art policy as recipients of scholarships to the Hungarian Academy in Rome. The neoclassical style, combining modernity with Catholicism and the new national style, was used in new ecclesiastical painting as well as in art dealing with propaganda and current affairs. See: ZWICKL 1999.

225 ABA-NovÁk 1931, 136; NAgy 1941, 99; Molnos 2009, 33.

226 Due to the rarity and irregularity of the terms, and the multiple ways in which they are used in contemporary parlance, in the case of the photofresco and the photomural I shall endeavour to stick to the original way the terms were used. Only non-Hungarian sources are available for understanding the genre: "Photomural: a photographic blow-up enlarged to the dimensions of a wall space and attached to it with wallpaper paste or other adhesive, an art form of the mid-20th century": Harper Collins Dictionary 1991, 310.

${ }^{227}$ NAEGELE 1998, 134.

228 GOLAN 2009, 130.

229 Golan 2009, 123, 128.

230 Golan 2009, 128-129.

231 TUPITSYN 1999. 59-63.

232 Murals 1932; Exh. Cat. New York 1969, 5-6.

233 Exh. Cat. New York 1969, 11.

${ }^{234}$ Exh. Cat. Cambridge-Boston 1992, 148-151.

235 The restoration of the former royal palace in Esztergom (1934-1937) received substantial financial support from the state. The restoration was carried out in line with the latest principles, so that all the architectural elements whose original location could be scientifically proven were put back in place; anything that needed replacing was done using contemporaneous materials, where possible, and every stage of the work (excavation, fragments of stone and murals, construction) was documented in detail using photography. Photographs of historic monuments, topography and artworks were all of a very high quality in this period, as can be seen from the photographic documentation made during archaeological digs in both Esztergom and Székesfehérvár. Bozóki 1996, 178, 186; DeRCSÉNYI 1980; SzỨCS 1988. 
${ }^{236}$ Letter from Ferenc Zsindely, secretary to the minister of religion and education, to G. Emil Csitáry, mayor of the city of Székesfehérvár: Székesfehérvár Megyei Jogú Város Levéltára, IV. B. 1406. (Archive documents of the murals by Vilmos Aba-Novák in Székesfehérvár). Budapest, 1938. augusztus 25. Ikt. sz. 13.986/1938. szám III.

${ }^{237}$ MolnáR C. 1941, 143-188.

238 Exhibition at the National Salon in 1937 titled "Hungarian Monumental Art” (Magyar monumentális múvészet). The exhibition featured Vilmos Aba-Novák's panneau designs for the Exposition Universelle in Paris and for the Central Post Office in Budapest, as well as a Pietà by Jenó Medveczky. Photo: MTA BTK MI Fotótár: Gerevich Tibor fotóhagyatéka, B3963. - communicated in: MARKóJA BARDOLY (eds) 2009, 63.

239 Golan 2009, 128.

240 Photo-mural 1937; the illustrated guide also showed two pictures of the inside of Embassy Court (Brighton): architect: Wells Coates; fresco designed by: E. McKnight Kauffer; carried out by, and using a process invented by: Eugene Mollo and Michael Egan.

${ }^{241}$ The photofrescos that appeared in print were all carried out by a company belonging to the inventors: "All this work has been carried out by Messrs. Photographic Spraying, Ltd., a subsidiary company of Mollo and Egan, architectural decorators and inventors of the process. All photography also by Photographic Spraying, Ltd.": Photo-mural 1937, 88.

242 Bierbauer 1937C, 733.

243 EYLES 1998.

${ }^{244}$ New technique 1932

245 EGAN 1998, 5-13.

246 EYLES 1998, 4.

247 This example was also presented in the February 1937 issue of Architectural Review, which dealt with photomurals: Photo-mural 1937, 87; ill. 9.

248 EGAN 1998, 10.

${ }^{249}$ EYLES 1998, 10; one of the unexpected revelations of the research was finding, with the help of James Dawn (University of Exeter), the patent specification for the photofresco drawn up by Mollo and Egan: A New Method of Decorating Large Surfaces by Photography. (PATENT SPECIFICATION. 429, 173. Application date: Oct. 2, 1934. No. 29524/33. Complete Specification Accepted: May 27, 1935): http://www.google.com/patents/US2041853

250 Bierbauer 1937C, 736.

251 Bierbauer 1937C, 733, 736.

252 Bierbauer 1937C, 738.

${ }^{253}$ Márciusban megnyílik Budaörsön Európa legmodernebb repülôtere [Europe's most modern airport opens in Budaörs in March], Magyarság 1936, december 25., 8: the artist's visualisation is signed "Dr Virgil Bierbauer."

${ }^{254}$ Budapest 1937, 221.

255 Bierbauer 1936; Bierbauer 1937C; Bierbauer 1937B.

256 Bierbauer 1937C, 736.

257 Bierbauer 1938, 267.

258 SOULAGES 2011, 267-277.

259 Bierbauer 1937C, 734.

260 Bierbauer 1937B, 226.

261 Bierbauer 1937B, 226.

262 GOLAN 2009, 128-129.

263 Bierbauer 1937C, 734.

264 Bierbauer 1937C, 735.
265 Bierbauer 1937C, 735.

266 Bierbauer 1937C, 734.

267 Bierbauer 1937C, 735.

268 "Hour by hour, as I observed and, to an extent, directed the construction of the photomontage boards, I witnessed at first hand the requisite creative work and dedication, for which we strove from the very beginning." BierbaUER 1937B, 226.

269 Bierbauer 1937C, 733.

${ }^{270}$ For more about the exhibition held to mark the tenth anniversary of Mussolini's accession to power, see: GOLAN 2009, 133-134.

271 BieRBAUER 1937B.

272 Hausmann 1931, in Phillips 1989, 178.

273 Bierbauer 1937C, 735.

274 Bierbauer 1937B, 224.

275 Bierbauer 1937C, 736.

276 Bierbauer 1937C, 736.

277 Bierbauer 1937C, 736.

278 BieRBAUER 1937C, 736.

279 Bierbauer 1938, 268.

280 Bierbauer 1937B, 225.

281 Bierbauer 1937B, 225.

282 Moholy-Nagy 1928, in Passuth 1982, 307-308; English translation by Frederic Samson (https://monoskop.org/ images/8/81/Bauhaus_Photography_1985.pdf)

283 Moholy-Nagy 1928, in PASSUTH 1982, 307.

${ }^{284}$ Moholy-Nagy 1925; Moholy-Nagy 1978 , 118-133.

285 "Photosculpture [Fotoplastik] is based on visual and mental gymnastics presented in more concentrated form than that which befalls a city-dweller on his daily rounds": Moholy-Nagy 1928, English translation by Frederic Samson (https://monoskop.org/images/8/81/Bauhaus_Photography_1985.pdf); MoHOLY-NAGY 1978, 308.

286 [K.H.] 1937, 221-222.

287 "Kötelező és nyugta. Kelt: Budapest, 1937. április 24." HL, jelzet nélkül.

288 BiERBAUER 1937D

289 Kozma 1938, 180-181.

290 Bierbauer 1937B, 225.

${ }^{291}$ MÉM, Borbíró-hagyaték 21. doboz (Fényképek).

292 BTM Kiscelli Múzeum, Fényképtár, inv. no. 38863920/9×12.

293 In Budapest 1937.

294 BiERBAUER 1937C, 732-733.

295 The name was written in the article by mistake as Hódmezôvásárhely instead of Hajdúböszörmény.

296 Kozma 1938, 180-181.

${ }^{297}$ Budapest 1937, 207-209.

298 BierbaUer 1938, 267.

299 BiERBAUER 1937B, 224.

300 KozMa 1938, 180.

${ }^{301}$ BierbaUer 1937C, 735.

302 BTM Kiscelli Múzeum, Fényképtár, inv. no. 3886$3920 / 9 \times 12$

303 MoraVÁnsZKY 2000.

304 LODDER 2004.

305 Budapest 1937.

306 BiERBAUER 1937D

307 SinKÓ 2012/1988, 222-227.

308 Kolta 2003, 66-72.

309 KovÁCS 1997, 23. 
310 PeternÁK 2002.

311 KováCS 1996; Kovács 1997.

312 KovÁCS 1997, 25.

313 The moving panorama was presented in Pest in 1852 under the name of "cyclorama": Kolta 2003, 65.

314 Moholy-Nagy 1929; MoHoly-Nagy 1972, 223. (https:// books.google.hu/books?id=Wn3CAgAAQBAJ\&pg=RA1PA179\&lpg=RA1-PA179\&dq $=\% 22$ useful+guide +to+the+airplane+pilot $\% 22 \&$ source $=$ bl\&ots $=u_{-}$ WhGijW20\&sig=j4iRl-bwBcMSX-TsEpFK7gLlP9Y\&hl=e n\&sa $=X \& v e d=0$ ahUKEwiCw-H0q4HWAhUFmrQKHYIFAc0Q6AEIJjAA\#v=onepage $\& q=\% 22$ useful $\% 20$ guide $\% 20$ to $\% 20$ the $\% 20$ airplane $\% 20$ pilot $\% 22 \& f=f a l s e)$.

315 WOOD 2004, 78.

316 BieRBAUER 1938, 283.

317 Le Corbusier 1981, 12-13.

318 Le Corbusier 1935, Figs. 97-98.

319 LODDER 2004, 25-40.

320 LODDER 2004, 37.

${ }^{321}$ The Aeroplane was published in 1911 in Camera Work No. 36.

322 SZEGEDY-MASZÁK 2004, 41-42.

323 SiUKONEN 2001.

324 History of Photography 28. 2004. Spring, 1-56; History of Photography 28. 2004. Autumn, 1-43, specifically: LoDDER 2004; SZEGEDY-MASZÁK 2004.

325 SZKÁROSI 2010; Budapest 2010

326 HAFFNER 2013

327 Among them was the observer Sándor Neogrády, who would later work as a cartographic aerial photographer: BALLA-HRENKó 1991, 39, 41.

328 For the different name variants, see: BALLA-HrENKó 1991, 93

329 BALLA-HRENKó 1991, 52-53.

330 BALLA-HRENKÓ 1991, 139.

${ }^{331}$ For the operations of the Department of Photogrammetry, see: BALLA-HRENKó 1991, 137-162; at the time when Budaörs Airport was built, the work of aerial photographers was processed by the photogrammetry subgroup of the Geodesic Group of the Hungarian Royal Institute of Cartography; the aerial photographs were used as the basis for the production of photographic maps of flat and gently hilly terrain by the Department of Planar Photogrammetry, and of stereophotogrammetric maps of hills and mountains by the Department of Spatial Photogrammetry.

332 MarinetTI 1909. Further references to the text are based on the anthology edited by Luciano De Maria: Marinetti 1973, 3-9.

333 The "Manifesto dell'Aeropittura" was issued on 22 September 1929 by Giacomo Balla, Benedetta Cappa, Fortunato Depero, Gerardo Dottori, Fillia, Filippo Tommaso Marinetti, Enrico Prampolini, Mino Somenzi and Tato [Guglielmo Sansoni], who presented their works at exhibitions in Italy in 1931, Paris in 1932 and Berlin in 1934.

334 LisTa 2001, 78-79.

335 BEKE 2000, 213-217.

336 NAHÓCZKY 2010, 464

${ }_{337}$ Mughini 2000, 13-30; DÁvid 2010, 352-358.

338 DÁVID 2010, 356.

339 Stiller 2000, 84-100; Ferkai 2012.

340 STÜHLINGER 2012, 20, 31.

341 STÜHLINGER 2012, 22
342 VÁRKONYI 1947, 3.

${ }^{343}$ In an interview (Pesti Napló 1936. február 14., 8; reprinted in: MARKÓJA - BARDOLY (eds) 2009, 65), Tibor Gerevich spoke about his proposal to decorate public buildings with works of art, which would make up a maximum of $2 \%$ of the gross cost. The motivation behind the idea, copying the Italian model, was to help artists financially, as well as to support Hungarian monumental art. Even at the session of Budapest Municipal Council held on 21 March 1929, a statement was issued in favour of decorating buildings in the capital with some form of artwork, up to a cost of $2 \%$ of the total sum (decree no. 41.240/1929). This was confirmed in 1941 with a new decree issued by the mayor: Fóvárosi Közlöny 1941, 427.

344 See the preceding footnote.

345 Tér és Forma 14. 1941. No. 4. 65.

346 VÁRKONYI 1947.

347 FISCHER 1942, 107

348 LUCIE-SMITH 2000, 251-253; KIESLER 1936

349 WiLK (ed.) 2006, 18; GORDON 2008, 107-117.

350 Exh. Cat. London 1997, 51.

${ }^{351}$ BFL, Budapesti Mủemléki Felügyelőség irattára: Budapest Fôváros Tanácsa Végrehajtó Bizottságának Múemlékfelügyelőség Fóosztálya levele, Budapest, 1984. szeptember 11. The conservation works were carried out in accordance with a decree (no. II. 2277-3/983) issued by the Technical Department of the Executive Committee of the Council of the 11th District.

$352 \mathrm{BFL}$, Budapesti Múemléki Felügyelôség irattára: Fóváros Tanácsa V. B. 925/74. sz. határozata.

353 BFL, Budapesti Múemléki Felügyelőség irattára: Budapest Fôváros Tanácsa Végrehajtó Bizottságának Fóigazgatóságának Mủemlék-felügyelôsége nevében Antal Jánosné Czétényi Piroska osztályvezetô levele, 1984. szeptember 11. Agreement was reached with Péter Zsille, on behalf of the airport, and the requested documentation was returned to the Monuments Inspectorate on 20 December 1984 BFL, Budapesti Múemléki Felügyelőség irattára: Budapest Fôváros Tanácsa Végrehajtó Bizottságának Főigazgatósága, Múemlék-felügyelósége nevében Antal Jánosné Czétényi Piroska osztályvezetô levele, 1984. december 20.

${ }^{354}$ BFL, Budapesti Múemléki Felügyelőség irattára: Budapest Fôváros Tanácsa Végrehajtó Bizottságának Fóigazgatósága, Mủemlék-felügyelősége nevében Antal Jánosné Czétényi Piroska osztályvezetô levele, 1985. március 12.

355 RÉV 1988, 522-523; HeRCZEG 1982, 14-23; TAKÁTS 2007, 44-46, CSENGEL-Plank 2011, 310-311.

${ }^{356}$ Due to flooding of the runway, the airport's operations had to be suspended in September 1937 in order to install an effective drainage system. Air traffic was returned to the airport in Mátyásföld. Members of the municipal public administration committee regarded this suspension as a serious failure and as vindication of their earlier criticism. They also regarded the drainage system as unworkable, because they were sure it would be destroyed by the weight of the aeroplanes: Fôvárosi Közlöny 1937. No 70, december 28., 2101-2102.

357 FEHÉRVÁRI-PRAKFALVI 2006.

358 JONGE 1991.

359 The terminal building and the large hangar were granted monument status in 2000, while the entire airport complex was granted monument status in 2005

360 EDWARDS-HART (eds) 2004. 
